Zentrum

Für Biodiversität und Nachhaltige Landnutzung

Sektion

Biodiversität, Ökologie und Naturschutz

-Center of Biodiversity and Sustainable Land Use-

Section: Biodiversity, Ecology and Nature Conservation

\title{
Indonesian coastal wetlands
}

The past dynamics of environment and carbon, the potential for climate change mitigation and the assessment for conservation, management and restoration

\author{
Dissertation \\ for the award of the degree \\ "Doctor of Philosophy" (Ph.D. Division of Mathematics and Natural Science \\ of the Georg-August-University of Göttingen
}

within the doctoral program Biodiversity, Ecology and Evolution

submitted by

Kartika Anggi Hapsari

from Purwokerto (Indonesia)

Göttingen, 2018 


\section{Thesis committee}

Prof. Dr. Hermann Behling

(Department of Palynology and Climate Dynamics / Albrecht-von-Haller Institute for Plant Sciences)

Prof. Dr. Erwin Bergmeier

(Department of Vegetation and Pyhtodiversity Analysis / Albrecht-von-Haller Institute for Plant Sciences)

PD. Dr. Tim Jennerjahn

(Department of Biogeochemistry and Geology / Leibniz Center for Tropical Marine Ecology (ZMT) - Bremen)

\section{Members of the examination committee}

Prof. Dr. Hermann Behling

(Department of Palynology and Climate Dynamics / Albrecht-von-Haller Institute for Plant Sciences)

Prof. Dr. Erwin Bergmeier

(Department of Vegetation and Pyhtodiversity Analysis / Albrecht-von-Haller Institute for Plant Sciences)

PD. Dr. Tim Jennerjahn

(Department of Biogeochemistry and Geology / Leibniz Center for Tropical Marine Ecology (ZMT) - Bremen)

Prof. Dr. Markus Hauck

(Department of Plant Ecology / Albrecht-von-Haller Institute for Plant Sciences)

Prof. Dr. Alexander Schmidt

(Department of Geobiology / Evolution of Landplants \& Development of Terrestrial Ecosystem)

Dr. Thomas Giesecke

(Department of Palynology and Climate Dynamics / Albrecht-von-Haller Institute for Plant Sciences)

Date of oral examination: 19.03.2018 
To the pretty face my eyes stuck on 


\section{Content}

Acknowledgements .................................................................................................................. vii

Summary

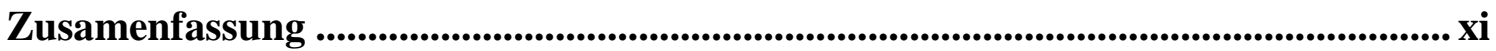

Introduction ................................................................................................................................................. 1

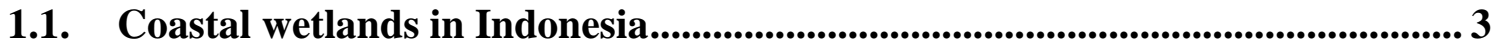

1.1.1. Characteristics and classification............................................................... 3

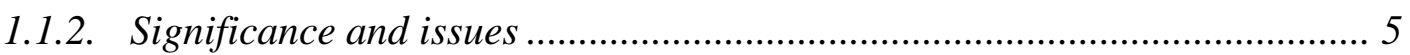

1.1.3. Conservation, management and restoration of Indonesian wetlands........... 8

1.2. Aims and objectives ............................................................................................................... 10

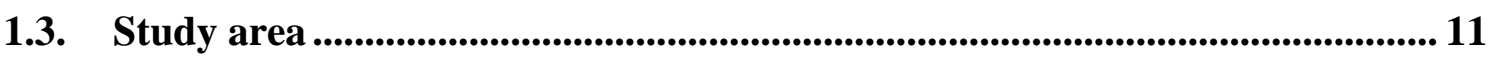

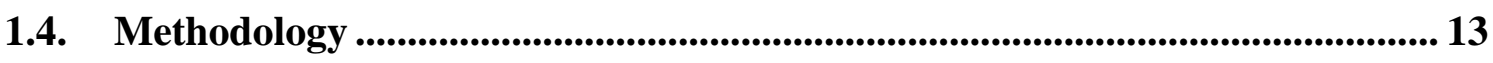

1.4.1. Core sample source ................................................................................ 13

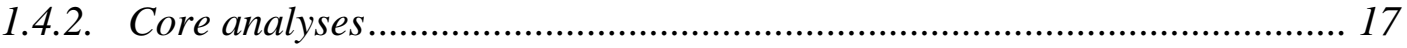

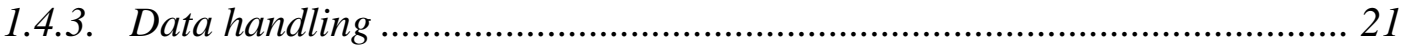

1.5. Outline and content of the chapters ..................................................................... 22

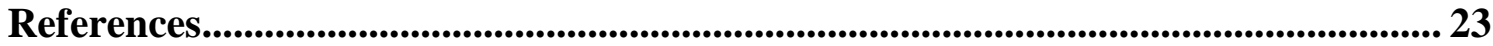

Environmental dynamics and carbon accumulation rate of a tropical peatland in

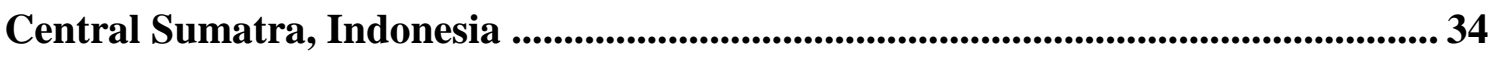

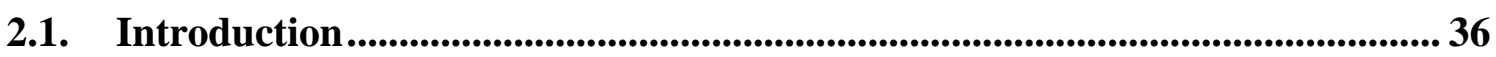

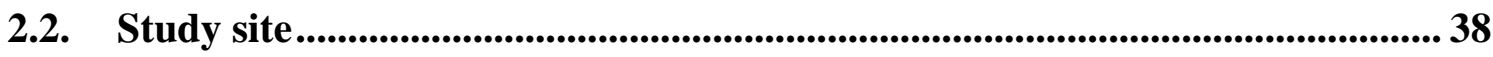

2.3. Material and methods ............................................................................................. 40

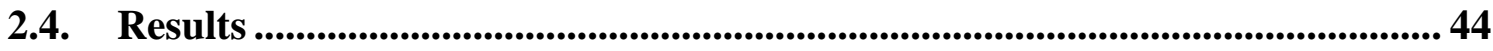

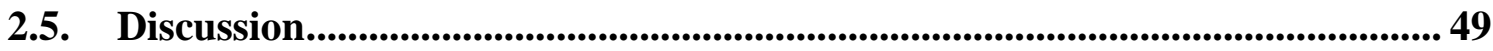

2.5.1. The dynamics of peatland and carbon accumulation rate ......................... 49

2.5.2. Factors controlling $C$ accumulation rate................................................ 56

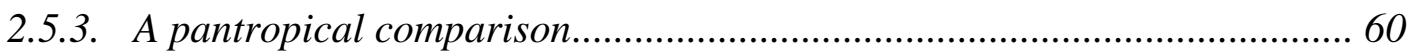

2.6. Summary and conclusion ...............................................................................65 65

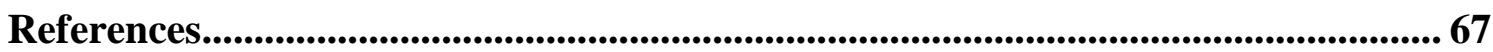

Supplementary 1 ................................................................................................................................ 77

Supplementary 2 ......................................................................................................................... 78

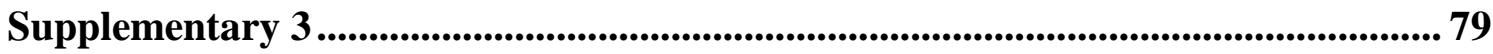


Resilience of a peatland in Central Sumatra, Indonesia to past anthropogenic disturbance: improving conservation and restoration designs using palaeoecology 81

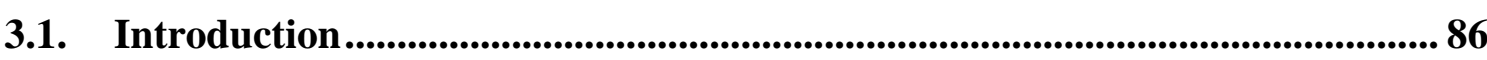

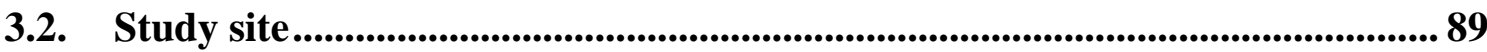

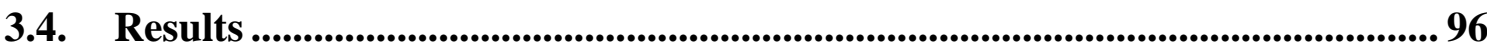

3.4. Discussion........................................................................................................................ 101

3.4.1. Human activities and their impacts on peatland .................................... 101

3.4.2. Peatland response to human disturbance ................................................. 106

3.5. Implication for tropical peatland conservation and restoration .................. 111

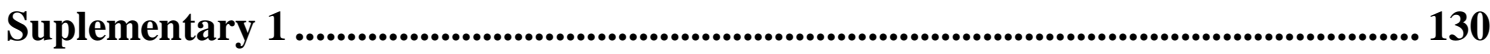

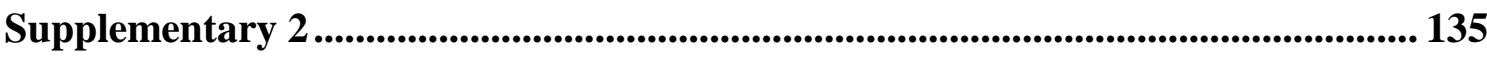

Climate and land use change governed environmental dynamics and carbon accumulation in the mangrove-fringed Segara Anakan lagoon, Java, Indonesia in the Anthropocene and beyond .......................................................................... 137

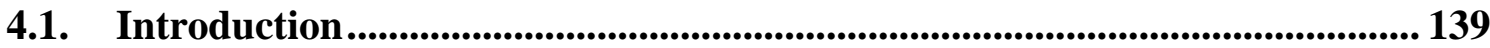

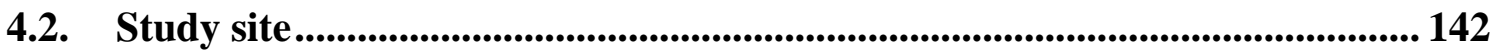

4.3. Materials and methods ................................................................................................ 146

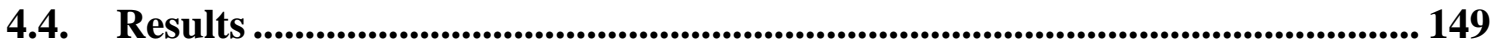

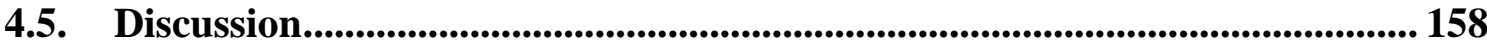

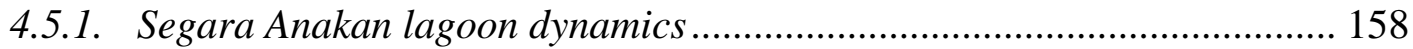

4.5.2. Carbon sequestration in the Segara Anakan Lagoon ............................. 165

4.6. Conclusion................................................................................................................ 169

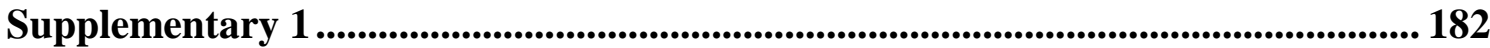

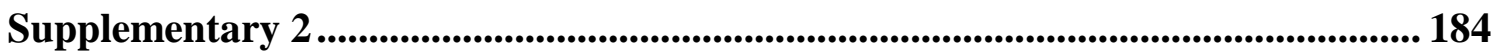

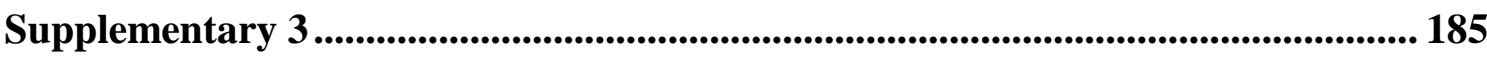

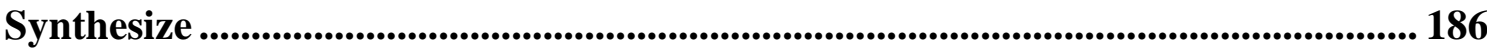

5.1. Environmental and $C$ accumulation dynamics of coastal wetlands in

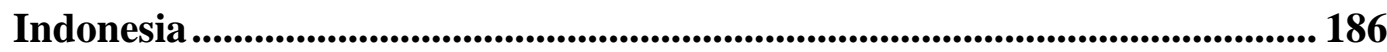

5.2. Potential of Indonesian coastal wetlands for climate change mitigation ..... 187

5.3. Resilience of Indonesian coastal wetlands to disturbances .......................... 189

5.4. Implications for conservation, management and restoration of coastal wetlands in Indonesia........................................................................................... 190

5.5. Future challenges ............................................................................................. 194 


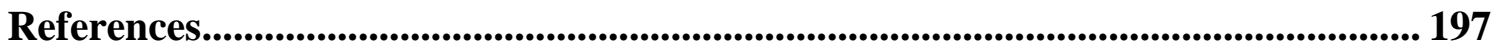

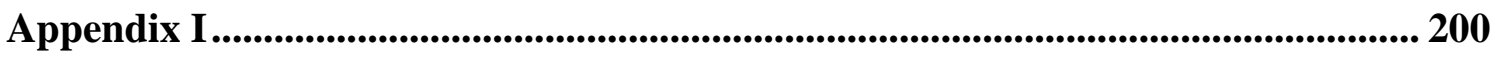

Appendix II ........................................................................................................................... 203

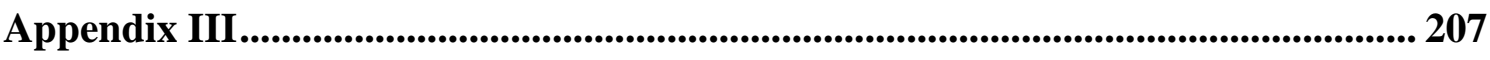

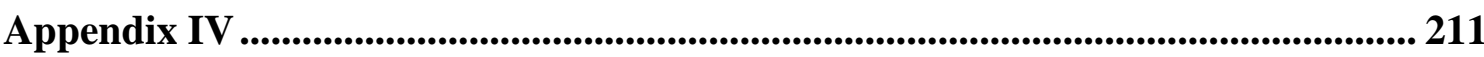




\section{Acknowledgements}

I would like to send my endless gratitude to Prof. Hermann Behling for his patience and guidance through my $\mathrm{PhD}$ work as for being very compassionate all around the clock. I thank Dr. Tim Jennerjahn, PD. for his iron fists that twisted, bent, stretched, and shaped me till I meet my current form. I also thank Prof. Erwin Bergmeier for his supports and glowing recommendations that help me through every single evaluation.

I would like to thank the Erasmus Mundus, DAAD, SPICE Project, CRC - Efforts Project for the financial supports provided throughout my PhD. I thank Dr. Volker Karius for providing me his expertise in ${ }^{210} \mathrm{~Pb}$ dating. I would also like to thank Sabine Stahl and Jörn Profe who helped me dealing with XRF data and Peter Reimer for his help in collecting charcoal data and improving my English.

Very special thanks to Dr. Siria Biagioni for all her supports and companions, personally and scientifically. To Dr. Jörg Chritiansen, thank you so much for bringing orders to my chaos(es), technologically and bureaucratically. I also thank all my colleagues at the Department of Palynology and Climate Dynamics for their supports. To my beer white russian-buddies Lyudmila, Carolina and Vincent, bottoms up!

I would like to send bunch of hugs and kisses to Dr. Sonia Fontana and Dr. Thomas Giesecke for their scientific advices and for lighting up my time in this Department. My whole-hearted love goes to Paula Rodriguez whose cares and supports know no bound...

I would like to thank Dion Pramutadi, whose supports brought me exactly where I am now. I also thank Pristia, Trias, Mega, Hegar and Wahyu for their friendships. My special thanks go to Ucil for his nice companion. I thank my former flat mates Isa, Max and Toby for making my adaptation time to this country more fun. I thank the only (medical) doctor I can bear, Mike Egan, for meeting my way of thinking. I also thank Johannes for simply... materializing 
I thank my parents and my brother for all their supports. It is hard to imagine how they managed to resist the temptation to murder me all this time, considering my annoyance level. I also thank my little nephew, Cio, for his cute little smile $;$

Finally, I am grateful to Pete for his supports and companion throughout my $\mathrm{PhD}$ time... 


\section{Summary}

As an archipelago country, Indonesia harbors vast area of coastal wetlands such as mangrove and peatland that stores around $50 \mathrm{Gt}$ carbon (C). Indonesian coastal wetlands are also rich in biodiversity, providing habitats for over 2000 species of flora and fauna. However, coastal wetlands in Indonesia potentially sustain significant loss due to inundation following the upcoming rapid sea level rise in addition to landuse change and conversion following rapid population growth in the coastal areas.

To reduce the impact of sea level rise and to ensure the sustainability of these ecosystems and their important functions, conservation, management and restoration of Indonesian coastal wetlands are necessary to be conducted. As conservation, management and restoration can be costly while sufficient resources are not always available, effective and efficient strategies are required. For this, a thorough ecological understanding is critical. However, current knowledge relating to coastal wetlands in Indonesia remains a large gap. Moreover, thorough ecological understanding is often difficult to gather as some ecosystem processes and their responses to environmental changes often occur after a long period of time. Therefore, long term ecological studies, such as palaeoecology, are required to conduct.

Thereupon, this multi-proxy palaeoecological research that includes was carried out on two Indonesian coastal wetlands, Sungai Buluh peatland in Central Sumatra and Segara Anakan lagoon in Central Java, in order to: (1) improve the insights on the environmental process and dynamics of coastal wetlands in Indonesia as well as the mechanisms and dynamics of their capacity to store $C$; (2) underline their potential for 
climate change mitigation; and (3) provide consideration to improve conservation, management and restoration of coastal wetlands in Indonesia.

This research suggests that Indonesian coastal wetlands and their capacities to sequester $\mathrm{C}$ are very dynamic and mainly influenced by sea level changes, climatic variabilities and human activities. These factors mainly alter the hydrological conditions and vegetation composition of the coastal wetlands, although the impacts can be sitespecific. Coastal wetlands in Indonesia also have high potential for global climate change mitigation for they have considerable capacities to accumulate $\mathrm{C}$ compared to similar ecosystems globally. Additionally, Indonesian coastal wetlands have shown resilience to past disturbances, both natural and anthropogenic.

Based on the outcomes, some considerations to improve coastal wetlands conservation, management and restoration are provided. This includes (1) setting up priorities or classifying the importance of species, ecosystems, areas, or actions, in order to help solving the most critical problems, optimizing the efforts and allocating the resource; (2) incorporating socioeconomic needs in conservation and sustainable use; (3) selecting effective and efficient restoration approach; and (4) evaluating policy design and implementation. 


\section{Zusamenfassung}

Als ein Archipel-Land beherbergt Indonesien ein großes Gebiet von Küstenfeuchtgebieten wie Mangroven und Torfmoore, die etwa 50 Gt Kohlenstoff (C) speichern. Indonesische Küstenfeuchtgebiete sind auch reich an biologischer Vielfalt und bieten Lebensraum für mehr als 2000 Arten von Flora und Fauna. Die Küstenfeuchtgebiete in Indonesien könnten jedoch aufgrund des bevorstehenden schnellen Anstiegs des Meeresspiegels zusätzlich zu Landnutzungsänderungen und umstellungen infolge des rapiden Bevölkerungswachstums in den Küstengebieten erhebliche Verluste aufgrund von Überschwemmungen erleiden.

Um die Auswirkungen des Meeresspiegelanstiegs zu verringern und die Nachhaltigkeit dieser Ökosysteme und ihrer wichtigen Funktionen zu gewährleisten, müssen die indonesischen Küstenfeuchtgebiete geschützt, bewirtschaftet und wiederhergestellt werden. Da Konservierung, Management und Wiederherstellung kostspielig sein können, während nicht immer genügend Ressourcen zur Verfügung stehen, sind wirksame und effiziente Strategien erforderlich. Dafür ist ein gründliches ökologisches Verständnis von entscheidender Bedeutung. Das derzeitige Wissen über Küstenfeuchtgebiete in Indonesien bleibt jedoch eine große Lücke. Darüber hinaus ist ein gründliches ökologisches Verständnis oft schwierig $\mathrm{zu}$ erfassen, da einige Ökosystemprozesse und ihre Reaktionen auf Umweltveränderungen oft nach langer Zeit auftreten. Daher sind langfristige ökologische Studien, wie Paläoökologie, erforderlich. Daraufhin wurde diese paläoökologische Multi-Proxy-Forschung an zwei indonesischen Küstenfeuchtgebieten, dem Sungai Buluh-Moor in Zentral-Sumatra und der Lagune Segara Anakan in Zentral-Java durchgeführt, um (1) die Erkenntnisse über den 
Umweltprozess und die Umweltdynamik $\mathrm{zu}$ verbessern Küstenfeuchtgebiete in Indonesien sowie die Mechanismen und Dynamiken ihrer Fähigkeit, C zu lagern; (2) unterstreichen ihr Potenzial zur Eindämmung des Klimawandels; und (3) Überlegungen zur Verbesserung der Erhaltung, Bewirtschaftung und Wiederherstellung von Küstenfeuchtgebieten in Indonesien anzustellen.

Diese Untersuchung legt nahe, dass indonesische Küstenfeuchtgebiete und ihre Fähigkeit, C zu sequestrieren, sehr dynamisch sind und hauptsächlich von Veränderungen des Meeresspiegels, klimatischen Schwankungen und menschlichen Aktivitäten beeinflusst werden. Diese Faktoren verändern hauptsächlich die hydrologischen Bedingungen und die Zusammensetzung der Vegetation der Küstenfeuchtgebiete, obwohl die Auswirkungen ortsspezifisch sein können. Küstenfeuchtgebiete in Indonesien haben auch ein hohes Potenzial für eine globale Minderung des Klimawandels, da sie über beträchtliche Kapazitäten zur Akkumulation von C im Vergleich zu ähnlichen Ökosystemen weltweit verfügen. Darüber hinaus haben die indonesischen Küstenfeuchtgebiete Widerstandsfähigkeit gegenüber natürlichen und anthropogenen Störungen gezeigt.

Auf der Grundlage der Ergebnisse werden einige Überlegungen zur Verbesserung der Erhaltung, Bewirtschaftung und Wiederherstellung von Küstenfeuchtgebieten vorgelegt. Dazu gehören (1) die Festlegung von Prioritäten oder die Klassifizierung der Bedeutung von Arten, Ökosystemen, Gebieten oder Maßnahmen, um zur Lösung der kritischsten Probleme beizutragen, die Bemühungen zu optimieren und die Ressourcen zuzuweisen; (2) Einbeziehung sozioökonomischer Bedürfnisse in die Erhaltung und nachhaltige Nutzung; (3) Auswahl eines effektiven und effizienten Wiederherstellungskonzepts; und (4) Bewertung des Politikentwurfs und der Umsetzung. 


\section{Chapter 1}

\section{Introduction}

Wetlands are multiple-value ecosystems that hold ecological, social and economic importance such as flood control, biodiversity and natural resource provisioning, water regulation and quality protection as well as education and recreational purposes (Boavida, 1999; Mitsch and Gosselink, 2000; Zedler and Kercher, 2005; Crooks et al., 2011). However, their unfortunate reputation for being gloomy, source of diseases, harbor of mosquitos and dangerous animals, etc. has guided the society to undervalue wetlands for centuries (Giblett, 1996; Boavida, 1999; Friess, 2016). For those disservices, wetlands are often regarded as waste lands (Ramsar Convention, 1982).

Globally, wetlands cover an estimated area of 5800 to 12800 Mha (Ramsar Convention, 1982; Matthews and Fung, 1987; Finlayson et al., 1999; Zedler and Kercher, 2005). Due to the flooded or saturated condition of these ecosystems which imped the decay process of organic matter $(\mathrm{OM})$, wetlands also play important role in carbon $(\mathrm{C})$ cycle by storing around $500 \mathrm{Gt} \mathrm{C}$ or one-third of total terrestrial soil C (Boavida, 1999; Mitra et al., 2003; Crooks et al., 2011; Keller, 2011). Following the growing population and economy, around half of the total global wetland coverage is estimated to be lost (Zedler and Kercher, 2005), although a more realistic estimation cannot be made owing to lack of documentation in the past (Boavida, 1999). These ecosystems were drained to meet the suitable criteria for agriculture, settlements or industrial purposes while disregarding their ecosystem services and values (Zedler and Kercher, 2005; Crooks et al., 2011). 


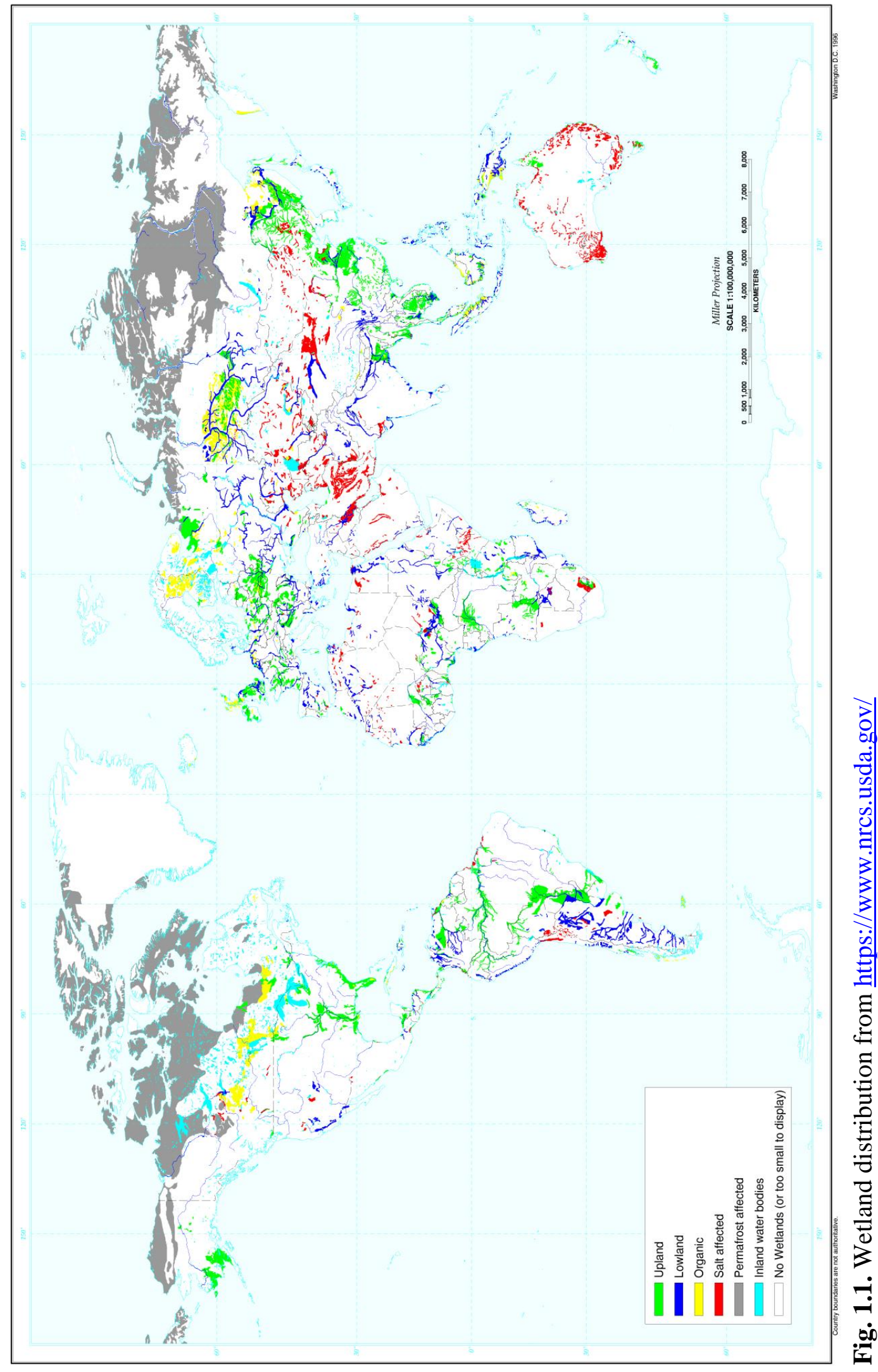


A large proportion of global wetlands are distributed in the coastal areas that are vulnerable to impacts from sea level rise (SLR; Fig. 1.1; Webb et al., 2013). Predicted to rise $3.4 \mathrm{~m}$ per century and significantly accelerate due to the warming climate and ice melt (Nerem et al., 2010; Nicholls and Cazenave, 2010; Rahmstorf, 2010), SLR potentially destroys up to $20 \%$ of global coastal wetlands by the 2080s (Nicholls, 2004). This risk is increased by the growing population in the coastal areas that cause coastal ecosystem degradation around 1\% per year (Zedler and Kercher, 2005). Such loss of coastal wetlands will cause devastating consequences such as carbon emissions and increased risk of storm events (Nicholls and Tol, 2006).

With over $80,000 \mathrm{~km}$-long coastal line, Indonesia is projected to be the most vulnerable country to SRL (Mcleod et al., 2010; Measey, 2010; Zikra et al., 2015). A model with an assumption the rate of SLR is less than $1 \mathrm{~cm}$ per year predict that Indonesia will lose around 2 Mha of its coastal wetlands by 2100 (Mcleod et al., 2010). Such loss will lead to a casualty of over US\$ 600 million that can increase by a factor of three if any adaptation or mitigation is not taken (Mcleod et al., 2010), without taking into account the values of ecosystem services that, in fact, beyond estimation (Boavida, 1999). Moreover, the damage on Indonesian coastal wetlands will also threaten around $50 \mathrm{Gt} \mathrm{C}$ stored as mangrove, seagrass and, mostly, peatland (Keller, 2011; Page et al., 2011; Alongi et al., 2016).

\subsection{Coastal wetlands in Indonesia}

\subsubsection{Characteristics and classification}

Wetlands are commonly defined as transitional zones between terrestrial and aquatic systems (Cowardin et al., 1979; Boavida, 1999; Margono et al., 2014a). It is also defined as the areas "where water is the primary factors controlling the environment and 
the associated plant and animal life" (Niering, 1985). These ecosystems are commonly characterized by their inundated lands or their high water table which are usually at or close to the surface (Cowardin et al., 1979; Margono et al., 2014a).

According to the Committee on Characterization of Wetlands (1995), wetlands have three main characterizations on the water, substrate and vegetation. To be classified as wetlands, an ecosystem needs to be inundated above the upper root layer for at least 15 days during the growing season in most years. Most wetlands also have hydric soil substrates which are saturated and lack of oxygen. Due to their saturated and low oxygen condition, many plants cannot tolerate and adapt, leaving the hydrophytic plants to occupy these ecosystems (Committee on Characterization of Wetlands, 1995). Despite of the common description of wetlands, an ecosystem cannot be classified as wetland if one amongst the three main characteristics, particularly of its hydrological criteria, is not fulfilled (Committee on Characterization of Wetlands, 1995; Boavida, 1999).

In regards to their water chemistry, wetlands can be classified as saline/brackish water and freshwater wetlands (Warner and Rubec, 1997). Saline/brackish water wetlands are the wetland ecosystems which hydrology contains dissolved salt (sodium), which are sourced or influenced from sea water, salt spray and/or inland saltwater (Warner and Rubec, 1997). On the other hand, freshwater wetlands receive very little or no dissolved salt and can further classified as minerotrophic and ombrothopic in respect of the water source (Warner and Rubec, 1997). Minerotrophic wetlands receive the influence of groundwater which usually contain dissolved minerals such as calcium, magnesium and sodium, whereas the hydrology of ombrotrophic wetlands is influenced exclusively 
from precipitation which contain low or no dissolved mineral (Warner and Rubec, 1997).

In Indonesia saline/brackish water coastal wetlands covered an approximate area 60 Mha, mainly of mangrove and seagrass (Alongi et al., 2016). In contrast, the coverage of Indonesian freshwater coastal wetlands is around 20 Mha, consist mainly of ombrotrophic peatland (Page et al, 2011; Osaki et al., 2016). These ecosystems are distributed mostly on the coastal area of Kalimantan, Sumatra, Papua and Java with the share of 30.8, 30.1, 29.9 and $4.7 \%$, respectively (Fig. 1.2; Margono et al., 2014a).

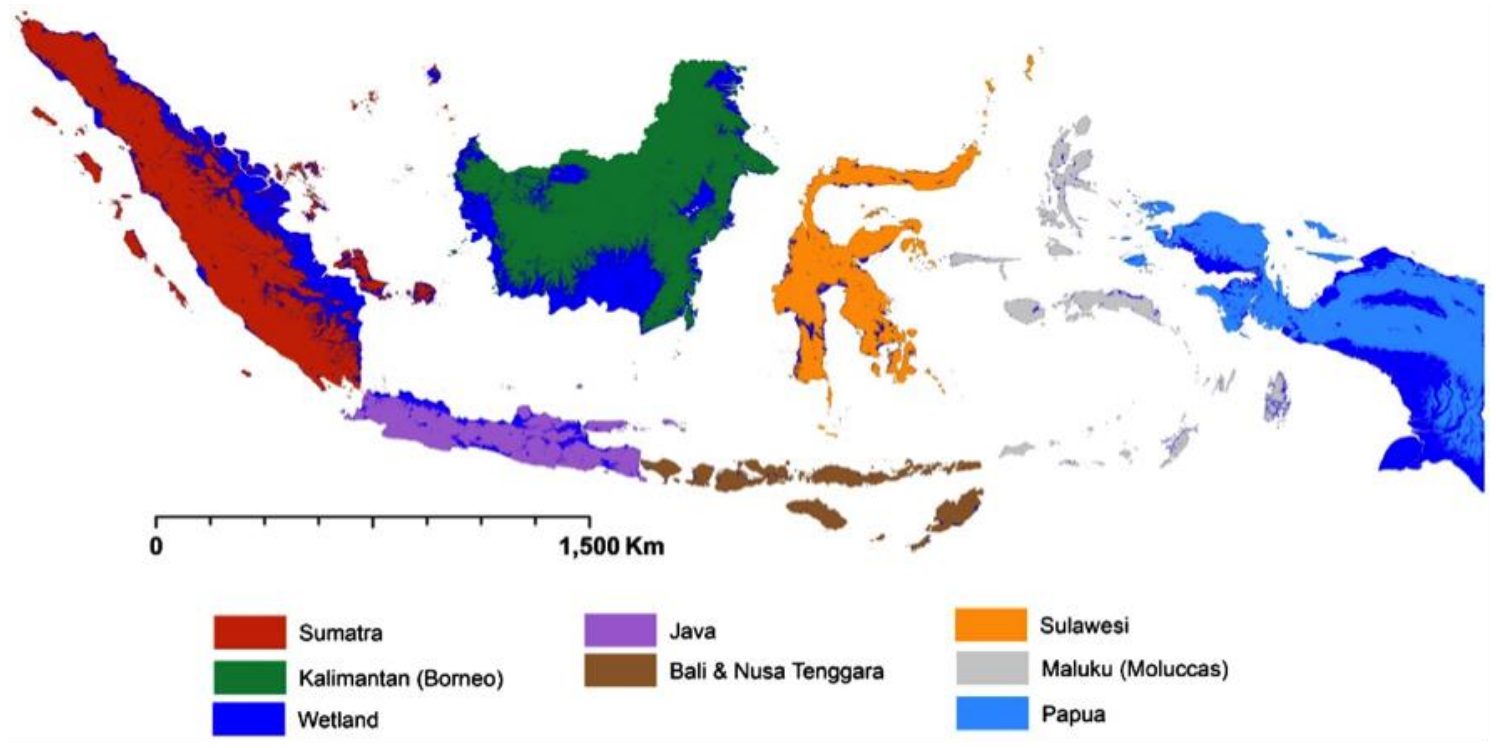

Fig. 1.2. Wetland distribution in Indonesia (Margono et al., 2014a)

\subsubsection{Significance and issues}

Indonesian coastal wetlands are very complex and dynamics ecosystems that play a significant role in global carbon cycle (Donato et al., 2011; Page et al., 2011; Alongi et al., 2016). Around $10 \%$ of total global peat carbon pool is stored mainly in the coastal area of Indonesia (Page et al., 2011; Yu et al., 2011). Moreover, Indonesian mangrove and seagrass ecosystems hold around $17 \%$ of global blue carbon reservoir (Alongi et al., 2016). Despite of their importance, the information regarding $\mathrm{C}$ sequestration in 
Indonesian coastal wetlands remains a large gap (Page et al., 2004; Dommain et al., 2011; Donato et al., 2011). Although a large C proportion (49-98\%) of the Indonesian coastal wetlands are stored as belowground C (Donato et al., 2011), information regarding belowground $\mathrm{C}$ of coastal wetlands in Indonesia is limited. As a consequence, the more realistic number of $\mathrm{C}$ storage in Indonesia cannot be made and the understanding on the factors controlling the C dynamics is sparse (Page et al., 2004; Dommain et al., 2011; Donato et al., 2011; Charman et al., 2013).

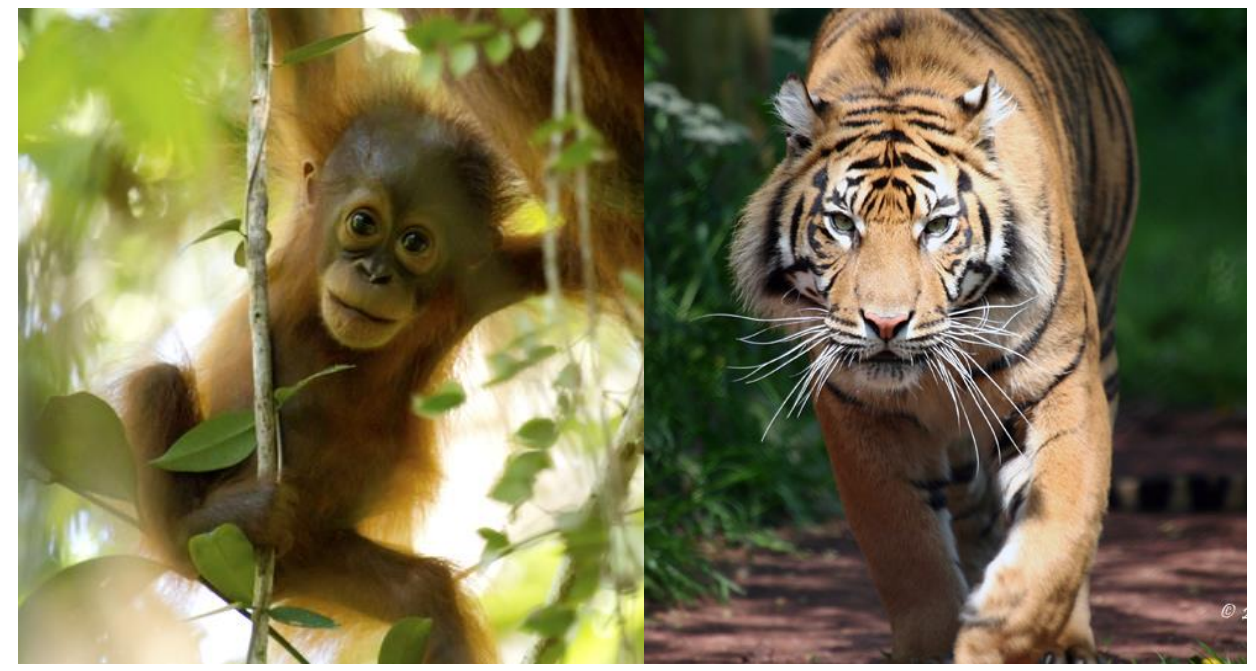

Fig. 1.3. Critically endangered species that inhabit Indonesian coatal wetlands: Orangutan (left; courtesy of Borneo Nature Foundation, 2017) and Sumatran tiger (right; courtesy of Jonathan Carre, 2008)

Indonesian coastal wetlands are also important mainly for their biodiversity provisioning (Sukarjo, 2004; Hutomo and Moosa, 2005; Polidoro et al., 2010; Posa et al., 2011). More than 2000 species of flora and fauna are recorder from Indonesian wetlands, although due to limited studies conducted, this number could be underestimated (Hutomo and Moosa, 2005; Posa et al., 2011). According to IUCN red list (www.iucnredlist.org/), some of these species such as Bruguiera hainesii (mangrove tree; Polidoro et al., 2010; Ono et al., 2016), Betta persephone, B. miniopinna and B. spilotogena (fishes; Posa et al., 2011) are critically endangered. Whereas some other 
species are listed as endangered, such as orangutan (Pongo sp.; Fig. 1.3), Sumatran tiger (Panthera tigris sumatrae; Fig. 1.3), proboscis monkey (Nasalis larvatus), rough-nose stingray (Pastinachus solocirostris) as well as the largest (Rafflesia arnoldi) and the tallest flower (Amorphophallustitanium titanium; www.iucnredlist.org/; Posa et al., 2011). Furthermore, Indonesian wetlands also harbor economically high value species such as ramin trees (Gonystylus bancanus; Posa et al., 2011), red meranti tree (Shorea pauciflora; Soerianegara and Lemmens, 1994), the giant tiger, Indian and banana prawns (Penaeus monodon, P. indicus and P. merguiensis; Sukarjo, 2004) also the giant mud, blue and red-spotted-swimming crabs (Scylla serrata, Neptunus pelagicus and $N$. sanguinolentus; Sukarjo, 2004).

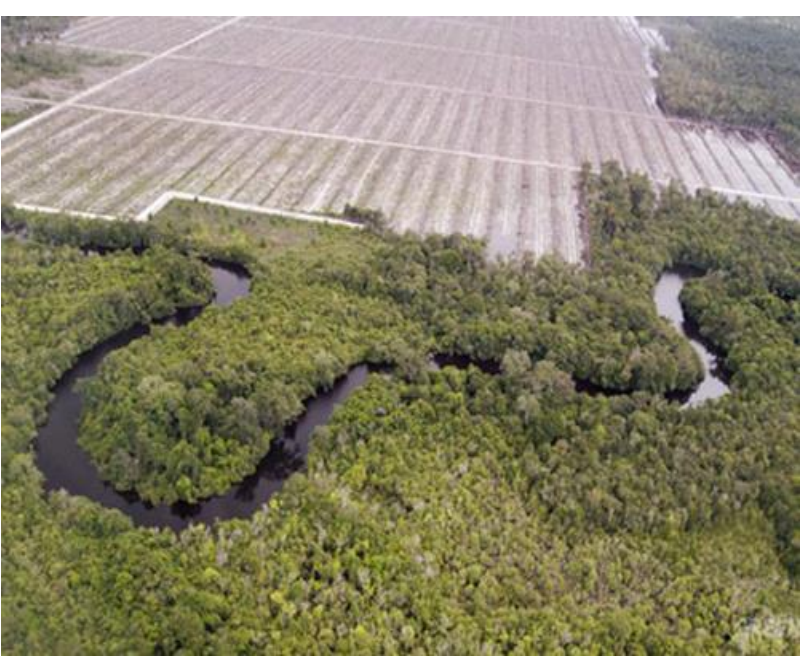

Fig. 1.4. Patches of converted peatland surrounded by unconverted peat-swamp forest (http://www.desdemonadespair.net)
As to other coastal wetlands globally, the current rapidly changing environment also potentially shift the Indonesian wetlands from 'significant carbon sink' to 'enormous carbon source' (Eong, 1993; Li et al., 2007; Page et al., 2011). For instance, ENSO-related fire in 1997 alone has released over 2

Gt peat $\mathrm{C}$ to the atmosphere which is equal to one fourth of global annual fossil fuel emission in 2008 (Page et al., 2002; Le Quéré et al., 2009). Moreover, SLR, which globally predicted to increase around $2 \mathrm{~m}$ per year, potentially jeopardize around $8 \mathrm{Gt} \mathrm{C}$ stored on the lowland coastal tropical peatlands, which are mainly distributed in 
Indonesia (Page et al., 2011; Whittle and Galego-Sala, 2016). In addition, mangrove deforestation released around 0.1 Gt C annually (Siikamäki et al., 2012)

Such risks are further worsened by the growing population and economy of Indonesia (Polidoro et al., 2010; Page and Baird, 2016). Only between 1990 and 2010, the development of palm oil and pulpwood (Acacia) plantation has converted over 8.5 Mha of Indonesian peatland (Jauhiainen et al., 2012; Miettinen et al., 2012; Fig. 1.4). The development of settlements also has reclaimed over 2 Mha of Indonesian mangrove areas during the period of 1982-2010 (Siburian and Haba, 2016). In addition, pollution and over exploitation also increase the stress on Indonesian coastal wetlands (Wong, 2004). This would not only potentially release a significant amount of $C$ to the atmosphere, but also loss of biodiversity provisioning and ecosystem services (Polidoro et al., 2010; Page and Baird, 2016).

\subsubsection{Conservation, management and restoration of Indonesian wetlands}

In regards to the potential risk and threat of rapidly changing climate and ongoing severe human impact, the values and functions of coastal wetlands need to be maintained through conservation, management and restoration (Posa et al., 2011; Murdiyarso et al., 2015; Friess et al., 2016; Page and Baird, 2016). To protect and/or conserve an ecosystem, it is important to understand the values of the ecosystems (Adame et al., 2015; Friess et al., 2016). As often the needs to conserve an ecosystem intersect with socioeconomic interests, such understanding is crucial to strengthen the argument why a protection or conservation is necessary and why the investment for such action needs to be made (Maron et al., 2012; Friess et al., 2016).

In Indonesia, several efforts to conserve, manage and restore coastal wetlands have been widely conducted mainly to maintain and/or restore their $\mathrm{C}$ sink and biodiversity values 
(http://www.katinganproject.com; https://www.adb.org; Sukardi, 2010; van Eijk et al., 2010). There efforts are, however, considered to be ineffective as they failed to deliver the expected outcomes (ADB, 2006; Sukardi, 2010; van Eijk et al., 2010; Dharmawan et al., 2016), mainly due to the fragmented knowledge of the ecosystems and neglect to the socioeconomic as well as cultural aspects (van Eijk et al., 2010; Dharmawan et al., 2016).

Protected or conserved areas are often considered as "biological success and social failures" as they give positive ecological impacts but contradictory socioeconomic outcomes (Christie, 2004). This causes conflicts and tensions between local population and practitioners that consequently lead to non-cooperation, legal challenge, sabotage and even criminality (Holmes, 2013). The situation is worsened by the weak national policies for conservation and restoration (Friess et al., 2016). Lack of awareness and interests from both society and policy makers might also be responsible for the ineffectiveness of conservation and restoration efforts (Villa et al., 2014).

As the available resources are often limited, effectiveness, efficiency and accuracy of conservation, management and restoration programs are very pivotal (Rey Benayas et al., 2008; Graham et al., 2013; Adame et al., 2015; Friess et al., 2016). Adequate information of the target ecosystems such as the ecological process and their driving factors are therefore required to reach and improve the effectiveness, efficiency and accuracy of conservation and management practices (Webb et al., 2013; Adame et al., 2015; Dharmawan et al., 2016). Moreover, thorough ecological understanding is very useful to create better conservation and management strategies by identifying the risks and consequences of actions taken to the ecosystems and/or their values, as well as 
assessing the future ecosystem fates in regards to environmental changes such as warming climate or SLR (Birks, 2012; Webb et al., 2013).

Such information is, however, often difficult to gathered as some ecosystem processes and their responses to environmental changes occur only after a long period of time (Willis and Birks, 2006; Birks, 2012). Palaeoecology, or also known as long term ecology, can offer the solution to the temporal limitation of ecological perspective (Davies, 2007; Davies and Bunting, 2010; Bhagwat et al., 2011; Birks, 2012; Page and Baird, 2016). Extending from years to millions of years, palaeoecology can provide long temporal series of ecological records (Seppä, 2009).

Nowadays, the needs for palaeoecological information to improve ecosystem conservation and management are widely recognized (Jackson and Hobbs, 2009; Lyver et al., 2015; McCarrol et al., 2017; Nogué et al., 2017). In the Northland region, New Zealand, for instance, palaeoecological studies have informed the conservation practitioners that active restoration is necessary as the ecosystem is no longer able to naturally regenerate (Lyver et al., 2015). However, in Indonesia, the importance of palaeoecology for ecosystem conservation, management and restoration is barely acknowledged. Also, the available palaeoecological information in Indonesia is very limited (Dommain et al., 2011; Biagioni et al., 2015). Additionally, studies that integrate palaeoecological information and the ecosystem values such as $\mathrm{C}$ storage capacity are very sparse (Dommain et al., 2011).

\subsection{Aims and objectives}

This research aims to understand the environmental process and dynamics of coastal wetlands in Indonesia as well as the mechanisms and dynamics of their capacity to store 
C. This research also intends to underline their potential for climate change mitigation. These above aims raise the following research objectives:

- To identify the driver of environmental changes in Indonesian coastal wetlands

- To identify the factors controlling $\mathrm{C}$ accumulation of Indonesian coastal wetland

- To acknowledge how significant the $\mathrm{C}$ sequestration of Indonesian coastal wetlands amongst other similar ecosystem globally

The outcomes of this research are purposed to provide considerations to improve conservation, management and restoration of coastal wetlands in Indonesia which raise the additional following objectives:

- To assess the resilience of Indonesian coastal wetlands to disturbances, both natural and anthropogenic

- To create an implication to enhance the effectiveness, efficiency and accuracy of conservation, management and restoration of coastal wetlands in Indonesia

\subsection{Study area}

Indonesia is the largest archipelago country in the world covering around 790 million ha mainly of sea area (Cribb and Ford, 2009). This country consists of over 18000 islands scattering from the islands of Breueh and Sabang on the west to Sibir Island in Teluk Yos Sudarso, Papua (Cribb and Ford, 2009). Kalimantan, Papua, Sumatra, Sulawesi and Java are the largest main islands in Indonesia (Cribb and Ford, 2009).

The climate of Indonesia is tropical with very high humidity and moderate temperature (Syaukat, 2011). The rainfall variabilities in Indonesia are strongly influenced by the El Niño-Southern Oscillation (ENSO; Aldrian and Susanto, 2003) and the Indian Ocean Dipole (IOD; Saji et al., 1999; Fig. 1.5). ENSO is a variation of sea surface temperature (SST) and wind across the Pacific Ocean that results in changes in rising or descending 
moisture depending on the region (Philander, 1983). ENSO consists of two different climatic phases: El Niño and La Niña (Philander, 1983). During the period of El Niño warm-phase, Indonesia experiences lower rainfall variability than usual years, whereas La Niña cold-phase led to the higher rainfall (Philander, 1990). Similar to ENSO, IOD is a fluctuation of SST and wind across the Indian Ocean that is also differentiated into two phases: negative and positive (Saji et al., 1999). During negative IOD phases, the sea surface temperature in the western Indian Ocean is anomalously low while the eastern part is warmer than usual, resulting in an increase in precipitation over western Indonesia (Saji et al., 1999; Niedermeyer et al., 2014).

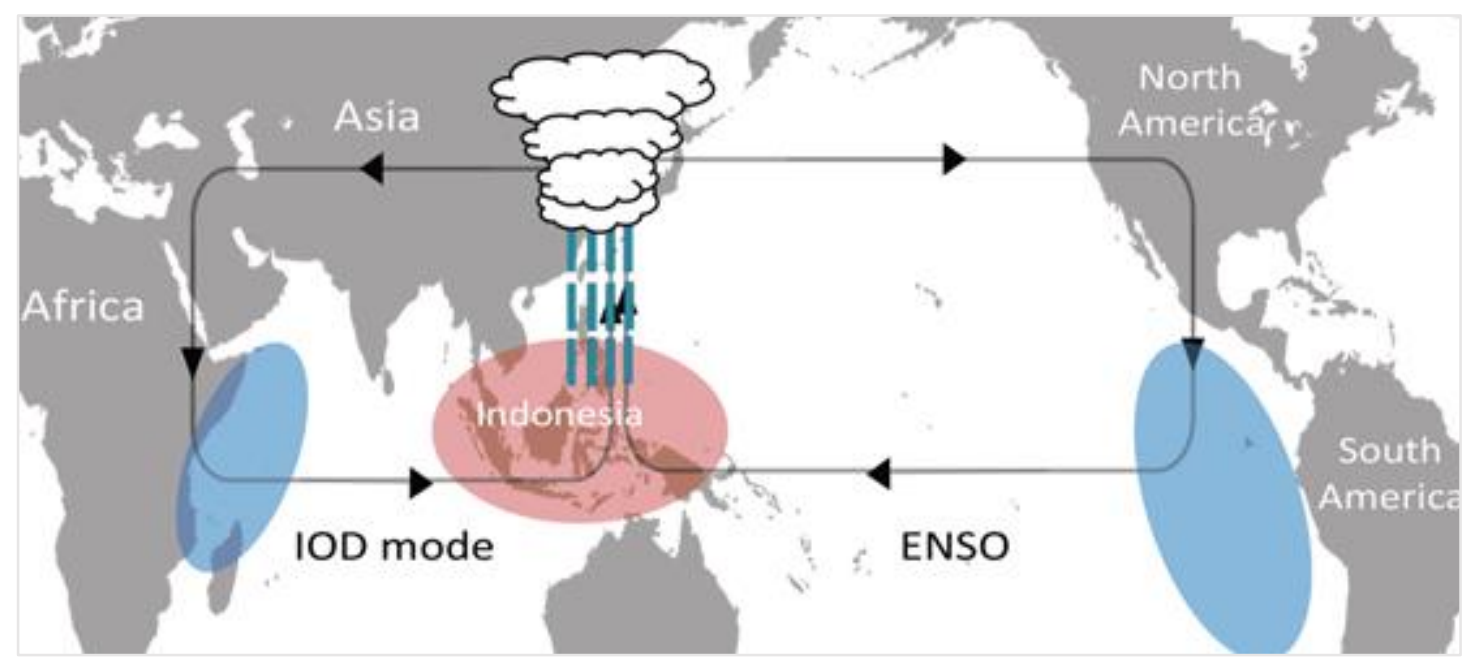

Fig. 1.5. Simplified atmospheric circulation of Indonesian climate (courtesy of Eva Niedermeyer)

Indonesia is also one amongst the most populated country in the world with more than 260 million inhabitants (The World Bank, 2016; http://databank.worldbank.org/) concentrated mostly in Java and Sumatra (Cribb and Ford, 2009). More than 50\% Indonesian population lives in Java (Statistik Pekerjaan Umum, 2013). Sumatra, on the other hand, is inhabited by around $24 \%$ of Indonesian population, that are mostly comes from Java as a result of transmigration program conducted by Indonesian government in 1970s (Statistik Pekerjaan Umum, 2013). 
Being the most populous islands in Indonesia, Java and Sumatra suffer from very severe human impact (Agus et al., 2004; van Dijk et al., 2004; Margono et al., 2014b). With a long history of human occupation and settlements, Java has subjected for a long deforestation and degradation since the $19^{\text {th }}$ centuries (Boomgard, 1992; Olson and Berry, 2004). Nowadays only less than $10 \%$ of forest remains in Java (Nijman, 2003). Sumatra, on the other hand, has massively impacted only after the mass migration program in 1970s (Margono et al., 2012). Only between 1990 and 2010, more than 7 Mha of Sumatran forest cover has been lost (Margono et al., 2012). Such loss and the following consequences like erosion and extinction has raised a lot of concerns. Thereupon, numbers of conservation, management and restoration efforts have been conducted in Java and Sumatra, although the outcomes are not very pleasing (Smiet, 1990; Asean US CRMP, 1992; ADB, 2006; Sukardi, 2010; van Eijk et al., 2010; Gunawan et al., 2012).

To meet the aims and objectives of this research, two Indonesian coastal wetlands, Sungai Buluh peatland in Central Sumatra and Segara Anakan lagoon in Central Java are selected. Both wetlands are considered suitable to represent the wetlands that are under suppression of both natural and anthropogenic stressors. Moreover, both wetlands are subjected to conservation, management and restoration practices.

\subsection{Methodology}

\subsubsection{Core sample source}

This research is conducted using two cores taken from the selected coastal wetlands (Fig. 1.6). One peat core $(350 \mathrm{~cm}$; SB-B) was recovered from Sungai Buluh peatland using a Russian Corer (Jowsey, 1966) in 2013. Meanwhile, another sediment core (500 
cm; SA-102) was taken from Segara Anakan lagoon using a 5-cm diameter Livingstone piston corer (Wright, 1967) in 2014.

\section{A. Sungai Buluh peatland}

Sungai Buluh peatland is a protected peat restoration area in Jambi province, Central Sumatra. Located around $19 \mathrm{~km}$ from the coastline, this peatland cover an area of 18000 ha with its elevation ranging between 9 and $25 \mathrm{~m}$ above sea level (asl). As most of Indonesian region, this peatland is covered by tropical humid climate with the mean annual temperature $26^{\circ} \mathrm{C}$. The annual precipitation is $2400 \mathrm{~mm}$ and influenced by ENSO (Aldrian and Susanto, 2003) and IOD (Saji et al., 1999).

Despite of its status as protected restoration area, the overall information regarding this peatland is very limited. The average water table of this peatland is $0.3 \mathrm{~m}$ with a fluctuation ranging from 0 to $0.7 \mathrm{~m}$ below the peat surface (http://space.geocities.jp/hkdkalimantan/jambil/jambilhome.html). The vegetation covering this peatland is currently classified as secondary peat swamp forest (PSF; Melati et al., 2015) while the original forest cover was reduced by ENSO-related fire in 1997 (Tata et al., 2016). This peatland was replanted with highly commercial timber trees Shorea pauciflora and Dyera polyphylla in 2003 following the instructions from the Department of Forestry of the Jambi Province (Nurjanah et al., 2013). The surrounding area of this peatland is converted into agricultural field as well as oil palm and pulp plantation.

Around $28 \mathrm{~km}$ south of this peatland on the banks of Batang Hari River, an ancient Muara Jambi temple complex of Malayu Empire was found. According to the archaeological records, the $12 \mathrm{~km}^{2}$ temple complex was built around the $9^{\text {th }}$ and $14^{\text {th }}$ centuries and functioned as the capital of the empire (Tjoa-Bonatz et al., 2009; 
Witrianto, 2014). Malayu Empire was one of the largest kingdoms in Indonesian history that played significant role in trading particularly forest and animal products from Sumatran hinterland area (Tjoa-Bonatz et al., 2009; Witrianto, 2014).

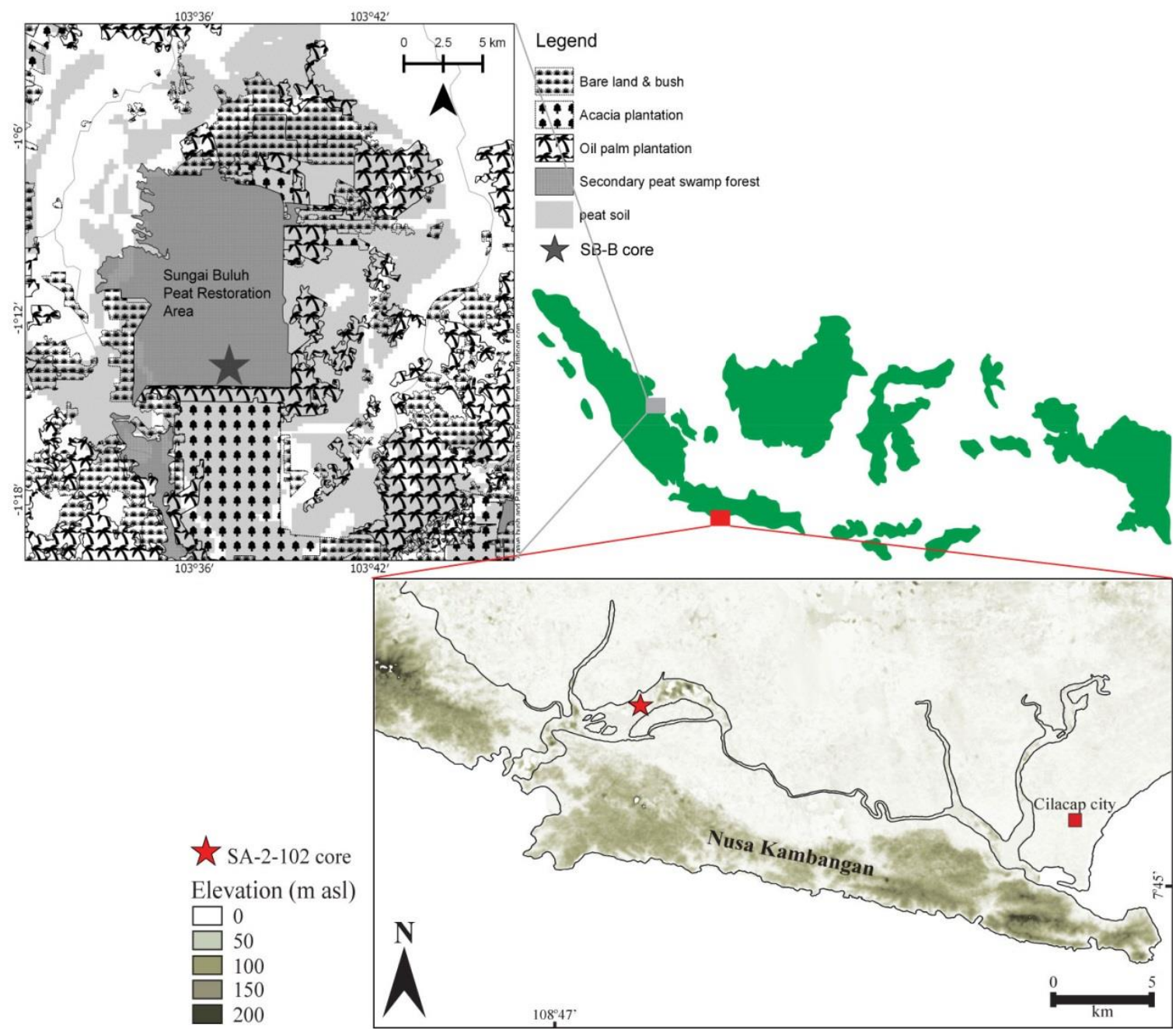

Fig. 1.6. Map of core sources. Grey square represents Sungai Buluh peatland while red square shows the location of Segara Anakan lagoon.

\section{B. Segara Anakan lagoon}

Segara Anakan is a mangrove-fringed lagoon in the southern coast of Java Island. Surrounded by around 9200 ha mangrove forest mainly of Rhizophora apiculata, Avicennia corniculatum, A. alba, Nypa fruticans, Sonneratia caseolaris and Bruguiera gymnorrhiza, Segara Anakan is separated from Indian Ocean by Nusakambangan Island 
(White et al., 1989; Ardli and Wolff, 2009; Hinrichs et al., 2009). Within the lagoon, the tides are semidiurnal with amplitude variation ranges from 0.2 to $2.6 \mathrm{~m}$ (White et al., 1989). Depending on the freshwater input that comes mainly from Cintanduy River and precipitation, the lagoon salinity is ranging from 28 to 1 part per thousand (ppt; White et al., 1989; Noegrahati and Narsito, 2007; Holtermann et al., 2009). As most of Indonesian regions, the climate of this lagoon is tropical humid with mean annual precipitation of $3400 \mathrm{~mm}$ (www.weatherbase.com). The inter-annual rainfall variability of Segara Anakan area is influenced by ENSO (Qian et al., 2010) with a mean annual temperature of $27.2^{\circ} \mathrm{C}$. Only through Citanduy River flow, Segara Anakan receives around $140 \mathrm{~m}^{3} \mathrm{~s}^{-1}$ sediment input (Holtermann et al., 2009). The sediment sourced from a wide catchment area covers around 450,000 ha of Tasikmalaya and Ciamis districts, West Java as well as Cilacap districts, Central Java (Lukas, 2017). This lagoon flows out around $555 \mathrm{~m}^{3} \mathrm{~s}^{-1}$ sediment to the Indian Ocean through the western channel (Holtermann et al., 2009).

Nowadays, SAL is inhabited by ca. 17,300 of "Orang Laut" (Sea People) that are mostly fisherman, farmer and aquaculture farmer who lives in "Kampung Laut" (Sea Village) (Ardli and Wolff, 2009; BPS Cilacap, 2017). The population of Segara Anakan distributed around the area of Ujungalang, Ujunggagak, Klaces and Penikel (BPS Cilacap, 2017; Ardli and Wolff, 2009). This lagoon was subjected for pearling ground by the Dutch India Company in the early $17^{\text {th }}$ century (Máñez, 2010).

Segara Anakan lagoon has been subjected to intensive conservation efforts since 1982 (Asean US CRMP, 1992; ADB, 2006). Mangrove rehabilitation, dam construction, vertical drainage and sediment dredging are attempted mainly to decline rapid sedimentation rate (Sukardi, 2010; Lukas, 2017). However, such efforts failed to 
provide the expected outcome due to inadequate ecological and socioeconomic knowledge (Sukardi, 2010; Dharmawan et al., 2016).

\subsubsection{Core analyses}

\section{A. Core chronologies}

For this research, the chronologies of the cores were developed based on the Accelerator Mass Spectrometry (AMS) ${ }^{14} \mathrm{C}$ and ${ }^{210} \mathrm{~Pb}$ ages. Eleven samples of SB-B core were selected and sent to the AMS-laboratory at the University of Nürnberg/Erlangen, Germany and Poznan Radiocarbon Laboratory, Poland for radiocarbon dating. Meanwhile, three samples of SA-102 were selected and sent to NTUAM AMSLaboratory, Taiwan.

The AMS ${ }^{14} \mathrm{C}$ results of SB-B core suggest that the peat core span from ca. 13,400 cal yr BP to the present. The age-depth model of SB-B is constructed using the SHCal13 calibration curve with Bayesian accumulation model, Bacon (Blaauw and Christen, 2011) script in R (R Core Team, 2014). A robust Student's T analysis (Christen and Pérez, 2009) was applied to identify the outliers prior to the construction of the age depth model.

On the other hand, the AMS ${ }^{14} \mathrm{C}$ results of SA-102 core suggest that the core covers the past 500 years with the top $300 \mathrm{~cm}$ of the core was too young to be dated with $\mathrm{AMS}{ }^{14} \mathrm{C}$ analysis. Thus, the top $270 \mathrm{~cm}$ of SA-102 was analyzed for ${ }^{137} \mathrm{Cs},{ }^{210} \mathrm{~Pb}$ and ${ }^{214} \mathrm{~Pb}$ at the Laboratory for Radioisotopes (ISOLAB) in Göttingen, Germany. To calculate the ${ }^{210} \mathrm{~Pb}$ age of SA-102 core, the constant rate of supply (CRS) model was used (Applebly and Oldfield, 1978; 1983). CRS model is suitable and widely used to calculate ${ }^{210} \mathrm{~Pb}$ age in lakes, coastal zones or estuaries where sedimentation processes are highly influenced by anthropogenic activities (Appleby and Oldfield, 1978; Lubis, 2006). This model is 
applicable for sediment core with non-monotomic ${ }^{210} \mathrm{~Pb}$ profile with an assumption that the flux of excess ${ }^{210} \mathrm{~Pb}$ is constant (Applebly and Oldfield, 1978; 1983; Appleby, 2008). The age depth model of SA-102 was constructing by integrating both AMS ${ }^{14} \mathrm{C}$ and ${ }^{210} \mathrm{~Pb}$ dates using P-sequence depositional model in OxCal v.4.2 (Ramsey, 2009). The detection of outlier was conducted using SSimple model (Christen, 1994) in OxCal prior to the construction of the age depth model.

\section{B. Pollen and spore analysis}

Pollen and spore are reproductive cells produced by angiosperms and gymnosperms (pollen) and sporophyte (spore; Reitz and Shackley, 2012). Unlike other organic material, pollen and spores are resistant to microbial, physical and chemical degradation due to their sporopollenin-wall structures (Brooks and Shaw, 1978). The recalcitrant characteristic of sporopollenin allows the pollen and spore to be preserved on the sediment layer as they are washed or blown from the plant source (Brooks and Shaw, 1978).

Pollen and spore also have unique shapes that allow them to be identified in accordance to their plant source (Goodwin, 1934). The insight on the growing vegetation when the pollen and spore were produced provides an understanding on the environmental and climatic condition (Goodwin, 1934; Prentice, 1988). Thus, the changes in pollen assemblage can be assumed to reflect the changes in vegetation composition as well as in climate and environment (Prentice, 1988).

To assess the change in past vegetation of the study areas, we applied pollen analyses on the core sample by processing the subsamples following the standard pollen and spore extraction methods (Faegri and Iversen, 1989). Prior to the extraction process, Lycopodium spore tablets were added to each subsample. The extracted pollen and 
spores were then counted and identified using the reference collection of pollen and spores of the Department of Palynology and Climate Dynamics, University of Göttingen, and other available literatures (eg. Pollen and Spore Image Database of the University of Goettingen-available at http://gdvh.uni-goettingen.de/; Mao et al., 2012; Li et al., 2012; Cole et al., 2015; Jones and Pearce, 2015).

C. LOI, TC, TN, $\delta^{13} C_{\text {org }}$ and $\delta^{15} N$

Loss-on-ignition (LOI) analysis is a common method to determine the OM content of peat (Wüst et al., 2003). It is conducted by taking peat subsamples and drying the subsamples at $105^{\circ} \mathrm{C}$ for $24 \mathrm{~h}$. Both wet and dry subsamples were weighed. The subsamples were then combusted at $550^{\circ} \mathrm{C}$ for $4 \mathrm{~h}$. The combusted subsamples were also weighed. The OM content of each subsample was calculated using following equation:

$$
O M_{L O I}(\%)=\left(\frac{d r y \text { weight after } 105^{\circ} \mathrm{C}-\text { weight after combustion }}{\text { dryweight after } 105^{\circ} \mathrm{C}}\right) \times 100
$$

In order to trace the change in environmental condition of study areas, total carbon (TC), total nitrogen $(\mathrm{TN})$ and stable isotope composition of organic carbon and nitrogen $\left(\delta^{13} \mathrm{C}_{\text {org }}\right.$ and $\left.\delta^{15} \mathrm{~N}\right)$ are analyzed. TC, TN, $\delta^{13} \mathrm{C}_{\text {org }}$ and $\delta^{15} \mathrm{~N}$ were determined by analyzing core subsamples that were dried at $60^{\circ} \mathrm{C}$, finely ground and weighed. $\mathrm{TC}, \mathrm{TN}$ and $\mathrm{C}_{\text {org }}$ were determined by high temperature of oxidation in a Euro EA3000 elemental analyzer. $1 \mathrm{~N} \mathrm{HCl}$ treatment was applied to remove carbonates, prior the determination of $\delta^{13} \mathrm{C}_{\text {org }}$ and $\delta^{15} \mathrm{~N}$ in a Thermo Finnigan Delta Plus gas isotope ratio mass spectrometer after high temperature combustion in a Flash 1112 EA elemental analyzer. The $\delta^{13} \mathrm{C}_{\text {org }}$ and $\delta^{15} \mathrm{~N}$ is reported as per mil (\%o) deviation from the carbon isotope composition of the Vienna Pee Dee Belemnite (VPDB) with $\pm 0.1 \%$ uncertainty of each measurement. 


\section{Charcoal analysis}

Charcoal particles are produced through incomplete OM combustion (Whitlock and Larsen, 2002). This particle then distributed and deposited in accordance to their size (Whitlock and Larsen, 2002). Due to their lighter weight, smaller particles can reach a greater distribution than the larger ones (Whitlock and Larsen, 2002). Thus, the larger charcoal particles are considered to be more appropriate to reflect the local fire events (Whitlock and Larsen, 2002).

To understand the past local fire regime of the study areas, macro-charcoal analysis was performed. Subsamples were taken continuously from the core and prepared following the method developed by Rhodes (1998) and Stevenson and Haberle (2005). OM in the sediment was removed using weak hydrogen peroxide $\left(6 \% \mathrm{H}_{2} \mathrm{O}_{2}\right)$ and particles $>125$ $\mu \mathrm{m}$ were retained after gentle wet-sieving. All charcoal particles $>150 \mu \mathrm{m}$ were counted under a stereomicroscope and concentrations were calculated as particles $\mathrm{cm}^{-3}$. Fire regime characteristics were identified using CharAnalysis (Higuera et al., 2009).

\section{E. XRF profile}

XRF scanning is a powerful and non-destructive method to trace the variation in elemental and other sediment property of a core (Croudace et al., 2006). In XRF profile, the relative changes of the elements in this profile are of interest for interpretation rather than the absolute values of concentration, as the results are shown as element count per second (cps; Kylander et al., 2011). For this research, the XRF scanning was conducted at GEOPOLAR, University of Bremen using Mo-tube on the ITRAX (CS-8)-XRF scanner (Croudace et al., 2006). Selected elements are reported in the XRF profile. 


\section{F. Carbon accumulation rate}

$\mathrm{C}$ accumulation rates of the study areas were calculated by multiplying core bulk density (BD) with total organic carbon $\left(\mathrm{TC}_{\mathrm{org}}\right)$ and sediment accumulation rate. $\mathrm{C}$ accumulation rates are presented as $\mathrm{g} \mathrm{C} \mathrm{m}^{-2} \mathrm{yr}^{-1}$. BD was calculated by taking core subsamples and subsequently dried at $105^{\circ} \mathrm{C}$ for $24 \mathrm{~h}$. Both wet and dry weights were weighed. BD is calculated as the dry weight ( $\mathrm{g}$ ) divided by the wet sample volume $\left(\mathrm{cm}^{3}\right) . \mathrm{TC}_{\mathrm{org}}$ were determined by drying the subsamples at $60^{\circ} \mathrm{C}$. The dried subsamples then finely ground and weighed. $1 \mathrm{~N} \mathrm{HCl}$ treatment was applied to the subsamples to remove carbonates prior to $\mathrm{TC}_{\text {org }}$ determination by high temperature of oxidation in a Euro EA3000 elemental analyzer.

\subsubsection{Data handling}

Depending on the aims, pollen data of each core were groups according to the characteristic of ecosystem and the function of the taxa (e.g. mangrove, peatland, staple cultivation) or the plant categories (e.g. trees, shrubs, herbs, fern). For the interpretation of pollen data, the pollen records are divided into palynological zones following the agglomeration using constrained cluster analysis (CONISS; Grimm, 1987).

To assess the relationship between vegetation and $\mathrm{C}$ accumulation rate, a Principal Component Analysis (PCA) analysis was performed on both data. PCA analysis was also carried out to inspect the trend in vegetation change to assess the ecosystem resilience. Prior to each ordination, aquare root data transformation was applied to minimize the effect of over-represented taxa in the record. Such over-representation might occur due to the difference in pollen productivity and dispersal rate among taxa. For instance, the insect-pollinated plants, Callophyllum and Shorea (Lemmens and Bunyapraphatsara, 2003; Masuda et al., 2013) must have produced fewer amounts and 
have had a more limited dispersal of pollen than anemophilous taxa like MoraceaeUrticaceae (Haselhorst et al., 2013).

\subsection{Outline and content of the chapters}

The objectives of this research were developed into three separate manuscripts with a purpose to be published in peer-review international scientific journals. The published and submitted manuscripts are presented in the following chapters:

\section{Chapter 2 - Environmental dynamics and carbon accumulation rate of a tropical} peatland in Central Sumatra, Indonesia

Within this chapter, the understanding on the environmental and $\mathrm{C}$ accumulation dynamics of Sungai Buluh peatland is provided. The controlling factors of the peatland and its $\mathrm{C}$ sequestration dynamics, both natural and anthropogenic, are identified. The capacity of Sungai Buluh in storing peat $\mathrm{C}$ is compared with other tropical peatlands. This chapter also assesses the future fate of Sungai Buluh peatland as global $\mathrm{C}$ sink in regards to SLR.

Chapter 3 - Resilience of a peatland in Central Sumatra, Indonesia to anthropogenic disturbance: improving conservation and restoration designs using palaeoecology

The understanding on the resilience of Sungai Buluh peatland to anthropogenic disturbance is provided within this chapter. The recovery process and time of Sungai Buluh from past human disturbance are also discussed herein. This chapter also suggests some considerations to improve the efficiency and effectiveness of peatland conservation, management and restoration strategies. 
Chapter 4 - Climate and land use change governed environmental dynamics and carbon accumulation in the mangrove-fringed Segara Anakan lagoon, Java, Indonesia in the Anthropocene and beyond

This chapter provides the understanding on the environmental and $\mathrm{C}$ accumulation dynamics of Segara Anakan lagoon. The controlling factors, both natural and anthropogenic, of the lagoon and its $\mathrm{C}$ sequestration dynamics are identified. The capacity of Segara Anakan in storing C is compared with other mangrove dominated estuarine ecosystems on a global scale. This chapter also assesses the future fate of Segara Anakan lagoon as $\mathrm{C}$ sequester in regards to the climate and human influence.

\section{Chapter 5 - Synthesize}

This chapter synthesizes and discusses the main outcomes of this research. The outlooks for the future works and research are also proposed.

\section{References}

Adame, M.F., Hermoso, V., Perhans, K., Lovelock, C.E., Herrera-Silveira, J.A., 2015. Selecting cost-effective areas for restoration of ecosystem services. Conservation Biology 29(2), 493-502. doi:10.1111/cobi.12391

ADB (Asian Development Bank), 2006. Indonesia: Segara Anakan Conservation and Development Project. Complesion Report.

Agus, F., Wahyunto, Tala'ohu, S.H., Watung, R.L., 2004. Environmental consequences of landuse change in Indonesia. In: Conserving Soil and Water for Society: Sharing Solutions. $13^{\text {th }}$ International Soil Conservation Organisation Conference in Brisbane, July 2004

Aldrian, E., Susanto, R.D., 2003. Identification of three dominant rainfall regions within Indonesia and their relationship to sea surface temperature. International Journal of Climatology 23, 1435-1452. doi:10.1002/joc.950

Alongi, D.M., Murdiyarso, D., Fourqurean, J.W., Kauffman, J.B., Hutahaean, A., Crooks, S., Lovelock, C.E., Howard, J., Herr, D., Fortes, M., Pidgeon, E., Wagey, T., 2016. Indonesia's blue carbon: a globally significant and vulnerable sink for seagrass and mangrove carbon. Wetlands Ecology and Management 24(1), 3-13. doi:10.1007/s11273-015-9446-y

Appleby, P.G., Oldfield, F., 1978. The calculation of lead-210 dates assuming a constant rate of supply of unsupported ${ }^{210} \mathrm{~Pb}$ to the sediment. Catena 5 (1), $1-8$. 
Appleby, P.G., Oldfieldz, F., 1983. The assessment of ${ }^{210} \mathrm{~Pb}$ data from sites with varying sediment accumulation rates. Hydrobiologia 103, 29-35. doi:10.1007/BF00028424

Appleby, P.G., 2008. Three decades of dating recent sediments by fallout radionuclides: a review. The Holocene 18(1), 83-93.

Ardli, E.R., Wolff, M., 2009. Land use and land cover change affecting habitat distribution in the Segara Anakan lagoon, Java, Indonesia. Regional Environmental Change (2009) 9:235-243. doi:10.1007/s10113-008-0072-6.

Asean US CRMP, 1992. The integrated management plan of Segara Anakan, Cilacap, Central Java, Indonesia. ICLARM Technical Report.

Statistik Pekerjaan Umum, 2013. Buku Informasi Statistik Pekerjaan Umum. Pusat Pengolahan Data (Pusdata) Kementrian Pekerjaan Umum Republik Indonesia. Jakarta. Indonesia.

Bhagwat, S.A., Dudley, N. \& Harrop, S.R. (2011) Religious following in biodiversity hotspots: challenges and opportunities for conservation and development. Conservation Letters, 4, 234-240. doi: 10.1111/j.1755-263X.2011.00169.x

Biagioni, S., Krashevska, V., Achnopha, Y., Saad, A., Sabiham, S., Behling, H., 2015. $8000 y e a r s$ of vegetation dynamics and environmental changes of a unique inland peat ecosystem of the Jambi Province in Central Sumatra, Indonesia. Palaeogeography, Palaeoclimatology, Palaeoecology 440, 813-829. http://dx.doi.org/10.1016/j.palaeo.2015.09.048

Birks, H.J.B., 2012. Ecological palaeoecology and conservation biology : controversies, challenges, and compromises. International Journal of Biodiversity Science, Ecosystem Services \& Management 8, 292-304. http://dx.doi.org/10.1080/21513732.2012.701667.

Blaauw, M., Christen, J.A., 2011. Flexible paleoclimate age-depth models using an autoregressive gamma process. Bayesian Analysis 6, 457-474

Boavida, M., 1999. Wetlands: Most relevant structural and functional aspects. Limnetica 17, 57-63.

Boomgaard, P., 1992. Forest management and exploitation in Colonial Java, 1677-1897. Forest and Conservation History 36, 4-14. https://doi.org/10.2307/3983978.

BPS (Badan Pusat Statistic) Cilacap, 2017. Kecamatan Kampung Laut Dalam Angka. https://cilacapkab.bps.go.id/publication/

Brooks, J., Shaw, G., 1978. Sporopollenin: A review of its chemistry, palaeochemistry and geochemistry. Grana 17(2), 91-97.

Charman, D.J., Beilman, D.W., Blaauw, M., Booth, R.K., Brewer, S., Chambers, F.M., Christen, J.A., Gallego-Sala, A., Harrison, S.P., Hughes, P.D.M., Jackson, S.T., Korhola, A., Mauquoy, D., Mitchell, F.J.G., Prentice, I.C., Van Der Linden, M., De Vleeschouwer, F., Yu, Z.C., Alm, J., Bauer, I.E., Corish, Y.M.C., Garneau, M., Hohl, V., Huang, Y., Karofeld, E., Le Roux, G., Loisel, J., Moschen, R., Nichols, J.E., Nieminen, T.M., MacDonald, G.M., Phadtare, N.R., Rausch, N., Sillasoo, U., Swindles, G.T., Tuittila, E.S., Ukonmaanaho, L., Väliranta, M., Van Bellen, S., Van Geel, B., Vitt, D.H., Zhao, Y., 2013. Climate-related changes in peatland carbon accumulation during the last millennium. Biogeosciences 10, 929-944. 
doi:10.5194/bg-10-929-2013

Christen, J.A., Pérez, S., 2009. A new robust statistical model for radiocarbon data. Radiocarbon 51(3), 1047-1059.

Christen, J.A., 1994. Summarizing a set of radiocarbon determinations: a robust approach. Applied Statistics-Journal of the Royal Statistical Society Series C 43(3), 489-503.

Christie, P., 2004. Marine protected areas as biological success and social failures in Southeast Asia. American Fisheries Society Symposium 42, 155-164.

Cole, L.E.S., Bhagwat, S.A., Willis, K.J., 2015. Long-term disturbance dynamics and resilience of tropical peat swamp forests. Journal of Ecology 103, 16-30. doi:10.1111/1365-2745.12329

Committee on Characterization of Wetlands, 1995. Wetlands: Characteristics and Boundaries. National Research Council. National Academy Press, Washington DC, USA.

Cowardin, L.M., Carter, V., Golet, F.C., LaRoe, E.T., 1979. Classification of Wetlands and Deepwater Habitats of the United States. US Department of Interior, Fish and Wildlife Service. Washington, DC, USA.

Cribb, R., Ford, M., 2009. Indonesia beyond the Water's Edge: Managing an Archipelagic State. Institute of Southeast Asian Studies Publishing, Pasir Panjang, Singapore.

Crooks, S., Herr, D., Tamelander, J., Laffoley, D., Vandever, J., 2011. Restoration and management of coastal wetlands and near-shore marine ecosystems. Environment Department Paper. The World Bank, Washington DC, USA.

Croudace, I.W., Rindby, A., Rothwell, R.G., 2006. ITRAX: description and evaluation of a new multi-function X-ray core scanner. In: Rothwell, R.G. (Ed.), New Techniques in Sediment Core Analysis. Geological Society of London, London, pp. 51-63.

Davies, A.L., Bunting, M.J., 2010. Applications of palaeoecology in conservation. The Open Ecology Journal 3, 54-67. doi:10.2174/1874213001003020054

Davies, A.L., 2007. Upland agriculture and environmental risk: a new model of upland land-use based on high spatial-resolution palynological data from West Affric, NW Scotland. Journal of Archaeological Science 34, 2053-2063. doi:10.1016/j.jas.2007.02.003

Dharmawan, B., Böcher, M., Krott, M., 2016. The failure of the mangrove conservation plan in Indonesia: Weak research and an ignorance of grassroots politics. Ocean and Coastal Management $250-259$. https://doi.org/10.1016/j.ocecoaman.2016.06.019

Dommain, R., Couwenberg, J., Joosten, H., 2011. Development and carbon sequestration of tropical peat domes in south-east Asia: Links to post-glacial sealevel changes and Holocene climate variability. Quaternary Science Reviews 30, 999-1010. doi:10.1016/j.quascirev.2011.01.018 
Donato, D.C., Kauffman, J.B., Murdiyarso, D., Kurnianto, S., Stidham, M., Kanninen, M., 2011. Mangroves among the most carbon-rich forests in the tropics. Nature Geoscience 4, 293-297. doi:10.1038/ngeo1123

Eong, O.J., 1993. Mangroves - A carbon source and sink. Chemosphere 27(6), 10971107.

Faegri, K., Iversen, J., 1989. In: Textbook of Pollen Analysis, revised by Faegri, K., Kaland, P.E., Krzywinski, K. John Wiley, New York.

Finlayson, C.M., Davidson, N.C., Spiers, A.G., Stevenson, N.J., 1999. Global wetland inventory - current status and future priorities. Marine and Freshwater Research 50, 717-727. https://doi.org/10.1071/MF99098

Friess, D.A., Thompson, B.S., Brown, B., Amir, A.A., Cameron, C., Koldewey, H.J., Sasmito, S.D., Sidik, F., 2016. Policy challenges and approaches for the conservation of mangrove forest in Southeast Asia. Conservation Biology 30(5), 933-949. doi:10.1111/cobi.12784

Friess, D.A., 2016. Ecosystem services and disservices of mangrove forests: insights from historical colonial observations. Forests 7(9), 186. doi:10.3390/f7090183.

Giblett, R., 1996. A cultural history of wetlands. Wetlands 18(1), 160-161.

Godwin, H., 1934. Pollen Analysis: An Outline of the Problems and Potentialities of the Method. Part II. General Applications of Pollen Analysis. The New Phytologist 33(5), 325-358

Graham, L.L.B., Turjaman, M., Page, S.E., 2013. Shorea balangeran and Dyera polyphylla (syn. Dyera lowii) as tropical peat swamp forest restoration transplant species: effects of mycorrhizae and level of disturbance. Wetlands Ecology and Management 21, 307-321. doi:10.1007/s11273-013-9302-x

Grimm, E.C., 1987. CONISS: A FORTRAN 77 program for stratigraphically constrained cluster analysis by the method of incremental sum of squares. Computers \& Geosciences 13, 13-35.

Gunawan, H., Kobayashi, S., Mizuno, K., Kono, Y., 2012. Peat swamp forest types and their regeneration in Giam Siak Kecil-Bukit Batu Biosphere Reserve, Riau, East Sumatra, Indonesia. Mires and Peat 10(5), 1-17.

Haselhorst,D.S., Moreno, J.E., Punyasena, S.W., 2013. Variability within the 10-Year Pollen Rain of a Seasonal Neotropical Forest and Its Implications for Paleoenvironmental and Phenological Research. PLoS One 8(1), e53485. doi:10.1371/journal.pone.0053485

Higuera, P.E., Brubaker, L.B., Anderson, P.M., Hu, F.S., Brown, T.A., 2009. Vegetation mediated the impacts of postglacial climatic change on fire regimes in the south-central Brooks Range, Alaska. Ecological Monographs 79, 201-219. doi:10.1890/07-2019.1

Hinrichs, S., Nordhaus, I., Geist, S.J., 2009. Status, diversity and distribution patterns of mangrove vegetation in the Segara Anakan lagoon, Java, Indonesia. Regional Environmental Change 9, 275-289. doi:10.1007/s10113-008-0074-4 
Holmes, G., 2013. Exploring the relationship between local support and the success of protected areas. Conservation and Society 11(1), 72-82. doi: 10.4103/09724923.110940

Holtermann, P., Burchard, H., Jennerjahn, T., 2009. Hydrodynamics of the Segara Anakan lagoon. Regional Environmental Change 9, 245-258. doi:10.1007/s10113-008-0075-3

Hutomo, M, Moosa, M.K., 2005. Indonesian marine and coastal biodiversity: present status. Indian Journal of Marine Sciences 34(1), 88-97.

Jackson, S.T., Hobbs, R.J., 2009. Ecological restoration in the light of ecological history. Science 325, 567-569. doi: 10.1126/science.1172977.

Jauhiainen, J., Hooijer, A., Page, S.E., 2012. Carbon dioxide emissions from an Acacia plantation on peatland in Sumatra, Indonesia. Biogeosciences 9, 617-630. doi:10.5194/bg-9-617-2012

Jones, S.E., Pearce, K.G., 2015. A pollen morphology study from the Kelabit Highlands of Sarawak, Malaysian Borneo. Palynology 39, 150-204. doi:10.1080/01916122.2014.940472

Jowsey, P.C., 1966. An improved peat sampler. New Phytologist 65, 245-248. doi:10.1111/j.1469-8137.1966.tb06356.x

Keller, J.K., 2011. Wetlands and the global carbon cycle: what might the simulated past tell us about the future? New Phytologist 192, 787-792. doi:10.1111/j.14698137.2011.03954.x

Kylander, M.E., Lind, E.M., Wastegård, S., Löwemark, L., 2011. Recommendations for using XRF core scanning as a tool in tephrochronology. The Holocene 22(3), 371375. doi:10.1177/0959683611423688.

Le Quéré, C., Raupach, M.R., Canadell, J.G., Marland, G. et al. Trends in the sources and sinks of carbon dioxide. Nature Geoscience 2, 831-836. doi:10.1038/ngeo689

Lemmens, R.H.M.J., Bunyapraphatsara, N. 2003. Plant Resources of South-East Asia 12(3) Medicinal and Poisonous Plants. Prosea Foundation, Bogor, Indonesia.

Li, Z., Saito, Y., Mao, L., Tamura, T., Li, Z., Song, B., Zhang, Y., Lu, A., Sieng, S., Li, J., 2012. Mid-Holocene mangrove succession and its response to sea-level change in the upper Mekong River delta, Cambodia. Quaternary Research 78, 386-399. doi:10.1016/j.yqres.2012.07.001.

Lubis, A.A., 2006. Constant rate of supply (CRS) model for determining the sediment accumulation rates in the coastal area using ${ }^{210} \mathrm{~Pb}$. Journal of Coastal Development 10(1), 9-18.

Lukas, M., 2017. Widening the scope: linking coastal sedimentation with watershed dynamics in Java, Indonesia. Regional Environmental Change 17, 901-914. doi:10.1007/s10113-016-1058-4

Lyver, P.O., Wilmshurst, J.M., Wood, J.R., Jones, C.J., Fromont, M., Bellingham, P.J., Stone, C., Sheehan, M., Moller, H., 2015. Looking Back for the Future: Local Knowledge and Palaeoecology Inform Biocultural Restoration of Coastal 
Ecosystems in New Zealand. Human Ecology 43, 681-695. doi:10.1007/s10745015-9784-7

Máñez, K.S., 2010. Java's forgotten pearls: the history and disappearance of pearl fishing in the Segara Anakan lagoon, South Java, Indonesia. Journal of Historical Geography 36, 367-376. doi:10.1016/j.jhg.2010.03.004.

Mao , L., Batten, D.J., Fujiki, T., Li, Z., Dai, L., Wenig, C., 2012. Key to mangrove pollen and spores of southern China: an aid to palynological interpretation of Quaternary deposits in the South China Sea. Review of Palaeobotany and Palynology 176-177, 41-67. doi:10.1016/j.revpalbo.2012.03.004.

Margono, B.A., Turubanova, S., Zhuravleva, I., Potapov, P., Tyukavina, A., Baccini, A., Goetz, S., Hansen, M.C., 2012. Mapping and monitoring deforestation and forest degradation in Sumatra (Indonesia) using Landsat time series data sets from 1990 to 2010. Environmental Research Letters 7(3), 034010. http://dx.doi.org/10.1088/1748-9326/7/3/034010

Margono, B.A., Bwangoy, J.B., Potapov, P.V., Hansen, M.C., 2014a. Mapping wetlands in Indonesia using Landsat and PALSAR data-sets and derived topographical indices. Geo-spatial Information Science 17(1), 60-71. doi:10.1080/10095020.2014.898560

Margono, B.A., Potapov, P., Turubanova, S., Stolle, F., Hansen, M.C., 2014b. Primary forest cover loss in Indonesia over 2000-2012. Nature Climate Change 4, 730-735. doi:10.1038/nclimate2277

Maron, M., Rhodes, J.R., Gibbons, P., 2012. Calculating the benefit of conservation actions. Conservation Letters 6(5), 359-367. doi: 10.1111/conl.12007

Masuda, S., Tani, N., Ueno, S., Lee, S.L, Muhammad, N., Kondo, T., Numata, S., Tsumura, Y., 2013. Non-Density Dependent Pollen Dispersal of Shorea maxwelliana (Dipterocarpaceae) Revealed by a Bayesian Mating Model Based on Paternity Analysis in Two Synchronized Flowering Seasons. PLoS ONE 8(12), e82039. doi:10.1371/journal.pone.0082039

Matthews, E., Fung, I., 1987. Methane emissions from natural wetlands: global distribution area and environmental characteristic of sources. Global Biochemical Cycles 1, 61-86.

McCarroll, J., Chambers, F.M, Webb, J.C., Thom, T. 2017. Application of palaeoecology for peatland conservation at Mossdale Moor, UK. Quaternary International 432, 39-47. http://dx.doi.org/10.1016/j.quaint.2014.12.068

Mcleod, E., Hinkel, J., Vafeidis, A.T., Nicholls, R.J., Harvey, N., Salm, R., 2010. Sealevel rise vulnerability in the countries of the Coral Triangle. Sustainable Science 5(2): 207-222. doi:10.1007/s11625-010-0105-1

Measey, M., 2010. Indonesia: A vulnerable country in the face of climate change. Global Majority E-Journal 1(1), 31-45.

Melati, D.N., Jaya, I.N.S., Pérez-Cruzado, C., Zuhdi, M., Fehrmann, L., Magdon, P., Kleinn, C., 2015. Spatio-temporal analysis on land transformation in a forested tropical landscape in Jambi Province, Sumatra. In conference presentation of European Geosciences Union General Assembly 17 April 2015. Vienna, Austria. 
Miettinen, J., Hooijer, A., Tollenaar, D., Page, S.E., Malins, C., Vernimmen, R., Shi, C., Liew, S.C., 2012. Extent of industrial plantations on Southeast Asian peatlands in 2010 with analysis of historical expansion and future projections. Global Change Biology and Bioenergy 4, 908-18.

Mitra, S., Wassmann, R., Vlek, P.L.G., 2003. Global inventory of wetlands and their role in the carbon cycle. ZEF-Discussion Papers on Development Policy 64. Center for Development Research, Bonn, Germany.

Mitsch, W.J., Gosselink, J.G., 2000. The value of wetlands: importance of scale and landscape setting. Ecological Economics 35, 25-33.

Murdiyarso, D., Purbopuspito, J., Kauffman, J.B., Warren, M.W., Sasmito, S.D., Donato, D.C., Manuri, S., Krisnawati, H., Taberima, S., Kurnianto, S., 2015. The potential of Indonesian mangrove forests for global climate change mitigation. Nature Climate Change 5, 1089-1092. doi:10.1038/nclimate2734

Nerem, R.S., Chambers, D.P., Choe, C., Mitchum, G.T., 2010. Estimating mean sea level change from the TOPEX and Jason Altimeter Missions. Marine Geodesy 33, 435-446. http://dx.doi.org/10.1080/01490419.2010.491031

Nicholls, R.J., Cazenave, A., 2010. Sea-level rise and its impact on coastal zones. Science 328, 1517-1520. doi: 10.1126/science.1185782.

Nicholls, R.J., Toll, R.S., Impacts and responses to sea-level rise: a global analysis of the SRES scenarios over the twenty-first century. Philosophical Transaction of the Royal Society A 364, 1073-1095. doi:10.1098/rsta.2006.1754

Nicholls, R.J., 2004. Coastal flooding and wetland loss in the $21^{\text {st }}$ century: changes under the SRES climate and socio-economic scenarios. Global Environmental Change 14, 69-86. doi: 10.1016/j.gloenvcha.2003.10.007

Niedermeyer, E.M., Sessions, A.L., Feakins, S.J., Mohtadi, M., 2014. Hydroclimate of the western Indo-Pacific Warm Pool during the past 24,000 years. Proceedings of the National Academy of Sciences 111, 9402-9406. doi:10.1073/pnas.1323585111

Niering, W., 1985. Wetlands. Knopf, New York, USA.

Nijman, V., 2003.Distribution, habitat use and conservation of the endemic Chestnutbellied Hill-partridge (Arborophila javanica) in fragmented forest of Java, Indonesia. Emu 103, 133-140.

Noegrahati, S., Narsito, 2007. Integrated water monitoring to support the management of healthy Segara Anakan estuary. Jurnal Manusia dan Lingkungan 14(1), 35-45.

Nogué, S., Nascimento, L., Froyd, C.A., Wilmshurst, J.M., de Boer, E.J., Coffey, E.E., Whittaker, R.J., Fernández-Palacios, J., Willis, K.J., 2017. Island biodiversity conservation needs palaeoecology. Nature Ecology and Evolution 1, 0181. doi:10.1038/s41559-017-0181

Nurjanah, S., Octavia, D., Kusumadewi, F., 2013. Identifikasi lokasi penanaman kembali ramin (Gonystilus bancanus Kurz) di hutan rawa gambut Sumatra dan Kalimantan. Pusat Penelitian dan Pengembangan Konservasi dan Rehabilitasi with International Tropical Timber Organization (ITTO)-CITES Phase 2 Project, Bogor, Indonesia. 
Olson, J., Berry, L., 2004. Land degradation in Java, Indonesia: its extent and impact. Global Mechanism. The World Bank, Washington DC, USA.

Ono, J., Yong, J.W.H., Takayama, K., Bin Saleh, M., Wee, A.K., Asakawa, T., Yllano, O.B., Salmo III, S.G., Suleiman, M., Tung, N.X., Soe, K.K., Meenakshisundaram, S.H., Watano, Y., Webb, E.L., Kajita, T., 2016. Bruguiera hainesii, a critically endangered mangrove species, is a hybrid between $B$. cylindrica and $B$. gymnorhiza (Rhizophoraceae). Conservation Genetics 17, 1137. doi:10.1007/s10592-016-0849-y

Osaki, M., Nursyamsi, D., Noor, M., Wahyunto, Segah, H., 2016. Peatland in Indonesia. In: Osaki M., Tsuji, N. (Eds.) Tropical Peatland Ecosystems. Springer, Tokyo, Japan.

Page, S.E., Baird, A.J., 2016. Peatlands and global change: Response and Resilience. Annual Reviews of Environment and Resource 41, 35-57. doi: 10.1146/annurevenviron-110615-085520

Page, S.E., Siegert, F., Rieley, J.O., Boehm, H.V., Jaya, A., Limin, S., 2002. The amount of carbon released from peat and forest fires in Indonesia during 1997. Nature 420, 61-65. doi:10.1038/nature01131

Page, S., Wust, R., Weiss, D., Rieley, J.O., Shotyk, W., Limin, S.H., 2004. A record of Late Pleistocene and Holocene carbon accumulation and climate change from an equatorial peat bog (Kalimantan, Indonesia): implication of past, present and future carbon dynamics. Journal of Quaternary Science 19, 625-635. doi:10.1002/jqs. 884

Page, S.E., Rieley, J.O., Banks, C.J., 2011. Global and regional importance of the tropical peatland carbon pool. Global Change Biology 17, 798-818. doi:10.1111/j.1365-2486.2010.02279.x

Philander, S.G.H., 1983. El Niño southern oscillation phenomena. Nature 302, 295-301. doi:10.1038/302295a0

Philander, S.G.H., 1990. El Niño, La Niña and the southern oscillation, $1^{\text {st }}$ edition. Academic Press, London, United Kingdom.

Poliodoro, B.A., Carpenter, K.E., Collins, L., Duke, N.C., Ellison, A.M., Ellison, J.C., Farnsworth, E.J., Fernando, E.S., Kathiresan, K., Koedam, N.E., Livingstone, S.R., Miyagi, T., Moore, G.E., Nam, V.N., Ong, J.E., Primavera, J.H., Salmo, S.G., Sanciangco, J.C., Sukardjo, S., Wang, Y., Yong, J.W., 2010. The loss of species: mangrove extinction risk and geographic areas of global concern. PlosOne 5(4): e10095. https://doi.org/10.1371/journal.pone.0010095

Posa, M.R.C., Wijedasa, L.S., Corlett, R.T., 2011. Biodiversity and Conservation of Tropical Peat Swamp Forests. BioScience 61, 49-57. doi:10.1525/bio.2011.61.1.10

Prentice, C., 1988. Records of vegetation in time and space: the principles of pollen analysis. In: Huntley B., Webb T. (Eds.) Vegetation history. Handbook of Vegetation Science Vol 7. Springer, Dordrecht, The Netherland. doi: 10.1007/97894-009-3081-0_2 
Qian, J., Robertson, A.W., Moron, V., 2010. Interactions among ENSO, the Monsoon, and Diurnal Cycle in Rainfall Variability over Java, Indonesia. Journal of the Atmospheric Sciences 67, 3509-3524. doi:10.1175/2010JAS3348.1

R Core Team, 2014. R: A language and environment for statistical computing. $\mathrm{R}$ Foundation for Statistical Computing, Vienna, Austria. http://www.R-project.org/.

Rahmstorf, S., 2010. A new view of sea level rise. Nature Reports Climate Change 4, 44-45. doi:10.1038/climate.2010.29

Ramsar Convention, 1982. The Convention on Wetlands. http://www.ramsar.org/

Ramsey, C.B., 2009. Bayesian analysis for radiocarbon dates. Radiocarbon 51(1), 337360.

Reitz, E.J., Shackley, M., 2012. Environmental Archaeology. In: Orser, C.E., Schiffer, M.B. (Eds.) Manuals in Archaeological Method, Theory and Technique. Springer, New York, USA.

Rey Benayas, J.M., Bullock, J.M. \& Newton, A.C. (2008) Creating woodland islets to reconcile ecological restoration, conservation, and agricultural land use. Frontiers in Ecology and the Environment, 6(6), 329-336, doi:10.1890/070057

Rhodes, A.N., 1998. A method for the preparation and quantification of microscopic charcoal from terrestrial and lacustrine sediment cores. The Holocene 8, 113-117. doi:10.1191/095968398671104653

Saji, N.H., Goswami, B.N., Vinayachandran, P.N., Yamagata, T., 1999. A dipole mode in the tropical Indian Ocean. Nature 401, 360-3. doi:10.1038/43854

Seppä, H. 2009. Palaeoecology. eLS. doi:10.1002/9780470015902.a0003232

Siburian, R., Haba, J., 2016. Konservasi mangrove dan kesejahteraan masyarakat. Yayasan Pustaka Obor Indonesia, Jakarta, Indonesia.

Siikamäaki, J., Sanchirico, J.N., Jardine, S.L., 2012. Global economic potential for reducing carbon dioxide emissions from mangrove loss. Proceedings of the National Academy of Sciences of the United States of America 109, 14369-14374. doi:10.1073/pnas.1200519109

Smiet, A.C., 1990. Forest ecology on Java: conversion and usage in a historical perspective. . Journal of Tropical Forest Science 2(4), 286 - 302.\#

Sukarjo, S., 2014. Fisheries associated with mangrove ecosystem in Indonesia: A view from mangrove ecologist. Biotropica 23, 13-39.

Soerianegara, I., Lemmens, R.H.M.J., 1994. Plant Resources of South-East Asia No. 5(1). Timber trees: Major commercial timbers. Prosea Foundation, Bogor, Indonesia.

Stevenson, J., Haberle, S., 2005. Macro Charcoal Analysis : A modified technique used by the Department of Archaeology and Natural History. Australian National University, Canberra.

Sukardi, Y., 2010. Permasalahan Kawasan Segara Anakan. Perencanaan Pembangunan, $2-10$.

Syaukat, Y., 2011. The impact of climate change on food production and security and 
its adaptation programs in Indonesia. Journal of International Society for Southeast Asian Agricultural Sciences 17(1), 40-51.

Tata, H.L., van Noordwidjk, M., Jasnari, Widayati, A., 2016. Domestication of Dyera polyphylla (Miq.) Steenis in peatland agroforestry systems in Jambi, Indonesia. Agroforest System 90, 617-630. doi:10.1007/s10457-015-9837-3

Tjoa-Bonatz, M.L., Neidel, J.D., Widiatmoko, A., 2009. Early Architectural Images from Muara Jambi on Sumatra, Indonesia. Asian Perspectives 48, 32-55. doi:10.1353/asi.0.0009

van Dijk, A.I.J.M., Bruijnzeel, L.A., Purwanto, E., 2004. Soil conservation in upland Java, Indonesia: past failures, recent findings and future prospects. In: Conserving Soil and Water for Society: Sharing Solutions. $13^{\text {th }}$ International Soil Conservation Organisation Conference in Brisbane, July 2004

van Eijk, P., Leenman, P., Wibisono, I.T.C., Giesen, W., 2009. Regeneration and restoration of degraded peat swamp forest in Berbak National Park, Jambi, Sumatra, Indonesia. Malayan Nature Journal 61(3), 223 - 241.

Villa, F., Bagstad, K.J., Voigt, B., Johnson, G.W., Athanasiadis, I.N., Balbi, S., 2014. The misconception of ecosystem disservices: How a catchy term may yield the wrong message for science and society. Ecosystem Services 10, 52-53. doi: 10.1016/j.ecoser.2014.09.003

Warner, B.G., Rubec, C.D.A., 1997. The Canadian Wetland Classification System. Wetland Research Center. University of Waterloo, Ontario, Canada.

Webb, E.L., Friess, D.A., Krauss, K.W., Cahoon, D.R., Guntenspergen, G.R., Phelps, J., 2003. A global standard for monitoring coastal wetland vulnerability to accelerated sea-level rise. Nature Climate Change 3, 458-465. doi:10.1038/nclimate1756

White, A.T., Martosubroto, P., Sadorra, M.S.M., 1989. The coastal environmental profile of Segara Anakan-Cilacap, South Java, Indonesia. ICLARM technical reports on coastal area management series no. 25, International Centre for Living Aquatic Resources Management, Manila.

Whitlock C., Larsen C., 2002. Charcoal as a Fire Proxy. In: Smol J.P., Birks H.J.B., Last W.M., Bradley R.S., Alverson K. (Eds.) Tracking Environmental Change Using Lake Sediments. Developments in Paleoenvironmental Research Vol 3. Springer, Dordrecht, The Netherland. doi:10.1007/0-306-47668-1_5

Whittle, A., Gallego-Salla, A., 2016. Vulnerability of the peatland carbon sink to sealevel rise. Scientific Reports 6, 2875. doi: 10.1038/srep28758

Willis, K.J., Birks, H.J.B., 2006. What is natural? The need for a long-term perspective in biodiversity conservation. Science 314(5803), 1261-1265. doi:10.1126/science. 1122667

Witrianto, 2014. Potensi sejarah dan purbakala DAS Batanghari. Analisis Sejarah 5, 6879.

Wong, M.H., 2004. Wetlands ecosystems in Asia: Function and management. Elsevier, Oxford, United Kingdom. 
Wright, H. E., Jr. 1967. A square-rod piston sampler for lake sediments. Journal of Sedimentary and Petrology 37(3): 975-976.

Wüst, R.A.J., Bustin, R.M., Lavkulich, L.M., 2003. New classification systems for tropical organic-rich deposits based on studies of the Tasek Bera Basin, Malaysia. Catena 53, 133-163. doi:10.1016/S0341-8162(03)00022-5

Yu, Z., Beilman, D.W., Frolking, S., MacDonald, G.M., Roulet, N.T., Camill, P., Charman, D.J., 2011. Peatlands and Their Role in the Global Carbon Cycle. EOS 92, 97-108. doi:10.1029/2011EO120001

Zedler, J.B., Kercher, S., 2005. Wetland resources: Status, trends, ecosystem services and restorability. Annual Review of Environment and Resources 30, 39-74. doi: 10.1146/annurev.energy.30.050504.144248

Zikra, M., Suntoyo, Lukijanto, 2015. Climate change impacts on Indonesian coastal areas. Procedia Earth and Planetary Science 14, 57-63. Doi:10.1016/j.proeps.2015.07.085 


\section{Chapter 2}

\section{Environmental dynamics and carbon accumulation rate of a tropical peatland in Central Sumatra, Indonesia}

Kartika Anggi Hapsari ${ }^{1 *}$, Siria Biagioni ${ }^{1}$, Tim C. Jennerjahn ${ }^{2}$, Peter Meyer Reimer ${ }^{3}$, Asmadi Saad ${ }^{4}$, Yudhi Achnopha ${ }^{4}$, Supiandi Sabiham ${ }^{5}$, Hermann Behling ${ }^{1}$

${ }^{1}$ Department of Palynology and Climate Dynamics - Albrecht-von-Haller Institute for Plant Sciences, Georg-August-University of Goettingen, Germany

2 Department of Biogeochemistry and Geology, Leibniz Center for Tropical Marine Ecology (ZMT), Bremen, Germany

${ }^{3}$ Department of Biological Science, Goshen College, Goshen, Indiana, USA

${ }^{4}$ Department of Soil Science, University of Jambi, Jambi, Indonesia

${ }^{5}$ Department of Soil Science and Land Resource, Bogor Agriculture University (IPB), Bogor, Indonesia

Quaternary Science Reviews (2017) 169: 173-187

doi:10.1016/j.quascirev.2017.05.026 


\section{$\underline{\text { Abstract }}$}

Tropical peatlands are important for the global carbon cycle as they store $18 \%$ of the total global peat carbon. As they are vulnerable to changes in temperature and precipitation, a rapidly changing environment endangers peatlands and their carbon storage potential. Understanding the mechanisms of peatland carbon accumulation from studying past developments may, therefore, help to assess the future role of tropical peatlands. Using a multi-proxy palaeoecological approach, a peat core taken from the Sungai Buluh peatland in Central Sumatra has been analyzed for its pollen and spore, macro charcoal and biogeochemical composition. The result suggests that peat and $\mathrm{C}$ accumulation rates were driven mainly by sea level change, river water level, climatic variability and anthropogenic activities. It is also suggested that peat $\mathrm{C}$ accumulation in Sungai Buluh is correlated to the abundance of Freycinetia, Myrtaceae, Calophyllum, Stemonuraceae, Ficus and Euphorbiaceae. Sungai Buluh has reasonable potential for being a future global tropical peat $\mathrm{C}$ sinks. However, considering the impact of rapid global climate change in addition to land-use change following rapid economic growth in Indonesia, such potential may be lost. Taking advantage of available palaeoecological records and advances made in Quaternary studies, some considerations for management practice such as identification of priority taxa and conservation sites are suggested.

Keywords: Holocene, palaeoecology, Southeastern Asia, vegetation dynamics, stable isotopes, peatland, C accumulation rate, ecological process, controlling factor, Sumatra 


\subsection{Introduction}

Peatlands play a major role in the global carbon cycle by storing around $600 \mathrm{Gt}$ carbon or one third of the total global carbon pool (Gorham, 1991; Yu et al., 2011). Around $18 \%$ of the global peat carbon pool is stored in tropical regions, with around $65 \%$ stored in SE Asia (Page et al., 2011; Dargie et al., 2017). In SE Asia the largest share of tropical peat carbon is stored in Indonesia, with an estimated 57.4 Gt making up $65 \%$ of the total peat carbon in the tropics (Page et al., 2011). The estimation, however, cannot be precisely made due to limited information about the peat basal ages and the rates of carbon accumulation (Page et al., 2004; Dommain et al., 2011). SE Asian peatlands are distributed mainly in the river deltas and coastal plains of the islands of Sumatra and Borneo (Dommain et al., 2011; Veloo et al., 2014). Due to land use conversion and drainage following the economic growth of Indonesia, the existence of these peatlands is endangered (Miettinen et al., 2012).

Peatlands are sensitive to changes in precipitation and temperature, and are therefore vulnerable to global climate change (Page et al., 2011). A decrease in precipitation and an increase in temperature can lower the water table in peatlands, which in turn can increase the decomposition rate of the accumulated organic material (OM; Couwenberg et al., 2010). An experimental study in a peatland in Manitoba, Canada suggests that a temperature increase of $4^{\circ} \mathrm{C}$ would cause a 40 to $80 \%$ loss of organic carbon due to water-table lowering (Ise et al., 2008). An approximate 30\% decrease in annual mean C accumulation following a three years-long $60 \%$ precipitation reduction is reported from a study in Switzerland (Bragazza et al, 2016).

Climate is, however, not the only factor controlling the rate of peat $\mathrm{C}$ accumulation (Charman et al., 2015; Dommain et al., 2015). For instance, an experimental study in 
Mer Bleue bog, Canada reported that the change in vegetation cover could lessen the $\mathrm{C}$ sink's capacity by altering the OM quality from slowly-decomposed Sphagnum to more decomposable vascular plants such as Chamaedaphne calyculata and Ledum groenlandicum (Juutinen et al., 2010). Yet, other factors besides climate such as watertable fluctuation and vegetation type are hardly discussed (Charman et al., 2015). Differently from northern peatlands where the relationship between climate, ecosystem dynamics and $\mathrm{C}$ accumulation is well studied, the information for tropical regions is sparse (Page et al., 1999; Yu et al., 2011). Consequently, the mechanisms driving peat C accumulation in tropical regions are still poorly understood, in particular in Indonesia with its extensive peatlands. Such knowledge is important for an improved understanding of past global carbon cycling as well as for an assessment of the future role of tropical peatlands in the rapidly changing environment (Page et al., 2004; Charman et al., 2013).

Supporting information such as palaeovegetational and palaeoenvironmental data which is required to identify the driving factors is also lacking (Birks, 2012; Dommain et al, 2015). For instance, a palaeoecological study in the Alaskan boreal forest found that fires occurred more frequently during wetter climatic conditions, contrary to the common assumption that fire is closely related to drought (Lynch et al., 2004). During the wetter conditions, the extensive grass growth increased fuel availability which than led to more frequent fire occurrence (Lynch et al., 2004).

In order to better understand the mechanisms of $\mathrm{C}$ accumulation in tropical peatlands, a multi-proxy palaeoecological study of a core from a peatland in the coastal area of Sumatra has been undertaken. These specific questions are addressed: 1 . What factors control $\mathrm{C}$ accumulation in this peatland? 2. Is there any relationship between the rate of 
$\mathrm{C}$ accumulation and the composition of particular taxa? 3. How does the long-term (apparent) rate of $\mathrm{C}$ accumulation (LORCA) compare in the global context?

\subsection{Study site}

The Sungai Buluh peatland is situated $19 \mathrm{~km}$ from the coastline with an elevation ranging from 9 to $25 \mathrm{~m}$ above sea level (asl). The restoration area of Sungai Buluh $(18,000 \mathrm{ha})$ is located in the Tanjung Jabung Regency, approximately $30 \mathrm{~km}$ north-east of the city of Jambi in Central Sumatra (Fig. 2.1a). The climate of the area is tropical humid, with yearly precipitation patterns mainly controlled by seasonal variation of the Asian-Australian monsoon and the Intertropical Convergence Zone (ITZC; Saji et al., 1999). Mean annual temperature is $26^{\circ} \mathrm{C}$ with little variation throughout the year. Average annual rainfall is $2400 \mathrm{~mm}$, with a slightly drier season corresponding to the onset of the southeast monsoon from June to September (Aldrian and Susanto, 2003; Karger et al., 2016). The inter-annual variability of rainfall is influenced by the $E l$ Niño-Southern Oscillation (ENSO; Aldrian and Susanto, 2003) and the Indian Ocean Dipole (IOD; Saji et al., 1999).

In general, the information on this protected peatland is sparse. The vegetation covering the restoration area is classified as secondary peat swamp forest (PSF; Melati et al., 2015). According to Tata et al., (2016) the original peat swamp forest cover was reduced by El Niño-related fires in 1997. Later in 2003, Shorea pauciflora and Dyera polyphylla were replanted in the Sungai Buluh area following instructions from the Department of Forestry of the Jambi Province (Nurjanah et al., 2013). The water table in this peatland fluctuated from 0.0 to $0.7 \mathrm{~m}$ (average $0.3 \mathrm{~m}$ ) below the peat surface (http://space.geocities.jp/hkdkalimantan/jambi1/jambilhome.html). The area around the site is converted into agricultural field and plantations (Fig. 2.1b) such as oil palm 
(Elaeis guineensis) and pulp wood (Acacia spp.). The ancient Muara Jambi temple complex is found around $28 \mathrm{~km}$ south of the study area, on the banks of the Batang Hari River (Fig. 2.1a). The complex covers about $12 \mathrm{~km}^{2}$ and it dates back to somewhere between the $9^{\text {th }}$ and $14^{\text {th }}$ centuries (Tjoa-Bonatz et al., 2009) and was supposedly the center of the Malayu Empire (Witrianto, 2014). This ancient kingdom in Sumatra is reported to have played a significant role in trading from the $10^{\text {th }}$ to the $13^{\text {th }}$ centuries as an overseas gateway for goods from the Sumatran hinterland, including forest and animal products (Witrianto, 2014). Such a significant role was lost after the conquest of the Majapahit Empire in the $14^{\text {th }}$ century (Locher-Scholten, 2003).
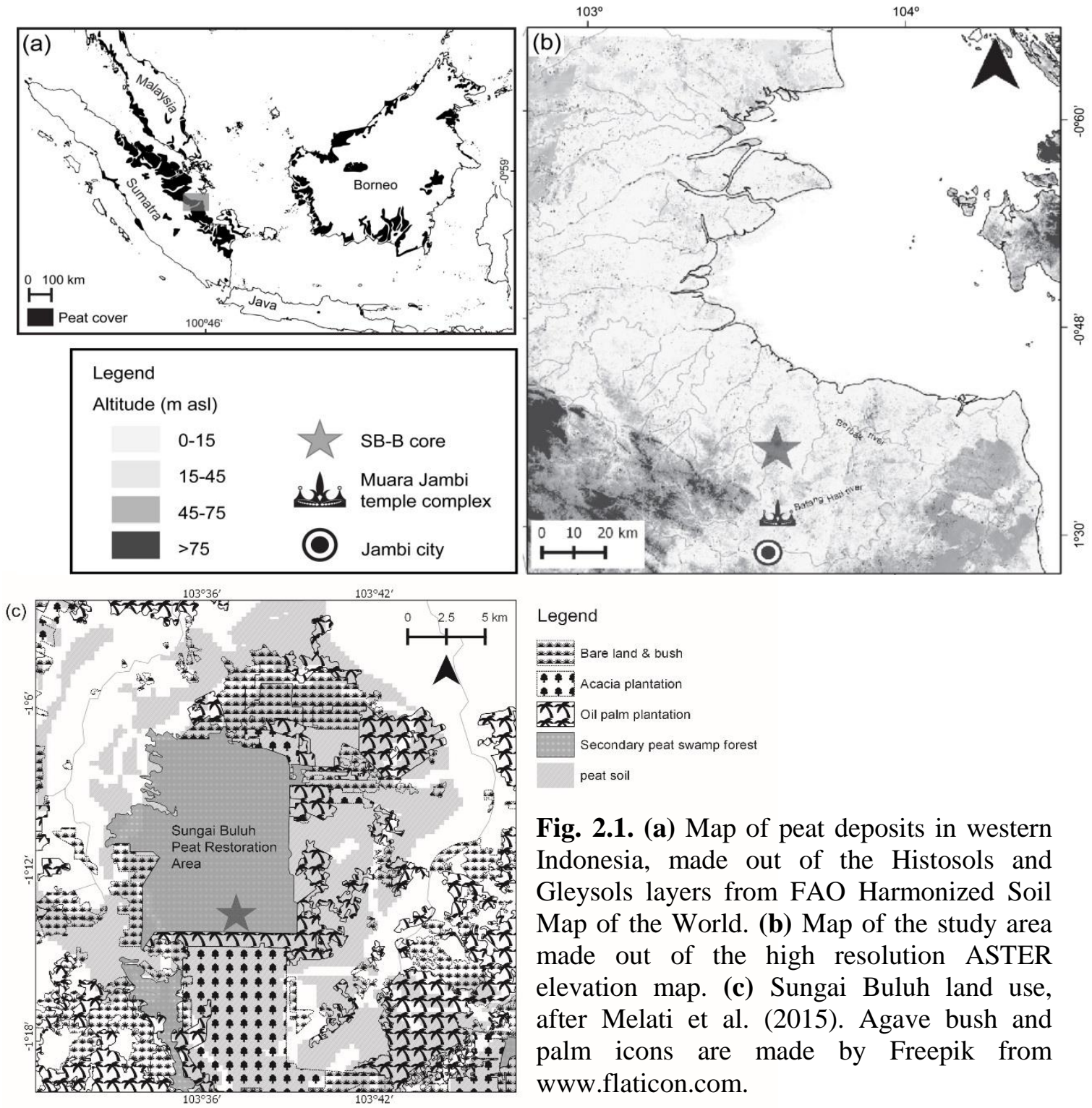
Legend
Ex: Bare land \& bush
: Acacia plantation
7. Oil palm plantation
Secondary peat swamp forest
peat soil

Fig. 2.1. (a) Map of peat deposits in western Indonesia, made out of the Histosols and Gleysols layers from FAO Harmonized Soil Map of the World. (b) Map of the study area made out of the high resolution ASTER elevation map. (c) Sungai Buluh land use, after Melati et al. (2015). Agave bush and palm icons are made by Freepik from www.flaticon.com. 


\subsection{Material and methods}

In 2013, a $350 \mathrm{~cm}$-long core (SB-B) was collected in the Sungai Buluh peat restoration area using a Russian Corer (Jowsey, 1966). The SB-B core (1¹4'10” S, 103³7’12” E; $18 \mathrm{~m}$ asl) was photographed and described after recovery following the SE-Asian peat classification system (Esterle and Ferm, 1994; Wüst et al., 2003). Eight samples of the peat core and three additional samples from basal clay material were selected and sent to the AMS-laboratory at the University of Nürnberg/Erlangen, Germany and Poznan Radiocarbon Laboratory, Poland for radiocarbon dating (Table 2.1).

Table 2.1. AMS radiocarbon dates from SB-B core, calibrated using SHCal13.14C calibration curve (Hogg et al., 2013). Italic font represents samples taken from basal clay mineral. Outliers are in grey.

\begin{tabular}{|c|c|c|c|c|c|}
\hline $\begin{array}{l}\text { Depth } \\
(\mathrm{cm})\end{array}$ & Lab. Code & Material & $\mathrm{pMC}$ & $\begin{array}{l}\text { Radiocarbon dates } \\
\quad\left({ }^{14} \mathrm{C} \text { yr BP }\right)\end{array}$ & $\begin{array}{c}\text { Age } 2 \sigma \\
\text { (cal yr BP) }\end{array}$ \\
\hline 55 & Poz-85957 & Plant remains & $106.44 \pm 0.34$ & modern & modern \\
\hline 74 & Erl-19233 & $\begin{array}{l}\text { Organic samples } \\
\qquad\left(1-2 \mathrm{~cm}^{3}\right)\end{array}$ & $93.38 \pm 0.46$ & $550 \pm 39$ & $529 \pm 33$ \\
\hline 123 & Poz-85958 & Seed & & $1,275 \pm 30$ & $1,142 \pm 75$ \\
\hline 164 & Erl-19232 & $\begin{array}{l}\text { Organic samples } \\
\qquad\left(\sim 1 \mathrm{~cm}^{3}\right)\end{array}$ & $73 \pm 0.37$ & $2,528 \pm 40$ & $2,575 \pm 196$ \\
\hline 167 & Erl-19515 & Charred fragment & $79.74 \pm 0.40$ & $1,819 \pm 40$ & $1,693 \pm 106$ \\
\hline 181 & Erl-19514 & Charred particles & $69.66 \pm 0.39$ & $2,904 \pm 45$ & $2,983 \pm 128$ \\
\hline 201 & Erl-19231 & Seed & $37.97 \pm 0.27$ & $8,441 \pm 62$ & $9,419 \pm 154$ \\
\hline 238 & Erl-19230 & Charred particles & $23.53 \pm 0.19$ & $11,624 \pm 66$ & $13,409 \pm 145$ \\
\hline 241 & Erl-19229 & Bulk sediment $\left(\sim 2 \mathrm{~cm}^{3}\right)$ & $9.22 \pm 0.12$ & $19,151 \pm 109$ & $23,018 \pm 388$ \\
\hline 305 & Erl-19513 & $\begin{array}{l}\text { Organic bulk sediment } \\
\qquad\left(1-2 \mathrm{~cm}^{3}\right)\end{array}$ & $15.18 \pm 0.20$ & $15,146 \pm 105$ & $18,354 \pm 303$ \\
\hline 347 & Erl-19228 & Bulk sediment $\left(\sim 2 \mathrm{~cm}^{3}\right)$ & $22.48 \pm 0.32$ & $11,991 \pm 115$ & $13,796 \pm 299$ \\
\hline
\end{tabular}

\subsubsection{Palynological analysis}

A palynological analysis was conducted to reconstruct past vegetation in the Sungai

Buluh peatland. Samples for palynological analysis were taken at $10 \mathrm{~cm}$ intervals along 
the core. A total of 35 subsamples were processed following standard methods (Faegri and Iversen, 1989). Two tablets of Lycopodium spores were added as marker to each subsample prior to pollen extraction in order to calculate the pollen and spores concentrations. Pollen and spores were identified using the reference collection of pollen and spores of the Department of Palynology and Climate Dynamics, University of Göttingen, and other available literature (e.g. Anderson and Muller, 1975; Supiandi and Furukawa, 1986; Cole et al., 2015; Jones and Pearce, 2015; Pollen and Spore Image Database of the University of Goettingen - available at http://gdvh.uni-goettingen.de/). Counting of pollen and spore grains was conducted up to a sum of 300 pollen grains. Pollen and spore concentrations were calculated as grains $\mathrm{cm}^{-3}$.

The pollen taxa were grouped into the categories of "mixed-riverine forest" (MRF), representing pollen produced by lowland and riverine plants; "peat swamp forest" (PSF), representing pollen of plants commonly found in peat swamp forest; "open vegetation" (OV), representing pollen produced by herbaceous plants; "ubiquitous" (UQ), representing pollen of plants which do not have a specific ecological distribution; and "mangrove" (MG) which represents pollen produced by salt tolerant plants (e.g. Soerianegara and Lemmens, 1994; Lemmens et al., 1995; Sosef et al., 1998; Padmanaba and Sheil, 2014; Cole et al., 2015). The pollen diagram was prepared with the program C2 (Juggins, 2007).

\subsubsection{Stable carbon isotope and Loss-On-Ignition (LOI) analysis}

Stable organic carbon isotope $\left(\delta^{13} \mathrm{C}_{\mathrm{org}}\right)$ analysis was undertaken to trace the source of OM and change in environmental conditions (Khan et al., 2015). In total, 69 samples were taken along the SB core, dried at $60^{\circ} \mathrm{C}$ for 48 hours and finely ground. Samples were subsequently weighed ( 1-1.5 mg) and treated with $1 \mathrm{~N} \mathrm{HCl}$ to remove carbonates 
prior to the analysis of organic carbon content $\left(\mathrm{C}_{\text {org }}\right)$. Determination of $\mathrm{C}_{\text {org }}$ was done using high temperature oxidation in a Euro EA3000 elemental analyzer. A similarly treated sample was used for determination of $\delta^{13} \mathrm{C}_{\text {org }}$ in a Thermo Finnigan Delta Plus gas isotope ratio mass spectrometer after high temperature combustion in a Flash 1112 EA elemental analyzer. The $\delta^{13} \mathrm{C}_{\text {org }}$ is reported as per mil (\%o) deviation from the carbon isotope composition of the Vienna Pee Dee Belemnite (VPDB) with $\pm 0.1 \%$ uncertainty of each measurement.

LOI analysis was conducted to determine the OM content of the peat. A total of 47 samples were taken along the peat section, weighed and dried at $105^{\circ} \mathrm{C}$ for $24 \mathrm{~h}$. It was then combusted at $550^{\circ} \mathrm{C}$ for $4 \mathrm{~h}$. The OM content (\%) was calculated using following equation:

$$
O M_{L O I}=\left(\frac{d r y \text { weight after } 105^{\circ} \mathrm{C}-\text { weight after combustion }}{d r y \text { weight after } 105^{\circ} \mathrm{C}}\right) \times 100
$$

\subsubsection{Carbon accumulation rate}

To quantify peat bulk density, 92 samples were taken along the core in $2.5 \mathrm{~cm}$ interval (except for the interval of $185-200 \mathrm{~cm}$, where a $5 \mathrm{~cm}$ interval was applied due to insufficient amount of material) and dried overnight at $105^{\circ} \mathrm{C}$ (reported as $\mathrm{g} \mathrm{m}^{-2}$; Chambers et al., 2011). Replications were performed on 16 of the 92 samples. Additionally, 92 subsamples were taken at the same depths and analyzed for total organic carbon content $\left(\mathrm{C}_{\text {org }}\right)$ following the same procedure as in Section 3.2. The $\mathrm{C}$ accumulation rate $\left(\mathrm{g} \mathrm{C} \mathrm{m}^{-2} \mathrm{yr}^{-1}\right)$ was calculated by multiplying the bulk density with total $\% \mathrm{C}_{\text {org }}$ and the rate of peat accumulation per sample as determined based on the age-depth model $\left(\mathrm{cm} \mathrm{yr}^{-1}\right)$. LORCA, which represents the average of carbon accumulation rate between basal age and peat surface (Tolonen and Turunen, 1996), 
was calculated by multiplying the average rate of peat accumulation with median dry bulk density and median $\mathrm{C}_{\text {org }}$ content following the equation used by Page et al. (2004).

\subsubsection{Macro-charcoal analysis}

In order to understand the past fire regime and its correlation to vegetation and peat carbon dynamics, macro-charcoal analysis was performed. Subsamples of $1 \mathrm{~cm}^{3}$ were taken continuously at $0.5 \mathrm{~cm}$ intervals from the core at depths of $240-180 \mathrm{~cm}$ and in 1 $\mathrm{cm}$ intervals from $180-0 \mathrm{~cm}$. Based on the change in sediment/peat accumulation rate, the lower part of the core with the lower accumulation rate was sampled in higher resolution. Each sample was prepared following the method developed by Rhodes (1998) and Stevenson and Haberle (2005). Weak hydrogen peroxide $\left(6 \% \mathrm{H}_{2} \mathrm{O}_{2}\right)$ was used to remove $\mathrm{OM}$ in the sediment and particles $>125 \mu \mathrm{m}$ were retained after gentle wetsieving. All charcoal particles $>150 \mu \mathrm{m}$ were counted under a stereomicroscope and concentrations were calculated as particles $\mathrm{cm}^{-3}$. Fire regime characteristics were identified using CharAnalysis (Higuera et al., 2009; detail parameters explained in Supplementary 1)

\subsubsection{Statistical analysis}

Principal Component Analysis (PCA) was carried out using R to assess a possible relationship between vegetation community composition and the peat $\mathrm{C}$ accumulation rate. The PCA was performed on pollen and spore percentage, $\mathrm{C}$ accumulation rate, peat accumulation rate, organic $\mathrm{C}$ content and peat bulk density. Square root data transformation was applied to pollen and spore percentage data prior to the ordination to minimize the effect of over-represented taxa in the record due to the difference in pollen productivity and dispersal rate among taxa. For instance, the insect-pollinated plants, 
Callophyllum and Shorea (Lemmens and Bunyapraphatsara, 2003; Masuda et al., 2013) must have produced fewer amounts and have had a more limited dispersal of pollen than anemophilous taxa like Moraceae-Urticaceae (Haselhorst et al., 2013).

\subsection{Results}

\subsubsection{Stratigraphy}

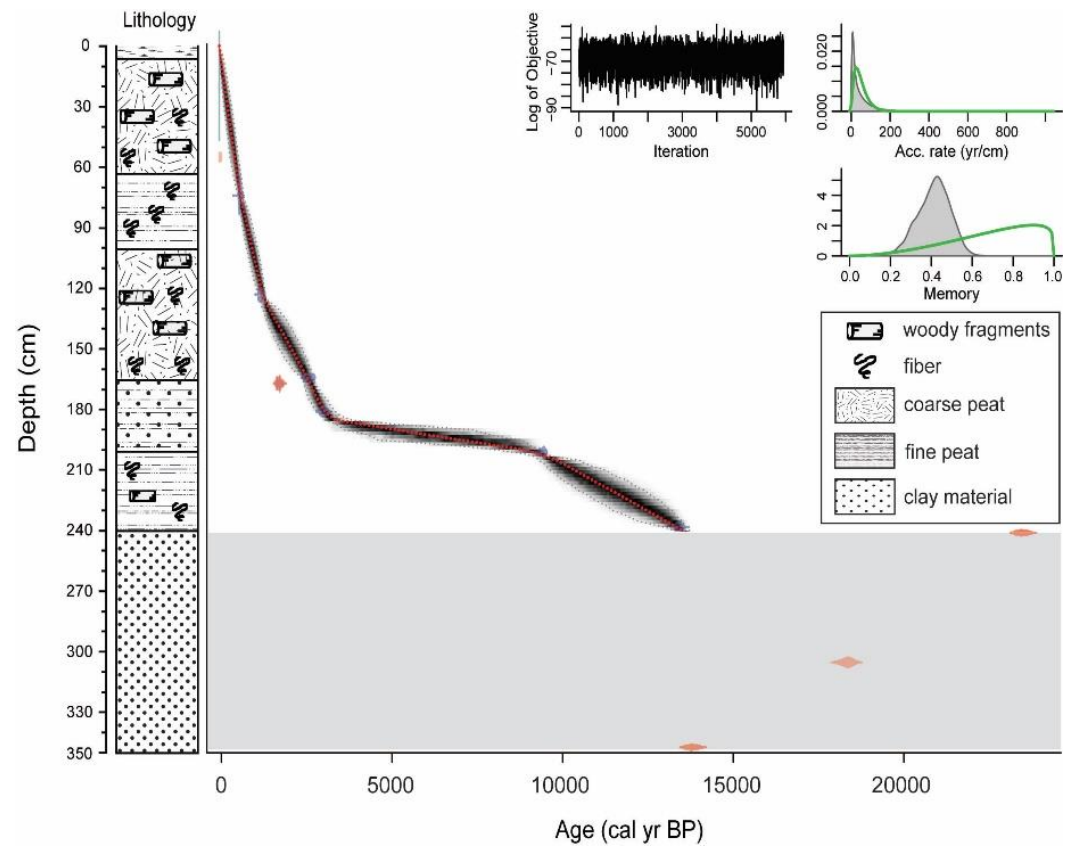

Fig. 2.2. Lithological profiles and age-depth model of SB-B core. The age depth model was constructed with Bacon script (Blaauw and Christen, 2011) in R using SHCal13 calibration curve. The central dotted red line represents the 'best' model based on the weighted mean age, while the outer grey dotted lines indicate $95 \%$ confidence inteval. Outliers and excluded dates are in red.

The $350 \mathrm{~cm}$-long SB-B core consist of a peat layer and underlying mineral clay. The mineral substrate (350 to $240 \mathrm{~cm}$ ) consists mostly of grayish brown to light olive brown clay, whereas the peat layer spans from $240 \mathrm{~cm}$ to the top of the core. The peat layer was further divided into coarse and fine hemic peat according to the size of the fragments and the availability of woody material, with an inserted clayey-peat layer in the depth interval of 200 to $165 \mathrm{~cm}$ (Fig. 2.2).

According to the results of LOI analysis, the organic matter of Sungai Buluh core can be classified as "muck" (LOI= 44\%) from 240-235 cm and "peat" (LOI >45\%) from 230 cm onward to the top (Wüst et al., 2003). 


\subsubsection{Radiocarbon chronology}

The AMS radiocarbon dating results (Table 2.1) show that SB-B core comprises peat depositional history from ca. 13,400 cal yr BP to the present. The age-depth model is constructed using the Bayesian accumulation model, Bacon (Blaauw and Christen, 2011) script in $\mathrm{R}$ ( $\mathrm{R}$ Core Team, 2014), using SHCal13 calibration curve (Fig. 2.2). Radiocarbon dates of samples taken from the clay part of the SB-B core are excluded from the analysis. Using a robust Student's T method (Christen and Pérez, 2009), 'Bacon' identified the samples at 55 and $167 \mathrm{~cm}$ as outliers. Both samples may have been a part of root that intruded into older material in the deeper layer. Wüst et al., (2008) stated that root contamination may result in several hundred years younger than other OM that deposited together in the peat matrix. In the Tasek Bera peatland, for example, modern roots were even found in $2 \mathrm{~m}$ depth (Wüst et al., 2003). The possibility of hiatus in the record between 200 and $165 \mathrm{~cm}$ was ruled out as there is no indication observed in both lithology and pollen data.

\subsubsection{Palynological results}

The record is divided into four palynological zones based on agglomeration using constrained cluster analysis (CONISS; in Supplementary 2; Grimm, 1987) of pollen and spore data along the core (Fig. 2.3): SB-I (240-150 cm; 13,400-2,000 cal yr BP), SB-II (150-112.5 cm; 2,000-1,200 cal yr BP), SB-III (112.5-57.5 cm; 1,200-400 cal yr BP) and SB-IV (57.5-0 cm; $400 \mathrm{cal}$ yr BP to present). Zone SB-I is further divided into SBIa (240-200 cm; 13,400-9,000 cal yr BP) and SB-Ib (200-150 cm; 9,000-2,000 cal yr BP) following the change in lithology (clayey-peat; Fig. 2.2). The pollen concentrations are high in zone SB-I with an average of ca. 300,000 grains $\mathrm{cm}^{-3}$ and are lower in zone SBII to -IV with an average of ca. 30,000 grains $\mathrm{cm}^{-3}$. 
The pollen assemblage of zone SB-I is dominated by riverine taxa (average 41\%; all following \% values are also averages), primarily Macaranga (9\%), Antidesma (4\%), and Nauclea (4\%). Pollen of PSF taxa is also well represented like Calophyllum (3\%), Stemonuraceae (5\%), and Shorea (4\%). In zone SB-II, total pollen of riverine taxa decrease, especially Macaranga (3\%) and Antidesma (1\%), while PSF pollen taxa such as Stemonuraceae (10\%) and Shorea (from 6\%) become more abundant. In the end of zone SB-II, the total of PSF pollen reaches its maximum value (69\%). In zone SB-III, the total pollen values of PSF decrease to $50 \%$ whereas pollen of open vegetation increase to $25 \%$ marked by the increase of Piperaceae (from $1 \%$ in SB-II to $5 \%$ ), Ardisia (from $1 \%$ in SB-II to 6\%), Poaceae (from 2\% in SB-II to $8 \%$ ) and Grewioidea (from $1 \%$ in SB-II to 5\%). In the end of SB-III both Poaceae and Grewioidea reach their maximum values $(16 \%$ and $7 \%)$. In zone SB-IV, the total value of PSF pollen reincreased (60\%) such as Stemonuraceae (12\%), Calophyllum (9\%), Durio (3\%), Garcinia (6\%) and Ficus (3\%). At the end of this last zone, the values of Stenochlaena (15\%) and Nephrolepis (11\%) are markedly higher. Mangrove pollen of Sonneratia and Rhizophoraceae are present with low values in all zones (3\%).

\subsubsection{Biogeochemistry}

From $240 \mathrm{~cm}(13,400 \mathrm{cal} \mathrm{yr} \mathrm{BP}), \mathrm{C}_{\text {org }}$ increases from 22 to $46 \%$ until the depth of 200 cm (ca. 10,000 cal yr BP) and displays little variation around an average of $52 \%$ until the top of the core (Fig. 2.4). $\delta^{13} \mathrm{C}_{\text {org }}$ ranges from $-30.3 \%$ to $-29.0 \%$ from the bottom of the core up to the depth of $170 \mathrm{~cm}$ (ca. 1,700 cal yr BP) and remains stable around $30 \%$ until the top of the core (Fig. 2.4). 
Chapter 2 - Environmental and carbon dynamics of coastal peatland

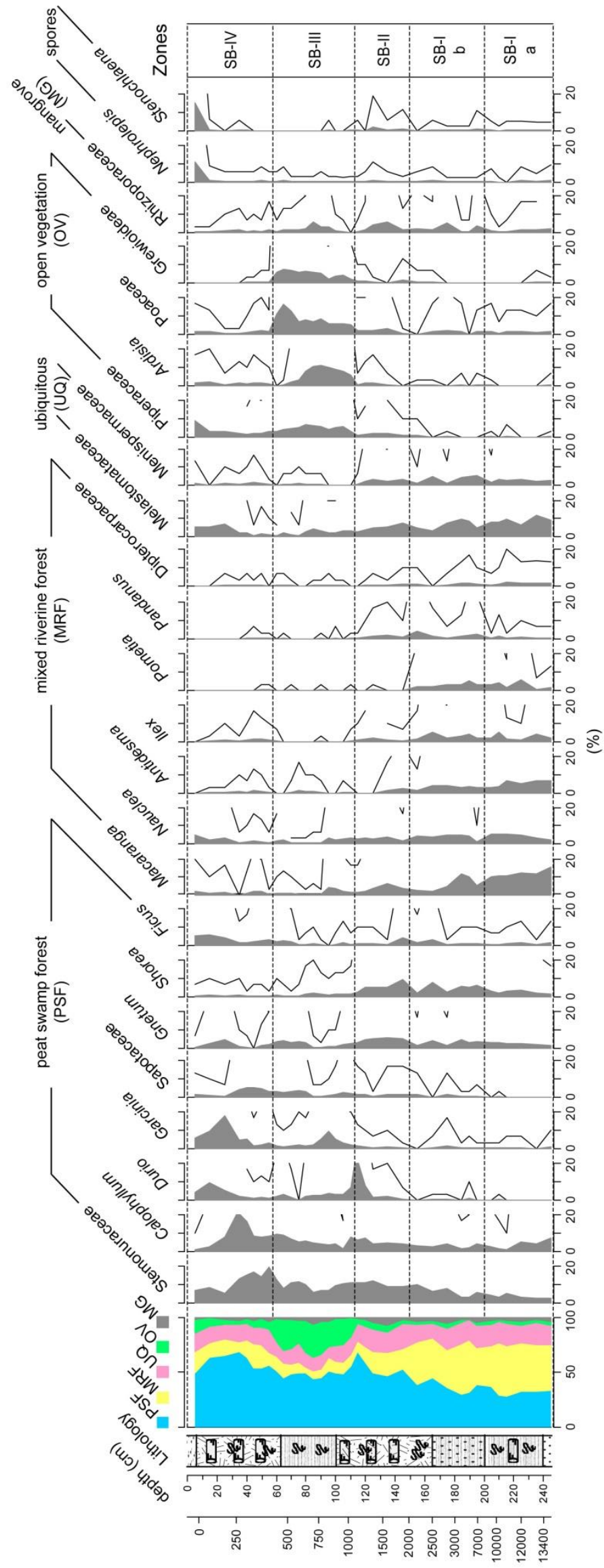

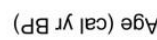

2.4.5. Peat and carbon accumulation rate

From $240-180 \mathrm{~cm}(13,400$ to

3,000 cal yr BP), the peat and

$\mathrm{C}$ accumulation rate are low (average $0.1 \mathrm{~mm} \mathrm{yr}^{-1}$ and $13 \mathrm{~g}$ $\left.\mathrm{C} \mathrm{m}^{-2} \mathrm{yr}^{-1}\right)$. Both rates increase

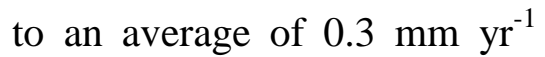
and $34 \mathrm{~g} \mathrm{C} \mathrm{m}^{-2} \mathrm{yr}^{-1}$ from 180 $120 \mathrm{~cm}(3,000-1,200$ cal yr BP). From $120-75 \mathrm{~cm}(1,200$ to 570 cal yr BP), both rates markedly increase to an average of $0.8 \mathrm{~mm} \mathrm{yr}^{-1}$ and 62 $\mathrm{g} \mathrm{C} \mathrm{m}^{-2} \mathrm{yr}^{-1}$. From 75 to $55 \mathrm{~cm}$ (570 to 400 cal yr BP), the peat and $\mathrm{C}$ accumulation rates rise to $1.1 \mathrm{~mm} \mathrm{yr}^{-1}$ and $91 \mathrm{~g} \mathrm{C} \mathrm{m}^{-2}$ $\mathrm{yr}^{-1}$. Both then increase to an average of $1.23 \mathrm{~mm} \mathrm{yr}^{-1}$ and $100 \mathrm{~g} \mathrm{C} \mathrm{m}^{-2} \mathrm{yr}^{-1}$ from $55 \mathrm{~cm}$ to the top part of the core (400 cal yr BP to present; Fig. 2.4). 


\subsubsection{Macro-charcoal and fire regime}

In zone SB-I, the average concentrations of macro-charcoal (Fig. 2.4) is 90 particles per $\mathrm{cm}^{3}$. The concentration is lower in zones SB-II and SB-III $(150-57.5 \mathrm{~cm} ; 2,000-400 \mathrm{cal}$ $\mathrm{yr} \mathrm{BP})$, and higher in zone SB-IV $(57.5-0 \mathrm{~cm} ; 400 \mathrm{cal} \mathrm{yr}$ BP to present). The results of CharAnalysis show that the fire frequency in Sungai Buluh was relatively low along the record with an average of 2 fire events in 1,000 years. It reaches its highest frequency at around 12,000 cal yr BP with 5 fire events in 1,000 years. High magnitude of fire peaks (>100 particles per peak) are more frequent in zone SB-I (3 peaks).

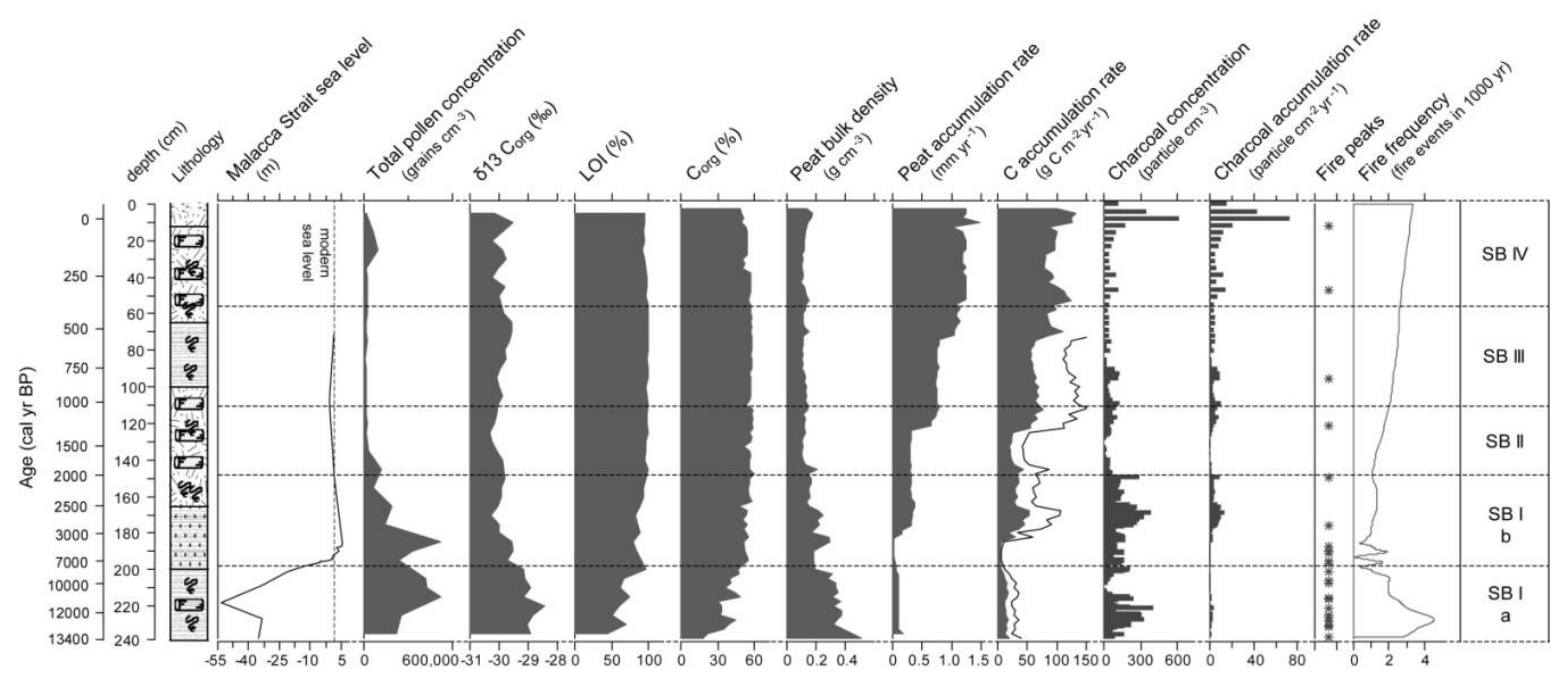

Fig. 2.4. Diagram of total pollen concentration, $\delta 13 \mathrm{C}_{\text {org }}$, LOI, $\mathrm{C}_{\text {org }}$ content, peat bulk density, peat accumulation rate, $\mathrm{C}$ accumulation rate and charcoal analysis results. Malacca Strait sea level change data after Geyh et al. (1979).

\subsubsection{Statistical analysis}

The variance of pollen data is expressed by the PCA (Fig. 2.6A) with PC1 and PC2 explaining about $41 \%$ and $10 \%$ of variance, respectively. The result shows a good separation between sample group 1 and 2 according to PC1. The eigenvector shows that $\mathrm{C}$ accumulation rate is positively correlated to the peat accumulation rate, $\mathrm{C}_{\text {org }}$ and sample group B, and negatively correlated to bulk density and depth. 
In order to have more clear relationship pattern between vegetation community and peat $\mathrm{C}$ accumulation rate, the PCA was again performed on sample group 2. Exclusion of rare taxa, whose average appearance in all samples was $<1 \%$, was done prior to the ordination to minimize the noise. The result from PCA group 2 was then further plotted $\mathrm{C}$ accumulation rate. The vector representing $\mathrm{C}$ accumulation rate is positively correlated with Freycinetia, Myrtaceae, Calophyllum, Stemonuraceae, Ficus and Euphorbiaceae (Fig. 2.6B).

\subsection{Discussion}

\subsubsection{The dynamics of peatland and carbon accumulation rate}

\section{A. Initiation phase}

In Indonesia, peatlands in the coastal area mostly developed around the stabilization of sea-level or 7,000 cal yr BP (Dommain et al., 2011, 2014). However, based on radiocarbon dating results (Fig. 2.2), the accumulation of OM in Sungai Buluh started earlier in the late Glacial around 13,400 cal yr BP. Early initiation of peatland in the coastal area was also reported from Palangkaraya deposit, Central Kalimantan. The Palangkaraya peatland formed around $10,000 \mathrm{yr} \mathrm{BP}$ on a podzol soil, as a result of increased groundwater due to sea-level rise (Neuzil, 1997; Page et al., 2010). It was reported that due to its slightly higher elevation (10-20 $\mathrm{m}$ asl), the inundation from sea level rise, even the sea level highstand (ca. 4,500 cal yr BP; +5.8 m asl; Geyh et al., 1979) did not interrupt the accumulation of OM in Palangkaraya (Neuzil, 1997).

During phases of rapid rise of sea-level around 15,000 to 7,400 cal $\mathrm{yr} \mathrm{BP}$, early development of peatlands at the low elevation of the coastal areas was not possible as marine transgression would persistently disrupt the accumulation of OM (Hanebuth et al., 2000; Page et al., 2004; Dommain et al., 2014). On the other hand, at higher 
elevation, marine transgression and coastal inundation would not exert such an impact and therefore the peat could accumulate earlier (Neuzil, 1997; Page et al., 2004; Dommain et al., 2014). As in Palangkaraya site, the Sungai Buluh peatland was also deposited at a slightly higher elevation area $(9-25 \mathrm{~m}$ asl). Thus, it is plausible that the early initiation date of Sungai Buluh peatland was related to its higher elevation.

Although some studies suggest that most peatlands in coastal area in Indonesia are developed over mangrove or marine sediment (Anderson and Muller, 1975; Supiandi, 1988), the $\delta^{13} \mathrm{C}_{\text {org }}$ result ( 28\%) from Sungai Buluh suggests that the basal clay material was of terrestrial origins (Meyers, 1994). As seen from the case of Kutai peatland, Borneo ( $85 \mathrm{~km}$ inland; $24 \mathrm{~m}$ asl), a marine basal clay is not always a requirement for peatland development in coastal areas (Hope et al., 2005). Kutai peatland reportedly developed over a basal clay layer sourced from the river as suggested by the dominance of kaolin (Hope et al., 2005). The OM accumulation of Kutai peatland took place on a floodplain lake infilled by river impediment due to the rising sea level around 8,000 years ago (Hope et al., 2005).

Similar to Kutai peatland, it is also very much unlikely that the underlying clay mineral in Sungai Buluh was of marine origin. At the time when the accumulation of $\mathrm{OM}$ in Sungai Buluh started around 13,400 years ago, the sea level was $38 \mathrm{~m}$ lower than today (Geyh et al., 1979; Hanebuth et al., 2000) and the site was over $300 \mathrm{~km}$ from the shoreline (Sathiamurthy and Voris, 2006). Considering such conditions, the distribution of marine sediments by coastal inundation to Sungai Buluh site would be very unrealistic.

Additionally, the result from pollen analysis suggests that during the initiation process, the vegetation was dominated by Macaranga, Myrtaceae, Nauclea, Pometia and 
Antidesma, which commonly are found along rivers. It is, therefore, conceivable that in the case of Sungai Buluh, the OM accumulated on a floodplain depression that was filled by a river impediment and/or rising water table due to the rapid sea level rise. This is further confirmed by the presence of reworked material in the basal clay which is commonly found in floodplains (Fig. 2.2; Bridge, 2003).

\section{B. Topogenous phase (Zone SB-Ia)}

From 12,500 to 9,000 cal yr BP, the LOI result suggests that the peat formed in Sungai Buluh can be classified as topogenous peat (LOI $\leq 75 \%$; Anderson, 1961; Fig. 2.4), while pollen analysis indicates that the peat-forming vegetation in Sungai Buluh was dominated by mixed-riverine forest (Fig. 2.3). During its topogenous phase, the accumulation rate of peat and $\mathrm{C}$ of Sungai Buluh were low (average $0.1 \mathrm{~mm} \mathrm{yr}^{-1}$ and 15 $\mathrm{g} \mathrm{C} \mathrm{m}^{-2} \mathrm{yr}^{-1}$; Fig. 2.4).

Globally, it is agreed that the accumulations of peat and $\mathrm{C}$ in peatlands, which depend on the balance between plant production and OM decay, require a relatively stable water level (Keddy, 2000; Limpens et al., 2008; Schumann and Joosten, 2008; Hirano et al., 2009). Fluctuations in the water table could lead to faster aerobic OM decomposition by increasing the oxygen supply (Schumann and Joosten, 2008; Hirano et al., 2009; Sinsabaugh, 2010). Floodplains are ecosystems characterized by a strongly fluctuating water table (van Geest et al., 2005) that is related to several factors such as river stage, distance from the river, rainfall and flood events (Keddy, 2000; Jung and Burt, 2004; van Geest et al., 2005). Taking into consideration that Sungai Buluh peatland is located in a floodplain area, it is likely that the slow peat and $\mathrm{C}$ accumulation of Sungai Buluh between 13,400 and 9,000 cal yr BP resulted from rapid decay of OM due to a strongly fluctuating water table. 
Between 9,000 and 2,500 cal $\mathrm{yr} \mathrm{BP}$, there was a deposition of clayey peat material in Sungai Buluh, whereas the proportion of mixed-riverine vegetation gradually decreased towards the present, except for Pandanus which is commonly found colonizing submerged or flooded river banks (Laumonier, 1997). In the early Holocene, there was a period of ineffective drainage due to channel filling following the rapid increase of sea level in Sundaland (Hanebuth, 2000; Hanebuth and Stattegger, 2003). The rise of sea level caused the river flows to back up and overflow their banks. Such a period of ineffective drainage later continued following the high precipitation in the midHolocene and resulted in reduced river water retention (Partin et al., 2007; Niedermeyer et al., 2014).

Considering that Sungai Buluh is located in a floodplain area, it is conceivable that the deposition of clay was caused by frequent river floods due to ineffective drainage as a result of sea level rise and a period of high precipitation. The river flood transported fine mineral material into the site and resulted in peat accumulation with admixed clay material (Fig. 2.2). Similar conditions were observed in Kutai peatland, Borneo. The abundance of Pandanus pollen in a peaty clay layer was reported to reflect the occurrence of frequent river floods (Hope et al., 2005).

Between 9,000-3,300 cal yr BP, the peat and C accumulation rates of Sungai Buluh were very low (on average $0.03 \mathrm{~mm} \mathrm{yr}^{-1}$ and $5 \mathrm{~g} \mathrm{C} \mathrm{m}^{-2} \mathrm{yr}^{-1}$; Fig. 2.4). As stated by Kozlowski (2002), even for very flood-tolerant trees, floods may impair the cambial growth rate that is responsible for the growth of roots and stems. On the other hand, flooding accelerates $\mathrm{OM}$ decomposition in riparian ecosystems by enhancing the leaching and microbial decomposition of OM by providing moisture and nutrients to the microbial and fungal communities (Brinson, 1977; Limpens et al., 2008; Bragazza et al., 
2012). Thus, low accumulation of peat and $\mathrm{C}$ during 9,000 to $3,300 \mathrm{cal} \mathrm{yr} \mathrm{BP}$ was conceivably related to periodic river floods as a result of ineffective drainage due to sea level rise.

C. Ombrogenous phase (Zone SB-Ia to -IV)

Around 2,500 cal yr BP, there was a gradual change in vegetation cover. Mixed-riverine vegetation e.g. Pandanus and Ilex, was gradually replaced by PSF vegetation such as Stemonuraceae and Durio. Based on pollen analysis, PSF in Sungai Buluh reached its maximum extension around 1,200 cal yr BP. This is Similar to the observation at peatlands in Borneo where the abundance of Pandanus pollen was reported to precede the development of PSF in Kutai and Palangkaraya peatland (Morley, 1981; Hope et al., 2005).

As stated by Branß et al (2016), with every flood that occurred, natural levees grew and limited the input of sediment into the floodplain carried by overbank river flow. Moreover, sea level was reported to have gradually decreased after the highstand $(4,200$ yr BP) and reached the present level at around 1,000 yr BP (Sathiamurthy and Voris, 2006), accompanied by an overall decreased precipitation in Borneo and Sumatra region (Partin et al., 2007). Both might have played a major role in increased river water retention and less flooding events.

In order to maintain riverine vegetation, periodic floods or overbank flows are needed to sustain the nutrient supply into the floodplain system as well as for seed dispersal and groundwater replenishment (Hughes and Rood, 2003). On the other hand, the decay of OM releases organic acids e.g. citrate, oxalate and malate, which consequently increase the acidity of the environment (Whalen and Sampedro, 2010; Posa et al., 2011). This condition is harmful to acid-intolerant riverine vegetation (Hicks et al., 2003). Therefore, 
fewer flooding events and an increasing acidity in Sungai Buluh might have driven the decline of riverine vegetation.

Following the change in vegetation composition at around 2,500 cal yr BP, peat and $\mathrm{C}$ accumulation rates in Sungai Buluh increased to $0.3 \mathrm{~mm} \mathrm{yr}^{-1}$ and $34 \mathrm{~g} \mathrm{C} \mathrm{m}^{-2} \mathrm{yr}-1$ and approach $0.8 \mathrm{~mm} \mathrm{yr}^{-1}$ and $70 \mathrm{~g} \mathrm{C} \mathrm{m}^{2} \mathrm{yr}^{1}$ around the period when the pollen of PSF reached its maximum proportion (Fig. 2.4). As the OM accumulates, the fluctuations in water table decrease (Keddy, 2000). With a more stable groundwater level, the oxygen supply decreased, leading to a decreased rate of aerobic OM decay (Brady, 1997; Hirano et al., 2009). The sea level fall after its highstand and reduced precipitation could also have played an important role as it caused a reduction in river flooding. Fewer river flooding could also have improved the cambial growth and led to increased root and stem biomass production (Kozlowski, 2002). Hence, it is conceivable that rapid peat and $\mathrm{C}$ accumulation in Sungai Buluh is related to a more stable water table due to accumulated $\mathrm{OM}$ and sea level fall. This subsequently led to peat thickening and gave rise to ombrogenous peat.

Between 1,000-450 cal $\mathrm{yr} \mathrm{BP}$, a period of forest opening is indicated by the increasing proportion of Piperaceae, Poaceae, Ardisia and Grewioideae pollen (Fig. 2.3). Around the same period (1,100 to $600 \mathrm{cal} \mathrm{yr} \mathrm{BP})$, an ancient kingdom, Malayu Empire, was reported to be occupying the banks of Batanghari River, approximately $28 \mathrm{~km}$ south of Sungai Buluh peatland. A study by Tjoa-Bonatz et al. (2009) reported that the people of Malayu Empire utilized wood and plant material from the "locally-available abundant resource" to built their settlements. Ergo, it is likely that the forest opening in Sungai Buluh was related to the activities of the inhabitants of Malayu Empire. 
Simultaneously to the forest opening in Sungai Buluh, the $\mathrm{C}$ accumulation rate slightly declined to an average of $60 \mathrm{~g} \mathrm{C} \mathrm{m}^{-2} \mathrm{yr}^{-1}$. According to Gautam and Mandal (2016), reduced forest cover can result in significant decrease in forest productivity and consequently affect the ecosystem ability to accumulate C. Loss in forest cover could also reduce the input of lignin-rich $\mathrm{OM}$ such as wood or branch. This would ease the breakdown of $\mathrm{OM}$ and accelerat $\mathrm{C}$ release through decomposition (Yule et al., 2016).

Moreover, forest opening would also cause a loss of canopy protection for the forest floor. A study from Palangkaraya peatland, Borneo shows that the peat surface temperature of the open peatland area is around $5^{\circ} \mathrm{C}$ higher than in the area with dense forest cover which help enhancing the oxidation process of OM (Ludang et al., 2007; Wüst et al., 2007)

At around $600 \mathrm{cal}$ yr BP, there was an increase of Poacea and Grewioideae pollen accompanied by an increase of Ficus, Calophyllum and Gnetum pollen. Increasing grass commonly indicates the onset of forest regeneration (Kobayashi, 1998; Guariguata and Ostertag, 2001) which is then followed by the growth of rapidly regenerating trees such as Ficus, Calophyllum and Gnetum (Fig. 2.3; Radke and Radke, 1993; Hopewell, 2006; Manner and Elevitch, 2006). Around the same time (ca. $14^{\text {th }}$ century), the Malayu Empire collapsed after being conquered by the Majapahit Kingdom from Java (LocherScholten, 2003 Witrianto, 2014). According to historical records, the so-called "new regime" moved the entire Malayu Empire to the hinterland area of Saruaso (ca. $350 \mathrm{~km}$ from Muara Jambi temple) soon after the conquest. This suggests that the forest recovery in Sungai Buluh was related to the site abandonment.

Following the forest recovery process, the peat and $\mathrm{C}$ accumulation rates of Sungai Buluh increased to averages of $1.1 \mathrm{~m}^{-} \mathrm{yr}^{-}{ }^{1}$ and $92 \mathrm{~g} \mathrm{C} \mathrm{m}^{-2} \mathrm{yr}^{-}$. Both rates increased to 
averages of $1.23 \mathrm{~m}^{-}{ }^{2} \mathrm{yr}^{-}{ }^{1}$ and $100 \mathrm{~g} \mathrm{C} \mathrm{m}^{-}{ }^{2} \mathrm{yr}^{-}{ }^{1}$ after the PSF recovered. During the forest recovery process, the increase of peat and $\mathrm{C}$ accumulation rates might have been related to rapid seedling establishment and rapid fine root biomass accumulation of fast growing saplings (Guariguata and Ostertag, 2001, Feshe et al., 2002). The increase in forest cover would also lead to greater net productivity and simultaneously boost the $\mathrm{C}$ accumulation (Gray et al., 2016). Additionally, an increase in forest cover will raise the supply of lignin-rich OM that might slow down the OM decomposition (Yule et al., 2016).
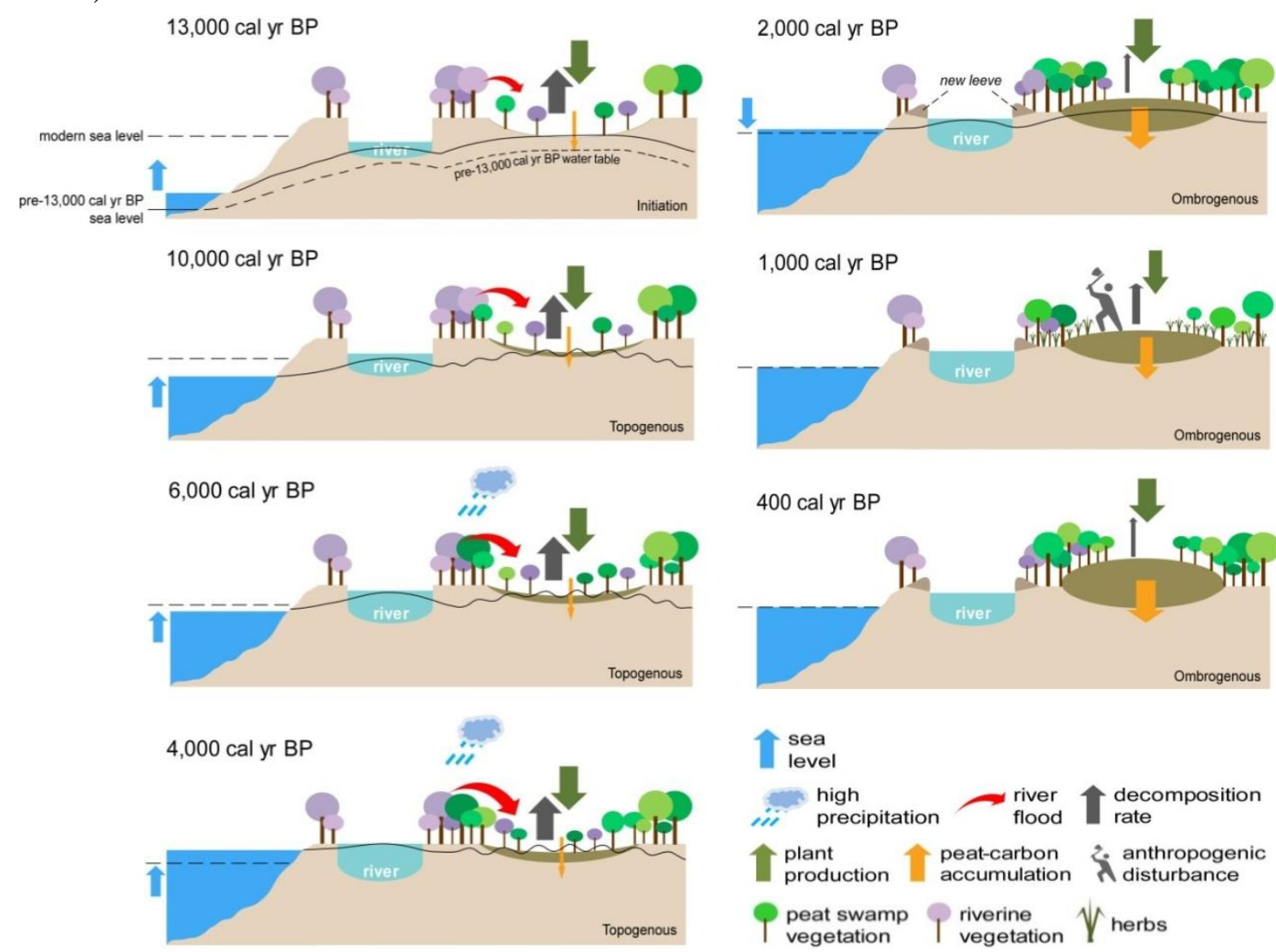

Fig. 2.5. Summary of the carbon accumulation dynamic in relation to the changes in environment. The arrows indicate the direction of the process flow. The thickness of the arrows indicate the magnitude of the process.

\subsubsection{Factors controlling $\mathrm{C}$ accumulation rate}

Peatland $\mathrm{C}$ accumulation is the result of the balance between $\mathrm{OM}$ productivity and decay (Clymo, 1984; Whittle and Gallego-Salla, 2016). This balance can be affected 
and altered by several factors which can be various and site specific. Our palaeoecological analysis indicates that the most important drivers of $\mathrm{C}$ accumulation rates in Sungai Buluh were changes in sea level and river water level, climatic variability, human activities and vegetation dynamics (visualized in Fig. 2.5).

\section{A. Sea level change and river influence}

The influence of sea level and river on the peat $\mathrm{C}$ accumulation rate of Sungai Buluh is in agreement with findings from other tropical peatlands. For example, similar to Sungai Buluh, sea level rise in the early Holocene accommodated the initiation of Palangkaraya peatland.in Borneo (Neuzil, 1997). However, in contrast to Sungai Buluh, sea level regression led to termination of peat and $\mathrm{C}$ accumulation in Palangkaraya peatland around 5,000 years ago. It caused groundwater depletion that subsequently resulted in rapid OM decay (Neuzil, 1997).

The occurrence of river flood in Sungai Buluh resulted in a decreased rate of peat $\mathrm{C}$ accumulation by impairing plant productivity and enhanced OM decay. River influence is also reported to have played an important role in controlling peat and $\mathrm{C}$ accumulation in Pastaza-Marañón, Peru. In lowland Amazonia, river migration interrupted peat accumulation by causing peat erosion in some sites and peat burial on some others (Lähteenoja et al., 2009; 2012).

\section{B. Climate}

Climatic variability is known to play an important role in the dynamics of peat and $\mathrm{C}$ accumulation rates (Page et al., 2004; Dommain et al., 2011; 2014). In Sungai Buluh, enhanced precipitation during the mid-Holocene increased the occurrence of river flood and subsequently reduced peat and $\mathrm{C}$ accumulation rates by reducing productivity and 
enhancing OM decomposition. In Sebangau peatland, Borneo, reduced precipitation between 20,000 and 13,000 cal yr BP resulted in increased OM oxidation that led to a decline in peat and $\mathrm{C}$ accumulation rate (Page et al., 2004).

Reduced precipitation can lead to drought and subsequently cause fires that recently are responsible for massive peat and $\mathrm{C}$ loss (Page et al., 2002). The information regarding past fire activities in tropical peatlands is, however, very sparse (Anshari et al., 2001; Hope et al., 2005; Biagioni et al., 2015; Cole et al., 2015). Only the data from Kutai peatland comprises direct relations of peat $\mathrm{C}$ accumulation and fire. The fire occurrence in Kutai peatland was reported to be related to human activities and El Niño phase (Hope et al., 2005; Dommain et al., 2014).

To better understand the relationship between peat $\mathrm{C}$ accumulation and fire occurrence, macro-charcoal analysis was conducted in Sungai Buluh. It is interesting to see that the past occurrence of fire in Sungai Buluh, with an average of 2 fires per 1,000 years and a maximum frequency of 5 fires per 1,000 years in around 12,000 cal yr BP (Fig. 2.4), was very low compared to the recent fire occurrence of 6-10 fires per year as observed in Palangkaraya peatland (Heil, 2007).

Although not impossible, the probability of charcoal redisposition from the surrounding area is small as long-distance charcoal transportation to the sites can be restricted by the dense-canopy of PSF (Muller, 1963). Therefore, the presence of charcoal in Sungai Buluh likely reflects the occurrence of local fire. However, it is difficult to evaluate to what extent the fire burned in Sungai Buluh and whether it burned only on the tops of the trees or also combusted the peat layer.

In PSF, fire can be ignited from a severe period of drought or by lightning strike on the fire-prone surface such as dried branch or leaves (Hoscilo et al., 2011; Page and Baird, 
2016). Even though a single fire can consume a deep layer of peat, peat swamp forest has a high humidity that acts as fire suppression barrier and protects both forest and the peat surface from burning (Wüst et al., 2007; Wösten et al., 2008; Page and Baird, 2016). Thus, it is very likely that the past fire occurrence in Sungai Buluh did not have a significant impact on peat and $\mathrm{C}$ accumulation. A similar result is also reported from a study in the Air Hitam peatland, Sumatra, where the increase of fire events during the past El Niño years did not affect the peat accumulation (Biagioni et al., 2015).

\section{Human activities}

Past human activities are often related to the occurrence of fire (Anshari et al., 2001; Hope et al., 2005; Hunt and Premanthilake, 2012) which seems not to be the case in Sungai Buluh. Instead, past human activities altered the vegetation composition of Sungai Buluh, which consequently caused a decline in $\mathrm{C}$ accumulation rate due to a reduction in productivity and deposition of more decomposable OM. Due to limited record of past human activities in tropical peatlands, the impact of human activities on peat and $\mathrm{C}$ accumulation rate in Sungai Buluh is difficult to compare. None of the available information on past human activities in the tropics which are inferred from the presence of charcoal directly related to either peat or $\mathrm{C}$ accumulation (Anshari et al., 2001; Hope et al., 2005, Yulianto et al., 2005; Hunt and Premanthilake, 2012).

\section{Vegetation composition}

It has been shown that changes in vegetation composition could result in alteration of $\mathrm{C}$ accumulation (Charman et al., 2015). Based on the PCA analysis, the peat and C accumulation rates of Sungai Buluh peatland are positively correlated to the abundance of Freycinetia, Myrtaceae, Calophyllum, Stemonuraceae, Ficus and Euphorbiaceae (Fig. 
2.6). Such correlation is, however, difficult to explain. We hypothesize that it might be related to the high biomass productivity and/or lignin content of the aforementioned taxa. For example, Calophyllum, Myrtaceae and Ficus are reported to have high lignin content which help impeding decomposition process of OM (Rodrigues et al., 1998;

Dhanya et al., 2013; Yang et al., 2015).

Table 2.2. PCA eigenvectors of pollen sample for depth, bulk density, $\mathrm{C}_{\text {org }}$, peat accumulation rate and $\mathrm{C}$ accumulation rate.

\begin{tabular}{|l|c|c|c|}
\hline \multirow{2}{*}{ Parameter } & \multicolumn{3}{|c|}{ Principal component eigenvector } \\
\cline { 2 - 4 } & PC1 & PC2 & PC3 \\
\hline Depth & -0.90741 & 0.42024 & 0.8828 \\
C $_{\text {org }}$ & 0.99652 & -0.08332 & 0.4274 \\
Bulk density & -0.97579 & 0.21872 & 0.6476 \\
Peat accumulation rate & 0.88081 & -0.47348 & 0.9048 \\
C accumulation rate & 0.88335 & -0.46871 & 0.7851 \\
\hline
\end{tabular}
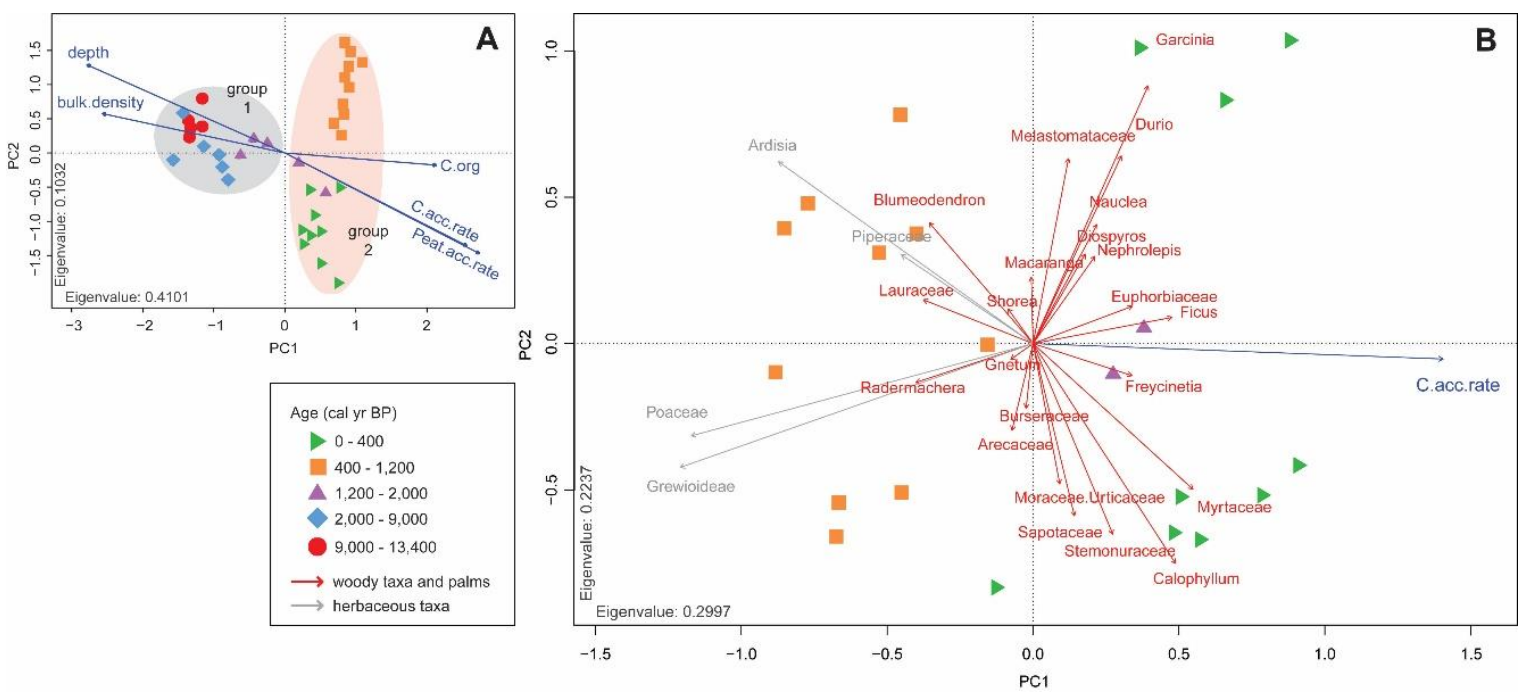

Fig. 2.6. $P C A$ ordination diagram $(\mathrm{PC} 1$ and $\mathrm{PC} 2)$ of Sungai Buluh. The vectors for depth, peat and $\mathrm{C}$ accumulation rate, $\mathrm{C}_{\text {org }}$ and bulk density are indicated by blue arrows radiating from the center (eigenvector values are in Table 2.2). Taxa indincating forest opening are in grey.

\subsubsection{A pantropical comparison}

Compared to other peatlands in tropical regions, the LORCA of Sungai Buluh is moderate (55 $\mathrm{g} \mathrm{C} \mathrm{m}^{-2} \mathrm{yr}^{-1}$; Fig. 2.7). It is lower than for most peatlands in Africa and some sites in SE Asia such as Siak Kanan and Teluk Keramat, but higher in comparison 
to most sites in South America and some other sites in SE Asia such as Air Hitam (Fig.

2.7a).

(a)

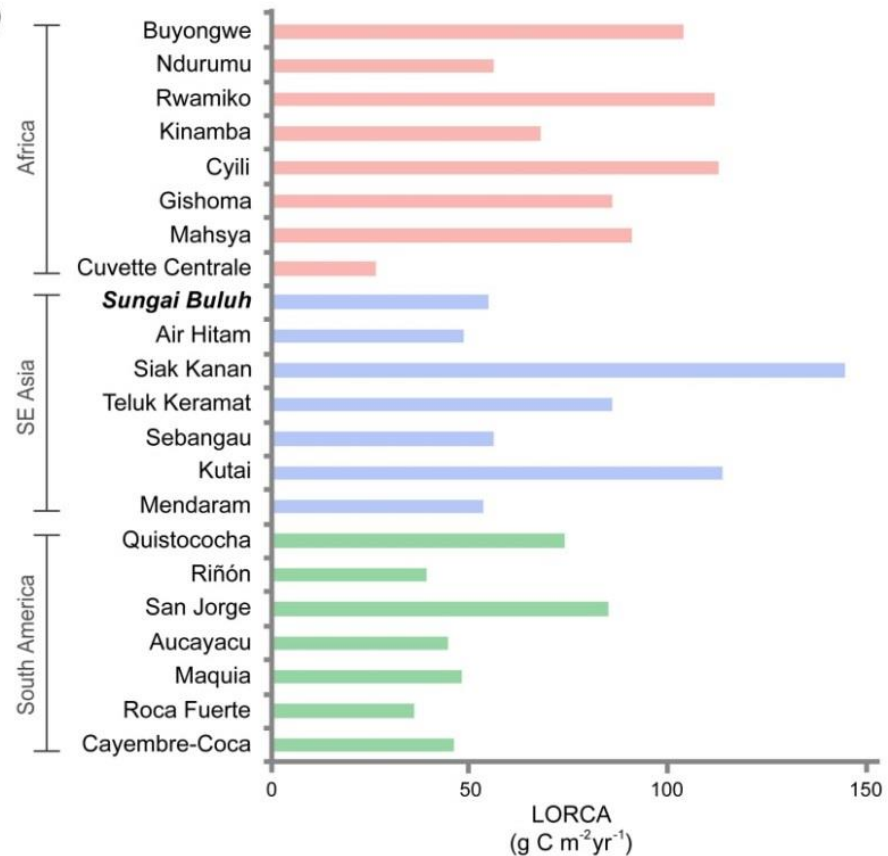

(b)

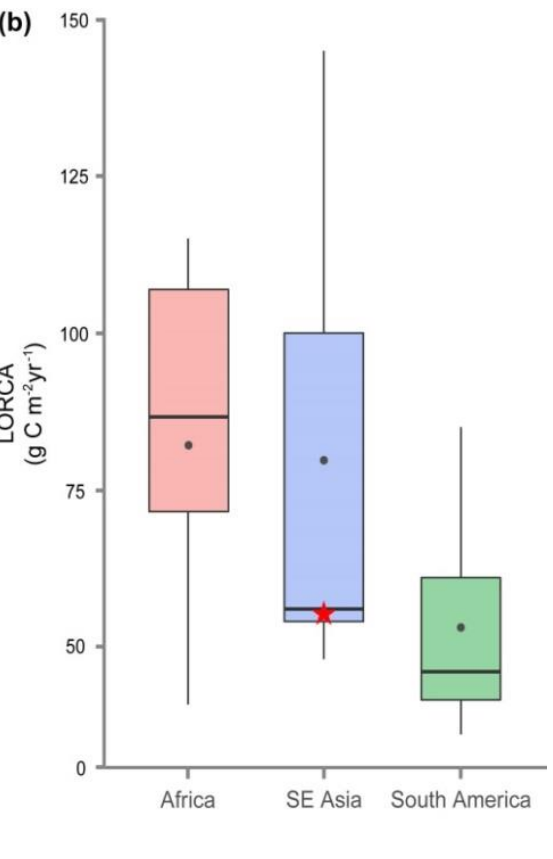

Fig. 2.7. (a) Comparison of LORCA of peatlands in tropical regions since the initiation date (sites correspond to Table 2.3). Different bar colors indicate the regions: blue for SE Asia, green for South America and pink for Africa. (b) LORCA comparison of peatland between the regions. Average values are represented in dark grey dots. Value of Sungai Buluh site is shown in red star symbol.

In Africa, peats are mainly formed by the accumulation of Cyperus papyrus, an herbaceous perennial plant that grows rapidly in swampy areas (Panujen, 1996; Saunders et al., 2013), except for Cuvette Centrale site, Congo where the peats are formed by hardwood vegetation and Raphia palms (Dargie et al., 2017). Meanwhile, SE Asian and South American peatlands are formed mainly by woody vegetation and palms (Anderson and Müller, 1975; Wüst et al., 2003; Lähteenoja and Page, 2011; Biagioni et al., 2015). Cayembre-Coca in Ecuador is an exception, where peat is formed by the accumulation of slow-growing cushion plants (Chimner and Karberg, 2008).

C. papyrus is a fast growing plant with enormous biomass productivity and lignin content (Saunders et al., 2013; Brink and Achigan-Dako, 2012). C. papyrus is also very 
resilient and rapidly mature as it takes only 6 months to reach maturity after aboveground removal due to extensive exploitation (van Dam et al., 2011). Thus it is likely that higher the LORCA in African peatlands is related to the accumulation of $C$. papyrus.

In South America, most peatlands included in this study are strongly influenced by river processes such as meandering, avulsion and migration that can subsequently result in peat erosion (Lähteenoja et al., 2009; 2012). Such process can also cause rapid OM decay due to fluctuating water table resulting from the variation of river water level (Schumann and Joosten, 2008; Lähteenoja and Page, 2011). This might explain why the peat $\mathrm{C}$ accumulation rate in South America is relatively lower than in the other tropical regions.

In SE Asia, the processes that control $\mathrm{C}$ accumulation seem to be more complicated and difficult to generalize. For instance, in Sungai Buluh, the presence of a river and the proximity to the shoreline caused the area to be subject to river inundations that led to slow peat $\mathrm{C}$ accumulation during the period of sea level rise and enhanced precipitation in the early to mid-Holocene. Meanwhile in Siak Kanan, ombrogenous peat rapidly accumulated since the initiation date around 6,000 years ago (Diemont and Supardi, 1987). Similarly, Kutai peatland which initiated around 8,000 years ago has developed to its ombrogenous phase since 6,500 cal yr BP (Hope et al., 2005). The high C accumulation in Siak Kanan and Kutai therefore appears to be related to the long ombrogenous phase.

Nevertheless, it is interesting to see that the $\mathrm{C}$ accumulation rate in upland peatlands of Africa can actually exceed the rates of those located in tropical lowlands. Highland vegetation is commonly lack of woody plants such as tree or tree-like shrubs. Even 
when shrubs are present, they tend to be dwarfed (Mani and Giddings, 1980). Moreover, warmer temperature in lowland areas is often related to the increase of net primary productivity (Yu et al., 2010; Charman et al., 2013).

Table 2.3. List of peatlands in tropical regions compared in this study.

\begin{tabular}{|c|c|c|c|c|c|c|c|c|c|}
\hline No & & Site name & Location & Coordinate & $\begin{array}{c}\text { Altitude } \\
\text { (m asl) }\end{array}$ & $\begin{array}{c}\text { Peat } \\
\text { basal } \\
\text { date } \\
\left({ }^{14} \mathrm{C} \text { yr }\right. \\
\mathrm{BP})\end{array}$ & $\begin{array}{c}\text { Peat } \\
\text { basal } \\
\text { calibrated } \\
\text { age } \\
\text { (cal yr } \\
\text { BP) }\end{array}$ & $\begin{array}{c}\text { Carbon } \\
\text { measure- } \\
\text { ment }\end{array}$ & Reference \\
\hline 1 & & $\begin{array}{l}\text { Sungai } \\
\text { Buluh, } \\
\text { Sumatra }\end{array}$ & coastal & $\begin{array}{c}1^{0} 14^{\prime} \mathrm{S} \\
103^{0} 37^{\prime} \mathrm{E}\end{array}$ & 24 & $\begin{array}{c}11,624 \\
\pm 66\end{array}$ & 13,419 & $\begin{array}{c}\mathrm{C} \\
\text { analysis }\end{array}$ & This study \\
\hline 2 & & $\begin{array}{l}\text { Air } \\
\text { Hitam, } \\
\text { Sumatra }\end{array}$ & inland & $\begin{array}{c}2^{0} 2^{\prime} \mathrm{S} \\
102^{0} 39^{\prime} \mathrm{E}\end{array}$ & 57 & $\begin{array}{c}7,770 \pm \\
101\end{array}$ & 8,562 & $\begin{array}{c}\mathrm{C} \\
\text { analysis }\end{array}$ & $\begin{array}{c}\text { Biagioni } \\
\text { et al., } \\
2015\end{array}$ \\
\hline 3 & & $\begin{array}{l}\text { Siak } \\
\text { Kanan, } \\
\text { Sumatra }\end{array}$ & coastal & $\begin{array}{c}0^{0} 42^{\prime} \mathrm{N} \\
102^{\circ} 01^{\prime} \mathrm{E}\end{array}$ & 8 & $\begin{array}{c}5,220 \pm \\
220\end{array}$ & 5,986 & $\begin{array}{c}\mathrm{C} \\
\text { analysis }\end{array}$ & $\begin{array}{c}\text { Neuzil, } \\
\text { 1997; } \\
\text { Dommain } \\
\text { et al., } \\
2011\end{array}$ \\
\hline 4 & 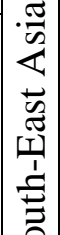 & $\begin{array}{l}\text { Teluk } \\
\text { Keramat, } \\
\text { Borneo }\end{array}$ & coastal & $\begin{array}{c}1^{0} 25^{\prime} \mathrm{N} \\
109^{0} 08^{\prime} \mathrm{E}\end{array}$ & 2 & $\begin{array}{c}4,040 \pm \\
170\end{array}$ & 4,521 & $\begin{array}{c}\mathrm{C} \\
\text { analysis }\end{array}$ & $\begin{array}{c}\text { Neuzil, } \\
1997 ; \\
\text { Dommain } \\
\text { et al., } \\
2011\end{array}$ \\
\hline 5 & ڤ & $\begin{array}{l}\text { Sebanga } \\
\mathrm{u}, \\
\text { Borneo }\end{array}$ & inland & $\begin{array}{c}2^{0} 19^{\prime} \mathrm{S} \\
113^{0} 54^{\prime} \mathrm{E}\end{array}$ & 15 & $\begin{array}{c}22,620 \\
\pm 310\end{array}$ & 26,000 & $\begin{array}{c}\mathrm{C} \\
\text { analysis }\end{array}$ & $\begin{array}{l}\text { Page et } \\
\text { al., } 2004\end{array}$ \\
\hline 6 & & $\begin{array}{l}\text { Kutai, } \\
\text { Borneo }\end{array}$ & inland & $\begin{array}{c}0^{0} 12^{\prime} \mathrm{S} \\
116^{0} 15^{\prime} \mathrm{E}\end{array}$ & 24 & $\begin{array}{c}7,500 \pm \\
220\end{array}$ & 8,285 & $\begin{array}{l}0.064 \mathrm{~g}^{3} \\
\mathrm{C} / \mathrm{cm}^{3} \\
\text { carbon } \\
\text { density }\end{array}$ & $\begin{array}{c}\text { Hope et } \\
\text { al., 2005; } \\
\text { Dommain } \\
\text { et al., } \\
2014\end{array}$ \\
\hline 7 & & $\begin{array}{l}\text { Mendara } \\
\mathrm{m} \text {, } \\
\text { Borneo }\end{array}$ & coastal & $\begin{array}{c}4^{0} 22^{\prime} \mathrm{N} \\
114^{0} 21^{\prime} \mathrm{E}\end{array}$ & 55 & $\begin{array}{c}2,655 \pm \\
35\end{array}$ & 2,776 & $\begin{array}{c}\mathrm{C} \\
\text { analysis }\end{array}$ & $\begin{array}{c}\text { Dommain } \\
\text { et al., } \\
2015\end{array}$ \\
\hline 8 & & $\begin{array}{l}\text { Quistoco } \\
\text { cha, Peru }\end{array}$ & inland & $\begin{array}{c}3^{0} 50^{\prime} \mathrm{S} \\
73^{0} 19^{\prime} \mathrm{W}\end{array}$ & $90-130$ & $\begin{array}{c}2,300 \pm \\
25\end{array}$ & 2,335 & $\begin{array}{c}\mathrm{C} \\
\text { analysis }\end{array}$ & $\begin{array}{l}\text { Lähteenoj } \\
\text { a et al., } \\
2009\end{array}$ \\
\hline 9 & 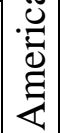 & $\begin{array}{l}\text { Riñón, } \\
\text { Peru }\end{array}$ & Inland & $\begin{array}{c}4^{0} 54^{\prime} \mathrm{S} \\
74^{0} 00^{\prime} \mathrm{W}\end{array}$ & $90-130$ & $\begin{array}{c}1,700 \pm \\
25\end{array}$ & 1615 & $\begin{array}{c}\mathrm{C} \\
\text { analysis }\end{array}$ & $\begin{array}{l}\text { Lähteenoj } \\
\text { a et al., } \\
2009\end{array}$ \\
\hline 10 & 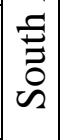 & $\begin{array}{l}\text { San } \\
\text { Jorge, } \\
\text { Peru }\end{array}$ & inland & $\begin{array}{c}4^{0} 03^{\prime} \mathrm{S} \\
73^{0} 11^{\prime} \mathrm{W}\end{array}$ & $90-130$ & $\begin{array}{c}2,850 \pm \\
35\end{array}$ & 2945 & $\begin{array}{c}\mathrm{C} \\
\text { analysis }\end{array}$ & $\begin{array}{c}\text { Lähteenoj } \\
\text { a et al., } \\
2009\end{array}$ \\
\hline 11 & & $\begin{array}{l}\text { Aucayac } \\
\text { u, Peru }\end{array}$ & inland & $\begin{array}{c}3^{0} 56^{\prime} \mathrm{S} \\
74^{0} 23^{\prime} \mathrm{W}\end{array}$ & 124 & $\begin{array}{c}7,963 \pm \\
35\end{array}$ & 8,870 & $\begin{array}{c}\mathrm{C} \\
\text { analysis }\end{array}$ & $\begin{array}{l}\text { Lähteenoj } \\
\text { a et al., }\end{array}$ \\
\hline
\end{tabular}


Chapter 2 - Environmental and carbon dynamics of coastal peatland

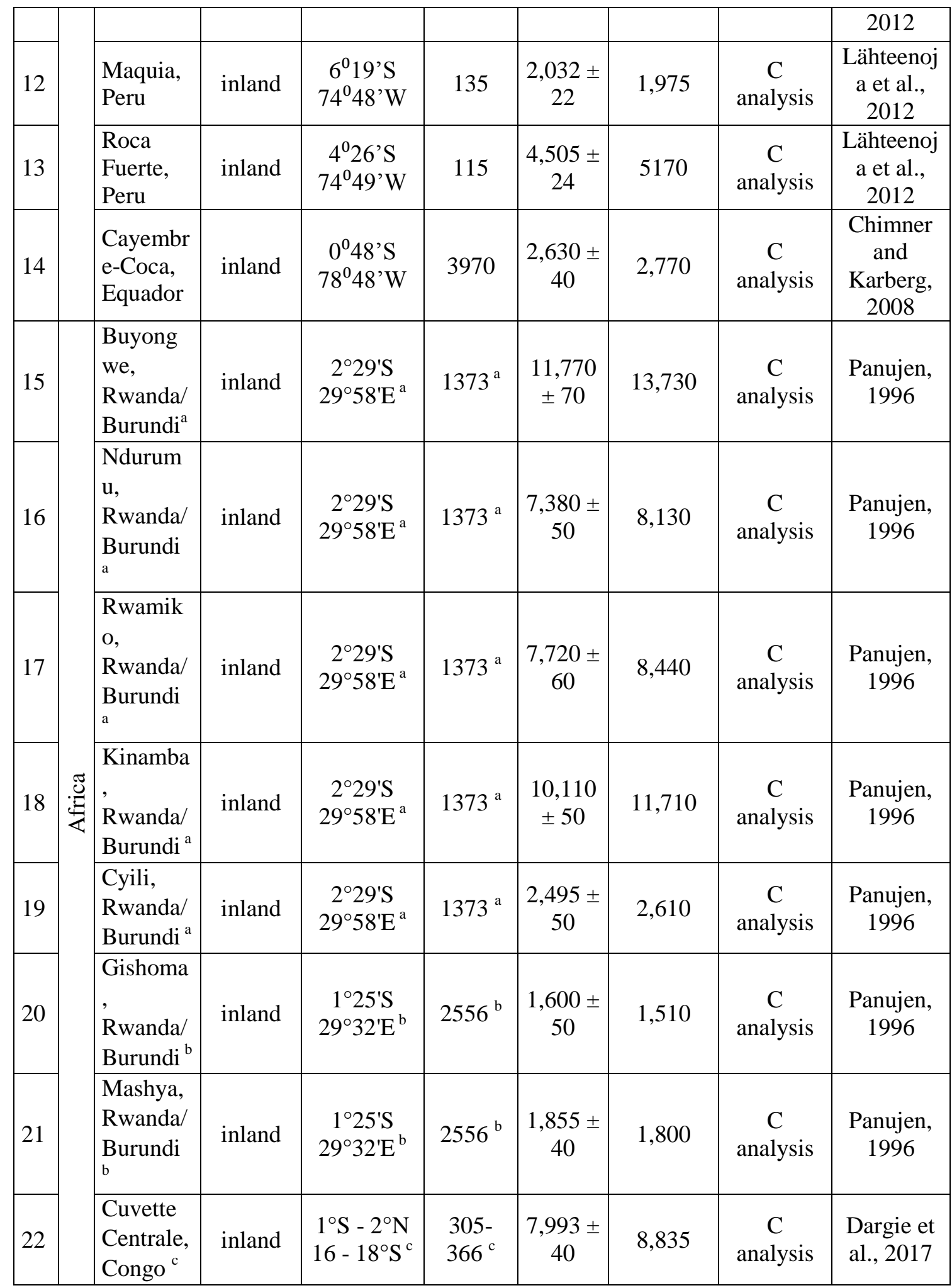

${ }^{\mathrm{a}}$ Coordinate and elevation of Akanyaru swamp complex. The sites are located nearby. The coordinate and elevation of each site is not mentioned.

${ }^{\mathrm{b}}$ Coordinate and elevation of Virunga swamp complex. The sites are located nearby. The coordinate and elevation of each site is not mentioned.

${ }^{\mathrm{b}}$ Coordinate and elevation are in range. 


\subsection{Summary and conclusion}

Our results from the palaeoecological investigation of Sungai Buluh peatland in Central Sumatra revealed that the peatland has developed since its initiation date (ca. 13,400 cal yr BP) from mixed-riverine forest-dominated topogenous peat to peat-swamp forestdominated ombrogenous peat. We also found that the rate of $\mathrm{C}$ accumulation in Sungai Buluh, which varied depending on the balance between the ecosystem productivity and decay, was dynamic overtime and driven mainly by sea level change, river water level, climatic variability, anthropogenic activities and vegetation dynamics.

Such results are in agreement with other studies, although our comparison shows that those factors could be distinct and unique for each site and could impact each site differently. Sea level regression, for instance, resulted in cessation of peat and C accumulation in Palangkaraya, but contrarily led to increased peat and $\mathrm{C}$ in Sungai Buluh. Therefore, it is important to identify the site-specific processes and factors as well as the impacts of different processes and factors on $\mathrm{C}$ accumulation rate.

In Sungai Buluh peatland, the peat and $\mathrm{C}$ accumulation is positively correlated to Freycinetia, Myrtaceae, Calophyllum, Stemonuraceae, Ficus and Euphorbiaceae. This assessment, however, needs to be confirmed by more similar studies as well as supporting ones, such as pollen productivity and dispersal rate studies. In the tropics, such correlation might not be as clear as Sphagnum-peat C accumulation as in the northern peatlands. Regardless, such information is valuable as it can help to set priority-taxa in peat carbon management and peatland restoration project.

Amongst other tropical peatlands globally, Sungai Buluh has moderate LORCA, suggesting a reasonable potential for future global tropical peat $\mathrm{C}$ sequestration. Considering the pressure from rapid economic growth that led to land use conversion 
and natural resource exploitation, its status as a protected area elevates the potential of Sungai Buluh peatland as global tropical carbon sink. However, as many other coastal environments, Sungai Buluh is unlikely to be able to escape the threat and damage of sea level rise owing to warming climate which is predicted to increase around $1.6 \mathrm{~m}$ per century (Rohling et al., 2008; Jevrejeva et al., 2010). The rise of sea level will lead to land inundation and saltwater intrusion that can negatively impact the rate of peat $\mathrm{C}$ accumulation, particularly in SE Asia where most of the peatlands are located in lowland coastal area ( $\leq 5 \mathrm{~m}$ asl; Whittle and Gallego-Salla, 2016). Although direct seawater inundation in Sungai Buluh peatland is very unlikely due to its slightly higher elevation, the history shows that it might be once again affected by river flooding due to the ineffective drainage. Thus, a mitigation of this potential damage on the peatland needs to commence. In the meantime, consideration for priority and alternatives sites for peatland conservation and restoration purpose also needs to be given.

\section{Acknowledgement}

We acknowledge our financial support from the DFG Sonderforschungsbereich in the framework of the collaborative German-Indonesian research project CRC 990 (EFForTS) subproject A01 and Erasmus Mundus Lotus Program. This study was conducted using samples collected under Research Permit No. 1095/FRP/SM/V/2013 recommended by the Indonesian Institute of Science (LIPI) issued by the Ministry of Forestry (PHKA). We thank Dorothee Dasbach (Chemilabor, ZMT Bremen) for supporting the carbon content and stable isotopes measurements and Thomas Giesecke for providing us his expertise in statistical analysis. We also thank Paula Rodríguez and Christoph Peters for their supports and intersting perspectives throughout the writing 
process. Finally, we express our gratitude to the reviewers for their constructive suggestions for improving this manuscript.

\section{References}

Aldrian, E., Susanto, R.D., 2003. Identification of three dominant rainfall regions within Indonesia and their relationship to sea surface temperature. Int. J. Climatol. 23, 1435-1452. doi:10.1002/joc.950

Anderson, J.A.R., 1961. The ecology and forest types of the peat swamp forests of Sarawak and Brunei in relation to their siviculture. Dissertation, Univ. of Edinburgh, UK

Anderson, J.A.R. 1964. The structure and development of the peat swamps of Sarawak and Brunei. Journal of Tropical Geography 18, 7-16.

Anderson, J.A.R., Muller, J., 1975. Palynological study of a Holocene peat and a Miocene coal deposit from NW Borneo. Rev. Palaeobot. Palynol. 19, 291-351. doi:10.1016/0034-6667(75)90049-4

Anshari, G., Kershaw, A.P., van der Kaars, S., 2001. A Late Pleistocene and Holocene pollen and charcoal record from peat swamp forest, Lake Sentarum wildlife reserve, West Kalimantan, Indonesia. Palaeogeogr. Palaeoclimatol. Palaeoecol. 171, 213228. doi:10.1016/S0031-0182(01)00246-2

Biagioni, S., Krashevska, V., Achnopha, Y., Saad, A., Sabiham, S., Behling, H., 2015. $8000 y e a r s$ of vegetation dynamics and environmental changes of a unique inland peat ecosystem of the Jambi Province in Central Sumatra, Indonesia. Palaeogeogr. Palaeoclimatol. Palaeoecol. $\quad 440, \quad 813-829$. http://dx.doi.org/10.1016/j.palaeo.2015.09.048

Birks, H.J.B., 2012. Ecological palaeoecology and conservation biology : controversies, challenges, and compromises. Int. J. Biodivers. Sci. Ecosyst. Serv. Manage. 8, 292304. http://dx.doi.org/10.1080/21513732.2012.701667

Blaauw, M., Christen, J.A., 2011. Flexible paleoclimate age-depth models using an autoregressive gamma process. Bayesian Anal. 6, 457-474

Brady, M.A., 1997. Organic Matter Dynamics of Coastal Peat Deposits in Sumatra, Indonesia. The University of British Columbia.

Bragazza, L., Buttler, A., Habermacher, J., Brancaleoni, L., Gerdol, R., Fritze, H., Hanaji'k, P., Laiho, R., Johnson, D., 2012. High nitrogen deposition alters the decomposition of bog plant litter and reduces carbon accumulation. Glob. Chang. Biol. 18, 1163-1172. doi: 10.1111/j.1365-2486.2011.02585.x

Bragazza, L., Buttler, A., Robroek, B., Albrecht, R., Zaccone, C., Jassey, V., Signarbieux, C., 2016. Persistent high temperature and low precipitation reduce peat carbon accumulation. Glob. Chang. Biol.. doi: 10.1111/gcb.13319

Branß, T., Dittrich, A., Núñez-González, F., 2016. Reproducing natural levee formation in an experimental flume. In River Flow: Constantinescu, Garcia, Hanes (Editors). 
Taylor \& Francis Group, London. ISBN 978-1-138-02913-2.

Bridge, J.S., 2003. Rivers and Floodplains: Forms, Processes, and Sedimentary Record. Blackwell Publishing. Oxford, UK.

Brink, M., Achigan-Dako, E.G. (Editors), 2012. Plant Resources of Tropical Africa 16. Fibres. PROTA Foundation, Wageningen, Netherlands.

Brinson, M., 1977. Decomposition and Nutrient Exchange of Litter in an Alluvial Swamp Forest. Ecology 58(3), 601-609. http://www.jstor.org/stable/1939009

Chambers, F.M., Beilman, D.W., Yu, Z., 2011. Methods for determining peat humification and for quantifying peat bulk density, organic matter and carbon content for palaeostudies of climate and peatland carbon dynamics. Mires and Peat 7 , $1-10$.

Charman, D.J., Beilman, D.W., Blaauw, M., Booth, R.K., Brewer, S., Chambers, F.M., Christen, J.A., Gallego-Sala, A., Harrison, S.P., Hughes, P.D.M., Jackson, S.T., Korhola, A., Mauquoy, D., Mitchell, F.J.G., Prentice, I.C., Van Der Linden, M., De Vleeschouwer, F., Yu, Z.C., Alm, J., Bauer, I.E., Corish, Y.M.C., Garneau, M., Hohl, V., Huang, Y., Karofeld, E., Le Roux, G., Loisel, J., Moschen, R., Nichols, J.E., Nieminen, T.M., MacDonald, G.M., Phadtare, N.R., Rausch, N., Sillasoo, U., Swindles, G.T., Tuittila, E.S., Ukonmaanaho, L., Väliranta, M., Van Bellen, S., Van Geel, B., Vitt, D.H., Zhao, Y., 2013. Climate-related changes in peatland carbon accumulation during the last millennium. Biogeosciences 10, 929-944. doi:10.5194/bg-10-929-2013

Charman, D.J., Amesbury, M.J., Hinchliffe, W., Hughes, P., Mallon, G., Blake, W.H., Daley, T.J., Gallego-Sala, A., Mauquoy, D., 2015. Drivers of Holocene peatland carbon accumulation across a climate gradient in northeastern North America. Quat. Sci. Rev. 121, 110-119. http://dx.doi.org/10.1016/j.quascirev.2015.05.012

Chimner, R.A., Karberg, J.M., 2008. Long-term carbon accumulation in two tropical mountain peatlands, Andes Mountains, Ecuador. Mires and Peat 3, 1-10.

Christen, J.A., Pérez, S., 2009. A new robust statistical model for radiocabron data. Radiocarbon 51(3), 1047-1059.

Clymo, R.S., 1984. The limits to peat bog growth. Philos. Trans. R. Soc Lond. B 303, 605-654. doi:10.1098/rstb.1984.0002

Cole, L.E.S., Bhagwat, S.A., Willis, K.J., 2015. Long-term disturbance dynamics and resilience of tropical peat swamp forests. J. Ecol. 103, 16-30. doi:10.1111/13652745.12329

Couwenberg, J., Dommain, R., Joosten, H., 2010. Greenhouse gas fluxes from tropical peatlands in south-east Asia. Glob. Chang. Biol. 16, 1715-1732, doi: 10.1111/j.1365-2486.2009.02016.x.

Dargie, G.C., Lewis, S.L., Lawson, I.T., Mitchard, E.T.A., Page, S.E., Bocko, Y.E., Ifo, S.A., 2017. Age, extent and carbon storage of the central Congo Basin peatland complex. Nature 542, 86-90. doi:10.1038/nature21048

Dhanya, B., Viswanath, S., Purushothaman, S., 2013. Decomposition and nutrient release dynamics of Ficus benghalensis L. litter in traditional agroforestry systems 
of Karnataka, Southern India. ISRN Forestry Vol. 2013, 524679. http://dx.doi.org/10.1155/2013/524679

Diemont, W.H., Supardi, 1987. Accumulation of organic matter and inorganic constituents in a peat dome in Sumatra, Indonesia. In: International Peat Society Symposium on Tropical Peat and Peatlands for Development, Yogyakarta, Indonesia, February 9-14, 1987, Abstracts, pp. 698-708.

Dommain, R., Couwenberg, J., Joosten, H., 2011. Development and carbon sequestration of tropical peat domes in south-east Asia: Links to post-glacial sealevel changes and Holocene climate variability. Quat. Sci. Rev. 30, 999-1010. doi:10.1016/j.quascirev.2011.01.018

Dommain, R., Couwenberg, J., Glaser, P.H., Joosten, H., Suryadiputra, I.N.N., 2014. Carbon storage and release in Indonesian peatlands since the last deglaciation. Quat. Sci. Rev. 97, 1-32. doi:10.1016/j.quascirev.2014.05.002

Dommain, R., Cobb, A.R., Joosten, H., Glaser, P., Chua, A., Gandois, L., Kai, F., Noren, A., Salim, K., Su'ut, N., Harvey, C., 2015. Forest dynamic and tip-up pools drive pulses of high carbon accumulation rates in a tropical peat dome in Borneo (Southeast Asia). J. Geophys. Res. Biogeosci 120, 617-640. doi:10.1002/2014JG002796

Esterle, J.S., Ferm, J.C., 1994. Spatial variability in modern tropical peat deposits from Sarawak, Malaysia and Sumatra, Indonesia: analogues for coal. Int. J. Coal Geol. 26, 1-41. doi: 10.1016/0166-5162(94)90030-2

Faegri, K., Iversen, J., 1989. In: Textbook of Pollen Analysis, revised by Faegri, K., Kaland, P.E., Krzywinski, K. John Wiley, New York.

Feshe, J., Hofstedea, R., Aguirrea, N., Paladinesa, C., Kooijmanb, A., Sevinka, J., 2002. High altitude tropical secondary forests: a competitive carbon sink? For. Ecol. Manage. 163, 9-25.

Gautam, T.P., Mandal, T.N., 2016. Effect of disturbance on biomass, production and carbon dynamics in moist tropical forest of eastern Nepal. For. Ecosyst. 3, 11. doi: 10.1186/s40663-016-0070-y

Geyh, M.A., Kudrass, H.-R., Streif, H., 1979. Sea-level changes during the late Pleisticene and Holocene in teh Strait of Malacca. Nature 278, 441-443.

Gorham, E. 1991. Northern peatlands role in the carbon-cycle and probable responses to climate warming. Ecol. Appl. 1, 182-195. doi:10.2307/1941811

Gray, A.N., Whittier, T.R., Harmon, M.E., 2016. Carbon stocks and accumulation rates in Pacific Northwest forests: role of stand age, plant community, and productivity. Ecosphere 7(1), e01224. doi: 10.1002/ecs2.1224

Grimm, E.C., 1987. CONISS: A FORTRAN 77 program for stratigraphically constrained cluster analysis by the method of incremental sum of squares. Computers \& Geosciences 13, 13-35.

Guariguata, M.R., Ostertag, R., 2001. Neotropical secondary forest succession: changes in structural and functional characteristic. For. Ecol. Manage., 148(1-3), 185-206. http://dx.doi.org/10.1016/S0378-1127(00)00535-1 
Hanebuth, T., Stattegger, K., Grootes, P.M., 2000. Rapid Flooding of the Sunda Shelf: A Late-Glacial Sea-Level Record. Science 288, 1033-1035. doi:10.1126/science.288.5468.1033

Hanebuth, T.J.J., Stattegger, K., 2003. Depositional sequences on a late PleistoceneHolocene tropical siliciclastic shelf (Sunda Shelf, southeast Asia). J. Asian Earth Sci. 23, 113-126. doi:10.1016/S1367-9120(03)00100-7

Haselhorst,D.S., Moreno, J.E., Punyasena, S.W., 2013. Variability within the 10-Year Pollen Rain of a Seasonal Neotropical Forest and Its Implications for Paleoenvironmental and Phenological Research. PLoS ONE 8(1), e53485. doi: 10.1371 journal.pone.0053485

Heil, A., 2007. Indonesian Forest and Peat Fires: Emissions, Air Quality, and Human Health. Reports on Earth System Science. Dissertation, Department of Geoscience, University of Hamburg-Max Planck Institute for Meteorology.

Hicks, W.S., Fitzpatrick, R.W., Lamontagne, S., Rogers. S., 2003. Risks of water quality degradation during the remediation of floodplain salinity in the River Murray. In: I.C. Roach, Editor, Advances in regolith. CRC LEME, Adelaide, Australia. p. 178-181.

Higuera, P.E., Brubaker, L.B., Anderson, P.M., Hu, F.S., Brown, T.A., 2009. Vegetation mediated the impacts of postglacial climatic change on fire regimes in the south-central Brooks Range, Alaska. Ecol. Monogr. 79, 201-219. doi:10.1890/07-2019.1

Hirano, T., Jauhiainen, J., Inoue, T., Takahashi, H., 2009. Controls on the carbon balance of tropical peatlands. Ecosystems, 12, 873-887.

Hogg AG, Hua Q, Blackwell PG, Niu M, Buck CE, Guilderson TP, Heaton TJ, Palmer JG, Reimer PJ, Reimer RW, Turney CSM, Zimmerman SRH. 2013. SHCal13 Southern Hemisphere calibration, 0-50,000 years cal BP. Radiocarbon 55(4):18891903. doi: 10.2458/azu_js_rc.55.16783

Hope, G., Chokkalingam, U., Anwar, S., 2005. The stratigraphy and fire history of the Kutai Peatlands, Kalimantan, Indonesia. Quat. Res. 64, 407-417. doi:10.1016/j.yqres.2005.08.009

Hopewell, G., 2006. Construction timbers in Queensland: properties and specifications for satisfactory performance of construction timbers in Queensland, Class 1 and Class 10 buildings. Department of Primary Industries and Fisheries, Brisbane.

Hoscilo, A., Page, S.E., Tansey, K.J., Rieley, J.O., 2011. Effect of repeated fires on land-cover change on peatland in southern Central Kalimantan, Indonesia, from 1973 to 2005. Int. J. Wildland Fire 20, 578-588.

Hughes, F.M.R., Rood, S.B., 2003. Allocation of River Flows for Restoration of Floodplain Forest Ecosystems: A Review of Approaches and Their Applicability in Europe. Environ. Manage. 32(1), 12-33. doi: 10.1007/s00267-003-2834-8

Hunt, C.O., Premathilake, R., 2012. Early Holocene vegetation, human activity and climate from Sarawak, Malaysian Borneo. Quat. Int. 249, 105-119. doi:10.1016/j.jas.2007.02.023

Ise, T., Dunn, A., Wofsy, S., Moorcroft, P., 2008. High sensitivity of peat 
decomposition to climate change through water-table feedback. Nat. Geosci. 1, 763766. doi:10.1038/ngeo331

Jevrejeva, S., Moore, J. C., Grinsted, A. 2010. How will sea level respond to changes in natural and anthropogenic forcings by 2100 ? Geophys. Res. Lett. 37, L07703. doi:10.1029/2010GL042947

Jones, S.E., Pearce, K.G., 2015. A pollen morphology study from the Kelabit Highlands of Sarawak, Malaysian Borneo. Palynology 39, 150-204. doi:10.1080/01916122.2014.940472

Jowsey, P.C., 1966. An improved peat sampler. New Phytol. 65, 245-248. doi:10.1111/j.1469-8137.1966.tb06356.x

Juggins, S., 2007. C2 user guide: Software for ecological and palaeoecological data analysis and visualization. University of Newcastle, UK.

Jung, M and Burt, T.P., 2004. Toward a conceptual model of floodplain water table response. Water Resour. Res. 40, W12409. doi:10.1029/2003WR002619

Juutinen, S., Bubier, J.L., Moore, T.R., 2010. Responses of Vegetation and Ecosystem CO2 Exchange to 9 Years of Nutrient Addition at Mer Bleue Bog. Ecosystems 13(6), 874-887.doi: 10.1007/s10021-010-9361-2

Karger, D.N., Conrad, O.,Böhner, J., Kawohl, T., Kreft, H., Soria-Auza, R. W., Zimmermann, N.E., Linder, H.P., Kessler, M., 2016. CHELSA climatologies at high resolution for the earth's land surface areas (Version 1.1). World Data Center for Climate. doi:10.1594/WDCC/CHELSA_v1_1.

Keddy, P.A, 2000. Wetland Ecology: Principles and Conservation. Cambridge University Press, UK.

Khan, N., Vane, C.H., Horton, B.P., 2015. "Stable carbon isotope and C/N geochemistry of coastal wetland sediments as a sea-level indicator". Handbook of Sea-Level Research. Ed. Ian Shennan. John Wiley \& Sons, Ltd., Chichester, pp. 295-311.

Klein, E.S., 2013. Differential response of Alaska peatlands to climate changes of the last millennium. Theses and Dissertation. Paper 1526. Lehigh Preserve, Pennsylvania, United States.

Kobayashi, S., 1998. The Process of Vegetation Recovery in the Exploited Peat Swamp Forest at Sg. Damit, Belait Peat Swamp Forest Reserve. Research Report for the Maintenance and Effective Use of Forest Resources in Negara Brunei Darussalam, Forestry Department, Brunei Darussalam and JICA Forestry Research Project, Brunei, 80-90.

Kozlowski, T.T., 2002. Physiological-Ecological Impacts of Flooding on Riparian Forest Ecosystems. Wetlands 22(3), 550-561. doi: http://dx.doi.org/10.1672/02775212(2002)022[0550:PEIOFO]2.0.CO;2

Laumonier, Y., 1997. The Vegetation and Physiography of Sumatra. Kluwer Academic Publisher, Dordrecht, Netherland.

Lähteenoja, O., Ruokolainen, K., Shulman, L., Oinonen, M., 2009. Amazonian peatlands: an ignored C sink and potential source. Glob. Chang. Biol. 15, 2311-2320. 
doi: 10.1111/j.1365-2486.2011.02504.x

Lähteenoja, O., Page, S., 2011. High diversity of tropical peatland ecosystem types in the Pastaza-Marañón basin, Peruvian Amazonia. J. Geophys. Res. 116, G02025. doi:10.1029/2010JG001508

Lähteenoja, O., Reátegui, Y.R., Räsänen, M., Torres, D.D.C., Oinonen, M., Page, S., 2012. The large Amazonian peatland carbon sink in the subsiding Pastaza-Marañón foreland basin, Peru. Glob. Chang. Biol. 18, 164-178. doi:10.1111/j.13652486.2011.02504.x

Lemmens, R.H.M.J., Soerianegara, I., Wong, W.C., 1995. Plant Resources of SouthEast Asia No. 5(2). Timber trees: Minor commercial timbers. Prosea Foundation, Bogor, Indonesia

Lemmens, R.H.M.J., Bunyapraphatsara, N. 2003. Plant Resources of South-East Asia 12(3) Medicinal and Poisonous Plants. Prosea Foundation, Bogor, Indonesia.

Limpens, J., Berendse, F., Blodau, C., Canadell, J.G., Freeman, C., Holden, J., Roulet, N., Rydin, H., Schaepman-Strub, G., 2008. Peatlands and the carbon cycle: from local processes to global implications - a synthesis. Biogeosciences 5, 1475-1491. doi:10.5194/bg-5-1475-2008

Locher-Scholten, E., 2003. Sumatran Sultanate and Colonial State: Jambi and the Rise of Dutch Imperialism, 1830-1907. Cornell University Press, Ithaca and New York.

Ludang, Y., Jaya, A., Inoue, T., 2007. Microclimate Condition of the Developed Peatland in Central Kalimantan. Journal of Applied Sciences 7(18), 2604-2609.

Lynch, J.A., Hollis, J.L., Hu, F.S., 2004. Climatic and landscape controls of the boreal forest fire regime: Holocene records from Alaska J. Ecol. 92, 477. doi:10.1111/j.0022-0477.2004.00879.x

Manner, H.I., Elevitch, C.R., 2006. Gnetum gnemon (gnemon), ver. 1.1. In: Elevitch, C.R. (Editor) Species profiles for Pacific Island Agroforestry. Permanent Agriculture Resources (PAR), Holualoa, Hawai'i. http://www.traditionaltree.org

Mani, M.S., Giddings, L.E., 1980. Ecology of Highlands. In: Dumont, H.J (Editor). Monographiae Biologicae. Junk bv Publication, The Hague, Netherlands.

Masuda, S., Tani, N., Ueno, S., Lee, S.L, Muhammad, N., Kondo, T., Numata, S., Tsumura, Y., 2013. Non-Density Dependent Pollen Dispersal of Shorea maxwelliana (Dipterocarpaceae) Revealed by a Bayesian Mating Model Based on Paternity Analysis in Two Synchronized Flowering Seasons. PLoS ONE 8(12), e82039. doi:10.1371/journal.pone.0082039

Melati, D.N., Jaya, I.N.S., Pérez-Cruzado, C., Zuhdi, M., Fehrmann, L., Magdon, P., Kleinn, C., 2015. Spatio-temporal analysis on land transformation in a forested tropical landscape in Jambi Province, Sumatra. In conference presentation of European Geosciences Union General Assembly 17 April 2015. Vienna, Austria.

Meyers, P.A., 1994. Preservation of elemental and isotopic source identification of sedimentary organic matter. Chem. Geol. 114, 289-302. doi:10.1016/00092541(94)90059-0 
Miettinen, J., Hooijer, A., Tollenaar, D., Page, S.E., Malins, C., Vernimmen, R., Shi, C., Liew, S.C., 2012. Extent of industrial plantations on Southeast Asian peatlands in 2010 with analysis of historical expansion and future projections. Glob. Chang. Biol. and Bioenergy 4:908-18

Morley, R.J. 1981. Development and vegetation dynamics of a lowland ombrogenous peat swamp in Kalimantan Tengah, Indonesia. J. Biogeogr. 8, 383-404.

Muller, J., 1963. Palynological study of Holocene peat in Sarawak. Proceedings of the Symposium of Ecological Restoration in the Humid Tropics, pp.147-156.

Neuzil, S.G., 1997. Onset and Rate of Peat and Carbon Accumulation in Four Domed Ombrogenous Peat Deposits, Indonesia. Proceedings of the International Symposium of Biodiversity, Environmental Importance and Sustainability of Tropical Peat and Peatlands, pp. 55-72.

Niedermeyer, E.M., Sessions, A.L., Feakins, S.J., Mohtadi, M., 2014. Hydroclimate of the western Indo-Pacific Warm Pool during the past 24,000 years. Proc. Natl. Acad. Sci. U.S.A. 111, 9402-9406. doi:10.1073/pnas.1323585111

Nurjanah, S., Octavia, D., Kusumadewi, F., 2013. Identifikasi lokasi penanaman kembali ramin (Gonystilus bancanus Kurz) di hutan rawa gambut Sumatra dan Kalimantan. Pusat Penelitian dan Pengembangan Konservasi dan Rehabilitasi with International Tropical Timber Organization (ITTO)-CITES Phase 2 Project, Bogor, Indonesia.

Padmanaba, M., Sheil, D., 2014. Spread of the invasive alien species Piper aduncum via logging roads in Borneo. Trop. Conserv. Sci. 7, 35-44.

Page, S.E., Rieley, J.O., Shotyk, W., Weiss, D., 1999. Interdependence of peat and vegetation in a tropical peat swamp forest. Philos. Trans. R. Soc. Lond. B 354, 1885-1897. doi:10.1098/rstb.1999.0529

Page, S.E., Siegert, F., Rieley, J.O., Boehm, H.V., Jaya, A., Limin, S., 2002. The amount of carbon released from peat and forest fires in Indonesia during 1997. Nature 420, 61-65. doi:10.1038/nature01131

Page, S., Wust, R., Weiss, D., Rieley, J.O., Shotyk, W., Limin, S.H., 2004. A record of Late Pleistocene and Holocene carbon accumulation and climate change from an equatorial peat bog (Kalimantan, Indonesia): implication of past, present and future carbon dynamics. J. Quaternary Sci. 19, 625-635. doi:10.1002/jqs.884

Page, S., Wust, R., Banks, C., 2010. Past and present carbon accumulation and loss in Southeast Asian peatlands. Pages news 18, 25-26.

Page, S.E., Rieley, J.O., Banks, C.J., 2011. Global and regional importance of the tropical peatland carbon pool. Glob. Chang. Biol. 17, 798-818. doi:10.1111/j.13652486.2010.02279.x

Page, S.E., Baird, A.J., 2016. Peatlands and global change: Response and Resilience. Annu. Rev. Environ. Resour. 41, 35-57. doi: 10.1146/annurev-environ-110615085520

Partin, J.W., Cobb, K.M., Adkins, J.F., Clark, B., Fernandez, D.P., 2007. Millennialscale trends in west Pacific warm pool hydrology since the Last Glacial Maximum. Nature 449, 452-455. doi:10.1038/nature06164 
Panujen, H., 1996. Mires as late Quaternary accumulation basins in Rwanda and Burundi, Central Africa. Geological Survey of Finland. Bulletin 384. doi:10.1038/362583d0

Posa, M.R.C., Wijedasa, L.S., Corlett, R.T., 2011. Biodiversity and Conservation of Tropical Peat Swamp Forests. BioScience 61, 49-57. doi:10.1525/bio.2011.61.1.10

R Core Team, 2014. R: A language and environment for statistical computing. R Foundation for Statistical Computing, Vienna, Austria. http://www.R-project.org/.

Radke, P., Radke, A., 1993. Growing Australian Tropical Plants. Frith \& Frith Books. Queensland, Australia.

Rhodes, A.N., 1998. A method for the preparation and quantification of microscopic charcoal from terrestrial and lacustrine sediment cores. The Holocene 8, 113-117. doi:10.1191/095968398671104653

Rodrigues, J., Faix, O., Pereira, H., 1998. Determination of Lignin Content of Eucalyptus glotylus Wood Using FTIR Spectroscopy. Holzforschung 52, 46-50.

Rohling, E. J., Grant, K., Hemleben, C., Siddall, M., Hoogakker, B.A.A., Bolshaw, M., Kucera, M., 2008. High rates of sea-level rise during the last interglacial period. Nat. Geosci. 1, 38-42. doi:10.1038/ngeo.2007.28.

Saji, N.H., Goswami, B.N., Vinayachandran, P.N., Yamagata, T., 1999. A dipole mode in the tropical Indian Ocean. Nature 401, 360-3. doi:10.1038/43854

Sathiamurthy, E., Voris, K.H., 2006. Maps of Holocene Sea Level Transgression and Submerged Lakes on the Sunda Shelf. The Natural History Journal of Chulalongkorn University 2, 1-44.

Saunders, M.J., Kansiime, F., Jones, M.B., 2013. Reviewing the carbon cycle dynamics and carbon sequestration potential of Cyperus papyrus L. wetlands in tropical Africa. Wetl. Ecol. Manag. 22, 143-155. doi:10.1007/s11273-013-9314-6

Schumann, M., Joosten, H., 2008. Global Peatland Restoration Manual. Institute of Botany and Landscape Ecology, Griefswald University, Germany.

Sinsabaugh, R.L., 2010. Phenol oxidase, peroxidase and organic matter dynamics of soil. Soil Biol. Biochem. 42, 391-404. doi:10.1016/j.soilbio.2009.10.014

Soerianegara, I., Lemmens, R.H.M.J., 1994. Plant Resources of South-East Asia No. 5(1). Timber trees: Major commercial timbers. Prosea Foundation, Bogor, Indonesia.

Sosef, M.S.M, Hong, L.T., Prawirohatmodjo, S.,1998. Plant Resources of South-East Asia No. 5(3). Timber trees: Lesser-known timbers. Prosea Foundation, Bogor, Indonesia.

Stevenson, J., Haberle, S., 2005. Macro Charcoal Analysis : A modified technique used by the Department of Archaeology and Natural History. Australian National University, Canberra.

Supiandi, S., Furukawa, H., 1986. Problem Soils in Southeast Asia A Study of Floral Composition of Peat Soil in the Lower Batang Hari River Basin of Jambi, Sumatra. J. Southeast Asian Stud. 24, 113-132.

Supiandi, S., 1988. Studies on Peat in the Coastal Plains of Sumatra and Borneo. J. 
Southeast Asian Stud. 27, 461-485.

Tata, H.L., van Noordwidjk, M., Jasnari, Widayati, A., 2016. Domestication of Dyera polyphylla (Miq.) Steenis in peatland agroforestry systems in Jambi, Indonesia. Agrofor. Syst. 90, 617-630. doi:10.1007/s10457-015-9837-3

Tjoa-Bonatz, M.L., Neidel, J.D., Widiatmoko, A., 2009. Early Architectural Images from Muara Jambi on Sumatra, Indonesia. Asian Perspect. 48, 32-55. doi:10.1353/asi.0.0009

Tolonen, K., Turunen, J., 1996. Accumulation rates of carbon in mires in Finland and implications for climate change. Holocene 6(2), 171-178.

van Dam, A., Kipkemboi, J., Zaal, F., Okeyo-Owuor, J.B., 2011. The ecology of livelihoods in East African papyrus wetlands (ECOLIVE). Rev. Environ. Sci. Biotechnol. doi: 10.1007/s11157-011-9255-6

van Geest,G.J., Wolters, H., Roozen, F.C.J.M., Coops, H., Roijackers, R.M.M., Buijse, A.D., Scheffer, M., 2005. Water-level fluctuations affect macrophyte richness in floodplain lakes. Hydrobiologia 539, 239-248. doi: 10.1007/s10750-004-4879-y

Veloo, R., Paramananthan, S., Van Ranst, E., 2014. Classification of tropical lowland peats revisited: The case of Sarawak. Catena 118, 179-185. doi:10.1016/j.catena.2014.01.004

Whalen, J.K., Sampedro, L., 2010. Soil ecology and management. Cambridge University Press. Cambridge, United Kingdom.

Whittle, A., Gallego-Salla, A., 2016. Vulnerability of the peatland carbon sink to sealevel rise. Sci. Rep. 6, 2875. doi: 10.1038/srep28758

Witrianto, 2014. Potensi sejarah dan purbakala DAS Batanghari. Analisis Sejarah 5, 6879.

Wösten, J.H.M., Clymans, E., Page, S.E., Rieley, J.O., Limin, S.H., 2008. Peat-water interrelationships in a tropical peatland ecosystem in South-east Asia. Catena 73, 212-224.

Wüst, R.A.J., Bustin, R.M., Lavkulich, L.M., 2003. New classification systems for tropical organic-rich deposits based on studies of the Tasek Bera Basin, Malaysia. Catena 53, 133-163. doi:10.1016/S0341-8162(03)00022-5

Wüst, R.A.J., Rieley, J., Page, S., van der Kaars, S., Wie-Ming, W., Jacobsen, G., Smith, A., 2007. Peatland evolution in SE Asia during the last 35,000 cal years: Implication for evaluating their carbon storage potential. Proceedings of the International Symposium and Workshop on Tropical Peatland (27 -29 August, Yogyakarta), pp. 25-40.

Wüst, R. J., G. E. Jacobsen, H. van der Gaast, and A. M. Smith (2008), Comparison of radiocarbon ages from different organic fractions in tropical peat cores: insights from Kalimantan, Indonesia. Radiocarbon 50, 359-372.

Yang, W., Shimanouchi , T., Iwamura, M., Takahashi, Y., Mano, R., Takashima, K., Tanifuji, T., Kimura, Y., 2015. Elevating the fuel properties of Humulus lupulus, Plumeria alba and Calophyllum inophyllum L. through wet torrefaction. Fuel 146, 88-94. http://dx.doi.org/10.1016/j.fuel.2015.01.005 
Yu, Z., Loisel, J., Brosseau, D.P., Beilman, D.W., Hunt, S.J., 2010. Global peatland dynamics since the Last Glacial Maximum. Geophys. Res. Lett. 37, L13402, doi:10.1029/2010GL043584

Yu, Z., Beilman, D.W., Frolking, S., MacDonald, G.M., Roulet, N.T., Camill, P., Charman, D.J., 2011. Peatlands and Their Role in the Global Carbon Cycle. EOS 92, 97-108. doi:10.1029/2011EO120001

Yule CM, Lim, Y.Y., Lim, T.Y., 2016. Degradation of Tropical Malaysian Peatlands Decreases Levels of Phenolics in Soil and in Leaves of Macaranga pruinosa. Front. Earth Sci. 4, 45. doi: 10.3389/feart.2016.00045

Yulianto, E., Hirakawa, K., 2006. Vegetation and environmental change in the early Middle holocene at a tropical peat swamp forest, Central Kalimantan, Indonesia. Tropics 15, 65-73.

Yulianto, E., Rahardjo, A.T., Noeradi, D., Siregar, D.A., Hirakawa, K., 2005. A Holocene pollen record of vegetation and coastal environmental changes in the coastal swamp forest at Batulicin, South Kalimantan, Indonesia. J. Asian Earth Sci., 25(1), 1-8. doi:10.1016/j.jseaes.2004.01.005 


\section{Supplementary 1}

Detail parameter applied to macro-charcoal data in CharAnalysis

The raw charcoal data are interpolated into 32 years (the median temporal resolution) and converted into charcoal accumulation rates as particle $\mathrm{cm}^{-2} \mathrm{yr}^{-1}$. The charcoal accumulation rates are then separated into a background and peak components using a 1,000-yr window locally weighted regression robust to outliers. The peak component $\left(\mathrm{C}_{\text {peak }}\right)$ is defined as residual after removing the noise (resulting from distant fires, redeposition, or analytical error) using a locally defined Gaussian mixture model (Gavin et al., 2006; Higuera et al., 2008). Peaks exceeding the $99^{\text {th }}$ percentile threshold of the noise distribution are identified as fire peaks. Identified peaks are subjected to a "Poisson minimum count" to evaluate whether the identified-peak charcoal count has more than $5 \%$ chance to emerge from the same Poisson-distributed population as the counts of the previous five samples, and thus reduced the counting variance bias. Fire frequencies over time are calculated based on the frequency of fire peaks per 1,000 years. Peak magnitude as a measure of total charcoal deposition per event (Higuera et al., 2009), is used to reflect fuel consumption per fire and/or fire size. A total of 23 fire peaks are detected along the core. The local signal-to-noise index (SNI) represents the standard deviation units which separate the charcoal peak identified to the mean of the modelled noise distribution of the peak charcoal series (Kelly et al., 2011). SNI values for SB-B macro-charcoal data are fluctuating around 3, indicating a good separation of noise and signal (peak) populations (Kelly et al., 2011). The mean fire return interval (FRI) is $598 \mathrm{yr}(425-784 \mathrm{yr})$.

\section{Reference}

Gavin, D.G., Feng, S.H., Lertzman, K., Corbett, P., 2006. Weak climatic control of stand-scale fire history during the late Holocene. Ecology 87, 1722-1732. doi:10.1890/0012-9658(2006)87[1722:WCCOSF]2.0.CO;2

Higuera, P.E., Brubaker, L.B., Anderson, P.M., Brown, T.A., Kennedy, A.T., Hu, F.S., 2008. Frequent fires in ancient shrub tundra: Implications of paleorecords for arctic environmental change. PLoS ONE 3, 1-7. doi:10.1371/journal.pone.0001744

Higuera, P.E., Brubaker, L.B., Anderson, P.M., Hu, F.S., Brown, T.A., 2009. Vegetation mediated the impacts of postglacial climatic change on fire regimes in the south-central Brooks Range, Alaska. Ecol. Monogr. 79, 201-219. doi:10.1890/07-2019.1

Kelly, R.F., Higuera, P.E., Barrett, C.M., Hu, F.S., 2011. A signal-to-noise index to quantify the potential for peak detection in sediment-charcoal records. Quat. Res.75, 11-17. doi:10.1016/j.yqres.2010.07.011 


\section{Supplementary 2}

Cluster analysis result of the pollen and spore data.

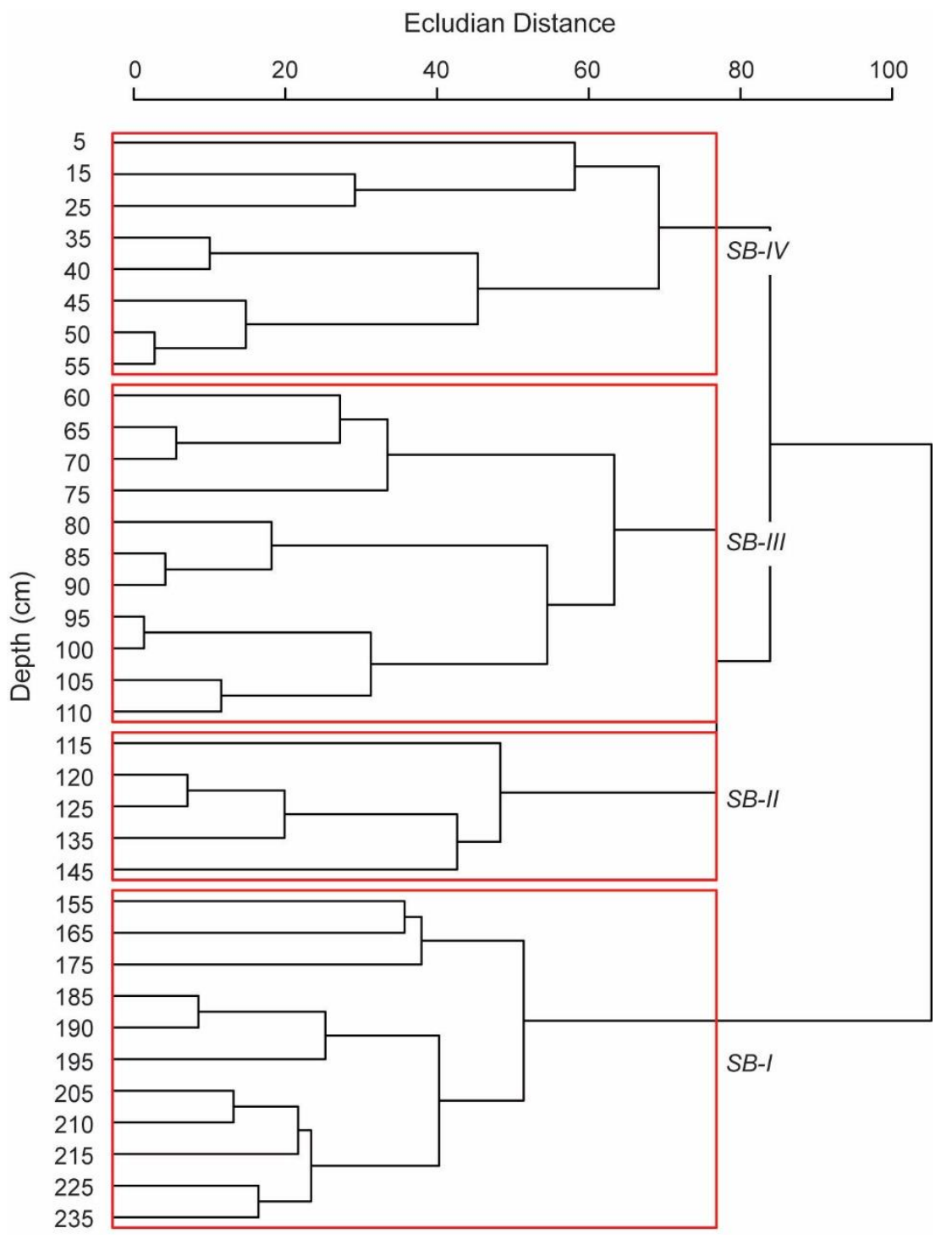




\section{Supplementary 3}

Complete list of plant taxa identified from pollen and spore analyses

Peat-swamp forest

\section{Plant family}

Anisophylleaceae

Annonaceae

Arecaceae

Bignoniaceae

Burseraceae

Chrysobalanaceae

Clusiaceae

Euphorbiaceae

Dipterocarpaceae
Pollen taxon

Combretocarpus

Radermachera

Canarium

Burseraeae type

Parastemon

Calophyllum

Garcinia

Blumeodendron

Euphorbiaceae type

Neoscortechinia

Shorea

\section{Plant family}

Ebenaceae

Gnetaceae

Lauraceae

Loranthaceae

Malvaceae

Moraceae-Urticaceae

Pandanaceae

Sapindaceae

Sapotaceae

Stemonuraceae

\section{Mixed-riparian forest}

\section{Plant family}

Anacardiaceae

Aquifoliaceae

Cannabaceae

Cornaceae

Euphorbiaceae

Dipterocarpaceae

type

Myrtaceae

Olacaceae

Pandanaceae

\section{Ubiquitus}

Plant family

Melastomataceae

Menispermaceae

Moraceae-Urticaceae

\section{Pollen taxon}

Campnosperma

Ilex

Celtis

Macaranga

Dipterocarpaceae

Anacolosa

Pandanus
Plant family

Phyllanthaceae

Polygalaceae

Rubiaceae

Sapindaceae

Verbenaceae
Pollen taxon

Diospyros

Gnetum

Bombacoideae

Durio

Ficus

Freycinetia

Sapindaceae type

Palaquium

Sapotaceae type

Stemonuraceae type

Stemonurus

Pollen taxon

Antidesma

Canthium

Nauclea

Randia

Rubiaceae type

Timonius

Pometia

\section{Pollen taxon}

Moraceae-Urticaceae type

\section{Open vegetation}

\section{Plant family}

Convolvulaceae

Malvaceae

Onagraceae

$\begin{array}{ll}\text { Pollen taxon } & \text { Plant family } \\ & \text { Piperaceae } \\ \text { Grewioideae } & \text { Poaceae } \\ & \text { Primulaceae }\end{array}$

Pollen taxon

Piper

Ardisia 
Chapter 2 - Environmental and carbon dynamics of coastal peatland
Mangrove

Plant family

Lythraceae

Rhizophoraceae

\section{Spores}

Plant family

Blechnaceae

Davalliaceae

Lycopodiaceae

Monolete
Pollen taxon

Sonneratia

Spore taxon

Stenochlaena

Davallia

Plant family

Nephrolepidaceae

Polypodiaceae

Pteridaceae

Trilete
Spore taxon

Nephrolepis 


\section{Chapter 3}

\section{Resilience of a peatland in Central Sumatra, Indonesia to past anthropogenic disturbance: improving conservation and restoration designs using palaeoecology}

Kartika Anggi Hapsari ${ }^{1 *}$, Siria Biagioni ${ }^{1}$, Tim C. Jennerjahn ${ }^{2}$, Peter Reimer ${ }^{3}$, Asmadi $\mathrm{Saad}^{4}$, Supiandi Sabiham ${ }^{5}$, Hermann Behling ${ }^{1}$

${ }^{1}$ Department of Palynology and Climate Dynamics - Albrecht-von-Haller Institute for Plant Sciences, Georg-August-University of Goettingen, Germany

2 Department of Biogeochemistry and Geology, Leibniz Centre for Tropical Marine Research (ZMT) Bremen, Germany

${ }^{3}$ Department of Biological Science, Goshen College, Indiana, USA

${ }^{4}$ Department of Soil Science, University of Jambi, Indonesia

${ }^{5}$ Department of Soil Science and Land Resource, Bogor Agriculture University (IPB), Indonesia

Journal of Ecology (2018) 106(6): 2743-2490

doi: $10.1111 / 1365-2745.13000$ 


\section{$\underline{\text { Abstract }}$}

1. Tropical peatlands, which provide important functions such as biodiversity provisioning and carbon (C) storage, are currently threatened by land-use conversions. Thus, conservation and restoration efforts are needed to maintain their functions. Conservation concepts aiming to separate human from ecosystems are no longer conceivable. Therefore, understanding peatland resilience to human disturbance, that is the ability of peatland ecosystems to maintain their structure and function despite perturbations and to return to their pre-disturbance states, can assist with integrating human needs into conservation strategies and improving restoration effectiveness.

2. Understanding ecosystem resilience is often impeded by a lack of long-term data, which can be obtained from palaeoecological studies. Located close to the archaeological remains of the Malayu Empire, the Sungai Buluh peatland in Sumatra, Indonesia provides an opportunity to study the resilience of a tropical peatland to past human disturbance. We subjected a $250 \mathrm{~cm}$-long peat core to palynological, charcoal and $\mathrm{C}$ content analyses to delineate the anthropogenic impact on the peatland and the ecosystem's response.

3. The results revealed that extensive human activities in Sungai Buluh such as logging, grazing/cut-and-carry, and wild-harvesting started soon after humans occupied the vicinity of the peatland ca. 1000 cal yr BP. Even without fire use and cultivation, these activities were able to alter vegetation composition and decrease the peatland's C sequestration capacity.

4. Following site abandonment after the demise of the Malayu Empire at ca. 600 cal yr $\mathrm{BP}$, the palaeoecological record suggests that the Sungai Buluh peatland recovered 
in terms of both floristic composition and $\mathrm{C}$ sink function, with the latter recovering faster (ca. 60 years) than the former (ca. 170 years).

5. Synthesis: The palaeoecological record from Sungai Buluh provides the first evidence of tropical peatland recovery following human disturbance, which can help improve present peatland conservation/restoration strategies. The design of peatland wise-use strategies can mimic the 'resilience-friendly' human activities identified in this study. Consideration should also be given to selecting rapidly regenerating taxa for cost-and-effort-efficient restoration strategies. Additionally, the 170-year recovery time of the Sungai Buluh peatland suggests that the 60 -year timeframe currently allocated in most tropical peatland restoration projects may be insufficient.

Keywords: palaeoecology and land-use history, ecosystem function and services, human activities, natural recovery, peat carbon sink, sustainable use, restoration design, local policy 


\section{$\underline{\text { Second language abstract (Bahasa Indonesia) }}$}

1. Keberadaan lahan gambut tropis yang memiliki peran penting dalam menjaga keanekaragaman hayati dan penyimpanan karbon saat ini semakin terancam karena adanya kegiatan alih fungsi lahan. Upaya konservasi dan restorasi sangat diperlukan untuk menjaga keberlangsungan fungsi ekologis lahan gambut tersebut. Namun, konsep konservasi yang bertujuan memisahkan aktivitas manusia dari lingkungan akan kurang sesuai jika diterapkan di era dominasi manusia seperti sekarang. Oleh karena itu, pemahaman daya lenting (resilience) ekosistem lahan gambut terhadap gangguan aktivitas manusia sangat penting untuk mengintegrasikan kebutuhan masyarakat lokal ke dalam strategi konservasi serta meningkatan efektivitas upaya restorasi lahan gambut.

2. Namun, pemahaman terhadap daya lenting ekosistem pada umumnya terhambat oleh ketidaktersediaan informasi jangka panjang yang semestinya dapat diperoleh melalui studi palaeoekologi (ekologi di masa lampau). Lahan gambut Sungai Buluh di Sumatra merupakan area ideal untuk mempelajari daya lenting ekosistem lahan gambut tropis terhadap aktivitas manusia di masa lampau karena berlokasi dekat dengan situs arkeologi Muara Jambi, peninggalan Kerajaan Melayu Jambi. Kami manggunakan sampel bor sepanjang $250 \mathrm{~cm}$ yang diperoleh dari lahan gambut Sungai Buluh untuk analisis kandungan polen, partikel arang (charcoal) dan karbon, guna menggambarkan dampak antropogenik pada lahan gambut dan respon ekosistemnya.

3. Hasil studi menunjukkan bahwa aktivitas manusia di lahan gambut Sungai Buluh antara lain penebangan kayu, penggembalaan ternak/mengarit, serta panen hasil 
hutan, sudah dimulai sejak masyarakat Kerjaan Melayu Jambi menempati daerah sekitar lokasi tersebut pada tahun 1000 SM. Aktivitas tersebut mampu mengubah komposisi tutupan vegetasi dan mengurangi daya serap karbon lahan gambut, meskipun tanpa melakukan pembakaran lahan dan agrikultur.

4. Setelah Kerajaan Melayu runtuh dan situs Muara Jambi ditinggalkan pada tahun 600 SM, studi palaeoekologi menunjukkan bahwa komposisi flora serta daya serap karbon lahan gambut Sungai Buluh kembali pulih. Pemulihan daya serap karbon lahan gambut Sungai Buluh memerlukan waktu lebih-kurang 60 tahun, lebih cepat dari waktu yang dibutuhkan untuk pemulihan komposisi flora (lebih-kurang 170 tahun).

5. Sintesis: Studi palaeoekologi di Sungai Buluh menghadirkan bukti pertama dari pemulihan lahan gambut tropis terhadap aktivitas manusia, dan bukti tersebut penting untuk meningkatkan strategi konservasi serta restorasi lahan gambut. Rancangan pemanfaatan lahan gambut secara berkelanjutan dapat meniru/mengikuti aktivitas manusia di masa lampau yang tidak mengganggu daya lenting ekosistem. Pertimbangan dalam hal pemilihan taksa yang cepat beregenerasi juga harus diberikan demi strategi restorasi yang lebih efisien dalam hal biaya dan usaha. Selanjutnya, alokasi waktu selama 60 tahun untuk restorasi lahan gambut (sebagian besar program restorasi lahan gambut di Indonesia saat ini) sangat tidak mencukupi/memadai jika dibandingkan dengan kisaran waktu 170 tahun yang dibutuhkan lahan gambut Sungai Buluh untuk pulih dari aktivitas manusia di masa lampau. 


\subsection{Introduction}

Tropical peatlands are important for water regulation (Rieley, 2007) and harbour a rich biodiversity possessing specialised adaptations to waterlogged, acidic, and nutrient-poor conditions (Yule, 2010; Posa et al., 2011). These ecosystems also play a significant role in the global carbon (C) cycle, as they store $18 \%$ of the total global peat $\mathrm{C}$ pool (Page et al., 2011; Dargie et al., 2017). Around $65 \%$ of the global tropical peat C pools are located in Indonesia and Malaysia, primarily distributed along the coast of Sumatra and Borneo, Indonesia (Page et al., 2011; Dargie et al., 2017). Due to rapid population increase and economic growth in Indonesia over the past few decades, pressure on these peatlands has escalated quickly (Brady, 1997). Only from 1990-2010, 4.5 Mha of peatland cover in Indonesia has been converted to plantation and urban areas (Miettinen et al., 2012). Such conversions jeopardise the survival of specialised taxa, disturb the important hydrological functions of these ecosystems and increase the rate of $\mathrm{C}$ release (Page et al., 2009; Petrenko et al., 2016; Wijedasa et al., 2017). Additionally, these conversions reduce the significant economic value of peatlands as a source of food and building materials or as a $\mathrm{C}$ sink, a service that is worth up to $\$ 22$ per tonne $\mathrm{CO}_{2}$ sequestered (van Beukering et al., 2008), by virtue of the destruction of the peat-swamp forest which provide these ecosystem services. Thus, strategies to maintain and sustain the ecosystem functions of these peatlands through conservation and restoration are required.

Conservation is an effort to preserve the existing ecosystems and prevent them from further degradation (Gerber, 2010), whereas restoration actively reverses the degradation in order to strengthen the ecosystems resilience (Lake, 2013). In Indonesia, several conservation and restoration efforts on peatlands are already underway. 
However, expectations are low for these efforts, primarily due to the fragmented knowledge of the target ecosystems and the neglect of the socioeconomic and cultural aspects (Giesen \& van der Meer, 2009; Page et al., 2009; van Eijk et al., 2009; Graham et al., 2017).

In order to effectively sustain the ecosystem properties (attributes that characterise the ecosystems e.g. soil properties, biodiversity, primary productivity; Bastian et al., 2012) and services (directly or indirectly beneficial to human well-being e.g. food provisioning, carbon sequestration, natural hazard protection; Bastian et al., 2012) and/or to reverse the degradation of an ecosystem, it is essential to first understand the impact of past and present disturbances on the ecosystem while also assessing the ecosystem's resilience (Chapin III et al., 2009).

The term "resilience" has been variously defined in the ecological literature (e.g. Gunderson, 2000; Carpenter et al., 2001). For this study, resilience is defined as the ability of an ecosystem subject to disturbances to maintain its structure and function (Holling, 1973), and return to its pre-disturbance state. Resilience comprises both resistance (the capability to absorb perturbations and resist shifts of its structure) and recovery (the capability to return to its previous condition after a perturbation; Holling, 1996). Ecosystem resilience can be altered by adding/removing stressors or drivers of change (Côté \& Darling, 2010).

Human impact is one factor that can reduce ecosystem resilience, resulting in a failure of the affected ecosystem to recover (GBRMPA, 2009). For these reasons, old conservation concepts tried to separate humans from the ecosystem (Miller \& Hobbs, 2002; Chapin III et al., 2009; Sörlin \& Warde, 2009; Ramutsindela, 2014). However, in our human-dominated world, it is almost impossible to separate humans from ecosystem 
processes (Laurila-Pant et al., 2015). Consequently, humans need to be considered as part of the ecosystem and included in conservation strategies (Miller \& Hobbs, 2002; Gorenflo \& Brandon, 2006; Laurila-Pant et al., 2015). Understanding ecosystem resilience in response to human activity provides a valuable basis for the integration of humans into the design of ecosystem conservation and restoration strategies.

In general, ecosystem resistance can be assessed when disturbance severity increases, whereas ecosystem recovery, which is often a slow process that might take decades or even centuries, can only be observed once the disturbance is alleviated (Dobson et al., 1997; Lake, 2013). As a result, understanding ecosystem resilience, particularly in response to ongoing human-induced disturbances, requires long periods of observation and/or extensive time-series information (Leslie \& McCabe, 2013; Mumby et al., 2014). Thus, understanding resilience is often hindered by a lack of long-term data (Martin et al., 2013; Cole et al., 2015), which can be obtained from palaeoecological studies (Bhagwat et al., 2011; Birks, 2012; Page \& Baird, 2016). This is particularly true for tropical peatlands, where very little is known about the effects of past anthropogenic disturbances (Hope et al., 2005; Biagioni et al., 2015; Dommain et al., 2015). In SE Asia, evidence of human activities in peatlands is only reported in a limited number of studies (Anshari et al., 2001; Yulianto et al., 2005; Hunt \& Premathilake, 2012; Cole et al., 2015).

Aiming to assess the resilience of a tropical peatland to human disturbance, we conducted a study on a natural archive from Sungai Buluh peatland in Sumatra, Indonesia. Due to its vicinity to the Muara Jambi temple complex, the archaeological remains of the former Malayu Empire, Sungai Buluh peatland provides a unique opportunity to understand the impact of anthropogenic disturbances on peatland 
ecosystems. Four main questions arise: (1) What anthropogenic activities were conducted by the Malayu Empire in Sungai Buluh? (2) How did those activities impact the peatland? (3) Did the peatland recover from those disturbances? (4) If so, how long did it take for the peatland to recover?

The outcomes of this study are intended to help improve present-day peatland management, conservation and restoration practice such as: (1) Designing peatland conservation and sustainable use; (2) Enhancing the effectiveness and efficiency of peatland restoration in terms of cost and effort; and (3) Improving peatland restoration frameworks and local government policy.

\subsection{Study site}

\subsubsection{Environmental and archaeological setting}

The Sungai Buluh peatland is located in Central Sumatra, approximately $19 \mathrm{~km}$ from the coastline and $30 \mathrm{~km}$ north-east of the city of Jambi (Fig. 3.1). It covers an area of 18,000 ha. The study area is covered by secondary peat-swamp forest resulting from regrowth following selective cutting during the 1960s and -70s based on the selectivelogging concession granted by then President of the Republic of Indonesia (Nurjanah et al., 2013). Sungai Buluh peatland is surrounded by an area converted to agricultural fields and plantations, for example, pulp wood (Acacia spp.) and oil palm (Elaeis guineensis; Melati et al., 2015). The peat-swamp forest canopy was reduced due to the El Niño related fires in 1997 (Tata et al., 2016). The area was planted with Shorea pauciflora and Dyera polyphylla trees in 2003 following the instructions from the Department of Forestry of Jambi Province (Nurjanah et al., 2013). 
The elevation of Sungai Buluh ranges from 9 to $25 \mathrm{~m}$ above sea level (asl) with a tropical humid climate. The average yearly temperature is $27^{\circ} \mathrm{C}$ (WorldClim - Global Climate Data, http://www.worldclim.org/), with mean annual rainfall amounts of 2400 mm (Aldrian \& Susanto, 2003). Precipitation patterns of the area are influenced by seasonal variations of the Asian-Australian monsoon and the Intertropical Convergence Zone (ITZC; Saji et al., 1999). Meanwhile, the inter-annual rainfall variation is affected by the El Niño-Southern Oscillation (ENSO; Aldrian \& Susanto, 2003) and the Indian Ocean Dipole (IOD; Saji et al., 1999).

Around $28 \mathrm{~km}$ south of Sungai Buluh peatland, the ancient Muara Jambi temple complex is found on the banks of the Batanghari River (Fig. 3.1). It is reported to be a remnant of the Malayu Empire and covers about 1200 ha. The Malayu Empire was one of the largest empires in Indonesian history and renowned as the largest pepper centre in Sumatra (Witrianto, 2014). This empire is reported to have been established prior to the $7^{\text {th }}$ century and is suspected to be part of the Srivijaya Kingdom (McKinnon, 1985; Wolters, 1986; Rahman, 1993). An inscription found in Karang Brahi (Merangin, Jambi) suggests that the Malayu Empire was previously based in the upper Batanghari (McKinnon, 1985; Wolters, 1986; Andaya, 2001).

Muara Jambi, the capital of the Empire, was built later between the $9^{\text {th }}$ and $10^{\text {th }}$ century (McKinnon, 1985; Tjoa-Bonatz et al., 2009). This temple complex served as an administrative and ceremonial centre, a settlement, and an important international trading centre (McKinnon, 1985; Tjoa-Bonatz et al., 2009). Muara Jambi was surrounded by some small settlements, with the five largest complexes ranging from 1140 ha in size (Fig. 3.1; Alam, 2014). In the $14^{\text {th }}$ century, the Empire was conquered by a Javanese kingdom, the Majapahit. The Empire then became a vassal of Majapahit and 
was ruled by King Adityawarman (Witrianto, 2014; Kozok \& van Reijn, 2010). In 1347

AD, King Adiyawarman declared his independence from Majapahit and moved the Empire to Saruaso, Minangkabau-West Sumatra (Witrianto, 2014; Kozok \& van Reijn, 2010). The settlements of the Muara Jambi complex and on the lower Batanghari were later destroyed completely by the Javanese in 1377 AD (McKinnon, 1985; Wolters, 1986).

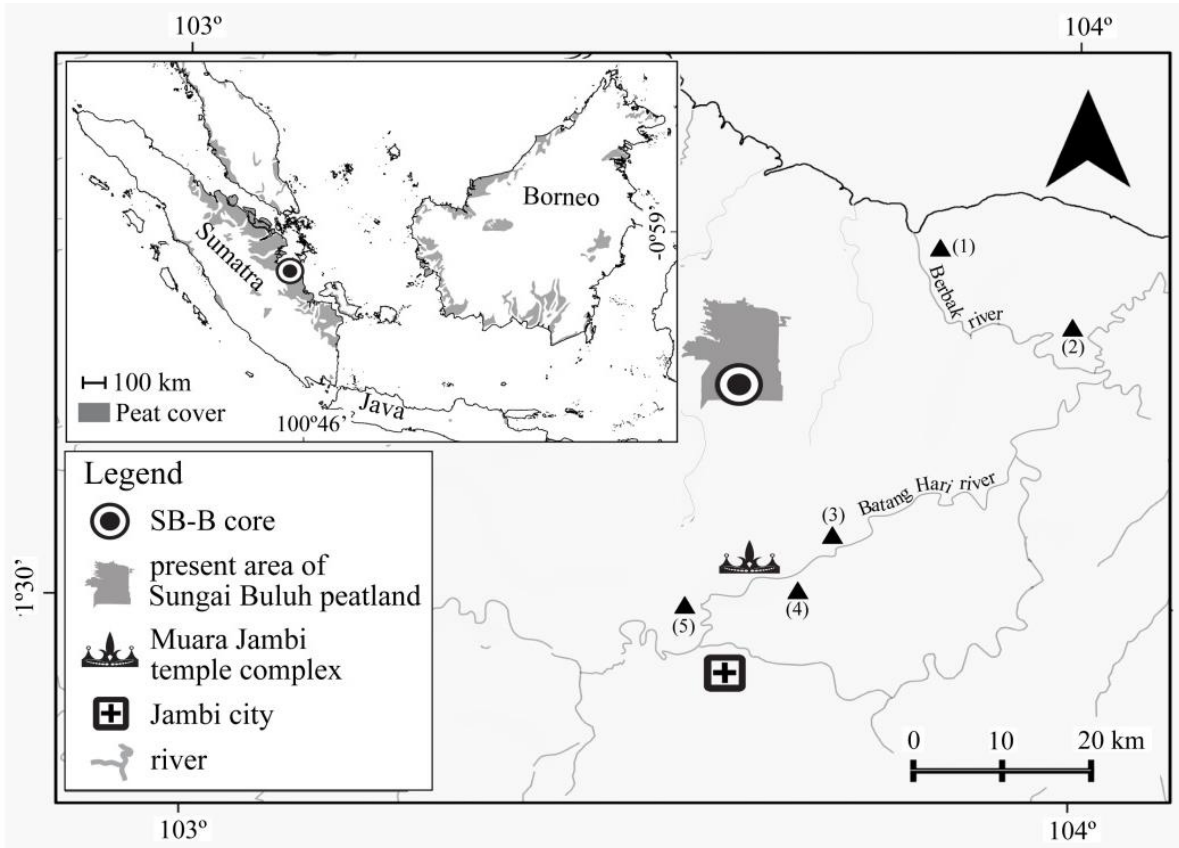

Fig. 3.1. Map of the study site. Black triangles represent the five largest settlement complex $(1-140$ ha) that existed around the period of the Malayu Empire: (1) Lambur, (2) Kota Kandis (3) Jebus (4) Suak Kandis (5) Candi Teluk (McKinnon, 1985; Alam, 2014).

\subsubsection{Palaeoecological setting}

The palaeoecological setting of Sungai Buluh peatland is described in detail by Hapsari et al. (2017), in which, the peat accumulation rate (PAR; annual deposition rate of more than $40 \%$ organic matter; OM; expressed as $\mathrm{mm} \mathrm{yr}^{-1}$ ) is calculated separately from the carbon accumulation rate (CAR; annual deposition rate of grams of carbon per unit peat area per unit time; expressed as $\mathrm{g} \mathrm{C} \mathrm{m}^{-2} \mathrm{yr}^{-1}$ ). The differentiation between PAR and CAR as in Hapsari et al. (2017) is similarly applied in this study. 
The Sungai Buluh peatland initiated around 13,400 cal yr BP and initially formed as a topogenous peat deposit (LOI $\leq 75 \%$; Anderson, 1961) with a mixed-riverine forest dominating the site. During its topogenous phase, Sungai Buluh peatland was strongly influenced by the flood pulse of the adjacent river caused by rising sea levels in the early Holocene and a period of increased precipitation in the mid-Holocene. This caused strong fluctuations in the water table of Sungai Buluh, increased oxygen supply into the ecosystem and triggered rapid aerobic OM decay. Consequently, during its topogenous phase, the PAR and CAR of the Sungai Buluh peatland were low.

Coinciding with the regression of sea level and a reduction of precipitation in the late Holocene, the influence of the adjacent river on the Sungai Buluh peatland was reduced. The reduction in flood frequency suppressed the growth of riverine vegetation by reducing nutrient supply and groundwater replenishment. Moreover, increasing acidification of the environment due to the accumulation of decaying OM harmed the riparian vegetation. This allowed the hydrophytic peat-swamp vegetation to flourish and resulted in the establishment of a peat-swamp forest at around 1200 cal yr BP. Reduced flooding also led to a more stable water level which limited the oxygen supply and thwarted $\mathrm{OM}$ decomposition. In turn, this accelerated $\mathrm{OM}$ accumulation and supported the development of an ombrogenous peatland, as suggested by high accumulation rates of peat and $\mathrm{C}$ and the absence of river sediment input from $1200 \mathrm{cal}$ yr BP onwards.

\subsection{Materials and methods}

To examine whether the people of the Malayu Empire conducted any activities in the Sungai Buluh peatland and whether the peatland maintained its structure (i.e. floristic 
composition) and function as a $\mathrm{C}$ sink despite the anthropogenic disturbances, and returned to its pre-disturbance condition, we assess the changes in past vegetation, CAR and fire regimes using the SB-B core taken from Sungai Buluh peatland (Hapsari et al., 2017; detailed methods are provided in Appendix S1). The past vegetation of Sungai Buluh was examined using pollen and spore data with the assumption that the assemblages of pollen and spores in the core generally reflect the vegetation of the surrounding area at the time of their deposition (Bradley, 1999). Pollen and spores were extracted using the standard method (Faegri \& Iversen, 1989), counted to 300 pollen grains and identified to the finest taxonomical classification possible using the available literature (e.g. Pollen and Spore Image Database of the University of Goettingenavailable at http://gdvh.uni-goettingen.de/;Anderson \& Muller, 1975; Jones \& Pearce, 2015). The identified pollen taxa are grouped according to their life form: (1) trees/shrubs and (2) herbs/subshrubs (i.e. vegetation that has characteristics of both herbaceous and woody plants). The pollen and spore data is presented in the pollen diagram prepared using C2 software (Juggins, 2007). Only the taxa with notable changes during the occupation period of the Malayu Empire and those that serve a special purpose (i.e. species representative of a specific use or changes in land use/cover) are shown.

The Sungai Buluh CAR ( $\left.\mathrm{g} \mathrm{C} \mathrm{m}^{-2} \mathrm{yr}^{-1}\right)$ was calculated using the following equation (Tolonen \& Turunen, 1996), where BD is the peat bulk density $\left(\mathrm{g} \mathrm{m}^{-3}\right), \% \mathrm{C}_{\mathrm{org}}$ is the total organic $\mathrm{C}$ content, and PAR is the peat accumulation rate $\left(\mathrm{mm} \mathrm{yr}^{-1}\right)$.

$$
C A R=B D \times \% C_{\text {org }} \times \text { PAR }
$$

The past fire regime was examined using macro-charcoal analysis. This analysis is based on the assumption that macroscopic $(>150 \mu \mathrm{m})$ charcoal particles represent the 
occurrence of local fires, as such particles tend to deposit near their originating fires, being too large for many forms of transport to carry them far (Higuera et al., 2009). For this analysis, the subsamples were prepared using the method developed by Rhodes (1998) and Stevenson \& Haberle (2005). Large charcoal particles $(>150 \mu \mathrm{m})$ were counted and analysed using CharAnalysis (Higuera et al., 2009). The past fire frequency was inferred from the identified fire peaks. These peaks were isolated by dividing charcoal accumulation rate (CHAR) into 'background' and 'peak' components and separating the 'peaks' into 'fire peaks' and 'noise' using a defined threshold (detail presented in Appendix S1).

The results are subsequently divided into three zones: I. Pre-Malayu Empire, II. Malayu Empire and III. Post- Malayu Empire, whose boundaries are based on the occupation period in Muara Jambi. These boundaries chronologically follow the SB-B age-depth model based on calibrated ${ }^{14} \mathrm{C}$ ages (Fig. 3.2; Appendix S1). As for the SB-B chronology, this study expresses the age in years before present (yr BP).

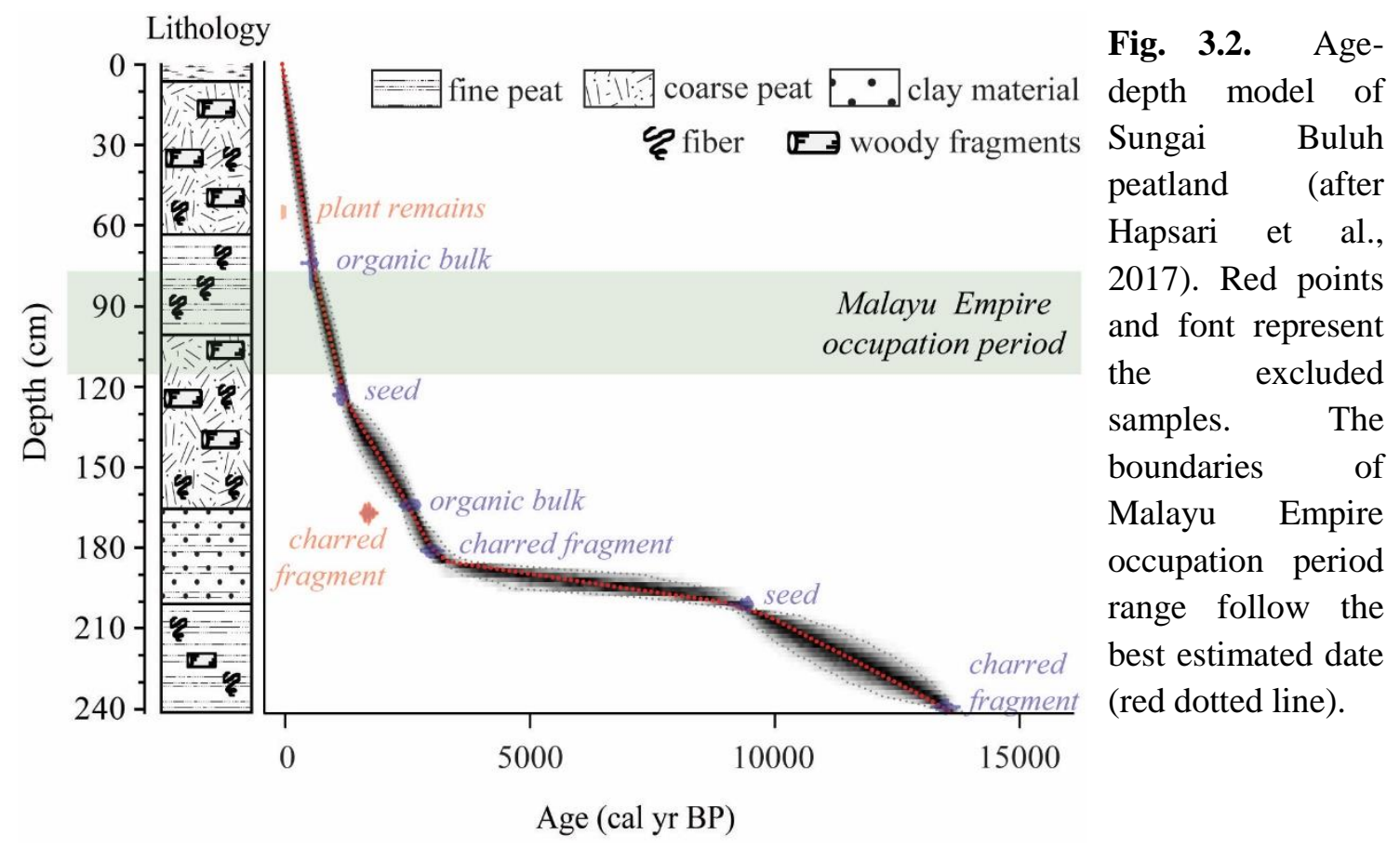


The exact starting date of Malayu Empire occupation in Muara Jambi is, however, not available. According to Boechari (1985), the Muara Jambi temple complex was built somewhere "between the middle of the $9^{\text {th }}$ and the early $10^{\text {th }}$ century". This date is circumstantial, as it was proposed based on the similarity of the character found in the inscription of Muara Jambi with the "Kawi" script that was used during the same range of time (Boechari, 1985; J. Miksic, pers. comm. 24 April 2017). We converted this 'century' date into yr BP and divided the 'early', 'middle' and 'late' century periods into ' $(\mathrm{x}) 00-(\mathrm{x}) 35$ ', '( $\mathrm{x}) 35-(\mathrm{x}) 65$ ' and ' $(\mathrm{x}) 65-(\mathrm{x}+1) 00$ '. The estimated starting date of Malayu Empire occupation therefore ranges from 835 to 935 AD (1115 to $1015 \mathrm{yr} \mathrm{BP}$ ) which, according to the age-depth model of the SB-B core, occurs at a depth of 109-117 cm (Fig. 3.2). Conversely, the exact date when the Empire was moved to the hinterland was previously reported to be 1347 AD (603 yr BP; Witrianto, 2014) which falls around a depth of $77.5 \mathrm{~cm}$ in the core (Fig. 3.2). We therefore set the boundaries of zone II (Malayu Empire) based on the occurrence of human activity indicators within the occupation period range of the Malayu Empire and the site abandonment date.

To assess the impact of human activities on the $\mathrm{C}$ sequestration ability during the Malayu Empire, the pre-, during and post- Malayu Empire, PAR and CAR of Sungai Buluh peatland were statistically compared by calculating the average rates during each period in $\mathrm{R}$ ( $\mathrm{R}$ Core Team, 2014). The average PAR and CAR during the topogenous and ombrogenous phases in the pre-Malayu Empire zone were also differentiated.

The trends in floristic composition of Sungai Buluh were analysed using a principle component analysis (PCA) of pollen percentage data in R. Square root data transformation was applied prior to ordination to minimise biases arising due to differential pollen productivity, dispersal and preservation. 


\subsection{Results}

\subsubsection{Palaeoenvironmental data}

Zone I. Pre-Malayu Empire (240-112 cm; ca. 13,400-1050 cal yr BP) covers the entire topogenous phase and part of the ombrogenous phase of the Sungai Buluh peatland. This zone was characterised by domination of trees/shrubs pollen (average $96 \%$; the following values are also averages), with a low percentage of herbs/subshrubs pollen (4 $\%$; Fig. 3.3). In this zone, the average charcoal concentration was 86 particles $\mathrm{cm}^{-3}$ while the average charcoal accumulation rate (CHAR) was 1 particle $\mathrm{cm}^{-2} \mathrm{yr}^{-1}$. A total of 20 charcoal peaks were identified in this zone, with a low average fire frequency ( 2 fire events in 1000 years; Fig. 3.4).

Zone II. Malayu Empire (112-77.5 cm; ca. 1050-600 cal yr BP) was characterised by a decrease in the total average of trees/shrubs pollen from 96 to $74 \%$, accompanied by an increasing proportion of herbs/subshrubs pollen from 4 to $26 \%$ (Fig. 3.3). In this zone, pollen of Piperaceae, Poaceae, Ardisia and Grewioideae increased significantly. The average charcoal concentration slightly decreased to 63 particles $\mathrm{cm}^{-3}$ and the average CHAR increased to 5 particles $\mathrm{cm}^{-2} \mathrm{yr}^{-1}$. Only one charcoal peak was identified, with no change observed in the average fire frequency (2 fire events in 1000 years; Fig. 3.4).

In the beginning of zone III. Post-Malayu Empire $(77.5-0 \mathrm{~cm}$; ca. $600 \mathrm{cal} \mathrm{yr}$ BP to present), the pollen percentages of Poaceae and Grewioideae reached their highest values (16 and $7 \%$ ), whereas other herbs/subshrubs pollen decreased to $4 \%$ (Fig. 3.3). At around 450 cal yr BP, the proportion of Poaceae and Grewioideae pollen decreased to $2 \%$, followed by an increase of trees/shrubs pollen to $93 \%$, while other herbs/subshrubs made up $5 \%$. In this zone, both averages of charcoal concentration and CHAR increased to 137 particles $\mathrm{cm}^{-3}$ and 17 particles $\mathrm{cm}^{-2} \mathrm{yr}^{-1}$, respectively. Two 
charcoal peaks were detected and the average fire frequency slightly increased to 3 fire events in 1000 years (Fig. 3.4).

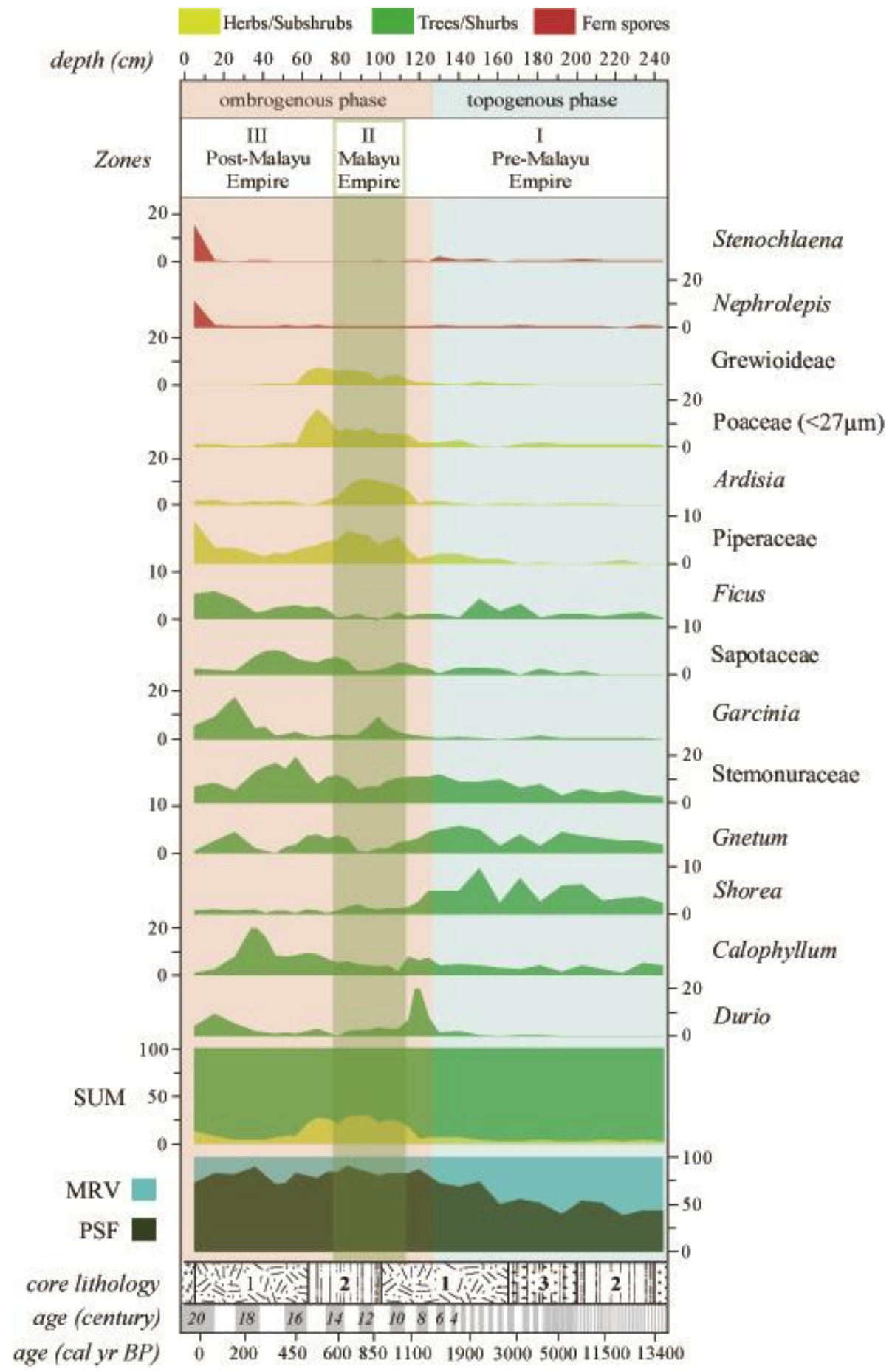

Fig. 3.3. Pollen diagram of the Sungai Buluh. Selected taxa are displayed. All values are in percentages (\%). Numbers in the lithology column represent the following peat characteristics (1) coarse peat; (2) fine peat; (3) fine peat with clay. Each of the grey and white bar on age(century) represents 100 years. The proportion of mixed-riverine (MRV) and peat-swamp forest (PSF) of Sungai Buluh is calculated based on the total MRV and PSF pollen (after Hapsari et al., 2017). 


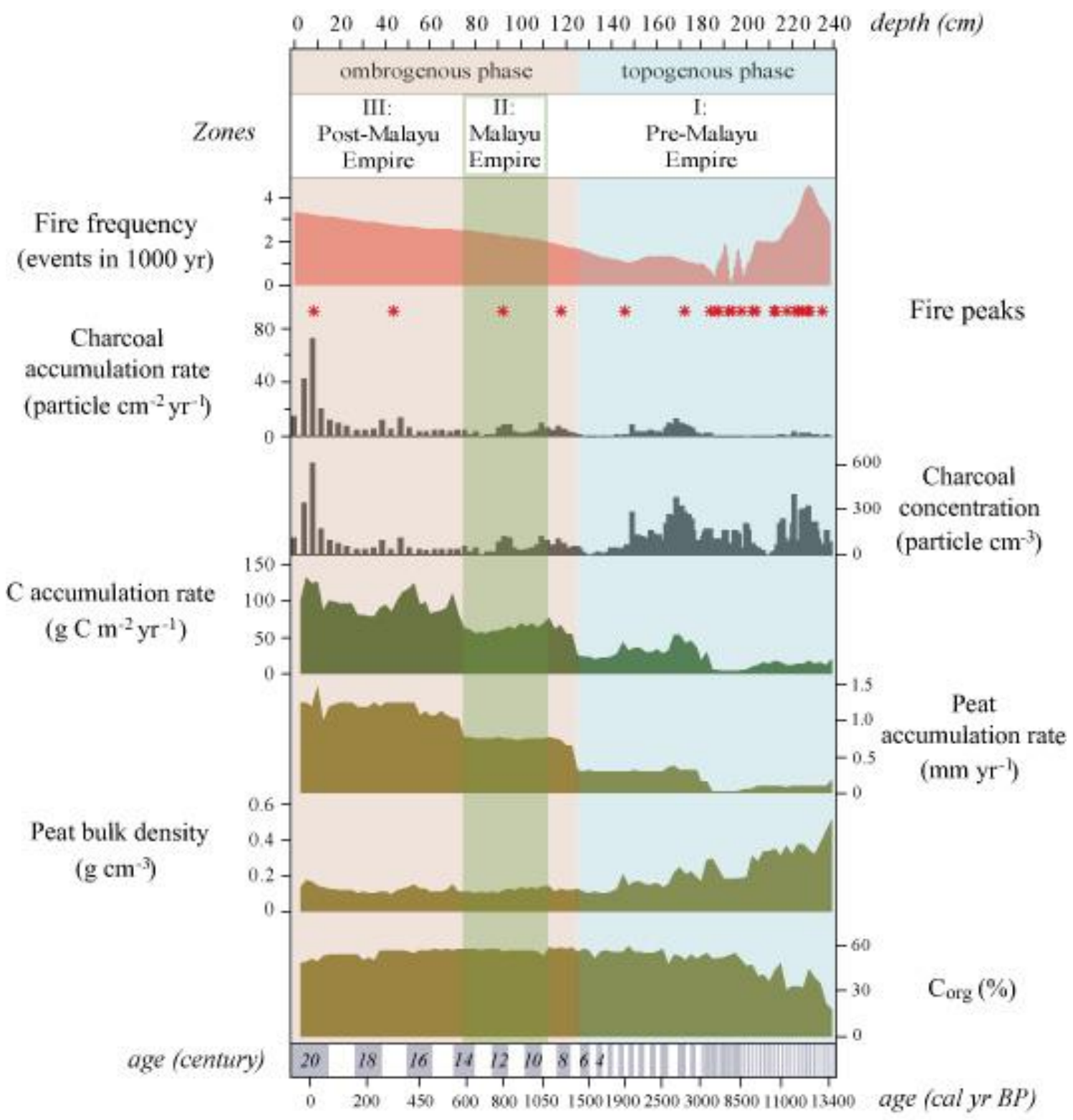

Fig. 3.4. $\mathrm{C}_{\text {org }}$, peat bulk density, peat accumulation rate (PAR), $\mathrm{C}$ accumulation rate (CAR) and charcoal analysis results for the Sungai Buluh record (after Hapsari et al., 2017). Each grey and white bar on age-century represents one hundred years.

\subsection{Carbon accumulation rate $(C A R)$}

Initially, the CAR of Sungai Buluh peatland can be differentiated according to its development into a topogenous and an ombrogenous phase (Hapsari et al., 2017). Peatlands accumulate peat and $\mathrm{C}$ slowly during the topogenous phase and then at much higher rates during the ombrogenous phase (Page et al., 2011; Hapsari et al., 2017). 
Before the occupation period of the Malayu Empire and during its topogenous phase, the PAR and CAR of Sungai Buluh peatland were low (average $0.2 \mathrm{~mm} \mathrm{yr}^{-1}$ and $25 \mathrm{~g} \mathrm{C}$ $\mathrm{m}^{-2} \mathrm{yr}^{-1}$; Fig. 3.4 and 3.5). The rates then increased to $0.8 \mathrm{~mm} \mathrm{yr}^{-1}$ and $69 \mathrm{~g} \mathrm{C} \mathrm{m}^{-2} \mathrm{yr}^{-1}$, respectively, during the ombrogenous phase at around 1200 cal yr BP. The CAR decreased slightly around the occupation period of the Malayu Empire to $62 \mathrm{~g} \mathrm{C} \mathrm{m}^{-2} \mathrm{yr}^{-1}$ (Fig. 3.4 and 3.5). Following site abonnement after the demise of the Malayu Empire, the PAR and CAR of Sungai Buluh increased to $1.2 \mathrm{~mm} \mathrm{yr}^{-1}$ and $96 \mathrm{~g} \mathrm{C} \mathrm{m}^{-2} \mathrm{yr}^{-1}$, respectively (Fig. 3.4 and 3.5).

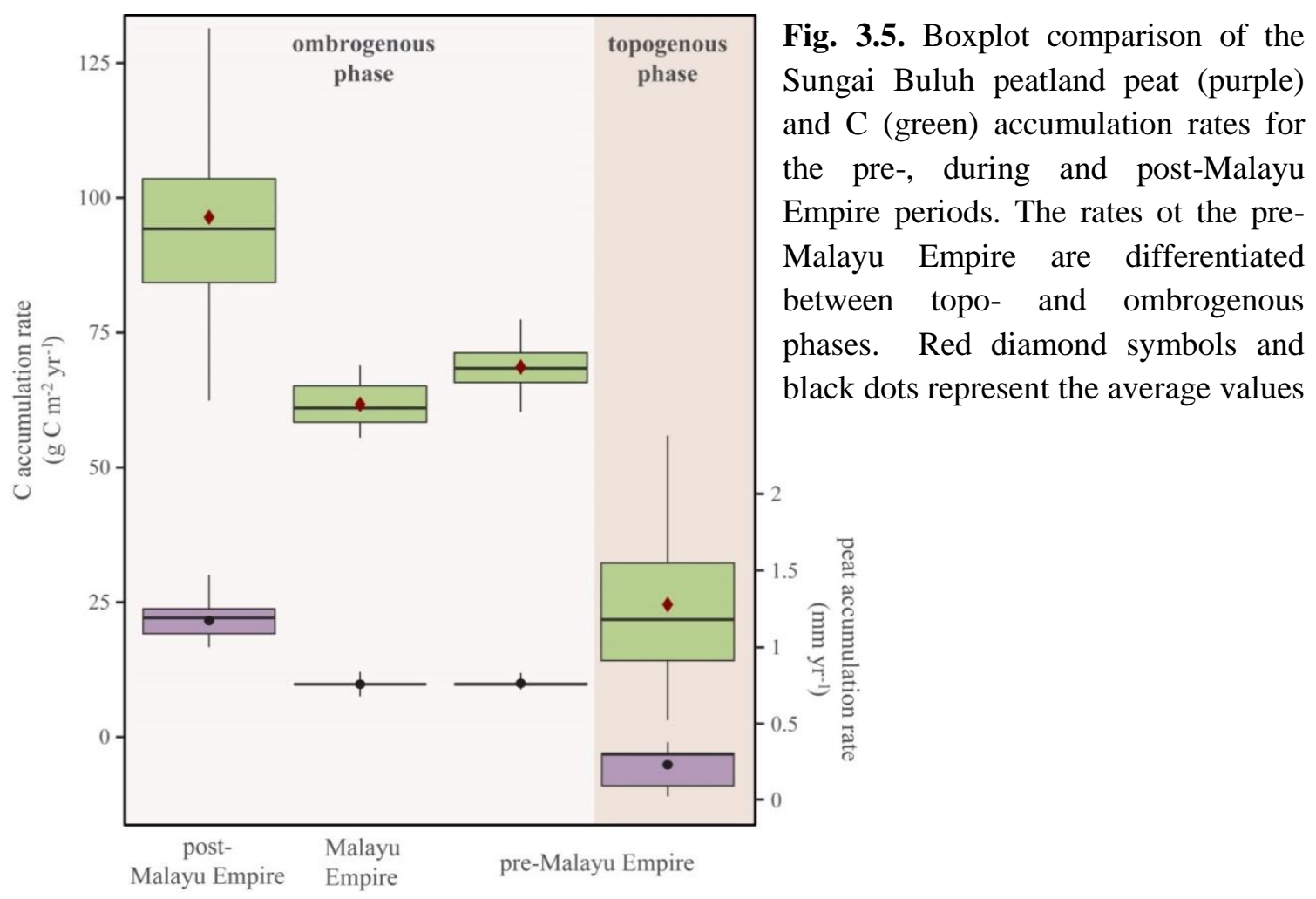

\subsection{Trends in floristic composition of Sungai Buluh}

PCA results based on pollen and spore data demonstrate the characteristics of taxa assemblage and reveal changes in vegetation over time (Fig. 6). The first and second axes of the PCA (PC1 and PC2) represent the two main factors of vegetation changes that explain $41 \%$ and $10 \%$ of the total variance in the data. PC1 can be interpreted as 
the development stage of Sungai Buluh peatland, whereas PC2 likely represents the disturbance phase. The PCA plot for the Sungai Buluh record samples shows a clear separation between three phases of vegetation composition: mixed-riverine forest, peatswamp forest and forest opening. The pattern indicates a change of vegetation from mixed-riverine forest to peat-swamp forest around $1200 \mathrm{cal} \mathrm{yr} \mathrm{BP}$ and later an alteration towards Poaceae, Ardisia and Grewioideae at 1050 cal yr BP. The PCA pattern subsequently shifted back to peat-swamp forest at 430 cal yr BP.

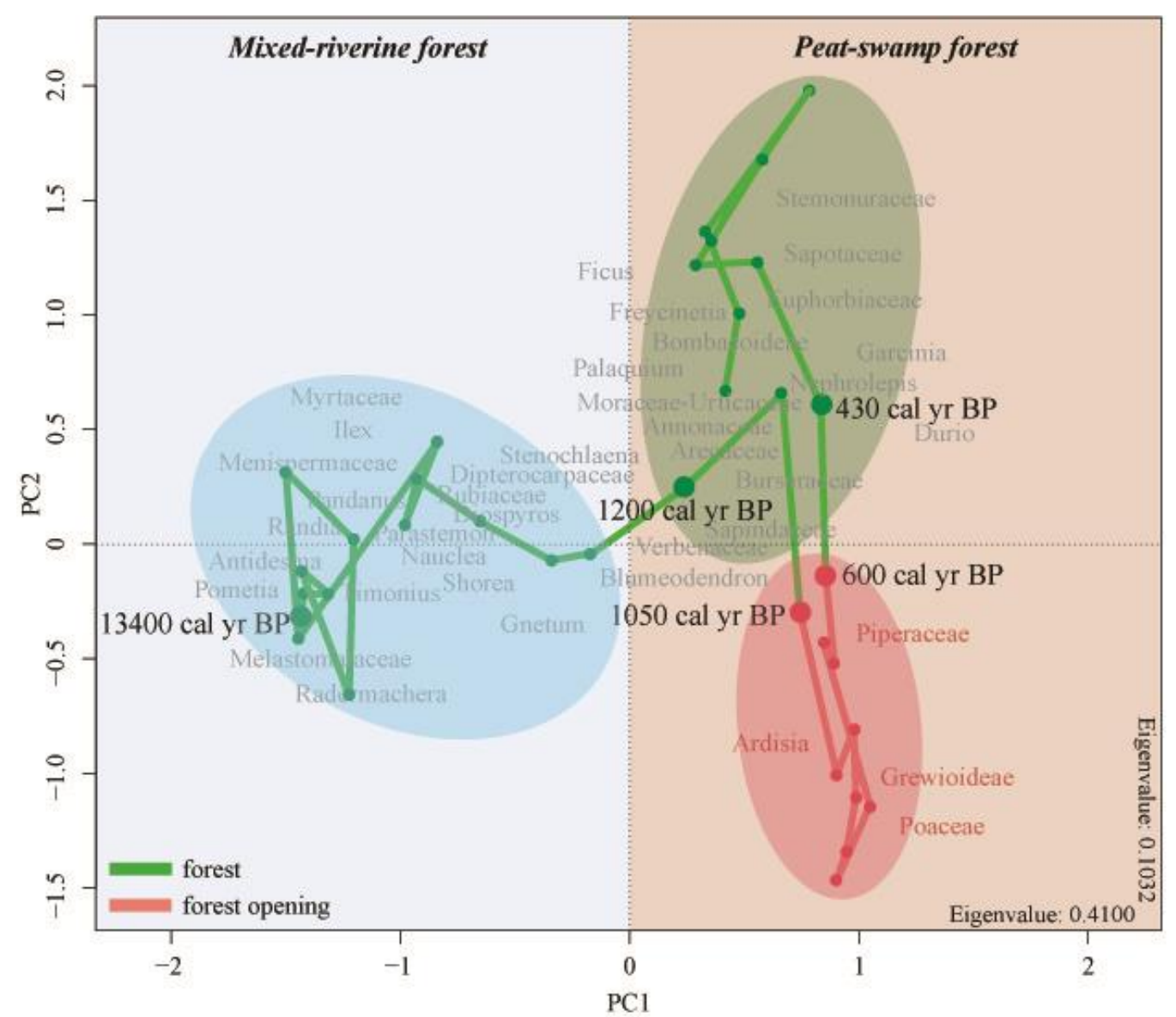

Fig. 3.6. PCA plot for Sungai Buluh display the taxa assemblage and the trend in vegetation change. Green dots represent the forest cover while red dots depict the forest opening. The circles represent three different phases of Sungai Buluh vegetation: mixed-riverine forest (blue), peat-swamp forest (green) and forest opening (red). PC1 can be interpreted as the development stage of the Sungai Buluh peatland, whereas PC2 likely represents the disturbance phase. 


\subsection{Discussion}

\subsubsection{Human activities and their impacts on peatland}

Before the Malayu Empire occupation period, the forest cover of the Sungai Buluh peatland was dense, as indicated by the domination of trees and shrubs pollen in the diagram (Fig. 3.3). The Sungai Buluh forest was initially dominated by mixed-riverine vegetation. Due to fewer river floods following the late Holocene sea level regression, Sungai Buluh forest cover gradually shifted towards peat-swamp forest, which was fully established at 1200 cal yr BP (Fig. 3.3; see Section 2.2).

Sungai Buluh forest cover declined after the establishment of Muara Jambi temple, as shown by the decrease in the proportion of pollen from peat-swamp taxa, such as Shorea, Durio, Gnetum, Calophyllum and Garcinia (Fig. 3.3), and confirmed by a similar decline in their absolute terms (i.e. pollen concentration; Appendix S2). The proportion of Stemonuraceae also decreased slightly (Fig. 3.3). This decline was accompanied by an increase of Piperaceae, Poaceae, Ardisia and Grewioideae which usually grow in disturbed areas due to logging, cattle grazing, road building and/or forest clearing (e.g. Chung, 2006; van Eijk et al., 2009; Lim, 2012; Padmanaba \& Sheil, 2014).

Shorea, Durio and Calophyllum trees are well-known timber plants commonly used for construction, boats and furniture (Soerianegara \& Lemmens, 1994; Lemmens et al., 1995). Their wood is easy to work with and highly durable (Soerianegara \& Lemmens, 1994; Lemmens et al., 1995). Garcinia is used as an alternative timber plant for temporary constructions, furniture and decoration (Sosef et al., 1998). The wood of Garcinia is easy to work with and durable, but it often shrinks with age (Sosef et al., 1998). On the other hand, Stemonuraceae are preferably used as charcoal wood and are 
less popular as timber trees, likely due to their low durability and because their wood is very hard to work with (Sosef et al., 1998).

Considering that the tree taxa which exhibited a pronounce decline in absolute and proportional abundance following the establishment of Muara Jambi temple are commonly used for timber (Soerianegara \& Lemmens, 1994; Lemmens et al., 1995; Sosef et al., 1998), it is conceivable that the opening in forest vegetation resulted from logging and timber harvesting. According to an ancient text written by Chau Ju-Kua in $1225 \mathrm{AD}$, the inhabitants of Muara Jambi utilised the available natural resources such as woods, rattan or palm leaves to construct their houses (Hirth \& Rockhill, 1966; TjoaBonatz et al., 2009). Moreover, the people of the Malayu Empire were not an egalitarian society, which means that there was a need to show their social status by constructing elite houses with massive and detailed ornamentation (Tjoa-Bonatz et al., 2009; Alam, 2014). This may have also led to the use of timber for decorative purposes. Also, taking into account that connections and trade between the capital Muara Jambi and the surrounding settlements and communities were accommodated through the river (TjoaBonatz et al., 2009; Alam, 2014), it is also conceivable that the wood was used in construction of boats and trading ships.

Ardisia is a plant that commonly grows rapidly on grazing grounds (Hoogerwerf, 1970). Unlike most species of wild Poaceae and herbaceous Grewioideae such as Corchorus that are usually grazed by animals or cut as livestock fodder (Humphreys, 1991; Quattrocchi, 2012; Ali et al., 2014), Ardisia is unpalatable due to the high alkaloid content in the leaves that results in a bitter taste and potential toxicity at higher intakes (Johnsingh, 2004; Ong, 2004; Dolan et al., 2010). Thus, whenever grasses and other herbs are grazed or cut for fodder, the reduced competition for light, nutrients and other 
resources favours the growth of Ardisia (Koop, 2004). The abundance of Ardisia pollen in the record thus indicates grazing or cut-and-carry (a fodder system in which the grasses and herbaceous plants are cut from the field and delivered to confined livestock) activities conducted by people of the Malayu Empire in the Sungai Buluh peatland.

Although the history of livestock in Indonesia was already documented since the $4^{\text {th }}$ century in ancient inscriptions and texts, historical records of livestock raising in the Malayu Empire is not available. In ancient inscriptions of the Kutai Kingdom in Borneo $\left(4^{\text {th }}-14^{\text {th }}\right.$ century), for instance, it was described that King Mulawarman of Kutai donated thousands of cows to the Brahmin priests (Poerbatjaraka, 1952). A Chinese ancient text also described that people of the Nagur Kingdom, North Sumatra $\left(5^{\text {th }}-12^{\text {th }}\right.$ century), bred and raised livestock for personal consumption (Damanik, 1974). Currently, goat, buffalo and cow grazing are common practices in SE Asian peatlands, with Palangkaraya, Kalmantan (Setianah et al., 2004) and in Phru Kuan Kreng, Thailand (Sundari, 2005) being prime examples.

According to the historical record, the Malayu Empire economy was primarily based on fishing, collection of forest and ocean products, and trading of goods through a regional trading centre such as Muara Jambi (Andaya, 1993). This empire was also very well known as the largest pepper (Piper sp. Family: Piperaceae) centre of Sumatra (Witrianto, 2014). Even though no clear documentation remains regarding the type of forest goods and what kind of forest they were taken from, or whether pepper was amongst the nontimber forests products (NTFP), it is feasible that the Malayu Empire population benefitted from the increase of Piperaceae by conducting wild-harvesting activities in the Sungai Buluh peatland. 
Records of human activities in SE Asian peatlands such as Danau Sentarum, Borneo (Anshari et al., 2001), Sikijang swamp, Sumatra (Flenley \& Butler, 2001), Kutai peatland, Borneo (Hope et al., 2005) and Loagan Bunut, Sarawak-Borneo (Hunt \& Premathilake, 2012) are mainly based on the abundance of charcoal. Increased charcoal deposition in those records were interpreted as resulting from arboriculture activities (Hunt \& Premathilake, 2012), slash-and-burn agriculture (Flenley \& Butler, 2001) and fishing (Hope et al., 2005). However, charcoal increases in those records could have also resulted from repeated natural fires (Anshari et al., 2001; Flenley \& Butler, 2001). In contrast to the above human activity records, the charcoal concentration and fire frequency in the Sungai Buluh record were low during the Malayu Empire period (Fig. 3.4). The proportion of Nephrolepis and Stenochlaena, which vigorously grow on peatlands following fire disturbances, were also very low during this period (Fig. 3.3; Wösten et al, 2008). This suggests that the Malayu Empire population did not use fire extensively for ground clearance or slash-and-burn activities.

In the Sungai Buluh record, pollen of cultivated Poaceae, e.g., rice (Oryza sativacomplex; $>42 \mu \mathrm{m}$; Chaturvedi et al., 1998), corn (Zea mays; $>58 \mu \mathrm{m}$; Skvarla $\&$ Larson, 1966), sugar cane (Saccharum sp.; >36 $\mu \mathrm{m}$; Chaturvedi \& Datta, 2001) and wheat (Triticum sp.; $>49 \mu \mathrm{m}$; Cetl, 1960) are lacking. All Poaceae pollen grains found in our samples are $<27 \mu \mathrm{m}$ in size, indicating they are from wild grasses (Page, 1978; Köhler \& Lange, 1979; Dickson, 1988). This suggests that inhabitants of the Malayu Empire did not utilise the peatland for agricultural purposes.

During the Malayu Empire occupation period, there was approximately $10 \%$ lower CAR compared to the previous ombrogenous phase (Fig. 3.4 and 3.5). Initially, during the topogenous phase, CAR of Sungai Buluh was low due to a strong water table 
fluctuation (see Section 2.2). However, as the water table stabilised, OM accumulation in Sungai Buluh accelerated, resulting in the establishment of an ombrogenous peatland with rapid C accumulation around $1200 \mathrm{cal}$ yr BP (see Section 2.2).

The activities conducted by inhabitants of the Malayu Empire caused a reduction in Sungai Buluh forest cover (Fig. 3.3). A decline in forest cover can negatively affect an ecosystem's net primary productivity (NPP; Clark et al., 2001; Gautam \& Mandal, 2016). Also, herbs and grasses that grow on logged or disturbed forest floors, have slower turnover rates of fine roots (Cheplick, 1998), which are a major contributor to the CAR in tropical peatlands (Chimner \& Ewel, 2005). Moreover, the shift in composition from woody plants to herbs and grasses can reduce the input of recalcitrant litter, which increases OM decomposability (Silver \& Miya, 2001; Chimner \& Ewel, 2005; Hapsari et al., 2017). Although a harvested or logged forest can receive high pulses of lignin-rich OM through the accumulation of on-site woody wastes such as sticks and wood chips (Liu et al., 2006), their contribution is still lower than the total biomass input from living vegetation (Clark et al., 2002). Therefore, the slight decrease in CAR observed in the ombrogenous Sungai Buluh peatland during the Malayu Empire occupation period likely resulted from a lower NPP and litter quality concomitant with forest opening (Hapsari et al., 2017).

Despite the reduction of NPP and lignin-rich OM input, the decrease in Sungai Buluh's CAR during the Malayu Empire occupation period can be considered minor. Considering that the CAR in tropical peatland is a result of the interplay between NPP, litter quality and slow anaerobic decay (Sjögersten et al., 2014), the water-saturated conditions of the Sungai Buluh peatland must have been maintained to ensure OM preservation during the Malayu Empire occupation. This, in turn, suggests that 
logging/timber harvesting, grazing/cut-and-carry and wild-harvesting activities conducted by the Malayu Empire did not significantly alter Sungai Buluh peatland hydrology. The persistence of Sungai Buluh peatland C sequestration, despite a slight decrease during the Malayu Empire occupation, also demonstrates that human activities do not always abolish all ecosystem functions.

\subsubsection{Peatland response to human disturbance}

After the conquest by Majapahit in the $14^{\text {th }}$ century, the Malayu Empire was ruled by an official of the Majapahit court, namely Adityawarman. The empire then became a vassal of Majapahit until Adityawarman declared his independence in 1347 AD and subsequently moved the Empire to Saruaso, West Sumatra (Witrianto, 2014; Kozok \& van Reijn, 2010). Following the abandonment of the site, the forest of the Sungai Buluh peatland regenerated as indicated by an increase of trees/shrubs pollen (Fig. 3.3).

Human activities might impair the forest's ability to regenerate or recover (Newton \& Tejedor, 2011). For instance, logging decreases the abundance of mature trees, increases pollination distance and enhances the risk of inbreeding (Ghazoul, 2005; Carneiro et al., 2009; Tambarussi et al., 2017). Grazing hinders forest regeneration by reducing seedling growth and survival, as young plants are consumed or trampled (Navroodi, 2015). Collection of non-timber forest products such as fruits or nuts can also increase “seed-predation" and subsequently reduce seed availability (Murali et al., 1996).

Thus, the site abandonment with subsequent cessation of human activities in Sungai Buluh might explain the high proportions of Poaceae and Grewioideae which accompanied the decrease of Ardisia between 600 and 450 cal yr BP (Fig. 3.3). According to Bruijnzeel et al. (2010), grasses and other palatable plants can grow 
vigorously once grazing is discontinued. The cessation of grazing/cut-and-carry activities in Sungai Buluh peatland allowed Poaceae and Grewioideae to expand, resulting in increasing competition for Ardisia which suppressed its growth (Koop, 2004).

Additionally, the cessation of human activities in Sungai Buluh allowed the forest to regenerate/recover which was initiated by the growth of rapidly regenerating trees such as Gnetum, Calophyllum, Sapotaceae and Ficus (Fig. 3.3; Soerianegara \& Lemmens, 1994; Manner \& Elevitch, 2006; Gunawan et al., 2012; Cottee-Jones et al., 2016). Gnetum is a taxon which is able to resprout (Bullecer \& Bullecer, 2011). This taxon and the taxon Calophyllum can reproduce more than once per year and produce around 100 kg seeds annually, with a high seed viability and relatively fast germination (3-12 months; Cadiz \& Florido 2001; Friday \& Okano, 2006; Manner Elevitch, 2006; Kumar et al., 2015). Moreover, Calophyllum exhibits a high rate of seed germination and seedling survival ( $>90 \%$ and $\sim 100 \%$; Friday \& Okano, 2006). Compared to Calophyllum, the seed germination and seedling survival rates of Ficus (50-75\% and $\sim 10 \%$, respectively) are lower (Kuaraksa \& Elliott, 2013). However, it seems that the reproduction of Ficus is compensated for by the enormous numbers of seeds produced (>100 seeds/fruit) in addition to its resprouting ability (Sosef et al., 1998; Howe, 2016). The fleshy-fruits of Ficus are also attractive to frugivorous animals such as birds or bats, which enhances the effectiveness of its seed dispersal (Cottee-Jones et al., 2016). Sapotaceae also produce fleshy-fruits that attract frugivorous animals and their rates of seed germination and seedling survival are high (75-85\% and $92 \%$, respectively; Soerianegara \& Lemmens, 1994; Mizuno et al., 2016). 
Forest regeneration/recovery processes begin with colonisation (Chazdon, 2014). The success of this phase relies upon several factors, such as seed availability, the role of remnant vegetation, dispersal effectiveness and post-dispersal seed fate (Guariguata \& Ostertag, 2001). Considering the regrowth of Sungai Buluh peat-swamp forest, it is likely that the pre-requisites for successful colonisation of forest gaps/openings in this peatland were met. The resprouting ability and seed production, effective seed dispersal by animals as well as excellent seed germination and seedling survival of Gnetum, Calophyllum, Sapotaceae and Ficus likely favoured the colonisation of gaps/openings in the Sungai Buluh peat-swamp forest during its regeneration/recovery process.

The next stage of the forest regeneration/recovery process is species accumulation (Guariguata \& Ostertag, 2001; Chazdon et al., 2007). During a natural recruitment, species will accumulate gradually (Chazdon et al., 2007). It may take decades for the forest to reach a floristic composition that is similar to that of an old-growth forest, although it is often questioned whether the forest regrowth will ever converge with the initial floristic composition (Finegan, 1996; Guariguata \& Ostertag, 2001; Chazdon, 2003; Chazdon et al., 2007). Based on the PCA analysis of the Sungai Buluh pollen data, the regrowth of the peat-swamp forest returned to its initial floristic composition at 430 cal yr BP (Fig. 3.6). This suggests that the natural recruitment in Sungai Buluh was successful, likely due to sufficient seed sources and the sufficient remaining vegetation from the old-growth forest following the disturbance (Saldarriaga et al., 1988; Finegan, 1996).

Some species, however, may fail to recruit (Chazdon et al., 2007; Clark, 2009). In Sungai Buluh's case, Shorea was not able to regrow (Fig. 3.3). This result is in agreement with other studies showing limited regeneration of Shorea, such as in the 
Pelalawan peatland, Riau, Sumatra after wind disturbance (Gunawan et al., 2007) and in Sungai Damit peatland, Darussalam, Brunei after logging operations (Kobayashi, 2000). Although the seedling survival rate of Shorea is reportedly high (80-90 \%; Wibisono \& Gandrung, 2008), Shorea is an insect-pollinated species that suffers from limited pollination (Ghazoul, 1998; Masuda et al., 2013). Trigona bees, the main pollinator of Shorea, are weak fliers (Masuda et al., 2013). The increasing distance between flowering Shorea trees due to logging or tree fall thus limits the movement and hence the pollination success of Trigona (Ghazoul, 1998). Moreover, as the seeds of Shorea are edible and energy rich, their reproductive success is probably low owing to the high risk of seed predation by vertebrates and invertebrates in both pre- and post-seed dispersal phases (Ghazoul, 2016). Thus, the restricted regeneration of Shorea in the Sungai Buluh, the Pelalawan and the Sungai Damit peatlands are likely related to the above limitations during their early recruitment stage (i.e. seed production and survival). The recovery of Sungai Buluh thus raises a question: how long did it take for the forest to return to its previous floristic composition? Sungai Buluh forest recovered at around 430 cal yr BP (Fig. 3.6). Considering that the site of Muara Jambi temple complex was abandoned at $603 \mathrm{cal} \mathrm{yr} \mathrm{BP,} \mathrm{it} \mathrm{is} \mathrm{estimated} \mathrm{that} \mathrm{the} \mathrm{recovery} \mathrm{process} \mathrm{of} \mathrm{Sungai} \mathrm{Buluh}$ forest took around 170 years. Taking dating uncertainties into account, the estimated forest recovery time ranges from 75 to 300 years.

The recovery time of the Sungai Buluh peat-swamp forest is in the same range as the 150-year recovery time of a lowland forest in Guatemala after Mayan polities dissolved (Islebe et al., 1996) and the 200-year average recovery time of global tropical forests derived from 71 palaeoecological records (Cole et al., 2014). However, the context of 'recovery' in those studies is only defined as "increased abundance of forest taxa" 
(Islebe et al., 1996) and "the maximum percentage of forest pollen in the displayed pollen sum after a decline, before a stabilising point or further decline" (Cole et al., 2014), without clear annotations indicating whether or not the return of the previous floristic composition was achieved. Moreover, the recovery time in Cole et al. (2014) was not restricted to forests subjected to anthropogenic disturbance, but also included those subjected to natural disturbances such as hurricane and drought.

Forest recovery from human disturbances might take longer than from natural causes (Cole et al., 2014). Compared to the natural factors, human activities can cause more severe disruption in forest structure and composition that might also limit forest recovery, such as a reduction in seed availability, an increase in the distance of seed sources, or changes to the community of seed-dispersing fauna (Chazdon, 2003). In some cases, human activities can also impact soil properties by causing compaction and nutrient leaching (Chazdon et al., 2007). Following severe human disturbances, it may take centuries for forests to fully recover (Chazdon et al., 2007). For instance, neotropical forests in Colombia, Venezuela and Panama still do not converge with their previous floristic composition even after 80-100 years of succession following grazing and slash-and-burn agriculture (Saldarriaga et al., 1988; Denslow \& Guzman, 2000). The recovery time of Sungai Buluh, however, cannot be compared specifically to those of other anthropogenically disturbed tropical peat-swamp forests due to a lack of data. The study from Cole et al. (2015) that aimed to assess the resilience of coastal peatlands in Malaysia did not find any evidence of forest regeneration since the sites were first subjected to human disturbance at $500 \mathrm{cal}$ yr BP.

In contrast to the floristic composition, the Sungai Buluh CAR already began increasing around $540 \mathrm{cal}$ yr BP (Fig. 3.4), suggesting that the peatland capacity to sequester C had 
returned to its pre-disturbance state. The recovery time of this ecosystem function in Sungai Buluh is estimated to be on the order of 60 years, or ranging from immediate recovery to 130 years considering the dating uncertainties. Ecosystems are able to recover some of their functions before the recovery of their former floristic composition occurs, which may not happen, i.e. a different species composition may result postdisturbance (Guariguata \& Ostertag, 2001). For instance, the regeneration of any plants, regardless of the species, can enable important function to resume in the ecosystem such as soil stabilisation due to root growth (Guariguata \& Ostertag, 2001).

During the forest recovery process, biomass accumulation, particularly of leaves and fine roots, is brisk due to rapid seedling establishment and fast growth of saplings (Denslow \& Guzman, 2000; Guariguata \& Ostertag, 2001; Feshe et al., 2002; Letcher \& Chazdon, 2009). In tropical peatlands, fine root biomass largely contributes to the CAR due to their slow decomposition under waterlogged conditions, in addition to their high lignin content (Brady, 1997; Chimner \& Ewel, 2005). Thus, the rapid recovery of the C sink function of Sungai Buluh peatland is likely related to rapid fine-root biomass accumulation of juvenile forest vegetation during the forest recovery process. It is also inferred that the recovery time of individual ecosystem functions may vary, with recovery of the $\mathrm{C}$ sequestration function being faster than recovery of the floristic composition in the case of the Sungai Buluh peatland.

\subsection{Implication for tropical peatland conservation and restoration}

Understanding peatland resilience to human disturbances can assist in integrating local people and their socioeconomic needs into conservation and management strategies. This insight, in combination with adequate ecological knowledge, is essential for 
successful conservation programs (Muhumuza \& Balkwill, 2013). However, the records of human disturbance in tropical peatlands are sparse and evidence of peatland resilience to human disturbance is as yet not available. Thus, the palaeoecological record from Sungai Buluh provides the first evidence of tropical peatland resilience to anthropogenic disturbance by revealing recovery following the cessation of human activities (visualised in Fig. 3.7).

In Indonesia, conservation efforts often attempt to exclude the people and their activities from the targeted ecosystems (Mulyana et al., 2010). As the local people's livelihoods heavily depend on natural resources, such attempts caused conflicts between local people and practitioners. To overcome these conflicts, the interests of local people need to be accommodated by allocating some conservation areas to support the livelihood and interest of the local community (Mulyana et al., 2010). However, proper constraints on the use of natural resources need to be determined to ensure the sustainability of the ecosystems (Mulyana et al., 2010).

Determination of an 'acceptable' utilisation of peatland natural resources thus can imitate the type and magnitude of past human activities that have proven to be 'resilience-friendly,' meaning that the activities did not undermine ecosystem resilience. In the case of Sungai Buluh, the vegetation and $C$ sequestration ability were able to recover from past logging/timber harvesting, grazing/cut-and-carry and wild-harvesting because the hydrological conditions of the peatland were maintained. Therefore, similar or other activities that do not significantly alter peatland hydrology (i.e. high water table) could potentially be permitted on targeted peatland.

The intensity of the disturbance, on the other hand, is difficult to assess via palaeoecological records. Based on the changes in pollen proportion alone, Sungai 
Buluh was able to maintain its regenerative ability after a $30 \%$ decrease in forest cover. However, due to the differences in pollen production, dispersibility and preservation, this data cannot be used quantitatively without supporting information on pollen productivity and dispersal (Williams \& Jackson, 2003; Cole et al., 2015; Hjelle et al., 2015). Moreover, limits on wild-harvesting or NTFP collection to prevent seed predation cannot be determined from fossil pollen data.

Insights into ecosystem resilience to disturbances are also crucial for the success of restoration projects and can improve their efficiency and effectiveness in terms of cost and effort (Lake, 2013; Holl, 2017). Restoration is defined as 'the process of assisting the recovery of an ecosystem that has been degraded, damaged, or destroyed' (SER, 2004) with the major goal being to enhance ecosystem resilience (Lake, 2013). Understanding how ecosystems resist and/or recover from disturbances can thus help restoration projects select suitable techniques/approaches, develop plans, allocate resources and create realistic goals (Holl, 2017).

In Indonesia, peatland restoration is commonly carried out through rewetting and reforestation (BRG, 2016), which require the construction of canal blocks, water ponds, deep wells, nurseries and artificial mounds followed by seedling transportation (Giesen, 2004; BRG, 2016). Such efforts undoubtedly require a large amount of money, which is often not available (Giesen, 2004; BRG, 2016).

The evidence from Sungai Buluh suggests that a tropical peat-swamp forest can passively recover (without assistance), as long as certain prerequisites are met, including maintained hydrological conditions, the availability of seed sources (seed banks or remnant vegetation) and seed dispersers. Therefore, considering the high cost of tree planting on peatlands (US\$1100/ha; Graham et al., 2013), passive restoration can 
be an excellent solution if the current condition of the targeted peatland still fulfills the requirements for natural recovery. Tree planting thus can be restricted to poorregenerating taxa, such as Shorea in the Sungai Buluh peatland, or taxa with high economic value (Giesen \& van der Meer, 2009) if desired. Moreover, active restoration is defined to be less efficient than passive restoration, as it is costly, results in a less diverse forest and may negatively affect natural recovery by suppressing the growth of pioneer species (Rey Benayas et al., 2008; Meli et al., 2017).

In some cases, such as forest clearing or when the seed bank has been annihilated by fire, assisted regeneration or recovery is required. In Indonesia, this is commonly carried out by planting tree seedlings mainly of Shorea, Gonystylus and Dyera, in addition to hydrological recovery through rewetting (Giesen \& van der Meer, 2009; van Eijk et al., 2009; Graham et al., 2013; Nurjanah et al., 2013). The above species are selected due to their high economic value and high seedling survival rates (Giesen, 2004; Graham, 2009). Dyera and Shorea are also described as fast-growing taxa (Giesen, 2004; Graham et al., 2013). However, the expectations for success of these attempts are low, supposedly due to a lack of ecological knowledge and attention to socioeconomic factors (Page et al., 2009; van Eijk et al., 2009; Graham et al., 2017).

The success of restoration efforts, particularly broad planting, are thwarted not only by inadequate ecological knowledge and poor understanding of socioeconomic condition, but also by the poor reproductive success of restored populations (Bozzano et al., 2014; Prill, 2016). Therefore, to ensure the long-term success of assisted regeneration, the reproductive patterns of selected taxa must also be considered. For example, Shorea experiences limitations in its early reproductive stages (Section 5.2). Gonystylus does not flower annually and only $20 \%$ of their flowers develop into fruits (Ismail et al., 
2011). It also suffers from high seed predation by squirrels and bats and its seed dispersal and germination rates are low (Ibrahim, 1996). Although Dyera produces enormous amounts of seeds with high germination rates (Sosef et al., 1998), it flowers only once every 4-5 years (Giesen, 2004). Thus, using Shorea, Gonystylus and Dyera for initial planting might not be optimal to accommodate forest regrowth, as such ecosystems will likely continue to require seedling supplies and active plantings.

As the resources for seedling transplantation are often limited, selecting rapidly regenerating taxa for reforestation might improve the efficiency and reduce the cost of restoration efforts. In the Sungai Buluh record, Gnetum, Calophyllum, Ficus and Sapotaceae displayed rapid regeneration, likely due to their high seed productivities, seed viabilities, seed germination rates and seedling survival rates. Those taxa, and/or other peat-swamp taxa that have similar reproductive abilities, are thus more suitable for tree planting on targeted peatlands, particularly as colonisers. The desired taxa, either of conservation or economic interests (e.g. Shorea, Gonystylus and Dyera), can subsequently be transplanted once the forest cover is re-established. Moreover, taxa with high regenerative power can possibly be used in lower-cost alternative restoration efforts such as direct seed sowing (Graham et al., 2013; Saito et al., 2016) or for creating "woodland islets" by planting many small and dense "islands" of trees which later act as seed sources for the surrounding area (Rey Benayas et al., 2008). The savings obtained from these lower-cost alternatives can be allocated towards costly long-term monitoring, aftercare and maintenance, important aspects in restoration that are often neglected (Graham et al., 2017).

In Indonesia, peatland restoration efforts are mostly designated for 60 years (e.g. http://katinganproject.com/explore-katingan; http://www.rekoforest.org/). This 


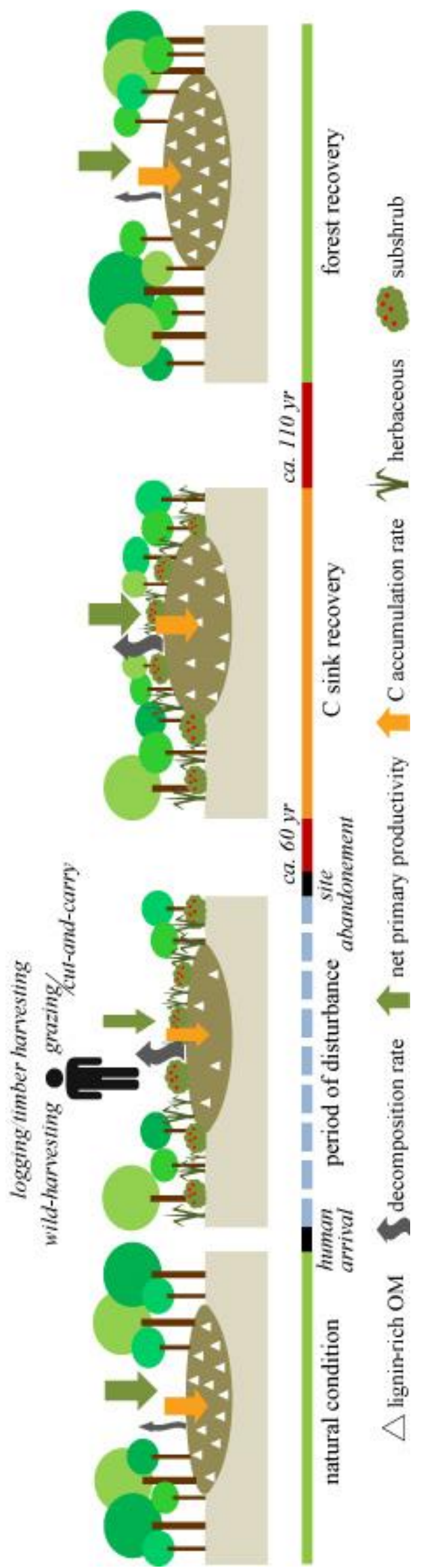

framework follows the 60 -year concession license granted by the Ministry of Forestry, Republic of Indonesia. Each permit granted has the possibility of a one-time extension of 35 years (http://kph.menlhk.go.id/).

In Sungai Buluh, it took 60 years for the $\mathrm{C}$ sequestration function and 170 years for the floristic composition to recover from past human disturbance. Therefore, the current 95-year restoration frames, assuming that the extension is given, are likely insufficient. While this period may be adequate for restoring the $\mathrm{C}$ sink potential, it is insufficient for the restoration of biodiversity values, suggesting that policies aimed at granting longer concession licenses should be considered. Alternatively, concessions could be granted for different validity periods according to the aims and goals of the project, with shorter licenses for projects targeting only $\mathrm{C}$ sequestration enhancement and longer for those targeting full biodiversity recovery. 


\section{Acknowledgements}

We thank Dorothee Dasbach (Chemielabor, ZMT Bremen) for supporting the carbon content measurements as well as Jackson Rodrigues for his help with the statistical analysis. We thank Meyta Pratiwi and Garbayu Tri Handoyo for their help with the preparation of second language abstract. We also thank Christoph Peters and Paula Rodriguez for their interesting perspectives throughout the writing process. The study was conducted using the research permit (232/SIP/FRP/SM/VII/2013) from the Ministry of Research and Technology of Indonesia (RISTEK), the collection permits (3272/IPH.1/KS.02/X/2013 and S.709/KKH-2/2013) recommended by the Indonesian Institute of Sciences (LIPI) and Ministry of Forestry (PHKA) and the export permit (183/IPH.1/KS.02/I/2014) recommended by LIPI. We gratefully acknowledge the logistic support from the EFForTS coordination team and the Indonesian partner universities, Institut Pertanian Bogor (IPB) and University of Jambi (UNJA), the Ministry of Education in Jakarta (DIKTI) and LIPI. We also thank our financial providers the DFG Sonderforschungsbereich in CRC 990 (EFForTS) subproject A01 and Deutsche Akademische Austauschdienst (DAAD). Finally, we expressed our gratitude to the reviewers for their comments and suggestions for improving this manuscript.

\section{Data accessibility}

The data used in the analyses are available at PANGAEA https://pangaea.de/ (Hapsari et al., 2017) 


\section{Authors' contribution}

KAH conceived the ideas, interpreted the data and led the manuscript writing; TCJ substantially contributed to the intellectual content; KAH, SB and HB analysed the data; KAH, SB and PR collected the data; SB and HB obtained the funding. All authors critically contributed to the manuscript draft and gave final approval for publication.

\section{Reference}

Alam, S. (2014) Pre-fourteenth century settlement patterns in the Lower Batanghari, Jambi Province, Sumatra. Proceeding of $7^{\text {th }}$ Ecology, Human Habitat and Environmental Change in the Malay World (19-20 August 2014, Pekanbaru, Riau, Indonesia), 13-21.

Aldrian, E. \& Susanto, R.D. (2003) Identification of three dominant rainfall regions within Indonesia and their relationship to sea surface temperature. International Journal of Climatology, 23, 1435-1452. doi:10.1002/joc.950

Ali, A.I.M., Sandi, S., Muhakka, Riswandi, Budianta, D. (2014) Grazing of Pampangan Buffaloes at Non Tidal Swamp in South Sumatra of Indonesia. APCBEE Procedia, 8, 87-92. doi:10.1016/j.apcbee.2014.03.006

Andaya, B.W. (1993) To Live as Brothers: Southeast Sumatra in the Seventeenth and Eighteenth Centuries. Honolulu, US: University of Hawai i Press.

Andaya, L.Y. (2001) The search for the 'origins' of Melayu. Journal of Southeast Asian Studies, 32(3), 315-330.

Anderson, J.A.R. (1961) The ecology and forest types of the peat swamp forests of Sarawak and Brunei in relation to their siviculture. Dissertation. University of Edinburgh, UK.

Anderson, J.A.R. \& Muller, J. (1975) Palynological study of a Holocene peat and a Miocene coal deposit from NW Borneo. Review of Palaeobotany and Palynology, 19, 291-351. doi:10.1016/0034-6667(75)90049-4

Anshari, G., Kershaw, A.P. \& van der Kaars, S. (2001) A Late Pleistocene and Holocene pollen and charcoal record from peat swamp forest, Lake Sentarum wildlife reserve, West Kalimantan, Indonesia. Palaeogeography, Palaeoclimatology, Palaeoecology, 171, 213-228. doi:10.1016/S0031-0182(01)00246-2

Bastian, O., Haase, D. \& Grunewald, K. (2012) Ecosystem properties, potentials and services - The EPPS conceptual framework and an urban application example. Ecological Indicators, 21, 7-16. doi:10.1016/j.ecolind.2011.03.014

Bhagwat, S.A., Dudley, N. \& Harrop, S.R. (2011) Religious following in biodiversity hotspots: challenges and opportunities for conservation and development. Conservation Letters, 4, 234-240. doi: 10.1111/j.1755-263X.2011.00169.x 
Biagioni, S., Krashevska, V., Achnopha, Y., Saad, A., Sabiham, S. \& Behling, H. (2015) 8000 years of vegetation dynamics and environmental changes of a unique inland peat ecosystem of the Jambi Province in Central Sumatra, Indonesia. Palaeogeography, Palaeoclimatology, Palaeoecology, 440, 813-829. http://dx.doi.org/10.1016/j.palaeo.2015.09.048

Birks, H.J.B. (2012) Ecological palaeoecology and conservation biology : controversies, challenges, and compromises. International Journal of Biodiversity Science,

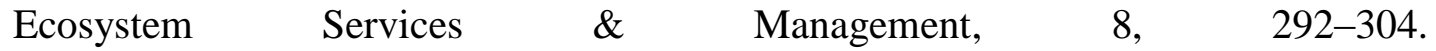
http://dx.doi.org/10.1080/21513732.2012.701667

Boechari (1985) Ritual deposits of Candi Gumpung (Muara Jambi). In SPAFA Final Report, Consultative Workshop on Archaeological and Environmental Studies on Srivijaya, September 16-30, 237-238.

Bozzano, M., Jalonen, R., Thomas, E., Boshier, D., Gallo, L., Cavers, S., Bordács, S., Smith, P. \& Loo, J. (2014) Genetic considerations in ecosystem restoration using native tree species. State of the world's forest genetic resources - Thematic study. Rome, Italy: FAO and Bioversity International.

Bradley, R.S. (1999) Paleoclimatology: Reconstructing Climates of the Quaternary. International Geophysics, 68, 1-614. https://doi.org/10.1016/S0074-6142(99)80011$\underline{4}$

Brady, M.A. (1997) Organic Matter Dynamics of Coastal Peat Deposits in Sumatra, Indonesia. Dissertation. The University of British Columbia, Canada.

BRG - Badan Restorasi Gambut (2016) Mengawali Restorasi Gambut Indonesia. Annual Report. Jakarta, Indonesia: Badan Restorasi Gambut.

Bruijnzeel, L. A., Scatena, F. N. \& Hamilton, L. S. (2010) Tropical Montane Cloud Forests: Science for Conservation and Management. Cambridge, UK: Cambridge University Press.

Bullecer, R.C. \& Bullecer, G.H.C. (2011) Growth response of Bago (Gnetum gnemon) cuttings to various rooting agents. Asian Journal of Biodiversity, 2(1), 172-182. http://dx.doi.org/10.7828/ajob.v2i1.97

Cadiz, R.T. \& Florido, H.B. (2001) Bago (Gnetum gnemon Linn.). Research Information Series on Ecosystem, 13(2). http://erdb.denr.gov.ph/rise/r_v13/r_v13n2.pdf

Carneiro, F., Degen, B., Kanashiro, M., de Lacerda, A.E.B. \& Sebbenn, A.M. (2009) High levels of pollen dispersal detected through paternity analysis from a continuous Symphonia globulifera population in the Brazilian Amazon. Forest Ecology and Management, 258, 1260-1266. doi:10.1016/j.foreco.2009.06.019

Carpenter, S., Walker, B., Anderies, J. \& Abel. N. (2001) From Metaphor to Measurement: Resilience of What to What? Ecosystems, 4(8), 765-781. doi:10.1007/s10021-001-0045-9

Cetl, I. (1960) The Size of Pollen Grain of the Genus Triticum L. Biologia Plantarum (Praha), 2(4), 287-291. 
Chapin III, F.S., Kofinas, G.P. \& Folke, C. (2009) Principles of Ecosystem Stewardship: Resilience-Based Natural Resource Management in a Changing World. New York, USA: Springer.

Chaturvedi, M. \& Datta, K.I. (2001) Pollen morphology in Saccharurn L. (Poaceae)wild and cultivated sugar cane species. Feddes Repertorium, 112(5-6), 387-390.

Chaturvedi, M., Datta, K. \& Nair, P.K.K. (1998) Pollen morphology of Oryza (Poaceae). Grana, 37(2), 79-86. doi:10.1080/00173139809362647

Chazdon, R.L. (2003) Tropical forest recovery: Legacies of human impact and natural disturbances. Perspectives in Plant Ecology Evolution and Systematics, 6, 51-71.

Chazdon, R.L. (2014) Second Growth: The Promise of Tropical Forest Regeneration in an Age of deforestation. Chicago, USA: The University of Chicago Press.

Chazdon, R.L., Letcher, S.G., van Breugel, M., Martínez-Ramos, M., Bongers, F. \& Finegan, B. (2007) Rates of change in tree communities of secondary Neotropical forests following major disturbances. Philosophical Transactions of the Royal Society B, 362, 273-289. doi:10.1098/rstb.2006.1990

Cheplick, G.P. (1998) Population Biology of Grasses. Cambridge, UK: Cambridge University Press.

Chimner, R.A. \& Ewel, K.C. (2005) A tropical freshwater wetland: II. Production, decomposition, and peat formation. Wetlands Ecology and Management, 13, 671684. doi:10.1007/s11273-005-0965-9

Chung, R.C.K. (2006) Revision of Grewia (Malvaceae-Grewioideae) in Peninsular Malaysia and Borneo. Edinburgh Journal of Botany, 62, 1. doi:10.1017/S0960428606000011

Clark, C.J. (2009) Factors that determine patterns of seedling recruitment in an Afrotropical forest. Dissertation. University of Florida, USA.

Clark, D.A., Brown, S., Kicklighter, D.W.J., Chambers, Q., Thomlinson, J.R., Ni, J. \& Holland, E.A. (2001) Net primary production in tropical forests: An evaluation and synthesis of existing field data. Ecology Applications, 11(2), 371-384. doi:10.1890/1051-0761(2001)011[0371:NPPITF]2.0.CO;2

Clark, D.B., Clark, D.A., Brown, S., Oberbauer, S.F. \& Veldkamp, E. (2002) Stocks and flows of coarse woody debris across a tropical rain forest nutrient and topography gradient. Forest Ecology and Management, 164, 237-248.

Cole, L.E.S., Bhagwat, S.A. \& Willis, K.J. (2014) Recovery and resilience of tropical forest after disturbance. Nature Communication, 5, 3906. doi:10.1038/ncomms4906

Cole, L.E.S., Bhagwat, S.A. \& Willis, K.J. (2015) Long-term disturbance dynamics and resilience of tropical peat swamp forests. Journal of Ecology, 103, 16-30. doi:10.1111/1365-2745.12329

Côté, I.M. \& Darling, E.S. (2010) Rethinking Ecosystem Resilience in the Face of Climate Change. PloS Biology, 8(7), e1000438. doi:10.1371/journal.pbio.1000438 
Cottee-Jones, H.E.W., Bajpai, O., Chaudhary, L.B. \& Whittaker, R.J. (2016) The importance of Ficus (Moraceae) trees for tropical forest restoration. BIOTROPICA, 48(3), 413-419. doi:10.1111/btp.12304

Damanik, J. (1974) Jalannya hukum adat Simalungun: gorga tapak Raja Suleman, habonaran do bona. Pematang Siantar, Sumatra: P.D. Aslan.

Dargie, G.C., Lewis, S.L., Lawson, I.T., Mitchard, E.T.A., Page, S.E., Bocko, Y.E. \& Ifo, S.A. (2017) Age, extent and carbon storage of the central Congo Basin peatland complex. Nature, 542, 86-90. doi:10.1038/nature21048

Denslow, J.S. \& Guzman, S. (2000) Variation in stand structure, light and seedling abundance across a tropical moist forest chronosequence, Panama. Journal of Vegetation Science, 11, 201-212. doi: 10.2307/3236800

Dickson, C. (1988) Distinguishing cereal from wild grass pollen: some limitation. Circaea, 5(2), 67-71.

Dobson, A.P., Bradshaw, A.D. \& Baker, A.J.M. (1997) Hopes for the future: Restoration ecology and conservation biology. Science, 277, 515-522.

Dolan, L.C., Matulka, R.A. \& Burdock, G.A. (2010) Naturally Occurring Food Toxins. Toxins, 2, 2289-2332. doi:10.3390/toxins2092289

Dommain, R., Cobb, A.R., Joosten, H., Glaser, P., Chua, A., Gandois, L., .. \& Harvey, C. (2015) Forest dynamic and tip-up pools drive pulses of high carbon accumulation rates in a tropical peat dome in Borneo (Southeast Asia). Journal of Geophysical Research: Biogeosciences, 120, 617-640. doi:10.1002/2014JG002796

Faegri, K. \& Iversen, J. (1989) In Faegri, K., Kaland, P.E., Krzywinski, K. (Eds.), Textbook of Pollen Analysis. New York, USA: John Wiley.

Feshe, J., Hofstedea, R., Aguirrea, N., Paladinesa, C., Kooijmanb, A. \& Sevinka, J. (2002) High altitude tropical secondary forests: a competitive carbon sink? Forest Ecology and Management, 163, 9-25.

Flenley, J.R. \& Butler, K. (2001) Evidence for continued disturbance of upland rain forest in Sumatra fro the last 7000 years of an 11000 year record. Palaeogeography, Palaeoclimatology, Palaeoecology, 171, 289-305. doi: 0.1016/S00310182(01)00250-4

Finegan, B. (1996) Pattern and process in Neotropical secondary rain forests: the first 100 years of succession. Tree, 11(3), 119-124.

Friday, J.B. \& Okano, D. (2006) Calophyllum inophyllum (kamani), ver.2.1. In Elevitch, C.R. (Ed.), Species Profile from Pacific Island Agroforestry. pp. 1-17 http://www.traditionaltree. org. Holualoa, USA: Permanent Agricultural Resources (PAR).

Gautam, T.P. \& Mandal, T.N. (2016) Effect of disturbance on biomass, production and carbon dynamics in moist tropical forest of eastern Nepal. Forest Ecosystems, 3, 11. doi: 10.1186/s40663-016-0070-y 
GBRMPA - Great Barrier Reef Marine Park Authority (2009) In brief: Great Barrier Reef outlook report 2009. Queensland, Australia: GBRMPA.

Gerber, L. (2010) Conservation Biology. Nature Education Knowledge, 3(10), 14.

Ghazoul, J., Liston, K.A. \& Boyle, T.J.B. (1998) Disturbance induced density dependent seed set in Shorea siamensis (Dipterocarpaceae), a tropical forest tree. Journal of Ecology, 86, 462-473.

Ghazoul, J. (2005) Pollen and seed dispersal among dispersed plants. Biological Reviews, 80, 413-443. doi:10.1017/S1464793105006731

Ghazoul, J. (2016) Dipterocarp biology, ecology, and conservation. New York, USA: Oxford University Press.

Giesen, W. (2004) Cause of peat-swamp forest degradation in Berbak NP, Indonesia, and recommendations for restoration. Arnhem, the Netherland: ARCADIS Euroconsult.

Giesen, W. \& van der Meer, P. (2009) Guidelines for the rehabilitation of degraded peat swamp forests in Central Kalimantan: Master plan for the conservation and development of the ex-mega rice project area in Central Kalimantan. Arnhem, the Netherland: Euroconsult Mott MacDonald.

Gorenflo, L.J. \& Brandon, K. (2006) Key human dimensions of gaps in global biodiversity conservation. BioScience, 56, 723-31. https://doi.org/10.1641/00063568(2006)56[723:KHDOGI]2.0.CO;2

Graham, L.L.B. (2009) A literature review of the ecology and silviculture of tropical peat swamp forest tree species found naturally occurring in Central Kalimantan. Technical Report. Jakarta, Indonesia: The Kalimantan Forests and Climate Partnership. doi:10.13140/RG.2.1.2120.4882

Graham, L.L.B., Giesen, W. \& Page, S.E. (2017) A common-sense approach to tropical peat swamp forest restoration in Southeast Asia. Restoration Ecology, 25(2), 312321. doi:10.1111/rec. 12465

Graham, L.L.B., Turjaman, M. \& Page, S.E. (2013) Shorea balangeran and Dyera polyphylla (syn. Dyera lowii) as tropical peat swamp forest restoration transplant species: effects of mycorrhizae and level of disturbance. Wetlands Ecology and Management, 21, 307-321. doi:10.1007/s11273-013-9302-x

Guariguata, M.R. \& Ostertag, R. (2001) Neotropical secondary forest succession: changes in structural and functional characteristic. Forest Ecology and Management, 148(1-3), 185-206. http://dx.doi.org/10.1016/S0378-1127(00)00535-1

Gunawan, H., Page, S.E., Muhammad, A., Qomar, N., Helentina, T., Hakim, A., ... \& Darmasanti, P. (2007) Peat swamp forest regeneration using green belts in a timber estate in Riau, Sumatra Indonesia. In Rieley, J.O., Banks, C.J., Radjagukguk, B. (Eds.), Carbon-Climate-Human Interactions on Tropical Peatland: Carbon Pools, Fire, Mitigation, Restoration and Wise Use (pp. 83-88) Proceedings of the International Symposium and Workshop on Tropical Peatland, Yogyakarta, Indonesia, 27-29 August 2007. 
Gunawan, H., Kobayashi, S., Mizuno, K. \& Kono, Y. (2012) Peat swamp forest types and their regeneration in Giam Siak Kecil-Bukit Batu Biosphere Reserve, Riau, East Sumatra, Indonesia. Mires and Peat, 10(5), 1-17.

Gunderson, L.H. (2000) Ecological resilience - In theory and application. Annual Review of Ecology and Systematics, 31, 425-439. https://doi.org/10.1146/annurev.ecolsys.31.1.425

Hapsari, KA., Biagioni, S., Jennerjahn, T., Reimer, P.M., Saad, A., Sabiham, S. \& Behling, H. (2017) Environmental dynamics and carbon accumulation rate of a tropical peatland in Central Sumatra, Indonesia. Quaternary Science Reviews, 169, 173-187. doi:10.1016/j.quascirev.2017.05.026

Higuera, P.E., Brubaker, L.B., Anderson, P.M., Hu, F.S. \& Brown, T.A. (2009) Vegetation mediated the impacts of postglacial climatic change on fire regimes in the south-central Brooks Range, Alaska. Ecological Monogrraphs, 79, 201-219. doi:10.1890/07-2019.1

Hirth, F. \& Rockhill, W.W. (1966) Chau Ju-Kuo on the Chinese and Arab Trade. Amsterdam, Netherland: Oriental Press.

Hjelle, K.L., Mehl, I.K. Sugita, S. \& Andersen. G.L. (2015) From pollen percentage to vegetation cover: evaluation of the Landscape Reconstruction Algorithm in western Norway. Journal of Quaternary Science, 30(4), 312-324. doi:10.1002/jqs.2769

Holl, K.D. (2017) Restoring tropical forests from the bottom up. Science, 355, 455-456. doi:10.1126/science.aam5432

Holling, C.S. (1973) Resilience and stability of ecological system. Annual Review of Ecology and Systematics, 4, 1-23

Holling, C.S. (1996) Engineering resilience versus ecological resilience. In Schulze, P. (Ed.), Engineering within ecological constraints. Washington, D.C., USA: National Academy.

Hoogerwerf, A. (1970). Udjung Kulon: The Land of the Last Javan Rhinoceros. E.J. Brill, Leiden.

Hope, G., Chokkalingam, U. \& Anwar, S. (2005) The stratigraphy and fire history of the Kutai Peatlands, Kalimantan, Indonesia. Quaternary Research, 64, 407-417. doi:10.1016/j.yqres.2005.08.009

Howe, H.F. (2016) Making dispersal syndromes and networks useful in tropical conservation and restoration. Global Ecology and Conservation, 6, 152-178. https://doi.org/10.1016/j.gecco.2016.03.002

Humphreys, L.R. (1991) Tropical pasture utilisation. Sidney, Australia: Cambridge University Press.

Hunt, C.O. \& Premathilake, R. (2012) Early Holocene vegetation, human activity and climate from Sarawak, Malaysian Borneo. Quaternary International, 249, 105-119. doi:10.1016/j.jas.2007.02.023 
Ibrahim, S. (1996) Gonystylus bancanus: some observation on its flowering, fruiting, seed predation and germination. Journal of Tropical forest Science, 8(3), 424-426.

Islebe, G.A., Hooghiemstra, H., Brenner, M., Curtis, J.H. \& Hodell, D.A. (1996) A Holocene vegetation history from lowland Guatemala. The Holocene, 6(3), 265-271.

Ismail, P., Nizam, M.S., Latiff, A., Hanum, I.F. \& Shamsudin, I. (2011) Phenology of Gonystylus bancanus in Pahang, Peninsular Malaysia. Journal of Tropical Forest Science, 23(2), 143-151.

Johnsingh, A.J.T. (2004) On Jim Corbett's trail and other tales from tree-tops. New Delhi, India: Permanent Black.

Jones, S.E. \& Pearce, K.G. (2015) A pollen morphology study from the Kelabit Highlands of Sarawak, Malaysian Borneo. Palynology, 39, 150-204. doi:10.1080/01916122.2014.940472

Juggins, S. (2007) C2 user guide: Software for ecological and palaeoecological data analysis and visualization. University of Newcastle, UK.

Kobayashi, S. (2000) Initial phase of secondary succession in the exploited peat swamp forest (Shorea albida) at Sungei Damit, Belait in Brunei Darussalam. In T. Iwakuma et al. (Eds.), Proceedings of the International Symposium on Tropical Peatlands (pp. 205-214), Bogor, Indonesia, 22-23 November 1999. Hokkaido University and Indonesian Institute of Science.

Köhler, E. \& Lange, E. (1979) A contribution to distinguishing cereal from wild grass pollen grains by LM and SEM. Grana, 18(3), 133-140. doi:10.1080/00173137909424973

Koop, A.L. (2004) Differential seed mortality among habitats limits the distribution of the invasive non-native shrub Ardisia elliptica. Plant Ecology, 172, 237-249.

Kozok, U. \& van Reijn, E. (2010) Ādityawarman: three inscriptions of the Sumatran 'King of all supreme kings'. Indonesia and the Malay World, 38(110), 135-15. doi: $10.1080 / 13639811003665488$

Kuaraksa, C. \& Elliott, S. (2013) The Use of Asian Ficus Species for Restoring Tropical Forest Ecosystems. Restoration Ecology, 21(1), 86-95. doi: 10.1111/j.1526100X.2011.00853.x

Kumar, C.N.P., Somashekar, R.K., Nagaraja, B.C., Ramachandra, K. \& Shivaprasad, D. (2015) Seed bank estimation and regeneration studies of Calophyllum apetalum Willd., from Western Ghats of Karnataka. Proceedings of the International Academy of Ecology and Environmental Sciences, 5(3), 97-103.

Lake, P.S. (2013) Resistance, resilience and restoration. Ecological Management and Restoration,14(1), 20-24. doi:10.1111/emr.12016

Laurila-Pant, M., Lehikoinen, A., Uusilato, L. \& Venerjärvi, R. (2015) How to value biodiversity in environmental management? Ecological Indicators, 55, 1-11. http://dx.doi.org/10.1016/j.ecolind.2015.02.034 
Lemmens, R.H.M.J., Soerianegara, I. \& Wong, W.C. (1995) Plant Resources of SouthEast Asia No. 5(2). Timber trees: Minor commercial timbers. Bogor, Indonesia: Prosea Foundation.

Leslie, P. \& McCabe, T. (2013) Response Diversity and Resilience in Social-Ecological Systems. Current Anthropology, 54(2), 114-143.

Letcher, S.G. \& Chazdon, R.L. (2009) Rapid recovery of biomass, species richness, and species composition in a forest chronosequence in northeastern Costa Rica. BIOTROPICA, 41(5), 608-617. doi:10.1111/j.1744-7429.2009.00517.x

Lim, T.K. (2012) Edible Medicinal And Non-Medicinal Plants: Volume 4, Fruits. Dordrecht, the Netherland: Springer.

Liu, W.H., Bryant, D.M., Hutyra, L.R., Saleska, S.R., Hammond-Pyle, E., Curran, D. \& Wofsy, S.C. (2006) Woody debris contribution to the carbon budget of selectively logged and maturing mid-latitude forests. Oecologia, 148, 108-117. http://dx.doi.org/10.1007/s00442-006-0356-9

Manner, H.I. \& Elevitch, C.R. (2006) Gnetum gnemon (gnemon), ver. 1.1. In: Elevitch, C.R. Species profiles for Pacific Island Agroforestry. Holualoa, USA: Permanent Agriculture Resources (PAR). http://www.traditionaltree.org

Martin, P.A., Newton, A.C. \& Bullock, J.M. (2013) Carbon pools recover more quickly than plant biodiversity in tropical secondary forests. Proceedings of the Royal Society B, 280, 20140303. http://dx.doi.org/10.1098/rspb.2013.2236

Masuda, S., Tani, N., Ueno, S., Lee, S.L., Muhammad, N., Kondo, T., ... \& Tsumura, Y. (2013) Non-density dependent pollen dispersal of Shorea maxwelliana (Dipterocarpaceae) revealed by a Bayesian Mating Model based on paternity analysis in two synchronized flowering seasons. PLoS ONE, 8(12), e82039. doi:10.1371/journal.pone.0082039

McKinnon, E.E. (1985) Early polities in Southern Sumatra: some preliminary observations based on archaeological evidence. Indonesia, 40, 1-36.

Melati, D.N., Jaya, I.N.S., Pérez-Cruzado, C., Zuhdi, M., Fehrmann, L., Magdon, P. \& Kleinn, C. (2015) Spatio-temporal analysis on land transformation in a forested tropical landscape in Jambi Province, Sumatra. Conference presentation of European Geosciences Union General Assembly 17 April 2015. Vienna, Austria.

Meli, P., Holl, K.D., Rey Benayas, J.M., Jones, H.P., Jones, P.C., Montoya, D. \& Mateos, D.M. (2017) A global review of past land use, climate, and active vs. passive restoration effects on forest recovery. PLoS ONE, 12(2), e0171368. doi:10.1371/journal.pone. 0171368

Miettinen, J., Hooijer, A., Tollenaar, D., Page, S.E., Malins, C., Vernimmen, R., ... \& Liew, S.C. (2012) Extent of industrial plantations on Southeast Asian peatlands in 2010 with analysis of historical expansion and future projections. Global Change Biology and Bioenergy, 4, 908-18.

Miller, J.R. \& Hobbs, R.J. (2002) Conservation where people live and work. Conservation Biology, 16, 330-337. 
Mizuno, K., Fujita, M.S. \& Kawai, S. (2016) Catastrophe and regeneration in Indonesia's peatlands: ecology, economy and society. Kyoto, Japan: National University of Singapore Press in association with Kyoto University Press.

Muhumuza, M. \& Balkwill, K. (2013) Factors Affecting the Success of Conserving Biodiversity in National Parks: A Review of Case Studies from Africa. International Journal of Biodiversity, 2013(1), ID 798101. http://dx.doi.org/10.1155/2013/798101

Mulyana, A., Moeliono, M., Minnigh, P., Indriatmoko, Y., Limberg, G., Utomo, N.A., ... \& Hamzah (2010) Establishing special use zones in national parks: can it break the conservation deadlock in Indonesia? Brief 1. Bogor, Indonesia: Center for International Forestry Research (CIFOR).

Mumby, P., Chollett, I., Bozec, Y. \& Wolff, N.H. (2014) Ecological resilience, robustness and vulnerability: how do these concepts benefit ecosystem management? Current Opinion in Environmental Sustainability, 7, 22-27. http://dx.doi.org/10.1016/j.cosust.2013.11.021

Murali, K.S., Shankar, U., Shaanker, U., Ganeshaiah, K.N. \& Bawa, K.S. (1996) Extraction of non-timber forest products in the forest of Biligiri Rangan Hills, India. 2. Impact of NTFP extraction on regeneration, population structure and species composition. Economic Botany, 50(3), 252-269.

Navroodi, I.H. (2015) Effects of livestock exclusion on forest tree regeneration (Case study: Ramsar district 1- Iran). Journal of Forest Science, 61(1), 1-6. doi:10.17221/30/2014-JFS

Newton, A.C. \& Tejedor, N. (2011) Principles and practice of forest landscape restoration: case studies from the drylands of Latin America. Gland, Switzerland: IUCN.

Nurjanah, S., Octavia, D. \& Kusumadewi, F. (2013) Identifikasi lokasi penanaman kembali ramin (Gonystilus bancanus Kurz) di hutan rawa gambut Sumatra dan Kalimantan. Bogor, Indonesia: Pusat Penelitian dan Pengembangan Konservasi dan Rehabilitasi with International Tropical Timber Organization (ITTO)-CITES Phase 2 Project.

Ong, H.C. (2004) Tumbuhan Liar: Khasiat Ubatan dan Kegunaan Lain. Kuala Lumpur, Malaysia: Utusan Publication and Distribution Sdn. Bhd.

Padmanaba, M. \& Sheil, D. (2014) Spread of the invasive alien species Piper aduncum via logging roads in Borneo. Tropical Conservation Science, 7, 35-44.

Page, S.E. \& Baird, A.J. (2016) Peatlands and global change: response and resilience. Annual Reviews of Environment and Resource, 41, 35-57. doi: 10.1146/annurevenviron-110615-085520

Page, S.E., Hoscilo, A., Wösten, H., Jauhiainen, J., Silvius, M., Rieley, J., ... \& Limin, S. (2009) Restoration ecology of lowland tropical peatlands in Southeast Asia: current knowledge and future research directions. Ecosystems, 12, 888-905. doi: $10.1007 / \mathrm{s} 10021-008-9216-2$

Page, S.E., Rieley, J.O. \& Banks, C.J. (2011) Global and regional importance of the 
tropical peatland carbon pool. Global Change Biology, 17, 798-818. doi:10.1111/j.1365-2486.2010.02279.x

Page, J.S. (1978) A scanning electron microscope survey of grass pollen. Kew Bulletin, 32(2), 313-319.

Petrenko, C., Paltseva, J. \& Searle, S. (2016). Ecological impacts of palm oil expansion in Indonesia. Washington, USA: International Council on Clean Transportation.

Poerbatjaraka, R.M.Ng. (1952) Kapustakaan Djawi (1 ${ }^{\text {st }}$ ed.). Jakarta, Indonesia: Djambatan.

Posa, M.R.C., Wijedasa, L.S. \& Corlett, R.T. (2011) Biodiversity and Conservation of Tropical Peat Swamp Forests. BioScience, 61, 49-57. doi:10.1525/bio.2011.61.1.10

Prill, L. (2016) Planting trees to provide local wood resources and restore degraded dry tropical forests - Principles, challenges and research needs. Hamburg, Germany: SuLaMa - Participatory research to support sustainable land management on the Mahalafy Plateau in south-western Madagarcar, University of Hamburg.

Quattrocchi, F.L.S.U. (2012) CRC world dictionary of medicinal and poisonous plants: Common names, scientific names, eponyms, synonyms and etymology. Boca Raton, USA: CRC press, Taylor and Francis.

R Core Team. (2014) R: A language and environment for statistical computing. R Foundation for Statistical Computing, Vienna, Austria. http://www.R-project.org/.

Rahman, N.H.S.B.N.A. (1993). Pre-modern cities in the Malay Peninsula and Sumatra. Jurnal Arkeologi Malaysia, 6, 63-77

Ramutsindela, M. (2014) Cartographies of Nature: How Nature Conservation Animates Borders. Newcastle, UK: Cambridge Scholar Publishing.

Rey Benayas, J.M., Bullock, J.M. \& Newton, A.C. (2008) Creating woodland islets to reconcile ecological restoration, conservation, and agricultural land use. Frontiers in Ecology and the Environment, 6(6), 329-336, doi:10.1890/070057

Rhodes, A.N. (1998) A method for the preparation and quantification of microscopic charcoal from terrestrial and lacustrine sediment cores. The Holocene, 8, 113-117. doi:10.1191/095968398671104653

Rieley, J.O. (2007) Tropical peatland - The amazing dual ecosystem: coexistence and mutual benefit. In Rieley, J.O., Banks, C.J., Ragkagukguk, B. (Eds.), Proceedings of the international symposium and workshop on tropical peatland (pp. 1-14) Yogyakarta, Indonesia: EU CARBOPEAT and RESTORPEAT Partnership, GadjahMada University, Indonesia and University of Leicester, United Kingdom.

Saito, H., Koizumi, A., Gaman, S., Yuda, P., Penyang \& Shibuya, M. (2016) Tropical peatland forestry: Toward forest restoration and sustainable use of wood resources in degraded peatland. In Osaki, M. \& Tsuji, N. (Eds.) Tropical peatland ecosystems (pp. 513-549). Tokyo, Japan: Springer.

Saji, N.H., Goswami, B.N., Vinayachandran, P.N. \& Yamagata, T. (1999) A dipole mode in the tropical Indian Ocean. Nature, 401, 360-3. doi:10.1038/43854 
Saldarriaga, J.G., West, D.C., Tharp, M.L. \& Uhl, C. (1988) Long-Term chronosequence of forest succession in the upper Rio Negro of Colombia and Venezuela. Journal of Ecology, 76(4), 938-958.

SER - Society for Ecological Restoration (2004) Society for ecological restoration international science $\&$ policy working group $\left(2^{\text {nd }}\right.$ ed.). The SER International Primer on Ecological Restoration (http://www.ser.org) \& Tucson: Society for Ecological Restoration International

Setianah, R., Jayadi, S. \& Herman, R. (2004) Eating behavior of local goat cross pasturing in peatland: a case study in Kalampangan, Palangkaraya, Central Kalimantan. Media Peternakan, 27, 111-122.

Silver, W.L. \& Miya, R.K. (2001) Global patterns in root decomposition: comparisons of climate and litter quality effects. Oecologia, 129, 407-419. https://doi.org/10.1007/s004420100740

Sjögersten, S., Black, C.R., Evers, S., Hoyos-Santillan, J., Wright, E.L. \& Turner, B.L. (2014) Tropical wetlands: A missing link in the global carbon cycle? Global Biogeochemical Cycles, 28(12),1371-1386. doi:10.1002/2014GB004844

Skvarla, J.J. \& Larson, D.A. (1966) Fine structural studies of Zea mays pollen I: cell membranes and exine ontogeny. American Journal of Botany, 53(10), 1112-1125.

Soerianegara, I. \& Lemmens, R.H.M.J. (1994) Plant Resources of South-East Asia No. 5(1). Timber trees: Major commercial timbers. Bogor, Indonesia: Prosea Foundation.

Sosef, M.S.M, Hong, L.T. \& Prawirohatmodjo, S. (1998) Plant Resources of South-East Asia No. 5(3). Timber trees: Lesser-known timbers. Bogor, Indonesia: Prosea Foundation.

Sörlin, S. \& Warde, P. (2009) Nature's end: history and the environment. Basingstoke, UK: Palgrave Macmillan.

Stevenson, J. \& Haberle, S. (2005) Macro Charcoal Analysis: A modified technique used by the Department of Archaeology and Natural History. Canberra, Australia. Australian National University (ANU).

Sundari, R. (2005) Conservation and suitable use of peat swamp forests by local communities in South East Asia. Suoseura-Finnish Peatland Society, 56(1), 27-38.

Tambarussi, E.V., Boshier, D., Vencovsky, R., Freitas, M.L.M. \& Sebbenn. A.M. (2017) Inbreeding depression from selfing and mating between relatives in the Neotropical tree Cariniana legalis Mart. Kuntze. Conservation Genetics, 18, 225-234. doi:10.1007/s10592-016-0896-4

Tata, H.L., van Noordwidjk, M., Jasnari \& Widayati, A. (2016) Domestication of Dyera polyphylla (Miq.) Steenis in peatland agroforestry systems in Jambi, Indonesia. Agroforest System, 90, 617-630. doi:10.1007/s10457-015-9837-3

Tjoa-Bonatz, M.L., Neidel, J.D. \& Widiatmoko, A. (2009) Early architectural images from Muara Jambi on Sumatra, Indonesia. Asian Perspectives, 48, 32-55. doi:10.1353/asi.0.0009 
Tolonen, K. \& Turunen, J. (1996) Accumulation rates of carbon in mires in Finland and implications for climate change. The Holocene, 6(2), 171-178.

van Beukering, P., Schaafsma, M., Davies, O. \& Oskolokaite, I. (2008) The economic value of peatland resources within the Central Kalimantan Peatland Project in Indonesia: Perceptions of local communities. Central Kalimantan Peatlands Project (CKPP) Report. Amsterdam, the Netherland. Institute for Environmental Studies, Vrije Universiteit.

van Eijk, P., Leenman, P., Wibisono, I.T.C. \& Giesen, W. (2009) Regeneration and restoration of degraded peat swamp forest in Berbak National Park, Jambi, Sumatra, Indonesia. Malayan Nature Journal, 61(3), 223 - 241.

Wibisono, I.T.C. \& Gandrung, A.Y. (2008) Ujicoba penanaman beberapa jenis tanaman asli hutan rawa gambut pada beberapa lokasi di lahan gambut terdegradasi. Report. Central Kalimantan Peatlands Project

Wijedasa, L.S., Jauhiainen, J., Könönen, M., Lampela, M., Vasander, H., Leblanc, M., ... \& Andersen, R. (2017) Denial of long-term issues with agriculture on tropical peatlands will have devastating consequences. Global Change Biology, 23, 977-982. doi: $10.1111 / \mathrm{gcb} .13516$

Williams, J.W. \& Jackson, S.T. (2003) Palynological and AVHRR observations of modern vegetational gradients in eastern North America. The Holocene, 13(4), 485497.

Witrianto (2014) Potensi sejarah dan purbakala DAS Batanghari. Analisis Sejarah, 5, $68-79$.

Wolters, O.W. (1986) Restudying Some Chinese Writings on Sriwijaya. Indonesia, 42, $1-41$.

Wösten, J.H.M., Rieley, J. \& Page, S.E. (2008) Restoration of Tropical Ecosystems. Alterra - Wageningen University and Research Centre, and the EU INCO RESTORPEAT Partnership. ISBN: 978-90-327-0361-5.

Yule, C.M. (2010) Loss of biodiversity and ecosystem functioning in Indo-Malayan peat swamp forests. Biodiversity and Conservation, 19, 393-409. doi:10.1007/s10531-008-9510-5

Yulianto, E., Rahardjo, A.T., Noeradi, D., Siregar, D.A. \& Hirakawa, K. (2005) A Holocene pollen record of vegetation and coastal environmental changes in the coastal swamp forest at Batulicin, South Kalimantan, Indonesia. Journal of Asian Earth Sciences, 25(1), 1-8. doi:10.1016/j.jseaes.2004.01.005 


\section{Suplementary 1}

Detailed methodology

Detailed methodology provided is a reproduction from Hapsari et al., 2017.

\subsection{Core sampling}

Using a Russian Corer (Jowsey, 1966), the SB-B core (1¹4'10” S, 103³7’12” E; $18 \mathrm{~m}$ asl) was recovered from the Sungai Buluh peat restoration area in 2013. The SB-B core consists of layers of organic matter (OM; from $240 \mathrm{~cm}$ to the top of the core) and underlying mineral clay $(350$ to $240 \mathrm{~cm}$ ). Following the SE-Asian peat classification system (Esterle \& Ferm, 1994; Wüst et al., 2003), the SB-B peat core was also classified into coarse and fine peat in accordance to the size of the fragments and the availability of woody material. An inserted clayey-peat layer was observed in the depth of 200 to $165 \mathrm{~cm}$ (see main text Fig. 3.3. Pollen diagram-core chronology).

\subsection{Radiocarbon chronology}

Eight samples of the peat core were selected for radiocarbon dating. The age-depth model of the SB-B core (see main text Fig. 3.2. Age depth model) was constructed using the Bayesian accumulation model, Bacon script (Blaauw \& Christen, 2011) in R (R Core Team, 2014). The SHCal13 calibration curve was used here. Two samples (at depth 55 and $167 \mathrm{~cm}$ ) were identified as outliers using a robust Student's T method (Christen \& Pérez, 2009) which may have been part of a root that intruded into the deeper layers. 


\subsection{Palynological analysis}

A total of 35 subsamples (subsampling depth is presented in Table S1.1 below) were processed following standard pollen extraction methods (Faegri \& Iversen, 1989). Two tablets of exotic marker Lycopodium spores were added to each subsample prior to the extraction. Pollen and spores were identified using the reference collection of pollen and spores available at the Department of Palynology and Climate Dynamics, University of Göttingen, and other available literatures (see main text Section 3. Material and methods). The pollen and spore grains were counted up to a sum of 300 pollen grains.

Table S1.1. Subsampling depth for pollen analysis

\begin{tabular}{|c|c|c|}
\hline $\begin{array}{c}\text { Sample } \\
\text { no. }\end{array}$ & $\begin{array}{c}\text { Depth } \\
(\mathrm{cm})\end{array}$ & $\begin{array}{c}\text { Age } \\
\text { (cal yr BP) }\end{array}$ \\
\hline 1 & 5 & -25 \\
\hline 2 & 15 & 58 \\
\hline 3 & 25 & 140 \\
\hline 4 & 35 & 223 \\
\hline 5 & 40 & 264 \\
\hline 6 & 45 & 304 \\
\hline 7 & 50 & 344 \\
\hline 8 & 55 & 384 \\
\hline 9 & 60 & 429 \\
\hline 10 & 65 & 475 \\
\hline 11 & 70 & 520 \\
\hline 12 & 75 & 567 \\
\hline 13 & 80 & 632 \\
\hline 14 & 85 & 698 \\
\hline 15 & 90 & 764 \\
\hline 16 & 95 & 829 \\
\hline 17 & 100 & 896 \\
\hline 18 & 105 & 963 \\
\hline
\end{tabular}

\begin{tabular}{|c|c|c|}
\hline $\begin{array}{c}\text { Sample } \\
\text { no. }\end{array}$ & $\begin{array}{c}\text { Depth } \\
(\mathrm{cm})\end{array}$ & $\begin{array}{c}\text { Age } \\
(\text { cal yr BP })\end{array}$ \\
\hline 19 & 110 & 1029 \\
\hline 20 & 115 & 1094 \\
\hline 21 & 120 & 1162 \\
\hline 22 & 125 & 1237 \\
\hline 23 & 135 & 1560 \\
\hline 24 & 145 & 1892 \\
\hline 25 & 155 & 2216 \\
\hline 26 & 165 & 2541 \\
\hline 27 & 175 & 2827 \\
\hline 28 & 185 & 3309 \\
\hline 29 & 190 & 5165 \\
\hline 30 & 195 & 6991 \\
\hline 31 & 205 & 9821 \\
\hline 32 & 210 & 10364 \\
\hline 33 & 215 & 10882 \\
\hline 34 & 225 & 11959 \\
\hline 35 & 235 & 13012 \\
\hline
\end{tabular}




\subsection{Carbon accumulation rate}

Peat bulk density $\left(\mathrm{g} \mathrm{m}^{-2}\right)$ was measured by taking 92 subsamples along the core at 2.5 cm intervals (exception: a $5 \mathrm{~cm}$ interval was applied between depths of $185 \mathrm{~cm}$ and 200 $\mathrm{cm}$ due to insufficient amount of material) and dried overnight at $105^{\circ} \mathrm{C}$ (Chambers et al., 2011). Duplications for peat bulk density quantification were performed on 16 of the 92 samples. Organic carbon $\left(\mathrm{C}_{\text {org }}\right)$ content was measured by taking 92 additional subsamples at the same depths that were subsequently dried at $60^{\circ} \mathrm{C}$ for $48 \mathrm{~h}$, finely ground, and weighed ( 1-1.5 mg). Subsamples were then treated with $1 \mathrm{~N} \mathrm{HCl}$ prior to $\mathrm{C}_{\text {org }}$ determination in order to remove carbonates. $\mathrm{C}_{\text {org }}$ content was determined using high temperature oxidation in a Euro EA3000 elemental analyser. The C accumulation rate $\left(\mathrm{g} \mathrm{C} \mathrm{m}^{-2} \mathrm{yr}^{-1}\right)$ was calculated following the equation used by Tolonen \& Turunen (1996; see main text Section 3. Material and methods).

\subsection{Macro-charcoal analysis}

Subsamples were taken continuously along the core at $0.5 \mathrm{~cm}$ intervals from the depths of $240-180 \mathrm{~cm}$ and at $1 \mathrm{~cm}$ intervals from $180-0 \mathrm{~cm}$. A higher subsample resolution was applied to the lower part of the core due to its lower accumulation rate. Each subsample was washed with weak hydrogen peroxide $\left(6 \% \mathrm{H}_{2} \mathrm{O}_{2}\right)$ to remove organic matter in the sediment and gently wet-sieved (Rhodes, 1998; Stevenson \& Haberle, 2005). Particles $>125 \mu \mathrm{m}$ were retained and charcoal particles $>150 \mu \mathrm{m}$ were counted under a stereomicroscope. Charcoal concentrations were calculated as particles $\mathrm{cm}^{-3}$.

The CharAnalysis program (Higuera et al., 2009) was used to identify the fire regime of the Sungai Buluh peatland. The raw charcoal data were interpolated into 32-yr median temporal resolution and transformed into charcoal accumulation rates (particle $\mathrm{cm}^{-2} \mathrm{yr}^{-1}$ ). 
The charcoal accumulation rates were subsequently separated into a background (low frequency; related to regional charcoal production) and peak (high frequency; related to local fire episodes) components by applying a 1,000-yr window locally weighted regression that is robust to outliers. Using a locally defined Gaussian mixture model (Gavin et al., 2006; Higuera et al., 2008), the noise results from distant fires, redeposition, or analytical error were removed and the peak component $\left(\mathrm{C}_{\text {peak }}\right)$ was defined as residual. Only the peaks exceeding the $99^{\text {th }}$ percentile threshold of the noise distribution were identified as fire peaks which were subsequently subjected to a "Poisson minimum count" to reduce the counting variance bias. Fire frequencies were calculated based on the frequency of fire peaks per 1,000 yr.

\section{Reference}

Blaauw, M. \& Christen, J.A. (2011) Flexible paleoclimate age-depth models using an autoregressive gamma process. Bayesian Analysis, 6, 457-474.

Chambers, F.M., Beilman, D.W. \& Yu, Z. (2011) Methods for determining peat humification and for quantifying peat bulk density, organic matter and carbon content for palaeostudies of climate and peatland carbon dynamics. Mires and Peat, $7,1-10$.

Christen, J.A. \& Pérez, S. (2009) A new robust statistical model for radiocabron data. Radiocarbon, 51(3), 1047-1059.

Esterle, J.S. \& Ferm, J.C. (1994) Spatial variability in modern tropical peat deposition from Sarawak, Malaysia and Sumatra, Indonesia: analogues for coal. International Journal of Coal Geology, 26, 1-41. Doi:10.1016/0166-5162(94)90030-2

Faegri, K. \& Iversen, J. (1989) In Faegri, K., Kaland, P.E., Krzywinski, K. (Eds.), Textbook of Pollen Analysis. New York, USA: John Wiley.

Gavin, D.G., Feng, S.H., Lertzman, K. \& Corbett, P. (2006) Weak climatic control of stand-scale fire history during the late Holocene. Ecology, 87, 1722-1732. doi:10.1890/0012-9658(2006)87[1722:WCCOSF]2.0.CO;2

Hapsari, KA., Biagioni, S., Jennerjahn, T., Reimer, P.M., Saad, A., Sabiham, S. \& Behling, H. (2017) Environmental dynamics and carbon accumulation rate of a tropical peatland in Central Sumatra, Indonesia. Quaternary Science Reviews, 169, 173-187. doi:10.1016/j.quascirev.2017.05.026 
Higuera, P.E., Brubaker, L.B., Anderson, P.M., Brown, T.A., Kennedy, A.T. \& Hu, F.S. (2008) Frequent fires in ancient shrub tundra: Implications of paleorecords for arctic environmental change. PLoS ONE, 3, 1-7. doi:10.1371/journal.pone.0001744

Higuera, P.E., Brubaker, L.B., Anderson, P.M., Hu, F.S. \& Brown, T.A. (2009) Vegetation mediated the impacts of postglacial climatic change on fire regimes in the south-central Brooks Range, Alaska. Ecological Monogrraphs, 79, 201-219. doi:10.1890/07-2019.1

Jowsey, P.C. (1966) An improved peat sampler. New Phytologist 65, 245-248.

R Core Team (2014) R: A language and environment for statistical computing. R Foundation for Statistical Computing, Vienna, Austria. http://www.R-project.org/.

Rhodes, A.N. (1998) A method for the preparation and quantification of microscopic charcoal from terrestrial and lacustrine sediment cores. The Holocene, 8, 113-117. doi:10.1191/095968398671104653

Stevenson, J. \& Haberle, S. (2005) Macro Charcoal Analysis: A modified technique used by the Department of Archaeology and Natural History. Australian National University, Canberra.

Tolonen, K. \& Turunen, J. (1996) Accumulation rates of carbon in mires in Finland and implications for climate change. The Holocene, 6(2), 171-178.

Wüst, R.A.J., Bustin, R.M. \& Lavkulich, L.M. (2003) New classification systems for tropical organic-rich deposits based on studies of the Tasek Bera Basin, Malaysia. Catena, 53, 133-163. 


\section{Supplementary 2}

Diagram of pollen concentration

The pollen concentrations were calculated using the following equation:

(pollen grains /lycopodium counted) $\times$

\section{total lycopodium added/sample volume}

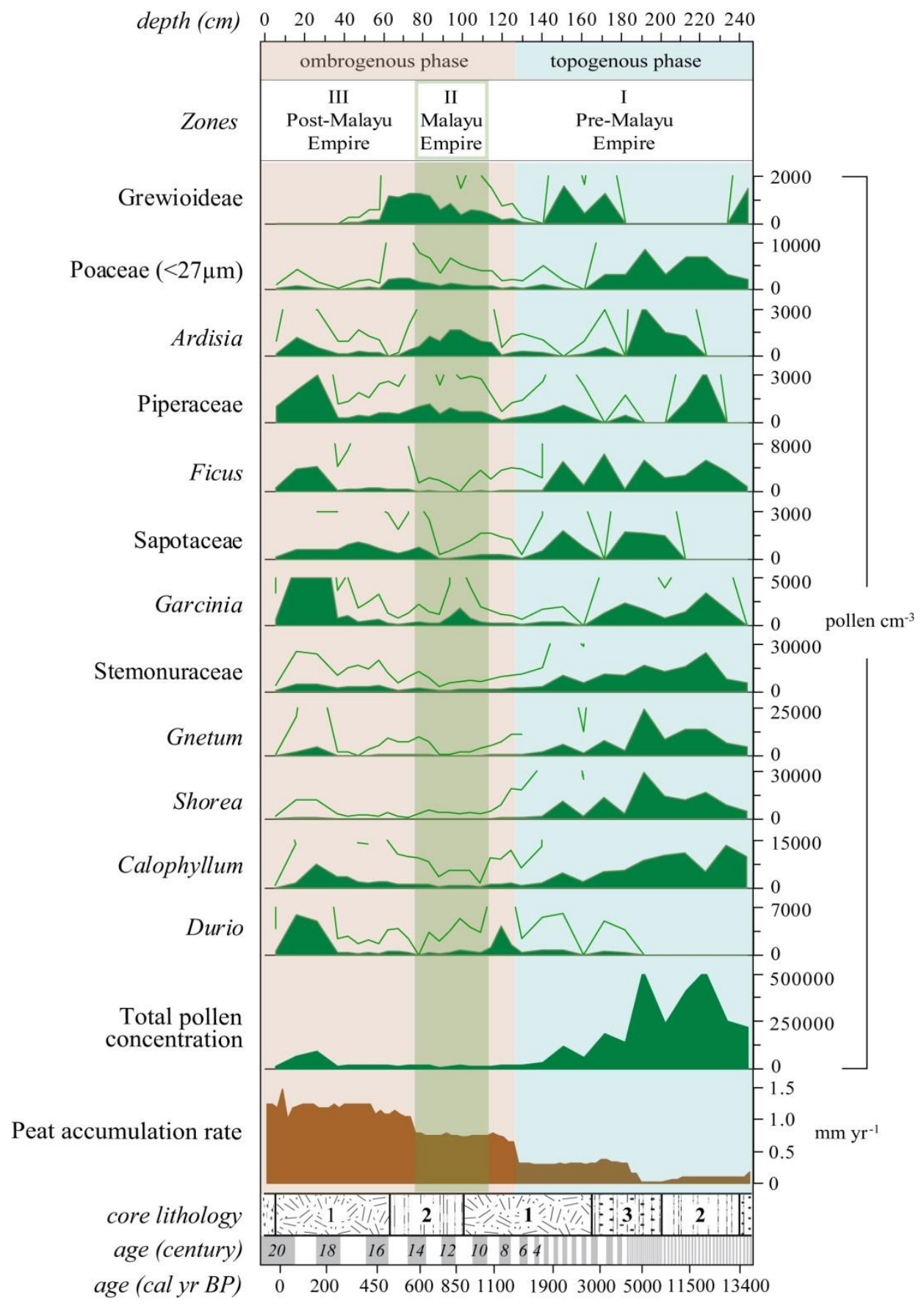


Green lines without filling represent the exaggerated values of pollen concentration.

Only the concentrations of taxa presented in the main text (Fig. 3.3) are shown. As pollen concentration appears to be inversely related to the peat accumulation rate (Dickinson, 1975), the enormous pollen concentration in the SB-B core during the topogenous phase is very likely related to its low peat accumulation rate.

\section{Reference}

Dickinson, W. (1975) Recurrence surfaces in Rusland Moss, Cumbria (Formerly North Lancashire), Journal of Ecology, 63, 913-935. doi:10.2307/2258611 


\section{Chapter 4}

Climate and land use change governed environmental dynamics and carbon accumulation in the mangrove-fringed Segara Anakan lagoon, Java, Indonesia in the Anthropocene and beyond

Kartika Anggi Hapsari ${ }^{1 *}$, Tim Jennerjahn ${ }^{2}$, Martin Lukas ${ }^{3}$, Volker Karius ${ }^{4}$, Hermann Behling ${ }^{1}$

${ }^{1}$ University of Goettingen, Department of Palynology and Climate Dynamics, 37073, Goettingen, Germany

${ }^{2}$ Dept. of Biogeochemistry and Geology, Leibniz Centre for Tropical Marine Ecology (ZMT) Bremen, Germany

${ }^{3}$ Sustainability Research Centre (artec), University of Bremen, Germany

${ }^{4}$ University of Goettingen, Dept. of Sedimentology and Environmental Geology, Geoscience Center Germany

under review 


\section{$\underline{\text { Abstract }}$}

Carbon (C) sequestration in natural sinks is currently urged with regard to global climate change mitigation. Tropical coastal wetlands are considered important in the global $\mathrm{C}$ cycle, yet knowledge on their dynamics and quantitative data are still scarce. Moreover, these ecosystems are vulnerable to land use and climate change. In order to quantify the $\mathrm{C}$ accumulation rate and to understand the relevance of land use and climate for it in the Anthropocene and beyond, a palaeoecological study was conducted in the mangrove-fringed Segara Anakan Lagoon (SAL) in Java, Indonesia. A sediment core was age dated and analyzed for its pollen and spore, elemental and biogeochemical (organic carbon, nitrogen, stable carbon and nitrogen isotope) compositions. The results indicate that the dynamics of SAL and its $\mathrm{C}$ accumulation in the past 400 years were controlled mainly by climate oscillations and anthropogenic activities. Both factors changed the lagoon's sediment supply and salinity that consequently altered the $\mathrm{C}$ burial and organic matter $(\mathrm{OM})$ deposition in the lagoon. In the future, the projected precipitation reduction over Java, as well as the increasing trend in lagoon sedimentation due to land use change in the catchment area, will likely favor the SAL's capacity to sequester C. However, widespread logging of the surrounding mangrove forest being the main organic $\mathrm{C}$ source in SAL, may diminish the lagoon's $\mathrm{C}$ accumulation capacity. Therefore, the forest in SAL needs to be maintained and improved to retain its $\mathrm{C}$ sequestration capacity, as it is currently among the highest compared to other mangrove-dominated ecosystems. Considering the urgent need for the removal of atmospheric $\mathrm{CO}_{2}$, ecosystems with a high $\mathrm{C}$ sequestration capacity, such as the mangrove-dominated Segara Anakan Lagoon, thus need to be given priority for conservation and restoration.

Keywords: Indonesia, palaeoecology, mangrove, estuary, carbon accumulation rate, land use change, climate change 


\subsection{Introduction}

Coastal lagoons often comprise very dynamic and highly productive wetland ecosystems that provide a wide range of ecosystem services, including, for example, habitats for mangrove forests, salt marshes, and aquatic biota, nutrient cycling, storm protection, fisheries, salt production, and tourism (Anthony et al., 2009; Alongi, 2012). Coastal lagoons are also important for the global carbon (C) cycle because of their high productivity and accretion rate (Twilley et al., 1992; Eong, 1993; Jennerjahn and Ittekkot, 2002; Brevik and Homburg, 2004; Chmura et al., 2003). Proportionally, coastal wetland ecosystems allocate more C below- than aboveground, in particular in their sediments (Lovelock, 2008; Alongi, 2012; Ouyang et al., 2017), highlighting the significance of belowground C storage in these ecosystems. However, as yet the data base is small (Donato et al., 2011; Ezcurra et al., 2016) and the understanding of the underlying dynamics is limited (Marchio et al., 2016).

Coastal lagoons and the ecosystem services they provide are threatened by the effects of global environmental change, such as sea level rise, which can cause coastal erosion, extreme floods, destruction of coastal wetlands, and habitat loss for aquatic biota (Anthony et al., 2009). This will simultaneously affect the social and economic conditions of human societies (Silva et al., 2013). Extensive anthropogenic pressures in coastal areas, such as land use change and natural resource exploitation, also threaten these ecosystems (Anthony et al., 2009; Silva et al., 2013). In this context mangrove ecosystems, which are lining major parts of tropical coasts, are under threat mainly from human interventions like, for example, land use conversion to agriculture and aquaculture, alterations to river catchment hydrology, timber harvesting, overexploitation of natural resources and infrastructure construction (Chowdhury et al., 2017). However, outcomes of climate change may also negatively affect them and their carbon storage potential (Alongi, 2015; Jennerjahn et al., 2017). Mangrove forests have been lost at rates of 1-2\% per year for a long time (Valiela et al., 2001). These rates have slowed 
down, nevertheless, the loss is still alarmingly high in particular in Southeast Asia (Richards and Friess, 2016).

Humans have been considered as major environmental force, as they have significantly modified biodiversity, climate, and natural cycles of e.g. nutrients, water and carbon (Raupach and Canadell, 2010; Corlett, 2015). The term Anthropocene is used to refer to the current period where humans are seen as important as natural processes in shaping the planet (Corlett, 2015). The Anthropocene is characterized by a substantial increase of anthropogenic $\mathrm{CO}_{2}$ emissions since the onset of industrialization (Raupach and Canadell, 2010), leading to climate warming, which has devastating consequences, such as sea level rise, extreme weather events, and food shortage (Huber and Gulledge, 2011; Wheeler and von Braun, 2013; Marzeion et al., 2014).

As an effort to mitigate climate warming, a global political action plan was set in place to limit the global temperature increase below $2^{\circ} \mathrm{C}$ by reducing $\mathrm{C}$ emissions (UNFCCC, 2015). However, emission-cuts alone will not be sufficient to keep global warming below $2^{\circ} \mathrm{C}$ (Rau and Greene, 2015). Efforts to reduce atmospheric $\mathrm{CO}_{2}$ through natural sequestration, e.g. conservation, restoration and improved land management, need to be undertaken (Griscom et al., 2017).

The Segara Anakan Lagoon (SAL), the last large mangrove-fringed ecosystem on the Indonesian island of Java, is a coastal wetland system that is important for C sequestration, but that has been stressed from intense human activities for centuries (Yuwono et al., 2007). SAL's biodiversity and ecosystem services, e.g. habitat and nursery ground provisions for aquatic biota, are threatened by land conversions to aquaculture/agriculture, mangrove exploitation, and high levels of sedimentation and pollution (White et al., 1989; Yuwono et al., 2007; Jennerjahn and Yuwono, 2009). 
Despite being considered a "degraded" mangrove-fringed estuarine ecosystem, soil organic carbon stocks in SAL are similar to those of some "undegraded" mangrove forests in Indonesia (Weiss et al., 2016). However, carbon accumulation and its dynamics are not known, and the knowledge of longer-term environmental dynamics is generally limited. Sedimentation, which has rapidly reduced the size of the lagoon, has been analyzed through shoreline change reconstruction going back to the mid-19 ${ }^{\text {th }}$ century (Lukas, 2014a; Lukas, 2015; Lukas, 2017), yet the longer-term sedimentation dynamics are not known.

In this paper, we provide information on the long-term environmental dynamics of SAL. This study aims (i) to quantify the $\mathrm{C}$ accumulation in lagoon sediment, (ii) to explain how climate and land use change affect lagoon dynamics and its $\mathrm{C}$ sequestration capacity, and (iii) to assess the significance of the $\mathrm{C}$ accumulation capacity of SAL in comparison to other mangrove-dominated ecosystems.

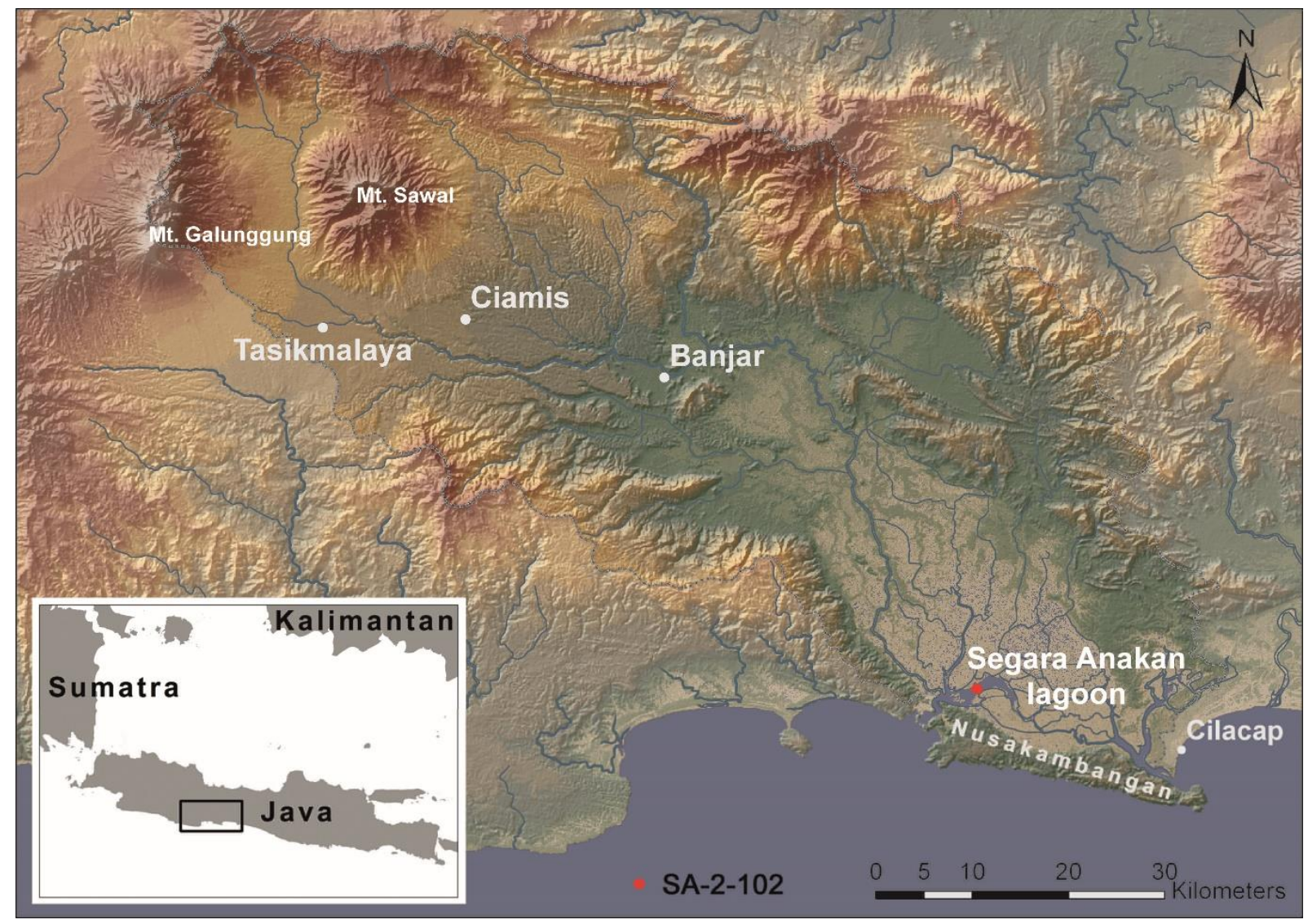

Fig. 4.1. Map of the Segara Anakan Lagoon and its catchment area. 


\subsection{Study site}

A. Ecological setting

The Segara Anakan Lagoon (SAL) is located on the southern coast of Java Island, west of the city of Cilacap (Fig. 4.1). It is surrounded by around 9,200 ha mangrove forest (Ardli and Wolff, 2009) which mainly consists of Rhizophora apiculata, Avicennia corniculatum, A. alba, Nypa fruticans, Sonneratia caseolaris and Bruguiera gymnorrhiza (Hinrichs et al., 2009). The catchment of the SAL comprises an area of around 450,000 ha, with a plain to hilly central river basin, volcanic mountains in the north-western part, and sedimentary mountains in the north-eastern and southern parts (Lukas, 2017).

SAL is separated from the Indian Ocean by the rocky mountainous Nusakambangan Island and is connected to the ocean through two channels in the West and in the East. Lagoon salinity (reported in practical salinity units (psu)) is ranging from 1 to 28 depending on freshwater input and rainfall seasonality (White et al., 1989; Noegrahati and Narsito, 2007; Holtermann et al., 2009). The salinity fluctuation is strongly influenced by the freshwater input from the Citanduy River, which contributes about $80 \%$ of the freshwater discharge into SAL with a range of 78-300 $\mathrm{m}^{3} \mathrm{~s}^{-1}$ (average $140 \mathrm{~m}^{3} \mathrm{~s}^{-1}$; Holtermann et al., 2009). A minor contribution of freshwater input comes from several smaller rivers, such as the Cibereum and Cikonde.

The tides within SAL are semidiurnal with an amplitude ranging from 0.2 to $2.6 \mathrm{~m}$ (White et al., 1989). The climate in the lagoon area is tropical humid with a mean annual temperature of $27.2^{\circ} \mathrm{C}$ and little variation throughout the year. The mean annual precipitation is $3400 \mathrm{~mm}$ with drier conditions from July to September and wetter conditions from October to May, and peak rainfall in November (Weatherbase, 2016; www.weatherbase.com). The interannual rainfall variability in this area is influenced by the El Niño Southern Oscillation (ENSO; Qian et al., 2010). 
B. Land use change in the Segara Anakan Lagoon and its hinterland

"Segara Anakan" is loosely translated as child of the sea. The lagoon is inhabited by ca. 17,300 "Orang Laut" (people of the sea) who live in the four villages of "Kampung Laut" (Sea Village) spreading across the area of Ujungalang, Ujunggagak, Klaces and Penikel (BPS Cilacap, 2017). Most residents of Kampung Laut make their living as fishers and farmers, whereby farming and aquaculture have gained importance over fishing, as sedimentation has turned substantial parts of the lagoon into land (Olive, 1998; Ardli and Wolff, 2009; Heyde, 2016; BPS Cilacap, 2017).

SAL was already populated by the descendants of guards from the Mataram kingdom, the predecessors of Orang Laut, since at least 1705 (Waryono, 2002; Schwerdtner Máñez, 2010; Mulyadi, 2013). In 1724, nine villages were documented in the SAL by Francois Valentijn, a Dutch minister and naturalist (Schwerdtner Máñez, 2010; Mulyadi, 2013). The population of Kampung Laut has risen over time, with some phases of particularly rapid growth, such as between 1924 and 1939, when the number of residents doubled from 680 to 1300 (Waryono, 2002).

According to historical records, SAL was already subjected to pearl exploitation by the Dutch in 1699 (Schwerdtner Máñez, 2010). Documentations of mangrove deforestation go back to the second half of the $19^{\text {th }}$ century. Between the 1870 s and 1930 s, rising fuelwood and charcoal demands of sugar factories and railway companies by far exceeded local lagoon residents' timber demands for houses and fishing stakes. This triggered extensive wood extraction, rendering management attempts of the colonial forest administration ineffective (de Haan, 1931).

In the course of the $20^{\text {th }}$ century, substantial mangrove and swamp forest areas surrounding the SAL and in the lower river basin further upstream have been converted into settlements, 
rice fields, and aquaculture ponds - in the frame of government-initiated resettlements and agricultural development projects, as well as by the growing population and individual settlers moving in from other parts of Java (Olive, 1998; Ardli \& Wolff 2009; Irwansyah, 2010; Lukas, 2014b, 2017). By the 1970s, the mangrove area converted to settlements and agricultural land was estimated 8-times (ca. 1,100 ha) larger than in the 1940s (ca. 140 ha; Irwansyah, 2010). Between 1968 and 1987, an additional 10,000 ha of mangrove forest was converted into rice fields (Olive, 1998; Irwansyah, 2010). Much of the remaining mangrove forest area is degraded. Tenure conflicts and mismatches between government planning and the perceptions, claims and practices of local residents on the ground impair mangrove reforestation efforts (Heyde, 2016).

The catchment/hinterland of the SAL has also experienced a long history of land use change. In the early $18^{\text {th }}$ century, the peasants of the former Priangan Regency, to which considerable sections of the lagoon's catchment belonged to, started to shift from swidden agriculture (locally called ngahuma), to permanent irrigated rice farming (sawah; Herayati et al., 1993). This agricultural system was already introduced by people from the Mataram kingdom during their reign in Priangan from 1620 to 1705 (Herayati et al., 1993; Muhzin, 2008). Compulsory coffee cultivation under the colonial regime, excessive timber extraction, plantation development, and in-migration considerably reduced forest cover in the catchment of the SAL in the $19^{\text {th }}$ and early $20^{\text {th }}$ century (Lukas, 2017). As in the whole of Java, rainfed and irrigated agriculture were considerably expanded particularly in the late $19^{\text {th }}$ and early $20^{\text {th }}$ century (Boomgaard and van Zanden, 1990; Smiet, 1990; van der Eng, 2008). The arable land area in Java increased from about 2.1 million hectares in 1880 to about 4.2 million hectares in 1915 (Boomgaard and van Zanden, 1990). In the catchment of the SAL, the expansion of both irrigated and rainfed agricultural land continued until the 1990s (Lukas, 2017). 
Most of the remaining forests were converted into monocultural production forests under the colonial Forest Service and its successor organizations (Peluso, 1992; Lukas, 2015). Today, more than one fifth of the total land area of Java is formally under the control of the state forest corporation. About $50 \%$ of these lands are planted with teak (Tectona grandis), and $36 \%$ are planted with pine (Perum Perhutani, 2016). These two species also dominate most state forest lands in the catchment of the SAL (Lukas, 2015). The pine species (Pinus merkusii) is not native to the island of Java, but was introduced from Sumatra and planted for the purpose of resin production starting in the 1920s/30s (Becking, 1935; Fitriani, 2012).

Along with the land use changes described above, forest management practices, conflicts over state forest and plantation lands, as well as erosion and mass-movements from roads, trails, and settlements raised river sediment loads and contributed to lagoon sedimentation from the late $19^{\text {th }}$ and throughout the $20^{\text {th }}$ century (Lukas, 2017). Ngaguguntur (the digging back of hill slopes to enlarge agricultural land and shoveling the excavated soil into streams and rivers), agriculture in riparian zones, and river bank erosion have also contributed to high river sediment loads (Diemont et al., 1991; Lukas, 2017). Furthermore, the reclamation of the swamp forests in the lower river basin upstream of the SAL for agriculture and settlements and extensive river straightening and embankments, which started in the first three decades of the $20^{\text {th }}$ century and which were considerably pushed forward in the frame of river and agricultural development projects in the 1970s and 80s, have contributed to sedimentation of the SAL through enhancing sediment transport (Lukas, 2015). A floodway and a river diversion constructed in the frame of these projects in the 1970s/80s have had similar effects (Lukas, 2015). 


\subsection{Materials and methods}

A. Sediment core

In 2014, a $500 \mathrm{~cm}$ long sediment core (SA-2-102; 740’S 108 $49^{\prime}$ E; Fig. 4.1) was recovered from SAL using a $5 \mathrm{~cm}$ diameter Livingstone piston corer (Wright, 1967). A short replicate core $(100 \mathrm{~cm})$ was taken ca. $20 \mathrm{~cm}$ away from the SA-2-102 borehole, because the lower half of the first meter $(67-100 \mathrm{~cm})$ of the initial core was lost.

\section{B. Sediment dating $\left({ }^{210} \mathrm{~Pb}\right.$ and $\mathrm{AMS}$ radiocarbon dating $)$}

The top $270 \mathrm{~cm}$ of the SA-2-102 core (samples from depths $60-100 \mathrm{~cm}$ were taken from the replicate core) were analyzed for ${ }^{137} \mathrm{Cs},{ }^{210} \mathrm{~Pb}$ and ${ }^{214} \mathrm{~Pb}$ at the Laboratory for Radioisotopes (ISOLAB) in Goettingen, Germany. The samples were sliced into increments of $10 \mathrm{~cm}$, dried and ground. Samples were then packed in sealed plastic tins $\left(\mathrm{ca} .35 \mathrm{~cm}^{3}\right)$ and let to rest for at least 3 weeks prior to the measurement to reach equilibrium between ${ }^{226} \mathrm{Ra}$ and ${ }^{214} \mathrm{Bi}$ (Goodbred and Kuehl, 1998). The gamma-ray measurements on ${ }^{137} \mathrm{Cs}(661.7 \mathrm{keV}),{ }^{210} \mathrm{~Pb}$ (46.6 keV) and ${ }^{214} \mathrm{~Pb}(295.2$ and $351.9 \mathrm{keV})$ were performed on each sample using three low background $\mathrm{Ge}(\mathrm{Li})$ detectors for 250,000 s (2.9 days). Three bulk samples were selected from depths 270-500 cm of SA-2-102 core and measured for Accelerator Mass Spectrometry (AMS) radiocarbon analysis at the National Taiwan University (NTU) AMS-Laboratory, Taiwan (Table 4.1). 
Table 4.1. AMS ${ }^{14} \mathrm{C}$ results of core SA-2-102. Outlier is in italic.

\begin{tabular}{|c|c|c|c|c|c|}
\hline $\begin{array}{c}\text { depth } \\
(\mathrm{cm})\end{array}$ & $\begin{array}{c}\text { Sample } \\
\text { code }\end{array}$ & Material & ${ }^{14} \mathrm{C}$ age & $\begin{array}{c}\text { Calibrated } \\
\text { age }(2 \sigma)\end{array}$ & $\begin{array}{c}\text { Posterior probability } \\
\text { (outlier analysis*) }\end{array}$ \\
\hline 228 & SA102-3 & Plant remains & $\begin{array}{c}F 14 C 1.005 \\
\pm 0.0001\end{array}$ & 100 \\
\hline 437 & SA102-2 & Plant remains & $112 \pm 1$ & $\begin{array}{c}1816-1922 \\
\mathrm{AD}\end{array}$ & 10 \\
\hline 499 & SA102-1 & $\begin{array}{c}\text { Bulk sediment } \\
\left.\sim 2 \mathrm{~cm}^{3}\right)\end{array}$ & $385 \pm 2$ & $\begin{array}{c}1480-1624 \\
\mathrm{AD}\end{array}$ & 15 \\
\hline
\end{tabular}

* using SSimple model (Christen, 1994) in OxCal (Ramsey, 2009)

\section{Pollen analysis}

Plant communities are largely shaped by climate and environmental condition (Franklin et al., 2016). Thus, identifying past vegetation and how it shifted through time could reveal the changes of climatic and/or environmental conditions in the past (Nolan et al., 2018). Palynology or the analysis of pollen and spore analysis is widely used to reconstruct the past vegetation (Nolan et al., 2018).

To assess past vegetation composition in the SAL area and its hinterland, 30 subsamples of 2 $\mathrm{cm}^{3}$ each were processed for pollen analysis following standard extraction methods (Faegri and Iversen, 1989). One tablet of Lycopodium spores was added to each subsample prior to the pollen extraction process. Pollen and spores were identified using the reference collection of pollen and spores of the Department of Palynology and Climate Dynamics, University of Goettingen, and other available literatures (e.g. Pollen and Spore Image Database of the University of Goettingen-available at http://gdvh.uni-goettingen.de/; Mildenhall and Brown, 1987; Mao et al., 2012; Li et al., 2012; Poliakova and Behling, 2016). Due to the poor pollen preservation, pollen and spores were counted up to a sum of 200 pollen grains for each sample. Pollen concentration was calculated as grains $\mathrm{cm}^{-3}$ based on the total grains of pollen counted, whereas spore concentration was calculated as grains $\mathrm{cm}^{-3}$ based on the total grains of pollen 
and spores counted. The pollen taxa were then classified into five groups according to the ecological characteristic or the function of the source plants (e.g. Sosef et al., 1998; Giesen et al., 2007; Ni et al., 2010; Wang et al., 2011; Mao et al., 2012). These groups are: (i) mangrove and mangrove associate (MMA) that represents the group of taxa that grow exclusively in mangrove areas and the associated plants; (ii) rainforest (RF) that represents the vegetation making up coastal, riparian, lowland and montane forest; (iii) open vegetation (OV) that represents the taxa that commonly grow in non-forested areas that never supported forest or resulted from disturbance such as forest clearing or conversion; (iv) staple agriculture (SA) that represents the taxa cultivated for staple food and the plants that grow on cultivated land; and (v) exotic taxa (EX) that represents introduced or non-native taxa.

\section{XRF scanning and biogeochemical analysis}

In order to trace changes in environmental conditions of the SAL, XRF scanning and analysis of total organic carbon $\left(\mathrm{C}_{\mathrm{org}}\right)$, nitrogen $(\mathrm{N})$ and the stable isotope composition of organic carbon $\left(\delta^{13} \mathrm{C}_{\text {org }}\right)$ were conducted. The XRF scanning of SA-2-102 core and the replicate core were performed at the Geomorphological-Sedimentological Laboratory of the Geomorphology and Polar Research (GEOPOLAR), University of Bremen. The sediment cores were transferred to the U-channel and scanned on the ITRAX (CS-8)-XRF scanner with Molybdenum-(Mo)-tube (Croudace et al., 2006). XRF scanning was conducted at $30 \mathrm{kV}$ and $10 \mathrm{~mA}$ in $1 \mathrm{~mm}$ resolution with $10 \mathrm{~s}$ exposure time. XRF counts were normalized against the scattering coherent (coh) peaks of Mo (Hahn et al., 2014). The data were reduced by calculating average values for $1 \mathrm{~cm}$ intervals.

$\mathrm{C}_{\text {org }}, \mathrm{N}$ and $\delta^{13} \mathrm{C}_{\text {org }}$ of SA-2-102 core were determined by analyzing 45 subsamples of $2 \mathrm{~cm}^{3}$ that were dried at $60^{\circ} \mathrm{C}$ and finely ground before analysis. $\mathrm{C}_{\mathrm{org}}$, and $\mathrm{N}$ were determined by 
high temperature oxidation in a Euro EA3000 elemental analyzer. The analytical precisions for $\mathrm{C}_{\text {org }}$ and $\mathrm{N}$ were $\pm 0.03 \%$ and $\pm 0.01 \%$, respectively.

Samples for $\mathrm{C}_{\text {org }}$ determination were treated using $1 \mathrm{~N} \mathrm{HCl}$ prior to analysis to remove carbonates. A similarly treated sample was used for determination of $\delta^{13} \mathrm{C}_{\text {org }}$ in a Thermo Finnigan Delta Plus gas isotope ratio mass spectrometer after high temperature combustion in a Flash 1112 EA elemental analyzer. The $\delta^{13} \mathrm{C}_{\text {org }}$ is reported as per mil (\%o) deviation from the carbon isotope composition of the Vienna Pee Dee Belemnite (VPDB) and the nitrogen isotope composition of atmospheric air, respectively, with $\pm 0.1 \%$ uncertainty.

\section{E. C accumulation rate}

The $\mathrm{C}$ accumulation rate of SA-2-102 was calculated by multiplying BD with total organic carbon $\left(\mathrm{C}_{\text {org }}\right)$ and sediment accumulation rates produced by the age-depth model (Section IV.A). The $\mathrm{C}$ accumulation rate is displayed as $\mathrm{g} \mathrm{C} \mathrm{m}^{-2} \mathrm{yr}^{-1}$. The sediment bulk density (BD) itself was calculated as the dry weight $(\mathrm{g})$ divided by the wet sample volume $\left(\mathrm{cm}^{3}\right)$. Subsamples of $2 \mathrm{~cm}^{3}$ were taken along the core at $5 \mathrm{~cm}$ intervals and subsequently dried at $105^{\circ} \mathrm{C}$ for $24 \mathrm{~h}$ to calculate the sediment dry weight.

\subsection{Results}

\section{A. Lithology and age control}

Both SA-2-102 and the replicate core consist mainly of silt and clay material without a clear indication of changing sediment composition (Fig. 4.2). The unsupported ${ }^{210} \mathrm{~Pb}$ activity of the core shows an irregular decrease that suggests a non-constant sedimentation rate over time (Fig. 4.2). Considering such circumstances, the use of a constant initial concentration (CIC) model for age calculation is not appropriate. The CIC model can only be applied when the activity of unsupported ${ }^{210} \mathrm{~Pb}$ declines exponentially with depth (Applebly and Oldfield, 1983; 
Appleby, 2008). Therefore, a constant rate of supply (CRS) model was chosen to calculate the age (Applebly and Oldfield, 1978; 1983).

The CRS model assumes that the atmospheric deposition of excess ${ }^{210} \mathrm{~Pb}$ is constant over time and applicable for a sediment core with a non-monotonic ${ }^{210} \mathrm{~Pb}$ profile (Applebly and Oldfield, 1978; 1983; Appleby, 2008). Moreover, CRS is widely used and considered to be more suitable to calculate ${ }^{210} \mathrm{~Pb}$ dates in lakes, coastal zones or estuaries where sedimentation processes are highly influenced by anthropogenic activities (Appleby and Oldfield, 1978; Lubis, 2006). An independent tracer such as ${ }^{137} \mathrm{Cs}$ is often used to confirm the ${ }^{210} \mathrm{~Pb}$ dates of the CRS model. However, in our case the ${ }^{137}$ Cs values from both SA-2-102 and the replicate core were constantly below the detection limit.

The calendar dates produced from the CRS model (Table 4.2) are subsequently integrated with AMS ${ }^{14} \mathrm{C}$ dates to construct an age-depth model for the whole SA-2-102 core. The agedepth model was constructed using the P-sequence depositional model in OxCal v.4.3.1 (Ramsey, 2009) with a $\mathrm{k}$ value of 1 . Prior to the construction of the age-depth model, an outlier detection was conducted using the SSimple model (Christen, 1994) in OxCal. Sample SA102-3 is flagged as an outlier by its high posterior probability and is therefore excluded from the age-depth model (Table 4.1). The discrepancy of sample SA102-3 might be attributed to bioturbation which possibly moved the sample from its correct stratigraphic position. The dates produced from this analysis are expressed as anno Domini/before Christ (AD/BC) and applied throughout the paper. The age-depth model indicates that core SA-2102 spans a time period of around 400 years from 1620 to 2014 (Fig. 4.2). 
Table 4.2. ${ }^{210} \mathrm{~Pb}$ dates of Segara Anakan core based on CRS model.

\begin{tabular}{|c|c|c|c|c|}
\hline $\begin{array}{l}\text { depth } \\
(\mathrm{cm})\end{array}$ & $\begin{array}{c}\text { unsupported } \\
{ }^{210} \mathrm{~Pb} \text { activity } \\
\left(\mathrm{Bq} \mathrm{kg}^{-1}\right)\end{array}$ & $\begin{array}{l}\text { uncertainty } \\
\left(\mathrm{Bq} \mathrm{kg}^{-1}\right)\end{array}$ & $\begin{array}{l}\text { Calendar yr } \\
\text { (AD) }\end{array}$ & $\begin{array}{l}\text { Posterior probability } \\
\text { (outlier analysis*) }\end{array}$ \\
\hline 0 & 13.7 & 3.0 & $2014 \pm 3$ & 10 \\
\hline 10 & 9.0 & 3.0 & $2011 \pm 3$ & 10 \\
\hline 20 & 7.6 & 2.9 & $2009 \pm 3$ & 10 \\
\hline 30 & 5.5 & 2.9 & $2007 \pm 3$ & 10 \\
\hline 40 & 13.2 & 3.0 & $2006 \pm 3$ & 10 \\
\hline 50 & 11.5 & 2.9 & $2002 \pm 3$ & 10 \\
\hline 60 & 7.4 & 2.9 & $1999 \pm 4$ & 10 \\
\hline 70 & 8.7 & 3.0 & $1996 \pm 4$ & 10 \\
\hline 80 & 9.1 & 2.8 & $1994 \pm 4$ & 10 \\
\hline 90 & 18.4 & 3.0 & $1991 \pm 4$ & 10 \\
\hline 100 & 12.8 & 2.9 & $1984 \pm 4$ & 10 \\
\hline 120 & 7.4 & 2.9 & $1977 \pm 5$ & 10 \\
\hline 110 & 8.8 & 2.9 & $1970 \pm 5$ & 10 \\
\hline 130 & 13.0 & 2.9 & $1964 \pm 5$ & 10 \\
\hline 140 & 9.5 & 2.9 & $1948 \pm 7$ & 10 \\
\hline 150 & 10.9 & 2.9 & $1929 \pm 9$ & 10 \\
\hline 160 & 0.7 & 2.6 & & \\
\hline 170 & 4.5 & 2.8 & & \\
\hline 180 & 2.6 & 2.7 & & \\
\hline 190 & 4.0 & 2.7 & & \\
\hline 200 & 0.4 & 2.5 & & \\
\hline 210 & -0.9 & 2.5 & & \\
\hline 220 & 1.5 & 2.5 & & \\
\hline 230 & 2.0 & 2.5 & & \\
\hline 240 & 1.2 & 2.5 & & \\
\hline 250 & 1.5 & 2.6 & & \\
\hline 260 & 2.8 & 2.5 & & \\
\hline
\end{tabular}

* using SSimple model (Christen, 1994) in OxCal (Ramsey, 2009) 
OxCal v4.3.1 Bronk Ramsey (2017); r:5 SHCal13 atmospheric curve (Hogg et al., 2013)

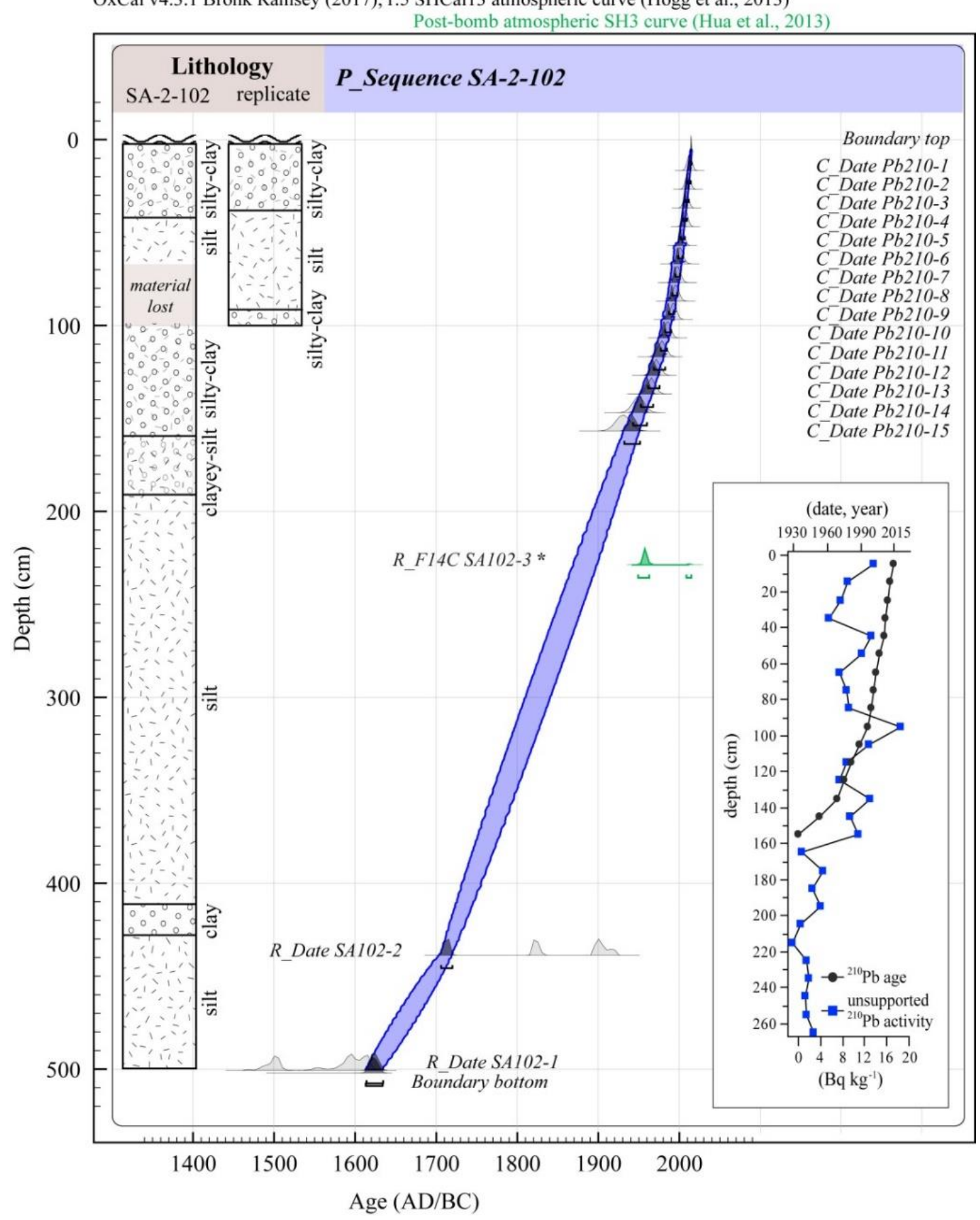

Fig. 4.2. Lithology and age-depth model of cores taken from the Segara Anakan Lagoon. The age-depth model was constructed using the P-sequence in OxCal v 4.3.1 (Ramsey, 2009) and the initial ShCal.13 and PostBomb calibration curves (Hogg et al., 2013; Hua et al., 2013). The unsupported ${ }^{210} \mathrm{~Pb}$ activity and ${ }^{210} \mathrm{~Pb}$ dates are presented in the insert. An outlier date is marked with an asterisk $(*)$. 


\section{B. Pollen analysis, XRF and biogeochemical analysis}

The detailed results of pollen, XRF and biogeochemical analyses are comprised in Table 4.3. The pollen record of SAL is divided into five palynological zones with two subdivisions in zone II (Fig. 4.3) based on the agglomeration in a constrained cluster analysis (CONISS; Supplementary S2; Grimm, 1987). The same zonation is used to divide the results of XRF scanning and biogeochemical analyses, and also the calculation of $\mathrm{C}$ accumulation rates.

Zones I, II and IV are dominated by the MMA (mangroves and mangrove associates) pollen group, while zones III and V are dominated by SA (staple agriculture). The proportion of pollen group RF (rainforest) and OV (open vegetation) are relatively stable throughout the record with a higher RF proportion in zone IV, and a lower OV proportion in zones I and IV. The pollen group EX (exotic species) contributes only a small proportion throughout the record.

The results of XRF scanning are shown as element count per second (cps) at each measuring point. Selected elements, sulfur $(\mathrm{S})$, chlorine $(\mathrm{Cl})$, bromine $(\mathrm{Br})$, titanium $(\mathrm{Ti})$ and calcium (Ca) are reported in the XRF profile (Fig. 4.4). Those elements show notable increase in Zone IV, except for Ti that shows a slight decrease.

The values of $\mathrm{N}$ are relatively stable throughout the record $(0.11 \%)$, while the $\mathrm{C}_{\text {org }}$ values fluctuate from 0.9 to $2.9 \%$ with higher values in zone IV (Fig. 4.4). Consequently, the $\mathrm{C}_{\text {org }} / \mathrm{N}$ ratio is also higher in zone IV. The $\delta^{13} \mathrm{C}_{\text {org }}$ values fluctuate from -22 to $-28 \%$ (average $-26 \%$ ) throughout the record, with lower values in zones IIa and IV (Fig. 4.4). 
Table 4.3. Results of pollen analysis, XRF scanning and biogeochemical analysis. Values presented are in average.

\begin{tabular}{|c|c|c|c|}
\hline $\begin{array}{c}\text { Zonation } \\
\text { (depth and age) }\end{array}$ & $\begin{array}{c}\text { Pollen analyses* } \\
\text { (Fig. 4.3) }\end{array}$ & $\begin{array}{c}\text { XRF profile } \\
(\text { Fig. } 4.4)\end{array}$ & $\begin{array}{c}\text { Biogeochemical analysis } \\
\text { (Fig. 4.4) }\end{array}$ \\
\hline $\begin{array}{c}\text { SA-I } \\
500-486 \mathrm{~cm} \\
1620-1640\end{array}$ & $\begin{array}{c}\text { 56\% MMA (e.g. } \\
\text { Rhizophora, Nypa, } \\
\text { Bruguiera and } \\
\text { Avicennia); 5\% SA (e.g. } \\
\text { Oryza-type, Colocasia } \\
\text { and Solanaceae); } 6 \% \\
\text { OV (e.g. wild Poaceae } \\
\text { and Asteraceae); 33\% } \\
\text { RF (e.g. Moraceae- } \\
\text { Urticaceae, Arecaceae, } \\
\text { Nauclea, Pometia and } \\
\text { Podocarpus); 0\% EX } \\
\text { (Pinus) }\end{array}$ & \multirow{4}{*}{$\begin{array}{c}\mathrm{S}, \mathrm{Cl} \text { and } \mathrm{Br} \\
\text { (exponentially } \\
\text { decrease towards } \\
\text { present time) } \\
\\
\mathrm{Ti} / \mathrm{Ca} \\
\text { (exponentially } \\
\text { increases } \\
\text { towards present } \\
\text { time) }\end{array}$} & \multirow[t]{2}{*}{$\begin{array}{c}\mathrm{C}_{\text {org }}(1.6 \%) ; \mathrm{N}(0.11 \%) \\
\mathrm{C}_{\text {org }} \mathrm{N}(12) ; \delta^{13} \mathrm{C}_{\text {org }}(- \\
26.7 \% 0)\end{array}$} \\
\hline $\begin{array}{c}\text { SA-IIa } \\
435-486 \mathrm{~cm} \\
1640-1700\end{array}$ & $\begin{array}{c}\text { 50\% MMA ( } \boldsymbol{\nabla}) ; 7 \% \text { SA } \\
(\mathbf{\Delta}) ; 18 \% \text { OV }(\boldsymbol{\Delta}) ; \\
25 \% \text { RF }(\boldsymbol{\nabla}) ; 0 \% \text { EX } \\
(\leftrightarrow)\end{array}$ & & \\
\hline $\begin{array}{c}\text { SA-IIb } \\
335-435 \mathrm{~cm} \\
1700-1790\end{array}$ & 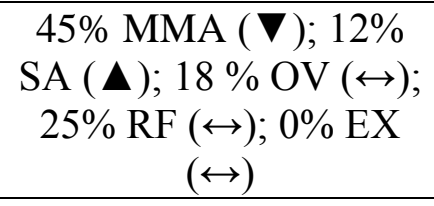 & & $\begin{array}{c}\mathrm{C}_{\text {org }}(1.5 \% ; \boldsymbol{\nabla}) ; \mathrm{N}(0.11 \% ; \\
\leftrightarrow) ; \\
\mathrm{C}_{\text {org }} \mathrm{N}(10 ; \boldsymbol{\nabla}) ; \\
\delta^{13} \mathrm{C}_{\text {org }}(-25.3 \% ; \boldsymbol{\Delta})\end{array}$ \\
\hline $\begin{array}{c}\text { SA-III } \\
295-335 \mathrm{~cm} \\
1790-1830\end{array}$ & 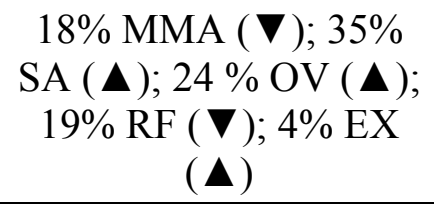 & & $\begin{array}{c}\mathrm{C}_{\text {org }}(1 \% ; \boldsymbol{\nabla}) ; \mathrm{N}(0.11 \% \\
\leftrightarrow) \\
\mathrm{C}_{\text {org }} \mathrm{N}(7 ; \boldsymbol{\nabla}) \\
\delta^{13} \mathrm{C}_{\text {org }}(-25.7 \% ; \boldsymbol{\nabla})\end{array}$ \\
\hline $\begin{array}{c}\text { SA-IV } \\
295-190 \mathrm{~cm} \\
1830-1910\end{array}$ & $\begin{array}{c}\text { 49\% MMA ( } \mathbf{\Delta}) ; 5 \% \text { SA } \\
(\boldsymbol{\nabla}) ; 11 \% \text { OV }(\boldsymbol{\nabla}) ; \\
35 \% \operatorname{RF}(\mathbf{\Delta}) ; 0 \% \mathrm{EX} \\
(\boldsymbol{\nabla})\end{array}$ & $\begin{array}{c}\mathrm{S}, \mathrm{Cl} \text { and } \mathrm{Br}(\boldsymbol{\Delta}) \\
\mathrm{Ti} / \mathrm{Ca}(\boldsymbol{\nabla})\end{array}$ & $\begin{array}{c}\mathrm{C}_{\text {org }}(2.1 \% ; \boldsymbol{\Delta}) ; \mathrm{N}(0.11 \% ; \\
\leftrightarrow) ; \\
\mathrm{C}_{\text {org }} \mathrm{N}(16 ; \boldsymbol{\Delta}) ; \\
\delta^{13} \mathrm{C}_{\mathrm{org}}(-27.7 \% ; \boldsymbol{\nabla})\end{array}$ \\
\hline $\begin{array}{c}\text { SA-V } \\
190-0 \mathrm{~cm} \\
1910-2014\end{array}$ & 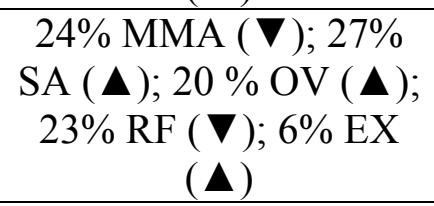 & $\begin{array}{c}\mathrm{S}, \mathrm{Cl} \text { and } \mathrm{Br}(\boldsymbol{\nabla}) \\
\mathrm{Ti} / \mathrm{Ca}(\boldsymbol{\Delta})\end{array}$ & $\begin{array}{c}\mathrm{C}_{\text {org }}(1.2 \% ; \boldsymbol{\nabla}) ; \mathrm{N}(0.11 \% ; \\
\leftrightarrow) ; \\
\mathrm{C}_{\text {org }} \mathrm{N}(9 ; \boldsymbol{\nabla}) ; \\
\delta^{13} \mathrm{C}_{\mathrm{org}}(-25.7 \% ; \mathbf{\Delta})\end{array}$ \\
\hline
\end{tabular}

$\boldsymbol{\Lambda}$ : value increase $\boldsymbol{\nabla}$ : value decrease $\leftrightarrow$ : value stable

*: pollen group abbreviation (see Section III.C.) 


\section{C accumulation rate}

The BD values are relatively stable throughout the SA-2-102 core ranging from 0.5 to $0.9 \mathrm{~g}$ $\mathrm{cm}^{-3}$ (average $0.7 \mathrm{~g} \mathrm{~cm}^{-3}$; Fig. 4.5). The average rate of sediment accumulation over the entire period is $1.6 \mathrm{~cm} \mathrm{yr}^{-1}$ (range 0.7 to $5 \mathrm{~cm} \mathrm{yr}^{-1}$ ) with a minimum in Zone I and IIa $\left(0.7 \mathrm{~cm} \mathrm{yr}^{-1}\right)$ and a maximum in Zone $\mathrm{V}\left(2.2 \mathrm{~cm} \mathrm{yr}^{-1}\right.$; Fig. 4.5). The temporal variation of the $\mathrm{C}$ accumulation rate generally mirrors the trend of the sediment accumulation rate (average 126 $\mathrm{g} \mathrm{C} \mathrm{m}^{-2} \mathrm{yr}^{-1}$; range 55-370 $\mathrm{g} \mathrm{C} \mathrm{m}^{-2} \mathrm{yr}^{-1}$ ), except for Zone IV (Fig. 4.5). 


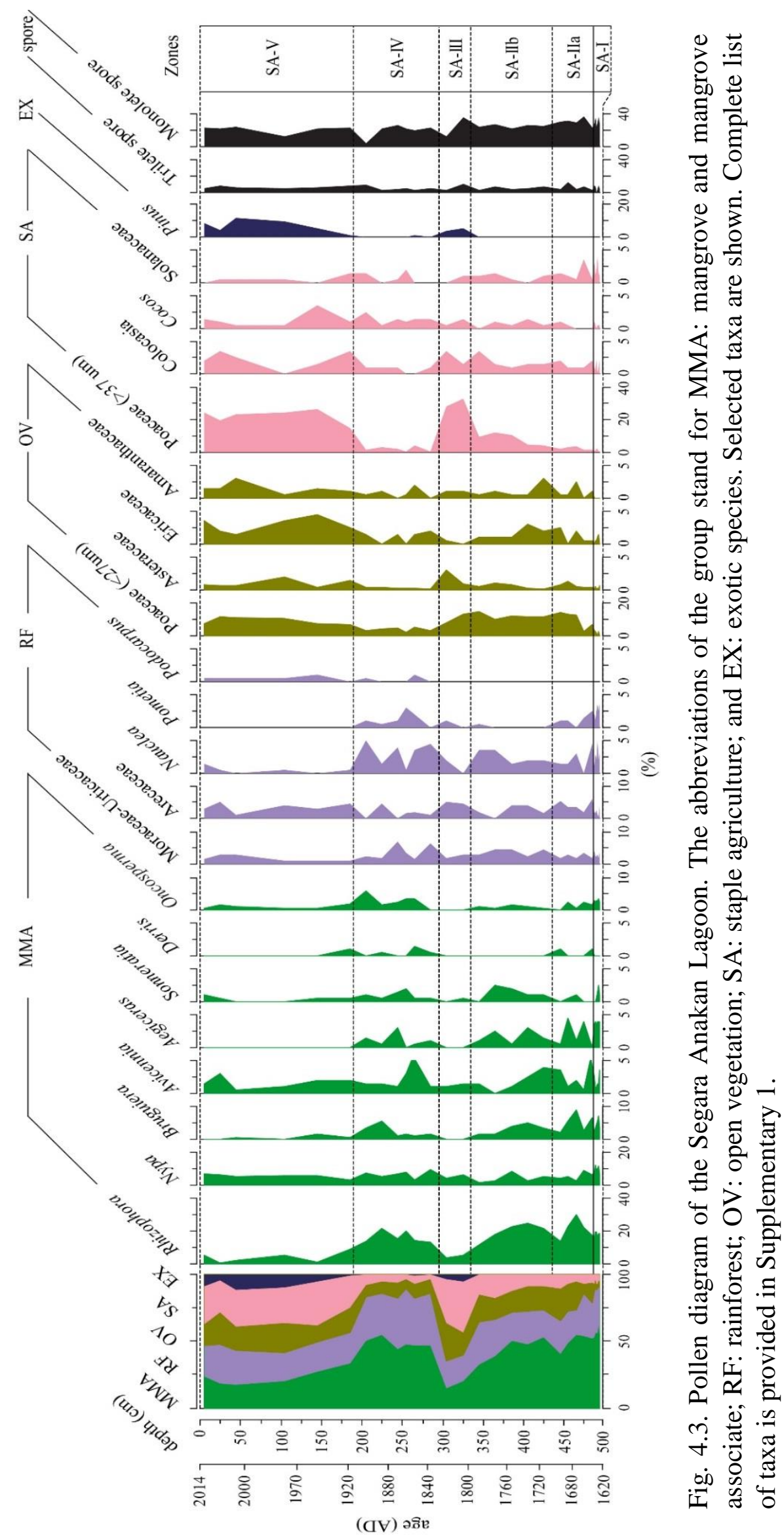




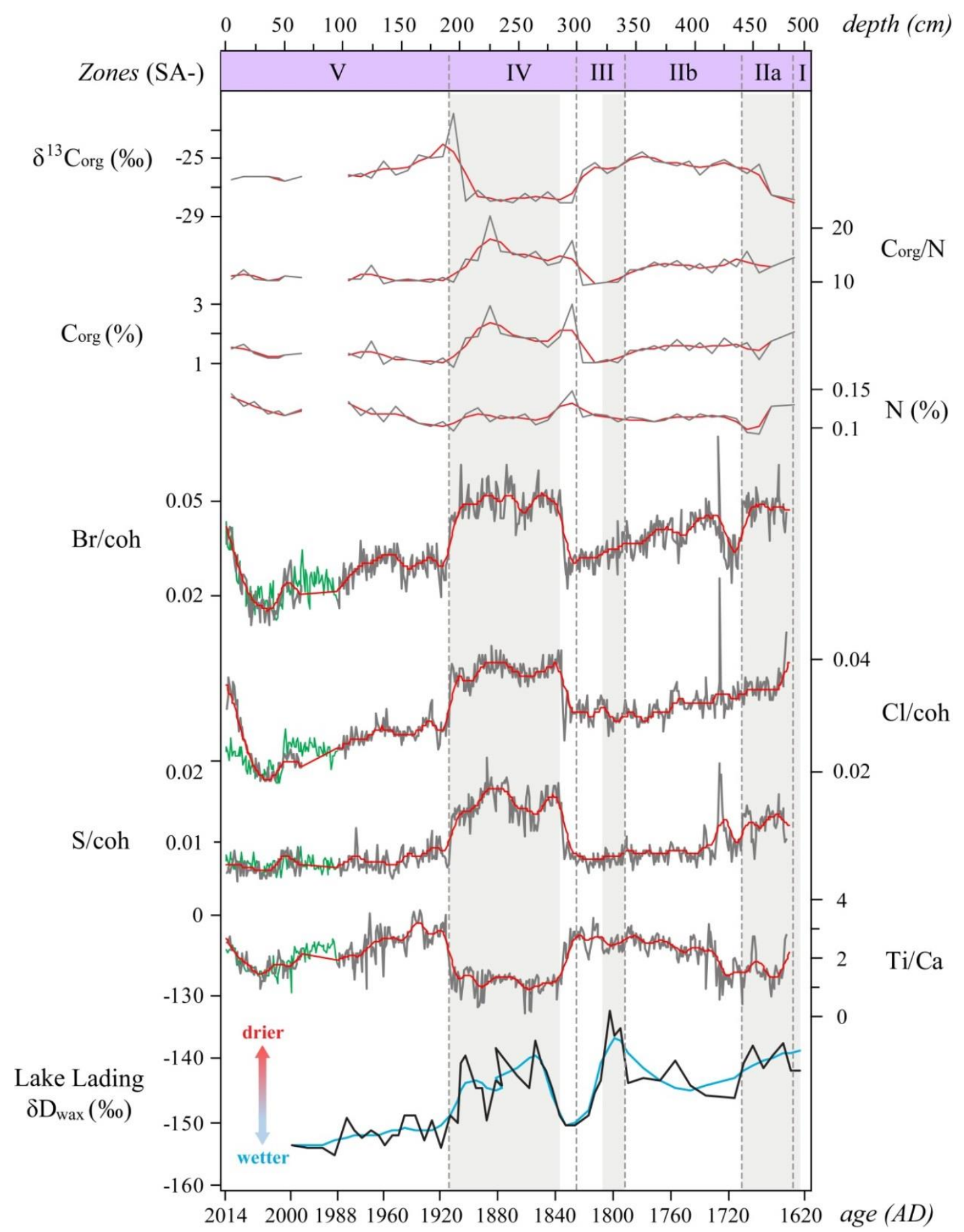

Fig. 4.4. Combined diagram of selected elements (Ti/Ca, $\mathrm{Br}, \mathrm{S}, \mathrm{Cl}$; green lines represent results from the replicate core) and biogeochemistry $\left(\mathrm{C}_{\text {org }}, \mathrm{N}, \mathrm{C}_{\text {org }} / \mathrm{N}\right.$ and $\delta^{13} \mathrm{C}_{\text {org }}$ ), in comparison with precipitation of Lake Lading (Java) derived from $\delta \mathrm{D}_{\text {wax }}$ (Konecky et al., 2003; the raw $\delta \mathrm{D}_{\text {wax }}$ data are denoted by the black lines while the low-pass filter data are presented in blue). The reported XRF elements are normalized with coherent (coh) peaks. The periods of lower precipitation are highlighted by the 


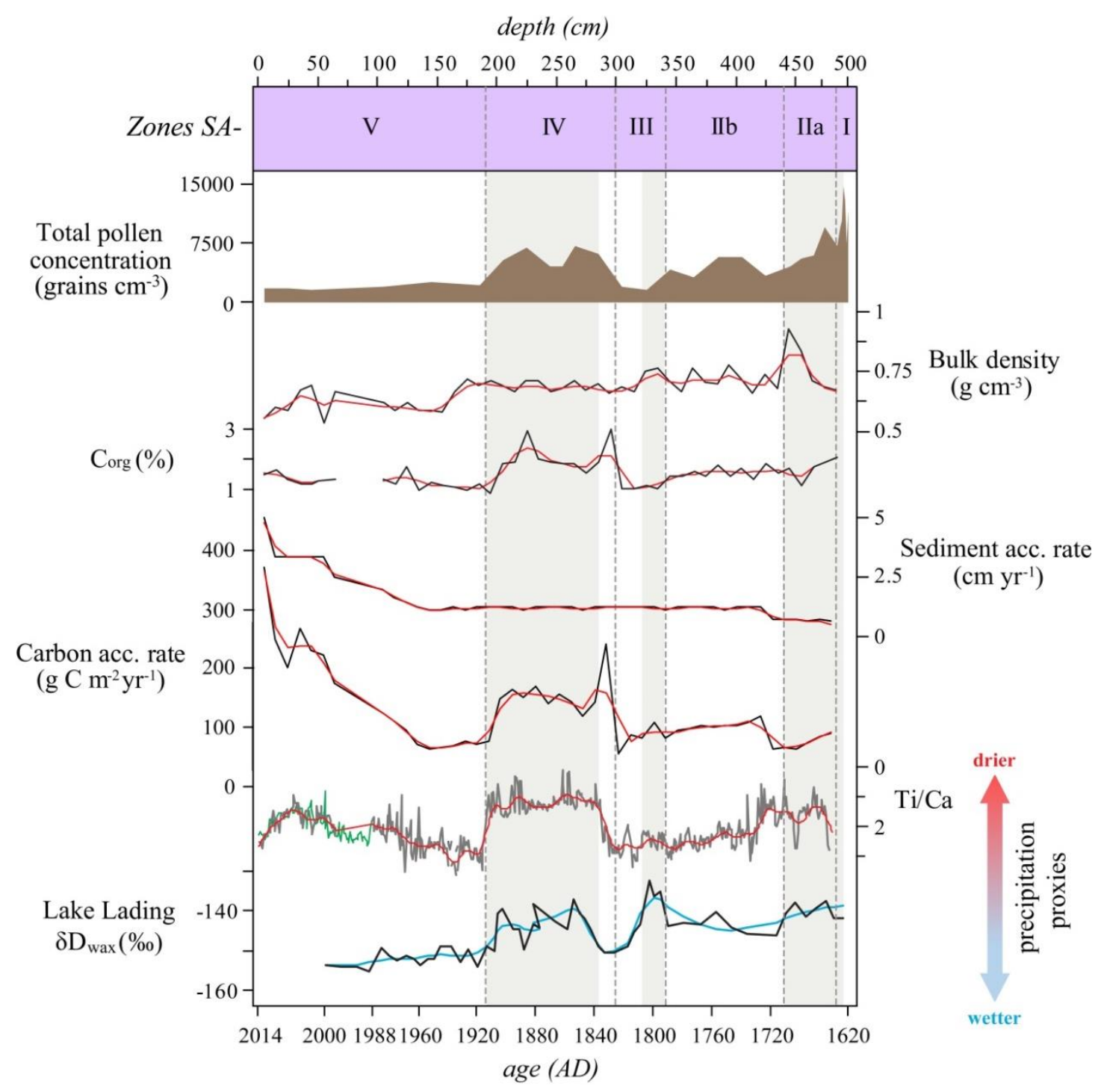

Fig. 4.5. Sediment accumulation rate, bulk density, $\mathrm{C}_{\text {org }}$ content and $\mathrm{C}$ accumulation rate of SAL in comparison with precipitation proxies of Ti/Ca (SAL) and $\delta \mathrm{D}_{\text {wax }}$ (Lake Lading, Java; Konecky et al., 2003). Raw $\delta D_{\text {wax }}$ data are denoted by the black lines while the low-pass filter data are presented in blue. The periods of lower precipitation are highlighted by the grey bars.

\subsection{Discussion}

\subsubsection{Segara Anakan lagoon dynamics}

1. The early period $1620-1830 \mathrm{AD}$

The sediment accumulation rate and the $\mathrm{Ti} / \mathrm{Ca}$ ratio were relatively low from 1620 to 1700 (Fig. 4.4). During the same period, the values of $\mathrm{Br}, \mathrm{S}$ and $\mathrm{Cl}$ were considerably 
higher than in the following. Concomitantly, around the same time interval, between 1600 and 1690, a period of decreasing precipitation was reported in Java (Konecky et al., 2013).

A low Ti/Ca ratio indicates a low detrital input from rivers or runoff (Mohtadi et al., 2011; Steinke et al., 2014). Meanwhile, the higher values of $\mathrm{Br}, \mathrm{S}$ and $\mathrm{Cl}$ suggest a higher marine input into the lagoon (Burton et al, 2000; Haenssler et al., 2014). The lower precipitation from 1600 to 1690 likely played a role in reducing sediment transport from the catchment area by limiting surface runoff and freshwater discharge from the river. Consequently, the sediment accumulation rate was low during this period and lagoon salinity was higher.

According to the pollen abundance and composition, from 1620 to around 1700 the vegetation surrounding SAL was dominated by mangrove forest, with the dominant species being Rhizophora, Bruguiera, Avicennia, Aegiceras and Nypa, with some rainforest vegetation (Fig. 4.3, Supplementary 3$)$. The domination of mangrove $\left(\delta^{13} \mathrm{C}_{\text {org }}\right.$ range -28 to $-25 \%$; Rodelli et al., 1984) and rainforest $\left(\delta^{13} \mathrm{C}_{\text {org }}\right.$ range -38 to $-26 \%$; Ometto et al., 2006) vegetation is also confirmed by an average $\delta^{13} \mathrm{C}_{\text {org }}$ of $-26.7 \%$. A rather 'natural' environmental condition as suggested by the domination of mangrove and rainforest vegetation, likely minimized erosion in the hinterland and hence limited the sediment input into SAL during this period.

The sedimentation rate doubled after 1700 . This was accompanied by an increase of the $\mathrm{Ti} / \mathrm{Ca}$ ratio and decreasing values of $\mathrm{Br}, \mathrm{S}$, and $\mathrm{Cl}$. It indicates a higher sediment input from the hinterland as a result of a generally increasing precipitation in Java after 1690 (Konecky et al., 2013). This may also have reduced the intrusion of sea water into the lagoon and kept lagoon salinity low. Rainfall intensification that decreased salinity is 
also mentioned in the record of pearl fishing in SAL. It was reported that an 'unseasonal rainfall killed the young oyster' in 1722 (Schwerdtner Máñez, 2010 and references therein).

Around 1700 and thereafter, the proportion of the wild Poaceae, Ericaceae and Amaranthaceae as well as the cultivated Poaceae pollen increased (e.g. Oryza, Sorghum, Saccharum, Panicum, Setaria) followed by a decreasing proportion of mangrove pollen (Fig. 4.3; Table 4.3). These changes are corroborated by similar trends in the pollen concentration of the aforementioned taxa (Supplementary 3) and a higher $\delta^{13} \mathrm{C}_{\text {org }}$ value, which indicates an admixture of $\mathrm{C} 4$ plants to the deposited organic matter (OM; Meyers, 1994; França et al., 2013; Fig. 4.4).

Considering that SAL was already inhabited by "Orang Laut" at that time (Section II.B), the decline in mangrove forest in this period was likely related to human mangrove forest utilization. The residents of Kampung Laut utilized mangrove wood mainly for house construction (Waryono, 2002; Mulyadi, 2013). The increase of cultivated Poaceae in the pollen record throughout the $18^{\text {th }}$ century (Fig. 4.3; Table 4.3) likely reflects the onset of larger-scale anthropogenic land use changes in the lagoon's catchment area (Section II.B).

The first occurrence of pine pollen (Pinus sp.) in the sediment record in the early $19^{\text {th }}$ century (Fig. 4.3) suggests that it was introduced to Java earlier than previously thought. It was reported that pine was introduced from Sumatra in the frame of small scale trials in the 1920s and was then planted on a larger scale in the 1930s (Becking, 1935; Fitriani, 2012). However, pine could have been introduced earlier to Java as forest species or the pine pollen are transported by wind into the Segara Anakan catchment area and subsequently transported along the river into the lagoon, considering that the bisaccate 
morphology of Pinus pollen allows for long-distance wind-transport (ca. $300 \mathrm{~km}$; Reitz and Shackley, 2012; Twiddle et al., 2012).

\section{The $1830-1910$ drought period}

A period of drier climatic conditions from 1830 to 1910 (Konecky et al., 2013) is reflected in several records of drought-related crop failures in Java in 1832-1836, 18441848, 1849-51, 1858-62, 1877-88 and 1900-02 (Creutzberg and van Laanen, 1987; Boomgaard, 2002; Fernando, 2010; van der Eng, 2010). As suggested by a lower Ti/Ca ratio and higher values of $\mathrm{Br}, \mathrm{Cl}$ and $\mathrm{S}$ (Fig. 4.4), the 1830-1910 droughts in Java reduced freshwater input into the SAL, hence lagoon salinity increased. During this period, the $\delta^{13} \mathrm{C}_{\text {org }}$ value decreased to an average of $-27.7 \%$ and the $\mathrm{C}_{\text {org }} / \mathrm{N}$ ratio increased to 16, suggesting less admixture of OM from non-woody vegetation (Meyers, 1994). This is corroborated by a higher proportion of mangrove (e.g. Rhizophora, Bruguiera and Avicennia) and rainforest (e.g. Nauclea, Moraceae-Urticaceae and Pometia) pollen and a lower proportion of cultivated Poaceae and Pinus pollen (Fig. 4.3). Similar trends in their absolute terms, i.e. pollen concentration, were observed (Supplementary 3). In fact, during the 1830-1910 drought period, the total pollen and almost all pollen displayed a higher concentration, except for wild-grass Poaceae and cultivated Poaceae (>37 um), suggesting they were likely transported by a river (Fig. 4.5 and Supplementary 3).

Under the common assumption that the pollen-spore assemblage in the sediment reflects the surrounding vegetation at the time of their deposition (Bradley, 1999), such changes in the pollen record of Segara Anakan indicate the expansion of mangrove and rainforest surrounding the lagoon. However, in interpreting pollen assemblages 
attention needs to be paid to taphonomy, the process transforming plant communities into pollen assemblages, for example by pollen deposition (Goring et al., 2013). In a water body, the deposition of pollen grains commonly relies upon two factors: its settling velocity and water movement (Brush and Brush, 1972). Those factors strongly control the pollen suspension time in the water column (Brush and Brush, 1972).

Lower river discharge during the 1830-1910 drought period likely increased pollen deposition by reducing water flow velocity, hence allowing the suspended pollen grains to settle to the lagoon floor. In an estuarine environment, the pollen deposition rate is also influenced by encapsulation in floccules of clay, silt and organic particles (e.g. amorphous OM, phytoclasts and palynomorphs), the formation of which (=flocculation) largely depends on the salt concentration (Chmura and Eisma, 1995; Gastaldo and Feng, 1996; Gastaldo, 2012). Higher salt contents cause fine particles to stick together and to form larger and heavier aggregates, which thus settle more rapidly (Sutherland et al., 2014).

In addition to that, lower river discharge resulted in lower sediment input into the lagoon hence reduced the effect of sediment dilution (Fig. 4.5). Commonly, in an ecosystem where pollen mainly originate from local vegetation, which is the case in the SAL, sediment accumulation is inversely reflected in total pollen concentration (Brush, 1989). This means that pollen concentration will increase whenever mineral input decreases, and vice versa (Brush, 1989). The higher proportion and concentration of mangrove and rainforest pollen during the 1830-1910 drought period are therefore likely influenced by the changes in the pollen deposition mechanisms and the effect of sediment dilution, rather than by the expansion of the plant source itself. 


\section{The last century (1910 until present)}

After 1910, the pollen record indicates a decline of mangrove forest and most of the rainforest taxa (Fig. 4.3). The pollen record also indicates an increase of herbaceous plants, such as wild Poaceae and Ericaceae, and of coconut trees (Cocos; Fig. 4.3) which are commonly cultivated throughout the lagoon's catchment area. These changes are confirmed by similar trends in their absolute terms (Supplementary 3), a higher $\delta^{13} \mathrm{C}_{\text {org }}$ indicating the addition of $\mathrm{C} 4$ plant-derived $\mathrm{OM}$, and a lower $\mathrm{CN}$ ratio that suggests the decline of vascular plant OM input (Meyers, 1994; França et al., 2013; Fig. 4.4).

Despite being likely exaggerated by the dilution effect following a higher sediment input, the decline of mangrove taxa in the pollen record conforms to documentation of mangrove uses and land conversions. The drastic decline of Bruguiera in the pollen record around the turn to the 20th century is in line with a forest inventory by de Haan (1931), who found that the Bruguiera stands were particularly exploited and degraded, with only very limited regrowth. While exploitation of Rhizophora first remained limited to 100-200 meter corridors along the creek shores (de Haan, 1931), our pollen record indicates a massive decline of the Rhizophora stands until the 1940s. In addition to the wood demand of the colonial industry, local uses of mangrove wood and the expansion of agricultural land by the growing population also contributed to the decline of mangrove cover.

The pollen record also suggests an increase of cultivated Poaceae and the exotic taxon Pinus after 1910 (Fig. 4.3). The increase of cultivated Poaceae in our pollen record likely reflects the increase in rice cultivation in the catchment area of the SAL since the 
early $20^{\text {th }}$ century. Meanwhile, the increase of Pinus pollen reflects the expansion of pine plantations in the hinterland. Although teak (Tectona grandis) was and is also widely planted in Java, its pollen is not captured by the pollen record. In contrast to Pinus spp. that produces a high amount of pollen, which can be transported over long distances (Twiddle et al., 2012), Tectona spp. is known to produce a high amount of pollen, but its pollen are poorly preserved and have a low dispersal efficiency (Quamar and Bera, 2014).

The sediment core indicates rapidly increasing sedimentation after 1960 (Fig. 4.2 and 4.5). This is roughly in line with the results of a historical-cartographic and remote sensing analysis of lagoon shore line changes (Lukas, 2014a; 2017), which shows continuously increasing sedimentation between the first half of the 20th century and the 1990s - with aggradation progressing from the northern to the southern parts of the lagoon, where the sediment core was taken. The causes of increasing sedimentation in the second half of the $20^{\text {th }}$ century include the expansion of rainfed agriculture, erosion on contested state forest and plantation lands, erosion on roads trails and in expanding settlement areas, ngaguguntur (the digging back of hill slopes), agriculture in riparian zones, and river and floodplain modifications, including the removal of river meanders (Lukas, 2017). Meander removal and river straightening artificially shortens the water flow distance and steepens the slope (Sapkota, 2017). This increases water velocity and enhances streambank and bed erosion, thus contributing to increased sediment input into the lagoon. Furthermore, a floodway was constructed to divert the peak floods of the Citanduy into the Cibeureum River and to redirect part of the high sediment load into the northern part of the lagoon, where much of it is deposited, instead of being transported to the ocean (Lukas, 2017). 


\subsubsection{Carbon sequestration in the Segara Anakan Lagoon}

1. Temporal variation in $\mathrm{C}$ accumulation rates

The temporal variation in the $\mathrm{C}$ accumulation greatly resembles the variation in the sediment accumulation rates (Fig. 4.5). An exception occurs during the 1830-1910 drought period when the $\mathrm{C}_{\text {org }}$ content was higher (Fig. 4.5). Sediment input indeed contributes to the preservation and burial of $\mathrm{C}_{\text {org }}$ (Schwarzbauer and Jovančićević, 2015). However, in case of a very high sediment accumulation, as in the SAL, $\mathrm{C}_{\text {org }}$ can be diluted by the inorganic clastic material, i.e. the $\mathrm{C}_{\text {org }}$ concentration may decrease with an increasing sediment supply (Tyson, 2001). Such "dilution" only reduces the $\mathrm{C}_{\text {org }}$ concentration in the sediment and not its total amount (Schwarzbauer and Jovančićević, 2015). Thus, in turn, a lower sediment input would reduce the dilution effect and result in higher $\mathrm{C}_{\text {org }}$ concentrations as observed in the SAL during the 1830-1910 drought period (Fig. 4.5).

Salinity-induced flocculation could also play a role in increasing the $\mathrm{C}_{\text {org }}$ content in the SAL during the 1830-1910 drought period. Organic particles, like silt and clay, possess a negative charge and consequently repel each other, which prevents them from aggregating (Roberts et al., 2006). Increased lagoon salinity adds to the cationic charge that limits or eliminates the repulsion effect (Shamlou, 1993; Somasundaran, 2006). This allows the organic particles in SAL, which based on the $\delta^{13} \mathrm{C}_{\text {org }}$ values sourced mainly from mangrove (Fig. 4.4; Meyers, 1994; França et al., 2013), to undergo flocculation along with silt and clay particles.

This, in turn, suggests that changes in salinity might play an important role in determining variations in the CAR of the SAL. Salinity-induced flocculation was also 
suggested to be an important mechanism in soil $\mathrm{C}$ accumulation in mangrove ecosystems by a recent experimental study (Kida et al., 2017). It was observed that humic substances exist in floccules that were formed due to the supply of sea water into the ecosystem. The reduction of salinity in a mangrove ecosystem would then lead to a breakdown of floccules, hence the release of humic substances from flocculation (Kida et al., 2017).

\section{Significance of long-term $\mathrm{C}$ sequestration rates of Segara Anakan lagoon}

Estimating the ecosystem's C accumulation capacity by measuring short-term C sequestration using surface sediment $(\leq 10$ years; $\pm 5-\mathrm{cm}$ depth $)$ would lead to an overestimation (Donato et al., 2011; Breithaupt et al., 2014). This is primarily due to the fact that the surface sediment is vulnerable to remineralization and erosion (Breithaupt et al., 2014). On the other hand, using longer-term CAR measurements, e.g. a 50- to 100-year timeframes, would suppress the bias of temporal scale and reduce the spatial variability (Breithaupt et al., 2014). Also, a 100-year timespan is considered to "provide the most conservative forecast of the regional long-term rates" for a longer-term $\mathrm{C}$ sequestration assessment in coastal wetlands (Breithaupt et al., 2014).

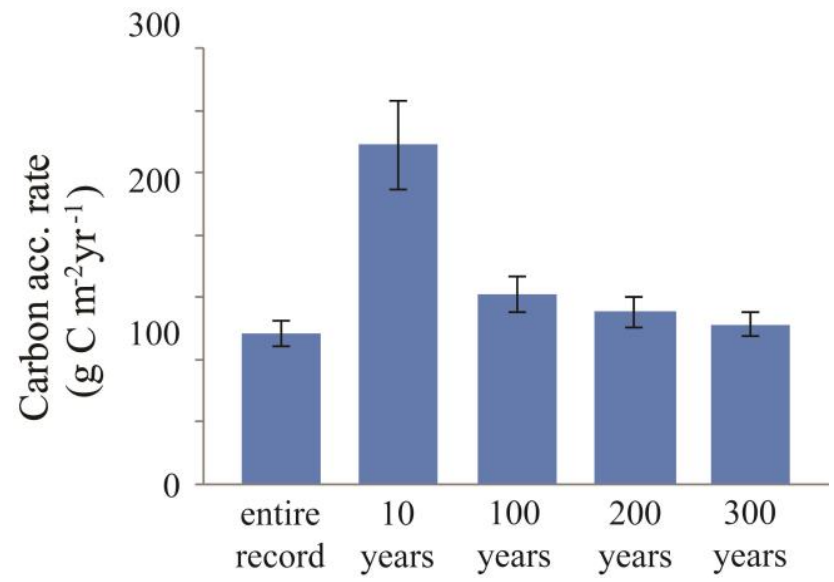

Fig. 4.6. Average $\mathrm{C}$ accumulation for SAL in different time slices. 
In SAL, the 100-year average CAR is similar to its average CAR for the entire measurement period (400 years; Fig. 4.6). It indicates that a 100 -year timeframe is appropriate to represent the CAR, particularly of lagoon ecosystems, on a longer time scale. Here, the 100-year CAR sequence is used to compare the SAL's C sequestration capacity to records from other mangrove-dominated lagoons that mostly cover the last 100 years (Fig. 4.7a).
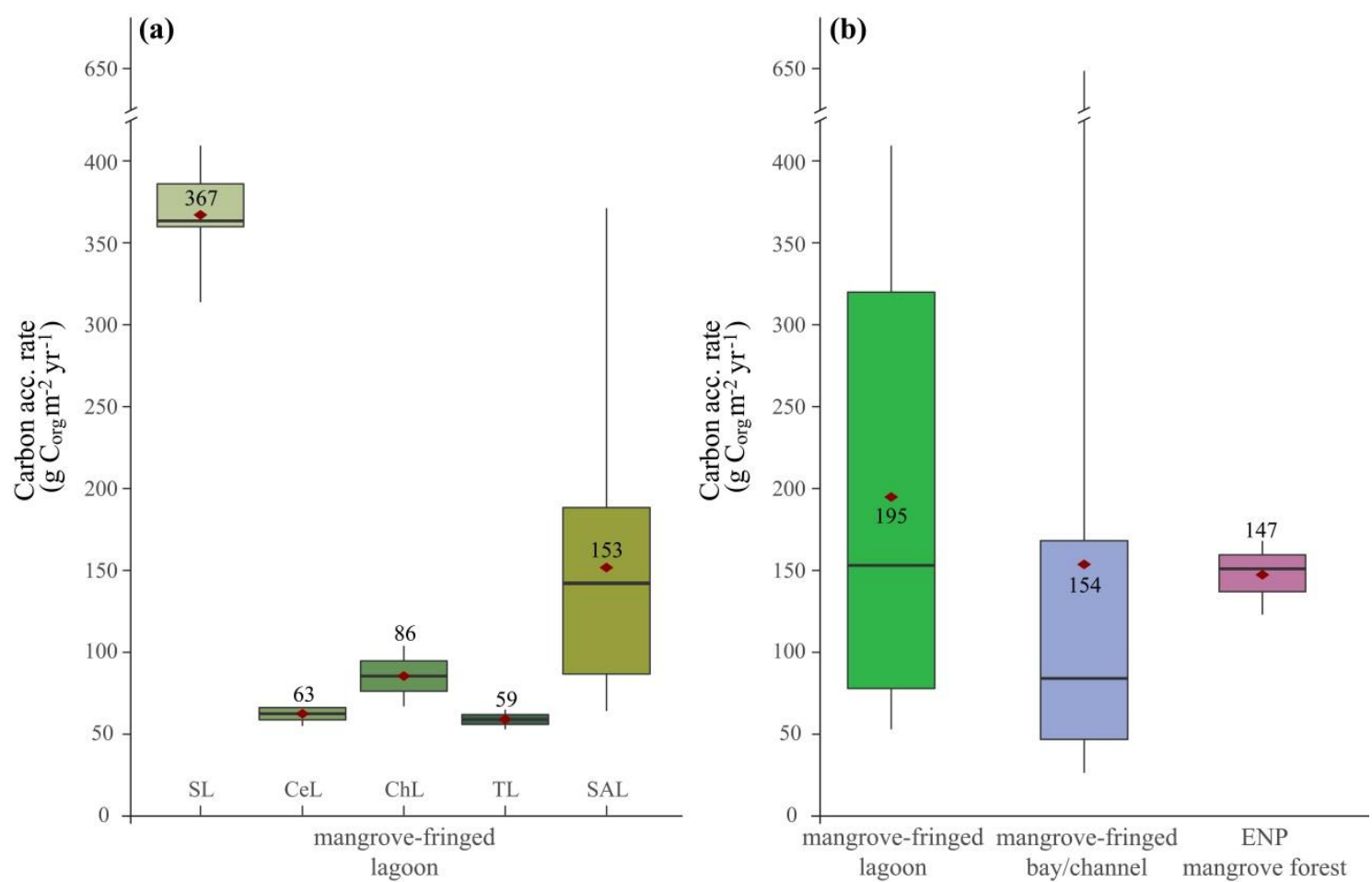

Fig. 4.7. Boxplot comparison of $\mathrm{C}$ accumulation rates during the last ca. 100 years of: a. mangrove-dominated lagoons; and b. mangrove-dominated coastal ecosystems (datasets included in the analysis are provided in Table 4.4). Red diamond symbols represent the average values. Site abbreviations: SL-Soledad Lagoon (Ruiz-Fernández et al., 2011), CeL-Celestun Lagoon, ChL-Chelem Lagoon, TL-Términos Lagoon (Gonneea et al., 2004), SAL-Segara Anakan Lagoon, ENP-Everglades National Park (Smoak et al., 2013; Breithaupt et al., 2014).

Compared to other mangrove-fringed lagoons such as the Celestun $(\mathrm{CeL})$, Chelem $(\mathrm{ChL})$ and Términos (TL) on the Yucatan Peninsula in Mexico, SAL accumulated 2-3 times more carbon during the last century (Fig. 4.7a). Owing to the karstic geological condition, lagoons on the Yucatan Peninsula receive little sediment through surface 
runoff or river input (Gonneea et al., 2004) and hence sedimentation rates and C accumulation rates are fairly low. Soledad Lagoon (SL) in Colombia, on the other hand, accumulated over two times more carbon than SAL during the last century (Fig. 4.7a). Based on its geomorphology, SL can be defined as a choked lagoon (Kjerfve, 1986) and it received river water input only occasionally (Ruiz-Fernández et al., 2011). SL has a long water residence time and restricted tidal or river energy influence. This can result in rapid biomass accumulation as well as in limited sediment resuspension and $\mathrm{C}$ export through tidal or river flushing (Kennish and Paerl, 2010).

The comparison also suggests that, in general, river-fed mangrove-fringed lagoons accumulate $\mathrm{C}$ more effectively than, for example, the mangrove forest of the Everglades National Park (ENP; Supplementary 4; Smoak et al., 2013; Breithaupt et al., 2014) and other mangrove-fringed ecosystems with little or no river input such as bays or channels during the last century (Fig. 4.7b). Sediment is transported to the coastal area mainly by river discharge (Wolanski, 1994). In a mangrove forest that is not under the influence of river input, sediment particles are distributed at high tide when the water spills over and inundates the forest (Kathiresan, 2003), in contrast to direct sediment delivery into lagoons, bays or channels. This explains the lower sediment supply and hence lower C accumulation in such a mangrove forest compared to other coastal ecosystems. Meanwhile, although channels and bays also receive high allochthonous sediment input from rivers and runoff, their geomorphological settings tend to be more exposed and less protected than lagoons (Brunskill et al., 2002). This makes them more prone to sediment redeposition due to wind/tidal energy and/or $\mathrm{C}$ export through tidal flushing (Brunskill et al., 2002), thus they accumulate C less effectively than lagoon ecosystems. 
Table 4.4. Datasets included in the comparison (Fig. 4.7b)

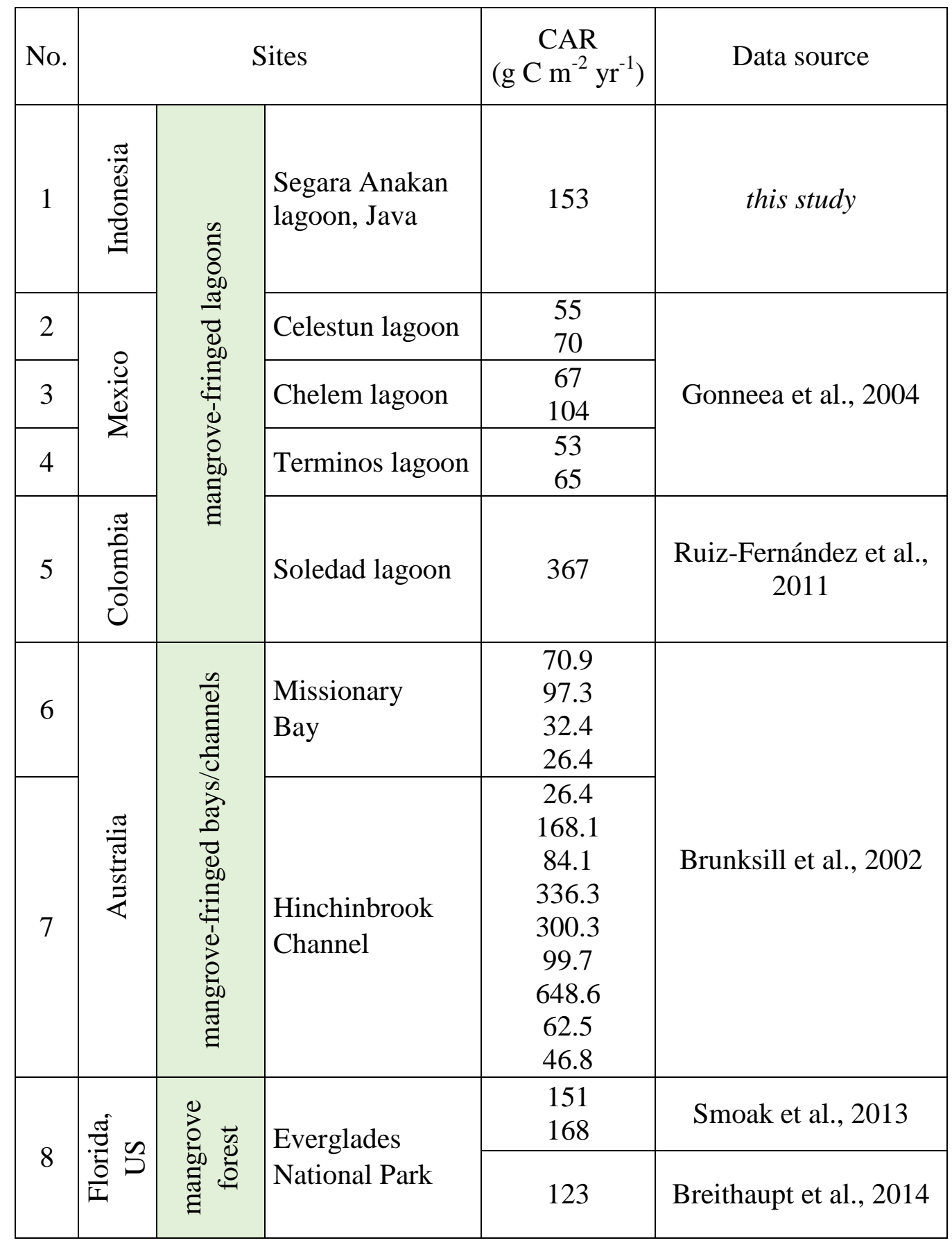

\subsection{Conclusion}

The Segara Anakan Lagoon's capacity to accumulate C, as its environmental condition, is highly dynamic and mainly governed by climatic conditions and human-induced landscape modification (Fig. 4.8). According to the palaeoecological information, 
during a drier climate in the past the CAR of SAL increased possibly due to reduced sediment dilution and accelerated OM accumulation through salt-induced flocculation. As a consequence, the predicted decrease of precipitation over Java in the future (Cruz et al., 2007; Qalbi et al., 2017) will likely increase the CAR of SAL as happened in the past.

Land use changes in the catchment and river modifications contributed to the increasing CAR in SAL through higher preservation rates due to increased sediment input into the ecosystem, although it also reduces the lagoon's size. If the trend of sediment input into the lagoon continues, the CAR of SAL will likely increase in the future. However, continuous logging of the surrounding mangrove forest, which is a major source of the sequestered $\mathrm{C}$, could result in a reduced CAR.

If deforestation and degradation of the mangrove forest in SAL continue, its $\mathrm{C}$ sink function will diminish. Thus, the coverage area and condition of the surrounding mangrove forest needs to be maintained or improved in order to sustain the $\mathrm{C}$ sequestration function of SAL. This is especially important due to the fact that, on a global scale, SAL is among the most effective mangrove-dominated lagoons in terms of C sequestration (Fig. 4.7a).

Meanwhile, among mangrove-dominated ecosystems, lagoons sequester C most effectively because they tend to receive a higher sediment input than other coastal ecosystems and are geomorphologically more protected (Fig. 4.7b). Following the urgency for the removal of atmospheric $\mathrm{CO}_{2}$ through natural sequestration, mangrovedominated lagoons are thus quantitatively important natural carbon sinks that are relevant in terms of global climate change mitigation. These ecosystems need to be prioritized for conservation and restoration. 


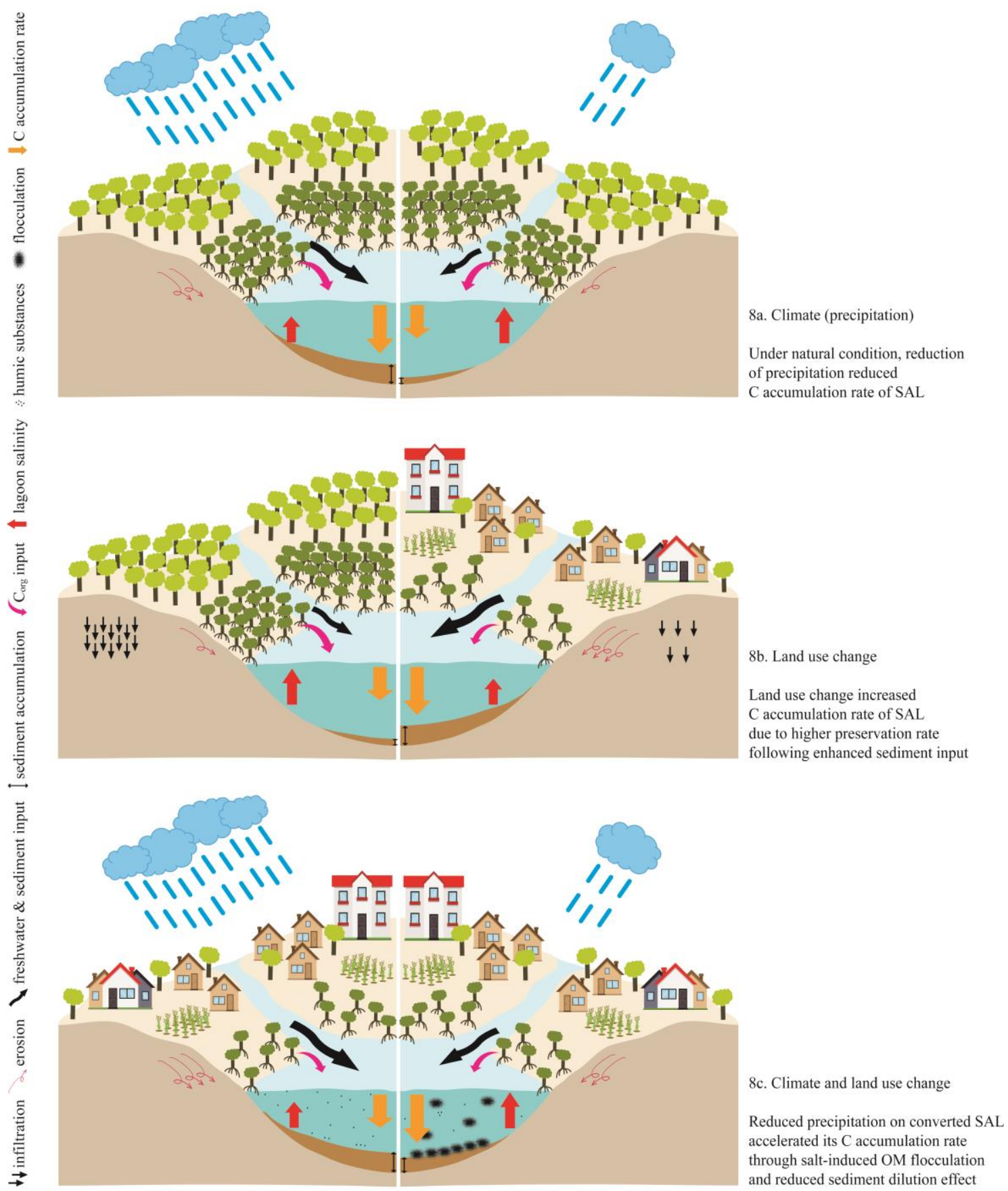

Fig. 4.8. Visualization of how climate and land use change governed the dynamics of environment and $\mathrm{C}$ accumulation in SAL during the last 400 years. The house vector arts were downloaded from www.freepik.com 


\section{Acknowledgement}

Financial support by the German Federal Ministry for Education and Research (Grant

No. 03F0644A) within the frame of the SPICE (Science for the Protection of Indonesian

Coastal Marine Ecosystems) program and Deutscher Akademischer Austauschdienst (DAAD) is gratefully acknowledged. The authors thank Dorothee Dasbach for laboratory assistance and Hanung Cahyorino, Lies Dewi, Yeni Astuti and Bayu Dwijaya for assistance during fieldwork.

\section{References}

Alongi D.M. (2012) Carbon sequestration in mangrove forests. Carbon Management, 3, 313-22.

Alongi D.M. (2015) The impact of climate change on mangrove forests. Current Climate Change Reports, 1, 30-39.

Anthony A., Atwood J., August P., Byron C., Cobb S., Foster C., Fry C., Gold A., Hagos K., Heffner L., Kellogg D.Q., Lellis-Dibble K., Opaluch J.J., Oviatt C., Pfeiffer-Herbert A., Rohr N., Smith L., Smythe T., Swift J., Vinhateiro N. (2009) Coastal lagoons and climate change: ecological and social ramifications in U.S. Atlantic and Gulf coast ecosystems. Ecology and Society, 14(1), 8.

Appleby P.G., Oldfield F. (1978) The calculation of lead-210 dates assuming a constant rate of supply of unsupported ${ }^{210} \mathrm{~Pb}$ to the sediment. Catena, $5(1), 1-8$.

Appleby P.G., Oldfield F. (1983) The assessment of Pb-210 data from sites with varying sediment accumulation rates. Hydrobiologia, 103, 29-35. doi:10.1007/BF00028424

Appleby P.G. (2008) Three decades of dating recent sediments by fallout radionuclides: a review. The Holocene, 18(1), 83-93.

Ardli E.R., Wolff M. (2009) Land use and land cover change affecting habitat distribution in the Segara Anakan lagoon, Java, Indonesia. Regional Environmental Change, 9, 235-243. doi:10.1007/s10113-008-0072-6.

Becking J.H. (1935) De ontwikkeling van de Dienst der wildhoutbosschen op Java gedurende de laatsche vijf Jaren. Tectona, 28, 343-433.

Boomgaard P. (2002) From subsistence crises to business cycle depressions, Indonesia 1800-1940. Conference on Economic Growth and Institutional Change in Indonesia in the 19th and 20th Centuries, Amsterdam, 25-26 February 2002

Boomgaard P., van Zanden J.L. (1990) Food crops and arable lands, Java 1815-1942. Changing economy in Indonesia. A selection of statistical source material from the early 19th century up to 1940, Volume 10. Amsterdam: The Royal Tropical Institute. 
BPS (Badan Pusat Statistic) Cilacap (2017) Kecamatan Kampung Laut Dalam Angka. https://cilacapkab.bps.go.id/publication/

Bradley R.S. (1999) Paleoclimatology: Reconstructing Climates of the Quaternary. International Geophysics, 68, 1-614.

Breithaupt J.L., Smoak J.M., Smith III T.J., Sanders C.J. (2014) Temporal variability of carbon and nutrient burial, sediment accretion, and mass accumulation over the past century in a carbonate platform mangrove forest of the Florida Everglades. Journal of Geophysical Research: Biogeosciences, 119, doi:10.1002/2014JG002715.

Brevik E.C., Homburg J.A. (2004) A 5000 year record of carbon sequestration from a coastal lagoon and wetland complex, Southern California, USA. Catena, 57, 221232. doi:10.1016/j.catena.2003.12.001.

Brunskill G.J., Zagorskis I., Pfitzner J. (2002) Carbon burial rates in sediments and a carbon mass balance for the Herbert River region of the Great Barrier Reef continental shelf, North Queensland, Australia. Estuarine, Coastal and Shelf Science, 54, 677-700. doi:10.1006/ecss.2001.0852.

Brush G.S., Brush L.M. (1972) Transport of pollen in a sediment-laden channel: a laboratory study. American Journal of Science, 272, 359-381.

Brush G.S. (1989) Rates and patterns of estuarine sediment accumulation. Limnology and Oceanography, 34(7), 1235-1246.

Burton W., Holman J., Lazonby J., Pillin, G., Waddington D. (2000) Salters Advanced Chemistry: Chemical Storylines (2nd ed.). Oxford, United Kingdom: Heinemann Educational Publisher.

Chmura G.L., Eisma D. (1995) A palynological study of surface and suspended sediments on a tidal flat: implications for pollen transport and deposition in coastal waters. Marine Geology, 128, 183-200.

Chmura G.L., Anisfield S.C., Cahoon D.C., Lynch J.C. (2003) Global carbon sequestration in tidal, saline wetland soils. Global Biogeochemical Cycles, 17(4), 1111. doi:10.1029/2002GB001917

Chowdhury R.R., Uchida E., Chen L., Osorio V., Yoder L. (2017) Chapter 9: Anthropogenic drivers of mangrove loss: geographic patterns and implications for livelihoods. In: V. Rivera-Monroy, S.Y. Lee, E. Kristensen \& R.R. Twilley (Eds.), Mangrove Ecosystems: A Global Biogeographic Perspective - Structure, Function and Services (pp. 275-300). New York: Springer Publishing Company.

Christen J.A. (1994) Summarizing a set of radiocarbon determinations: a robust approach. Applied Statistics-Journal of the Royal Statistical Society Series C, 43(3), 489-503.

Corlett R.T. (2015) The Anthropocene concept in ecology and conservation. Trends in Ecology \& Evolution, 30(1), 36-41. doi: 10.1016/j.tree.

Creutzberg P., van Laanen J.T.M. (1987) Sejarah statistic Ekonomi Indonesia. Yogyakarta, Indonesia: Yayasan Obor Indonesia. 
Croudace I.W., Rindby A., Rothwell R.G. (2006) ITRAX: description and evaluation of a new multi-function X-ray core scanner. In: R.G. Rothwell (Ed.), New Techniques in Sediment Core Analysis (pp. 51-63). London: Geological Society of London.

Cruz R.V., Harasawa H., Lal M., Wu S., Anokhin Y., Punsalmaa B., Honda Y., Jafari M., Li C., Huu Ninh N. (2007) Asia. In: M.L. Parry, O.F. Canziani, J.P. Palutikof, P.J. van der Linden, C.E. Hanson (Eds.), IPCC Fourth Assessment Report - Climate Change: Impacts, Adaptation and Vulnerability. Cambridge, United Kingdom: Cambridge University Press.

Dangendorf S., Marcos M., Wöppelmann G., Conrad C.P., Frederikse T., Riva R. (2017) Reassessment of 20th century global mean sea level rise. Proceedings of the National Academy of Sciences. doi:10.1073/pnas.1616007114.

De Haan J.H. (1931) Het een en ander over de Tjilat japsche Vloedbosschen. Tectona, 24, 39-76.

Diemont W.H., Smiet A.C., Nurdin (1991) Re-thinking erosion on Java. Netherland Journal of Agricultural Science, 39, 213-224.

Donato D.C., Kauffman J.B., Murdiyarso D., Kurnianto S., Stidham M., Kanninen M. (2011) Mangroves among the most carbon-rich forests in the tropics. Nature Geoscience, 4, 293-297. doi:10.1038/ngeo1123

Eong O.J. (1993) Mangroves - A carbon source and sink. Chemosphere, 27(6), 10971107.

Ezcurraa P., Ezcurra E., Garcillán P.P., Costa M.T., Aburto-Oropeza O. (2016) Coastal landforms and accumulation of mangrove peat increase carbon sequestration and storage. PNAS, 113(16), 4404-4409.

Faegri K., Iversen J. (1989) In: Textbook of Pollen Analysis, revised by K. Faegri, P.E. Kaland, K. Krzywinski. New York: John Wiley.

Fernando M.R. (2010) The worst of both worlds: Commercial rice production in West Indramayu, 1885-1935. Journal of Southeast Asian Studies, 41(3), 421-448. doi:10.1017/S0022463410000251

Fitriani A. (2012) Genetic variation of Pinus merkusii Jung rt de Vriese from natural forest of Aceh and seedling house of Jember measured using the isoenzyme method. Agroscientiae, 19, No. 3.

Franklin J., Serra-Diaz J.M., Syphard A.D., Regan H.M. (2016) Global change and terrestrial plant community dynamics. Proceedings of the National Academy of Sciences, 113(14), 3725-3734. doi:10.1073/pnas. 1519911113.

França M.C., Cohen M.L., Pessenda L.C., Rossetti D.F., Lorente F.L., Buso Junior A.A, Guimarães J.T., Friaes Y., Macario K. (2013) Mangrove vegetation changes on Holocene terraces of the Doce River, southeastern Brazil. Catena, 110, 59-69. http://dx.doi.org/10.1016/j.catena.2013.06.011.

Gastaldo R.A., Feng W. (1996) Palynofacies Patterns in Channel Deposits of the Rajang River and Delta, Sarawak, East Malaysia. Palaios, 11, 266-279. doi:10.2307/3515234 
Gastaldo R.A., Feng W. (2012) Taphonomic controls on the distribution of palynomorphs in tidally influenced coastal deltaic settings. Palaios, 27, 798-810. doi:10.2110/palo.2012.p12-030r

Giesen W., Wulffraat S., Zieren M., Scholten L. (2007) Mangrove guidebook for Southeast Asia. Bangkok, Thailand: Food and Agricultural Organisation and Wetlands International.

Gonneea M.E., Paytan A., Herrera-Silveira J.A. (2004) Tracing organic matter sources and carbon burial in mangrove sediments over the past 160 years. Estuarine, Coastal and Shelf Science, 61, 211e227. doi:10.1016/j.ecss.2004.04.015.

Goodbred S.L., Kuehl S.A. (1998) Floodplain processes in the Bengal Basin and the storage of Ganges-Brahmaputra river sediment: An accretion study using ${ }^{137} \mathrm{Cs}$ and ${ }^{210} \mathrm{~Pb}$ geochronology. Sedimentary Geology, 121(3-4), 239-258.

Goring S., Lacourse T., Pellatt M.G., Mathewes R.W. (2013) Pollen assemblage richness does not reflect regional plant species richness: a cautionary tale. Journal of Ecology, 101, 1137-1145. doi: 10.1111/1365-2745.12135

Grimm E.C. (1987) CONISS: A FORTRAN 77 program for stratigraphically constrained cluster analysis by the method of incremental sum of squares. Computers \& Geosciences, 13, 13-35.

Griscom B.W., Adams J., Ellis P.W., Houghton R.A., Lomax G., Miteva D.A., Schlesinger W.H., Schoh D., et al. (2017) Natural climate solution. PNAS, 114, 11645-11650.

Haenssler E., Unkel I., Dörfler W., Nadeau M.J. (2014) Driving mechanisms of Holocene lagoon development and barrier accretion in Northern Elis, Peloponnese, inferred from the sedimentary record of the Kotychi Lagoon. E\&G Quaternary Science Journal, 63(1), 60-77. doi:10.3285/eg.63.1.04

Hahn A., Kliem P., Oehlerich M., Ohlendorf C., Zolitschka B. (2014) Elemental composition of the Laguna Potrok Aike sediment sequence reveals paleoclimatic changes over the past $51 \mathrm{ka}$ in southern Patagonia, Argentina. Journal of Paleolimnology, 52, 349-366. doi:10.1007/s10933-014-9798-y.

Herayati Y., Masnia N., Haryanti T. (1993) Makanan: Wujud, Variasi dan Fungsinya Serta Cara Penyajiannya Pada Orang Sunda di Jawa Barat. Jakarta, Indonesia: Departemen Pendidikan dan Kebudayaan, Direktorat Jenderal Kebudayaan.

Heyde J.J. (2016) Environmental governance and resource tenure in times of change: Experience from Indonesia. Ph.D Thesis. Bremen, Germany: University of Bremen.

Hinrichs S., Nordhaus I., Geist S.J. (2009) Status, diversity and distribution patterns of mangrove vegetation in the Segara Anakan lagoon, Java, Indonesia. Regional Environmental Change, 9, 275-289. doi:10.1007/s10113-008-0074-4

Hogg A.G., Hua Q., Blackwell P.G., Niu M., Buck C.E., Guilderson T.P., Heaton T.J., Palmer J.G., Reimer P.J., Reimer R.W., Turney C.S.M., Zimmerman S.R.H. (2013) SHCal13 Southern Hemisphere calibration, 0-50,000 years cal BP. Radiocarbon, 55(4), 1889-1903. doi: 10.2458/azu_js_rc.55.16783 
Holtermann P., Burchard H., Jennerjahn T. (2009) Hydrodynamics of the Segara Anakan lagoon. Regional Environmental Change, 9, 245-258. doi:10.1007/s10113008-0075-3

Hua Q., Barbetti M., Rakowski A.J. (2013) Atmospheric Radiocarbon for the Period 1950-2010. Radiocarbon, 55(4), 2059-2072.doi:10.2458/azu_js_rc.v55i2.16177

Huber D.J., Gulledge J. (2011) Extreme weather and climate change: understanding the link and managing the risk. Science and Impacts Program. Arlington: Center for Climate and Energy Solutions.

Irwansyah E. (2010) Analisa spasial perubahan penggunaan tanah di sekitar laguna Segara Anakan Kabupaten Cilacap - Provinsi Jawa Tengah. Globë, 12(1), 21 - 27.

Jennerjahn T.C., Ittekot V. (2002) Relevance of mangroves for the production and deposition of organic matter along tropical continental margins. Naturwissenschaften, 89, 23-30.

Jennerjahn T.C., Yuwono E. (2009) Segara Anakan, Java, Indonesia, a mangrovefringed coastal lagoon affected by human activities. Regional Environmental Change, 9, 231-233. doi:10.1007/s10113-009-0089-5.

Jennerjahn T.C., Gilman E., Krauss K.W., Lacerda L.D., Nordhaus I., Wolanski E. (2017) Chapter 7: Mangrove ecosystems under climate change. In: V. RiveraMonroy, S.Y. Lee, E. Kristensen \& R.R. Twilley (Eds.), Mangrove Ecosystems: A Global Biogeographic Perspective - Structure, Function and Services (pp. 211-244). New York: Springer Publishing Company.

Kathiresan K. (2003) How do mangrove forests induce sedimentation? Revista de Biologia Tropical, 51(2), 355-360.

Kennish M.J., Paerl H.W. (2010) Coastal Lagoons: Critical Habitats of Environmental Change. Florida, USA: CRC Press, Taylor and Francis Group.

Kida M., Tomotsune M., Iimura Y., Kinjo K., Ohtsuka T., Fujitake N. (2017) High salinity leads to accumulation of soil organic carbon in mangrove soil. Chemosphere, 177, 51-55. http://dx.doi.org/10.1016/j.chemosphere.2017.02.074

Kjerfve B. (1994) Coastal Lagoon Processes. Amsterdam, The Netherlands: Elsevier Science Ltd.

Konecky B.L., Russell J.M., Rodysill J.R., Vuille M., Bijaksana S., Huang Y. (2013) Intensification of southwestern Indonesian rainfall over the past millennium. Geophysical Research Letters, 40, 386-391. doi:10.1029/2012GL054331.

Li Z., Saito Y., Mao L., Tamura T., Li Z., Song B., Zhang Y., Lu A., Sieng S., Li J. (2012) Mid-Holocene mangrove succession and its response to sea-level change in the upper Mekong River delta, Cambodia. Quaternary Research, 78, 386-399. doi:10.1016/j.yqres.2012.07.001.

Lovelock C.E. (2008) Soil respiration and belowground carbon allocation in mangrove forests. Ecosystems, 11, 342-354. doi:10.1007/s10021-008-9125-4.

Lubis A.A. (2006) Constant rate of supply (CRS) model for determining the sediment accumulation rates in the coastal area using ${ }^{210} \mathrm{~Pb}$. Journal of Coastal Development, 10(1), 9-18. 
Lukas M.C. (2014a) Cartographic Reconstruction of Historical Environmental Change. Cartographic Perspectives, 78, 5-24. doi: 10.14714/CP78.1218.

Lukas M.C. (2014b) Eroding battlefields: Land degradation in Java reconsidered. Geoforum, 56, 87-100. doi: 10.1016/j.geoforum.2014.06.010.

Lukas M.C. (2015) Neglected treasures. Linking historical cartography with environmental changes in Java, Indonesia. Cartographica, 50, 141-162. doi:10.3138/cart.50.3.2891

Lukas M.C. (2017) Widening the scope: linking coastal sedimentation with watershed dynamics in Java, Indonesia. Regional Environmental Change, 17, 901-914. doi:10.1007/s10113-016-1058-4

Macreadie P.I., Rolph T.C., Boyd R., Schröder-Adams C.J., Skilbeck C.G. (2015) Do ENSO and coastal development enhance coastal burial of terrestrial carbon? PLoS ONE, 10(12), e0145136. doi:10.1371/journal.pone.0145136

Mao L., Batten D.J., Fujiki T., Li Z., Dai L., Wenig C. (2012) Key to mangrove pollen and spores of southern China: an aid to palynological interpretation of Quaternary deposits in the South China Sea. Review of Palaeobotany and Palynology, 176-177, 41-67. doi:10.1016/j.revpalbo.2012.03.004.

Marchio D.A., Savarese M., Bovard B., Mitsch W.J. (2016) Carbon sequestration and sedimentation in mangrove swamps influenced by hydrogeomorphic conditions and urbanization in Southwest Florida. Forests, 7, 116. doi:10.3390/f7060116.

Marzeion B., Cogley J.G., Richter K., Parkes D. (2014) Attribution of global glacier mass loss to anthropogenic and natural causes. Science, 345(6199), 919-921. doi: $10.1126 /$ science. 1254702

Meyers P.A. (1994) Preservation of elemental and isotopic source identification of sedimentary organic matter. Chemical Geology, 114, 289-302. doi:10.1016/00092541(94)90059-0

Mildenhall D.C., Brown L.J. (1987) An early Holocene occurrence of the mangrove Avicennia marina in Poverty Bay, North Island, New Zealand: its climatic and geological implications. New Zealand Journal of Botany, 25(2), 281-294. doi:10.1080/0028825X.1987.10410075

Mohtadi M., Oppo D.W., Steinke S., Stuut J.W., De Pol-Holz R., Hebbeln D., Lückge A. (2011) Glacial to Holocene swings of the Australian-Indonesian monsoon. Nature Geoscience, 4. doi:10.1038/NGEO1209.

Muhzin M.Z. (2008) Terbentuknya Keresidenan Priangan. Bandung, Indonesia: Program Pascasarjana Fakultas Sastra BKU Ilmu Sejarah Universitas Padjadjaran.

Mulyadi S. (2013) Kisah Pergulatan Peradaban Suku Pejagan Dalam Sejarah Ingatan Sesepuh Kampung Laut. Cilacap, Indonesia: Yayasan Sosial Bina Sejahtera Cilacap (YSBS).

Murdiyarso D., Donato D., Kauffman J.B., Kurnianto S., Stidham M., Kanninen M. (2009) Carbon storage in mangrove and peatland ecosystems. Working Paper, 48. Bogor, Indonesia: Center for International Forestry Research (CIFOR). 
Ni J., Yu G., Harrison S.P., Prentice C. (2010) Palaeovegetation in China during the late Quaternary: Biome reconstructions based on a global scheme of plant functional types. Palaeogeography, Palaeoclimatology, Palaeoecology, 289, 44-61 doi:10.1016/j.palaeo.2010.02.008

Noegrahati S., Narsito (2007) Integrated water monitoring to support the management of healthy Segara Anakan estuary. Jurnal Manusia dan Lingkungan, 14(1), 35-45.

Nolan C., Overpeck J.T., Allen J.R.M., Anderson P.M., Betancourt, J.L., Binney H.A., Brewer S., Bush M.B., et al. (2018) Past and future global transformation of terrestrial ecosystems under climate change. Science, 361(6405), 920-923. doi: 10.1126/science.aan5360.

Olive C.A. (1998) Land use change and sustainable development in Segara Anakan, Java, Indonesia: Interactions Among Society, Environment and Development. Thesis. Ontario, Canada: University of Waterloo.

Ometto J.P., Ehleringer J.R., Domingues T.F., Berry J.A., Ishida F.Y., Mazzi E., Higuchi N., Flanagan L.B., Nardoto G.B., Martinelli L.A. (2006) The stable carbon and nitrogen isotopic composition of vegetation in tropical forests of the Amazon Basin, Brazil. Biogeochemistry, 79 (1-2), 251-274.

Ouyang X., Lee S.Y., Connolly R.M. (2017) The role of root decomposition in global mangrove and saltmarsh carbon budgets. Earth-Science Reviews, 166, 53-63. http://dx.doi.org/10.1016/j.earscirev.2017.01.004.

Peluso N.P. (1992) Rich forests, poor people. Resource control and resistance in Java. Berkely and Los Angeles: University of California Press.

Perum Perhutani (2016) Statistik Perum Perhutani, Tahun 2011-2015. Jakarta: Perum Perhutani Kantor Pusat.

Poliakova A., Behling H. (2016) Pollen and fern spores recorded in recent and late Holocene marine sediments from the Indian Ocean and Java Sea in Indonesia. Quaternary International, 392, 251-314.

Purba M. (1991) Impact of high sedimentation rates on the coastal resources of Segara Anakan, Indonesia. In: L.M. Chou, T.E. Chua, H.W. Khoo, P.E. Lim, J.N. Paw, G.T. Silvestre, M.J. Valencia, A.T. White \& P.K. Wong (Eds.), Towards an Integrated management of tropical coastal resources (pp. 143-152). ICLARM Conference Proceedings 22, National University of Singapore, Singapore and International Center for Living Aquatic Resources Management, Philippines.

Purwanto B. (2002) Peasant economy and institutional changes in late colonial Indonesia. In: International Conference on Economic Growth and Institutional Change in Indonesia in the $19^{\text {th }}$ and $20^{\text {th }}$ Centuries, Amsterdam 25-26 February 2002.

Qian J., Robertson A.W., Moron V. (2010) Interactions among ENSO, the Monsoon, and Diurnal Cycle in Rainfall Variability over Java, Indonesia. Journal of the Atmospheric Sciences, 67, 3509-3524. doi:10.1175/2010JAS3348.1

Quamar M.F., Bera S.K. (2014) Pollen production and depositional behaviour of teak (Tectona grandis Linn. F.) and sal (Shorea robusta Gaertn. F.) in tropical deciduous 
forests of Madhya Pradesh, India: An overview. Quaternary International, 325, 111e115 http://dx.doi.org/10.1016/j.quaint.2013.07.040

Ramsey C.B., (2009) Bayesian analysis for radiocarbon dates. Radiocarbon, 51(1), 337360.

Rau G.H., Greene C.H. (2015) Emission reduction is not enough. Science, 349(6255), 1459.

Raupach M.R., Canadell J.G. (2010) Carbon and the Anthropocene. Current Opinion in Environmental Sustainability, 2, 210-218. doi:10.1016/j.cosust.2010.04.003

Reitz E., Shackley M. (2012) Environmental Archaeology. New York: Springer.

Richards D.R., Friess D.A. (2016) Rates and drivers of mangrove deforestation in Southeast Asia, 2000-2012. Proceedings of the National Academy of Sciences, 113, 344-349.

Roberts J., Jackson N, Smith M. (2006) Tree Roots in the Built Environment. London, United Kingdom: The Stationary Office (TSO).

Rodelli M.R., Gearing J.N., Gearing P.J., Marshall N., Sasekumar A. (1984) Stable isotope ratio as a tracer of mangrove carbon in Malaysian ecosystems. Oecologia, $61,326-333$.

Ruiz-Fernández A.C., Marrugo-Negrete J.L., Paternina-Uribe R., Pérez-Bernal L.H. (2011) ${ }^{210} \mathrm{~Pb}$-derived Sedimentation Rates and $\mathrm{C}_{\text {org }}$ Fluxes in Soledad Lagoon (Cispatá Lagoon System, NW Caribbean Coast of Colombia). Estuaries and Coasts, 34, 1117-1128. doi:10.1007/s12237-011-9394-6.

Sanders C.J., Eyre1 B.D., Santos I.R., Machado W., Luiz-Silva W., Smoak J.M., Breithaupt J.L., Ketterer M.E., Sanders L., Marotta H., Silva-Filho E. (2014) Elevated rates of organic carbon, nitrogen, and phosphorus accumulation in a highly impacted mangrove wetland. Geophysical Research Letter, 41, 2475-2480. doi:10.1002/2014GL059789.

Sapkota P. (2017) Sustainable Riverine Flood Risk Management Potential Techniques and Challenges. Helsinki, Finland: Metropolia University of Applied Sciences.

Schwarzbauer J., Jovančićević B. (2015) Fundamentals in Organic Geochemistry. Cham, Switzerland: Springer.

Schwerdtner Máñez K.S. (2010) Java's forgotten pearls: the history and disappearance of pearl fishing in the Segara Anakan lagoon, South Java, Indonesia. Journal of Historical Geography, 36, 367-376. doi:10.1016/j.jhg.2010.03.004.

Setyawan A.D., Winarno K. (2006) Pemanfaatan langsung ekosistem mangrove di Jawa Tengah dan penggunaan lahan di sekitarnya; kerusakan dan upaya restorasinya. Biodiversitas, 7, 282-291. doi:10.13057/biodiv/d070318

Shamlou P.A. (1993) Processing of Solid-Liquid Suspensions. Oxford, United Kingdom: Butterworth-Heinemann Ltd.

Silva E.I.L., Katupotha J., Amarasinghe O., Manthrithilake H., Ariyaratna R. (2013) Lagoons of Sri Lanka: from the origins to the present. Colombo, Sri Lanka: International Water Management Institute. (IWMI). doi:10.5337/2013.215 
Smiet A.C. (1990) Forest ecology on Java: conversion and usage in a historical perspective. Journal of Tropical Forest Science, 2(4), 286 - 302.

Smoak J., Breithaupt III J., Smith T., Sanders C. (2013) Sediment accretion and organic carbon burial relative to sea-level rise and storm events in two mangrove forests in Everglades National Park, Catena, 104, 58-66, doi:10.1016/j.catena.2012.10.009.

Somasundaran P. (2006) Encyclopedia of Surface and Colloid Science, Band 4. Boca Raton - Florida, United States: CRC Press, Taylor and Francis Group.

Sosef M.S.M, Hong L.T., Prawirohatmodjo S. (1998) Plant Resources of South-East Asia No. 5(3). Timber trees: Lesser-known timbers. Bogor, Indonesia: Prosea Foundation.

Steinke S., Mohtadi M., Prange M., Varma V., Pittauerova D., Fischer H.W. (2014) Mid- to Late-Holocene AustralianeIndonesian summer monsoon variability. Quaternary Science Reviews, 93, 142e154. http://dx.doi.org/10.1016/j.quascirev.2014.04.006

Sutherland B.R., Barrett K.J., Gingras M.K. (2014) Clay settling in fresh and salt water. Environ Fluid Mechanics, 15(1), 147-160. doi:10.1007/s10652-014-9365-0

Twiddle C.L., Jones R.T., Caseldine C.J., Sugita S. (2012) Pollen productivity estimates for a pine woodland in eastern Scotland: The influence of sampling design and vegetation patterning. Review of Palaeobotany and Palynology, 174, 67-68. https://doi.org/10.1016/j.revpalbo.2011.12.006

Twilley R. R., Chen R. H., Hargis T. (1992) Carbon sinks in mangrove forests and their implications to the carbon budget of tropical coastal ecosystems, Water, Air and Soil Pollution, 64, 265-288.

Tyson R. (2001) Sedimentation rate, dilution, preservation and total organic carbon: Some results of a modelling study. Organic Geochemistry, 32(2), 333-339. doi:10.1016/S0146-6380(00)00161-3

UNFCCC - United Nation Framework Convention on Climate Change (2015) Adoption of the Paris Agreement. http://climateaction.unfccc.int/

Valiela I, Bowen J.L., York J.K. (2001) Mangrove forests: one of the world's threatened major tropical environments. BioScience, 51, 807-815.

van der Eng P. (2008) Food supply in Java during war and decolonisation, 1940-1950. Munich Personal RePEc Archive Paper 8852, 25.

van der Eng P. (2010) The sources of long-term economic growth in Indonesia, 18802008. Explorations in Economic History, 47, 294-309.

Wang L., Mu M., Li X., Lin P., Wang W. (2011) Differentiation between true mangroves and mangrove associates based on leaf traits and salt contents. Journal of Plant Ecology, 4(4), 292-301. doi:10.1093/jpe/rtq008

Waryono T. (2002) The History and Social Value Characteristics of Kampung Laut Segara Anakan Cilacap Community. Kumpulan Makalah Periode 1987-2008. Indonesia.

Weiss C., Weiss J., Boy J., Iskandar I., Mikutta R., Guggenberger G. (2016) Soil organic carbon stocks in estuarine and marine mangrove ecosystems are driven by 
nutrient colimitation of $\mathrm{P}$ and N. Ecology and Evolution, 6(14), 5043-5056. doi:10.1002/ece3.2258

Wheeler T., von Braun J. (2013) Climate change impact on global food security. Science, 341(6145), 508-513. doi: 10.1126/science. 1239402

White A.T., Martosubroto P., Sadorra M.S.M. (1989) The coastal environmental profile of Segara Anakan-Cilacap, South Java, Indonesia. ICLARM technical reports on coastal area management series no. 25, International Centre for Living Aquatic Resources Management. Manila, Philippines.

Wolanski E. (1994) Physical oceanography processes of the Great Barrier Reef. Boca Raton - Florida, United States: CRC Press, Taylor and Francis Group.

Wright Jr. H.E., (1967) A square-rod piston sampler for lake sediments. Journal of Sedimentary and Petrology, 37(3): 975-976.

Yuwono E., Jennerjahn T., Nordhaus I., Ardli E.R., Sastranegara M.H., Pribadi R. (2007) Ecological status of Segara Anakan, Indonesia: a mangrove-fringed Lagoon affected by human activities. Asian Journal of Water, Environmental and Pollution, 4(1), 61-70. 


\section{Supplementary 1}

Complete list of plant taxa identified from pollen and spore analyses

Mangrove and mangrove associate (MMA)

\section{Plant family}

Acanthaceae

Apocynaceae

Arecaceae

Casuarinaceae

Combretaceae

Euphorbiaceae

Lecythidaceae

Leguminosae
Aquifoliaceae

Aizoaceae

Araceae

Arecaceae

Amaryllidoideae

Anacardiaceae

Apocynaceae

Begoniaceae

Campanulaceae

Cannabaceae

Capparaceae

Convolvulaceae

Cyperaceae

Escalloniaceae

Fabaceae

Fagaceae

Nenga
Pollen taxon

Acanthus

Avicennia

Cerbera

Nypa

Oncospermae

Ilex

Casuarina

Combretaceae-type

Lumnitzera

Blumeodendron

Excoecaria

Barringtonia

Derris

\section{Pollen taxon}

Sesuvium

Areca

Arecaceae type

Arenga

Calamus

Pinanga

Crinum

Alstonia

Capparis

Polyosma

Castanopsis
Plant family

Lythraceae

Meliaceae

Mimosaceae

Moraceae-Urticaceae

Pandanaceae

Phyllanthaceae

Primulaceae

Rhizophoraceae

Rubiaceae

Plant family

Leguminosae

Liliaceae

Pollen taxon

Sonneratia alba

S. caseolaris

S. apetala

S. ovata

Xylocarpus

Ficus

Pandanus

Glochidion

Aegiceras

Bruguiera

Ceriops

Rhizophora

Ixora

\section{Pollen taxon}

Acacia-type

Melastomataceae

Meliaceae

Aglaia

Meliaceae-type

Moraceae-Urticaceae

Myrsinaceae Myrtaceae

Musaceae

Nymphaeaceae

Nuphar

Oleaceae

Paracryphiaceae

Quintinia

Pinaceae

Pinus

Podocarpaceae

Dacrycarpus

Dacrydium

Podocarpus

Rutaceae

Rubiaceae

Sapindaceae
Nauclea

Psychotria Randia

Acer-type

Pometia 


$\begin{array}{llll} & \text { Fagaceae-type } & \text { Sapotaceae } & \\ & \text { Lithocarpus } & \text { Stemonuraceae } & \text { Stemonurus } \\ \text { Gnetaceae } & \text { Gnetum } & \text { Vitaceae } & \end{array}$

Open vegetation $(\mathrm{OV})$

\section{Plant family}

Amaranthaceae

Asteraceae

Bignoniaceae

Cornaceae

Dasticaceae

Ericaceae

\section{Staple Agriculture (SA)}

Plant family

Araceae

Arecaceae

Droseraceae

Nymphaeaceae

Onagraceae
Pollen taxon

Colocasia

Cocos

Nymphaea

Ludwigia
Plant family

Lamiaceae

Leguminosae

Malvaceae

Poaceae

Rubiaceae

Tiliaceae

\section{Pollen taxon}

Bauhinia

Spermacoce

Plant family

Pollen taxon

Oxalidaceae

Oxalis

Poaceae

Oryza-type

Rutaceae

Citrus

Zanthoxylum
Solanaceae

\section{Spores}

\section{Plant family}

Spore taxon

Monolete spores

Trilete spores 


\section{Supplementary 2}

Cluster analysis result of pollen and spore data

Ecludian Distance

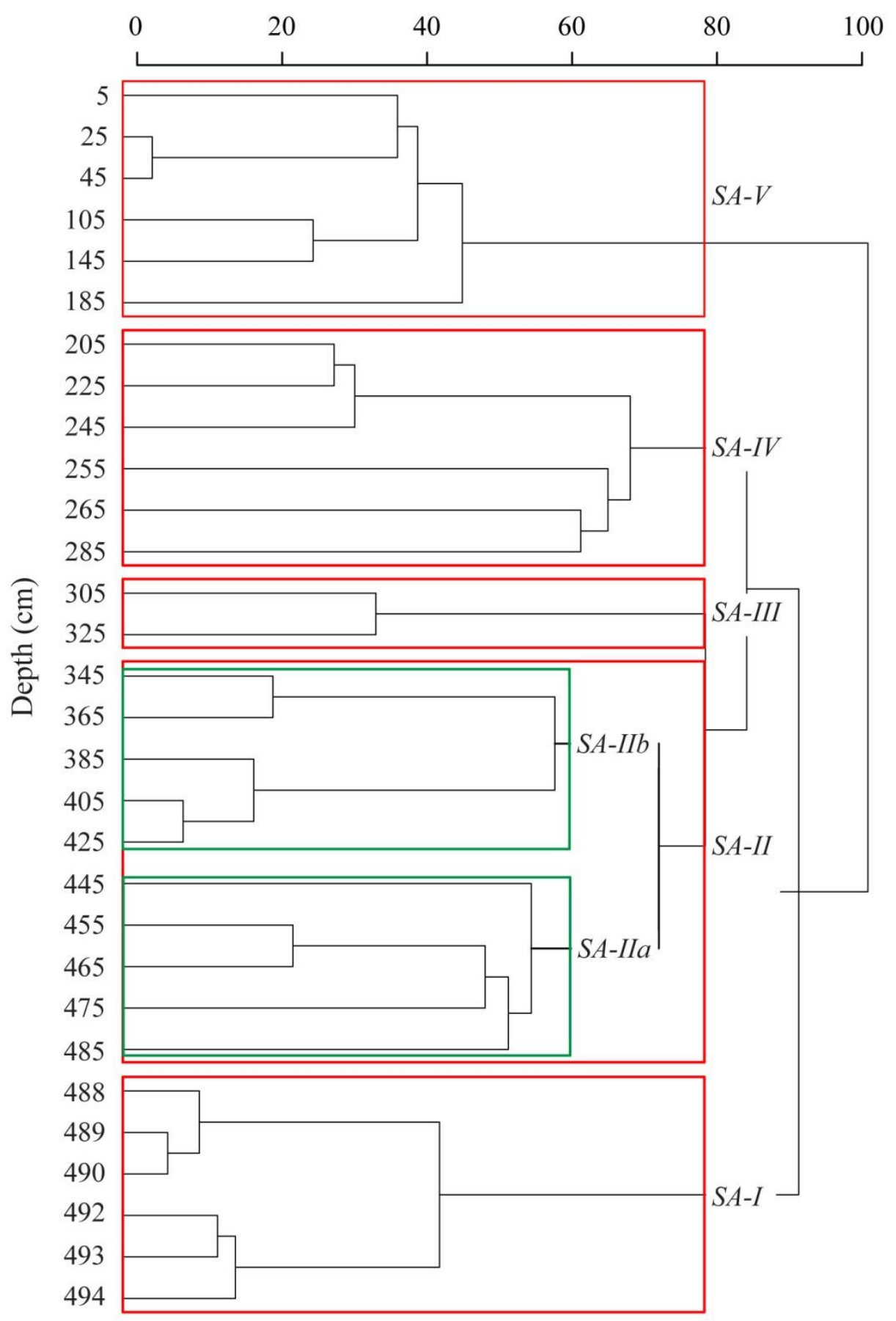




\section{Supplementary 3}

Diagram of total pollen influx and pollen concentrations of Segara Anakan Lagoon. Only the concentration of taxa that are shown in main text Fig. 4.3 are presented here.
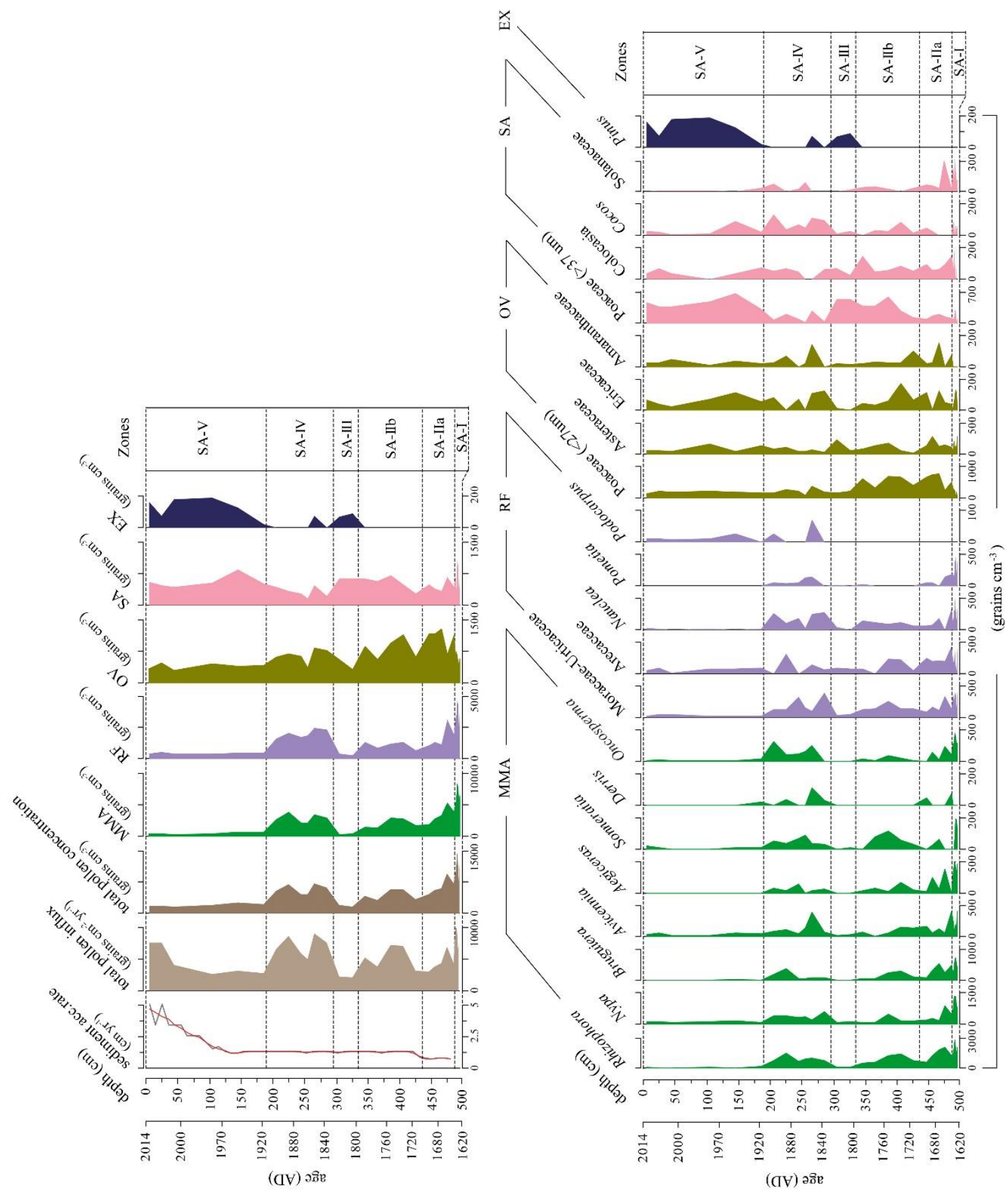


\section{Chapter 5}

\section{Synthesize}

This research contributes to an enhanced ecological understanding of Indonesian coastal wetlands by providing insights on the environmental processes and controlling factors of the dynamics of the ecosystems and their $\mathrm{C}$ sequestration capacities. The significance of the ecosystems' $\mathrm{C}$ sequestration capacities and their potential for global climate change mitigation is also underlined here. The resilience of the ecosystems to both natural and anthropogenic disturbances is also assessed. Altogether, the outcomes of this research help improving the effectiveness and efficiency of Indonesian coastal wetlands conservation, management and restoration.

\subsection{Environmental and $C$ accumulation dynamics of coastal wetlands in Indonesia}

Indonesian coastal wetlands are very dynamics ecosystems that are mainly influenced by sea level changes, climatic variabilities and human activities. These factors affect the ecosystems by changing their hydrological conditions and vegetation composition. The impacts of these factors are, however, can be site-specific. For instance, the occurrence of ENSO-related drought in the late Holocene that caused little impact in vegetation and hydrological condition of Sungai Buluh peatland resulted in forest burning and vegetation change in Kalampangan peatland, Borneo (Yulianto and Hirakawa, 2006). Meanwhile the $19^{\text {th }}$-century dryer climatic condition of Java has increased salinity of Segara Anakn Lagoon (SAL) that changed the taphonomic process of the lagoon. 
Similar to their environmental conditions, the ecosystem capacities of Indonesian coastal wetlands to store $\mathrm{C}$ are also dynamics. The variation in $\mathrm{C}$ accumulation of these ecosystems is closely related to the changes in environments hence controlled by similar driving factors. Consistent with their site-specific impacts on the environments, the influence of these factors to the $\mathrm{C}$ accumulation capacities of the coastal wetlands can also be unique and distinct in different sites. Human activities, for example, decreased the $\mathrm{C}$ accumulation rate in Sungai Buluh by changing the vegetation composition that negatively affect both ecosystem productivity and litter quality. Contrarily, it enhanced the $\mathrm{C}$ accumulation in SAL by increasing sediment input into the lagoon that fuels $\mathrm{C}$ burial.

Generalization on the factors and ecosystem processes of coastal wetlands in Indonesia thus can be misleading. Identification of the site-specific processes and driving factors in addition to their potential unique consequences on the coastal wetland environments and their $\mathrm{C}$ sequestration functions is therefore important. This is particularly necessary in determining the future fate of the ecosystems in response to the global environmental changes such as warming climate or SLR (Webb et al., 2013).

\subsection{Potential of Indonesian coastal wetlands for climate change mitigation}

In term of belowground $\mathrm{C}$ sequestration, the potential of Indonesian coastal wetlands in the global $\mathrm{C}$ storage in comparison with other tropical coastal wetlands seems modest (Fig. 5.1). However, this comparison should be interpreted cautiously for two reasons. First, the global data can only include mangrove dominated ecosystems owing to the lack of CAR data from coastal peatlands in other tropical regions (Appendix I.a). Second, it cannot include Africa due to a remarkable lack of CAR data from African tropical coastal wetlands. 
Compared to other similar ecosystems globally, Indonesian mangrove dominated ecosystem has high $\mathrm{C}$ accumulation capacity (Fig. 5.1). However, as it is only represented by a single site in this comparison (Appendix I.a), the underlying cause of its higher $\mathrm{C}$ accumulation rate amongst other global mangrove dominated ecosystems is difficult to define. We hypothesize that it is due to a higher input of sediment into the ecosystem.

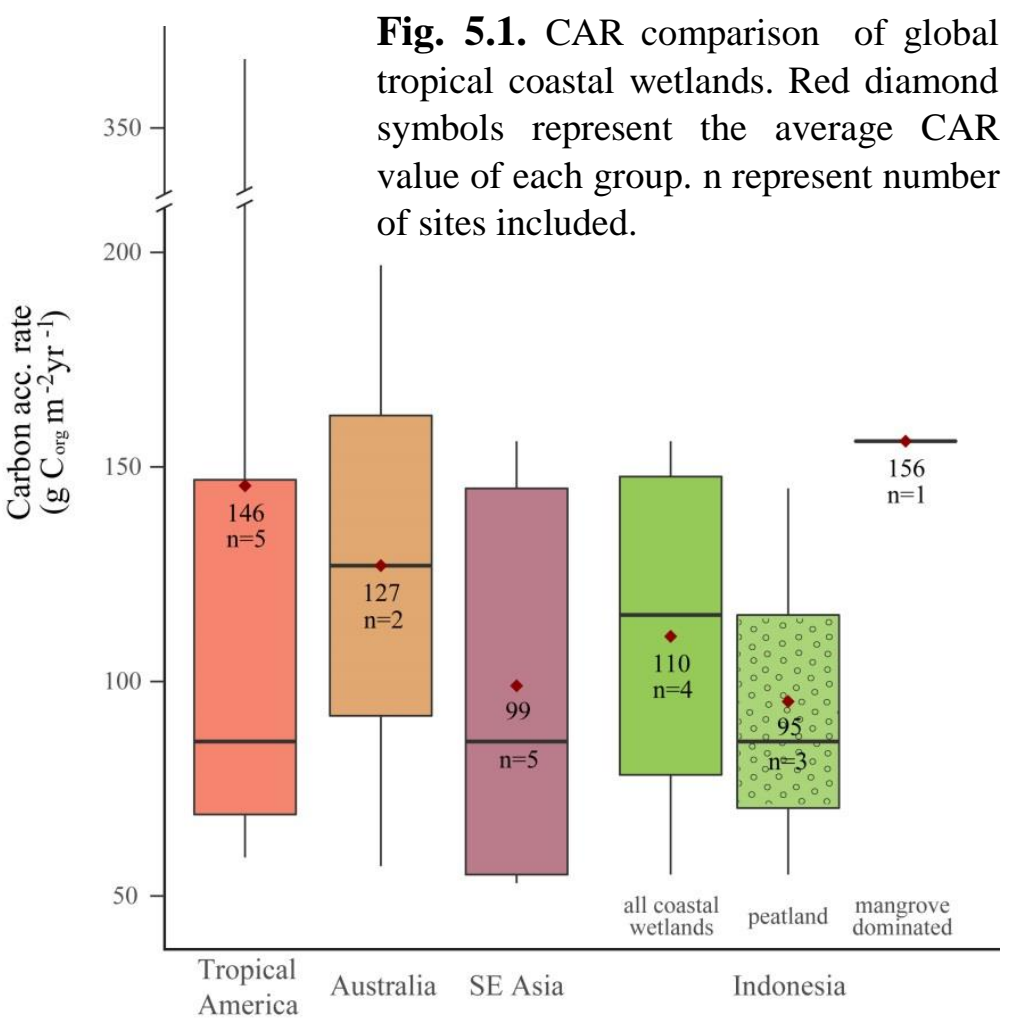

In Indonesia, mangrove dominated ecosystem also sequesters $\mathrm{C}$ faster than the coastal peatlands. This is conceivably due to higher allochtonous sediment input into mangrove dominated ecosystems that promotes faster sediment accretion and $\mathrm{OM}$ hence $\mathrm{C}$ burial (Sanders et al., 2014).

The peat and $\mathrm{C}$ accretions on peatlands, on the other hand, rely almost exclusively on the autochthonous OM production (Wüst et al., 2003).

This comparison however should also be interpreted cautiously because of the difference temporal length of the datasets between mangrove dominated ecosystems and peatlands (Appendix I.a). The shorter dataset might show a higher CAR of a coastal wetland due to the partial cycle of the ongoing OM degradation (Breithaupt et al., 2014). Although the dataset from SAL suggests that 100 years dataset is suitable to represent 
the stabilized long-term CAR of the lagoon (Chapter 4.5.2), the length of "suitable dataset representation" can vary between sites. Differentiation between similar ecosystems, in this case between mangrove dominated ecosystems and peatlands, in comparing the CAR of tropical coastal wetlands is therefore necessary.

Due to lack of data in coastal tropical region particularly outside SE Asia, it is as yet not possible to compare the CAR of Indonesian costal peatland with the other tropical coastal peatlands. However, in comparison with the CAR of other inland tropical peatlands, Indonesian coastal peatlands have a high potential in sequester C (Fig. 5.2). This is possibly due to the generally wetter climates in the coastal areas than the inlands (Mongillo and Zierdt-Warshaw, 2000) hence the water table of the coastal peatlands are better maintained and the $\mathrm{OM}$ are better preserved.

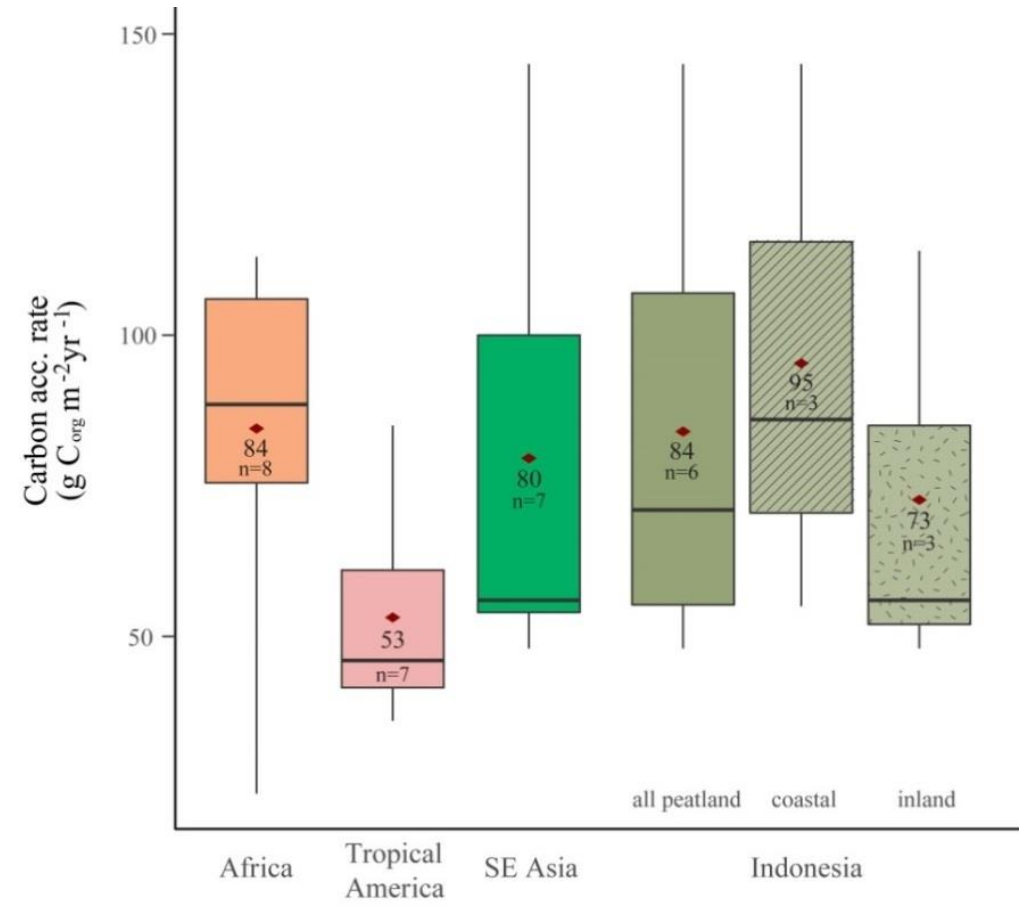

Fig. 5.2. CAR comparison of global tropical peatlands. Red diamond symbols represent the average CAR value of each group. $n$ represent number of sites included. Datasets used are listed in Appendix I.b

\subsection{Resilience of Indonesian coastal wetlands to disturbances}

Indonesian coastal wetlands have shown resilience to natural disturbances in the past.

Under their natural condition, coastal peatlands in Indonesia tend to be resistant to 
drought due to their high humidity that acts as fire barriers (Chapter 2.5.2). Hence, these ecosystems were able to maintain their ecosystem functions to sequester carbon during the drier climatic conditions. Similarly, drier climatic condition did not negatively impact the $\mathrm{C}$ accumulation capacity of mangrove dominated ecosystem in Indonesia (Chapter 4.5.2).

As to the natural disturbances, Indonesian coastal wetland also displayed resilience to anthropogenic disturbances. Indonesian coastal peatland was able to recover its vegetation composition and $\mathrm{C}$ sequestration function from the impacts of logging/timber harvesting, grazing/cut-and-carry, and wild-harvesting activities (Chapter 3.6.). On the other hand, recovery of mangrove dominated ecosystem in Indonesia after human disturbance such as mangrove exploitation, river modification and land use conversion, currently cannot be assessed as the disturbance is still ongoing. Regardless, mangrove dominated ecosystem in Indonesia can still maintain its $\mathrm{C}$ sink capacity despite the severe human disturbances in the ecosystem (Chapter 4.5.2).

\subsection{Implications for conservation, management and restoration of coastal wetlands in Indonesia}

\subsubsection{Priority setting}

Recently, in order to make the best use of limited resources, conservation and restoration efforts recognized the significance of "priority setting" (Noss et al., 2009; Hagen et al., 2016). Priority setting helps the conservation and restoration practitioners to solve the most critical problems, optimize the efforts and allocate the resources by identifying and classifying one matter in terms of species, ecosystems, areas or actions as more important than the other (Hagen et al., 2016). A thorough understanding of 
ecological values and process and the future fate of the ecosystem is required to set priorities in conservation and restoration planning (Noss et al., 2009).

\section{a. Priority sites}

This research shows that both study sites have considerable $\mathrm{C}$ sequestration capacities. Therefore, these two wetlands can be prioritized for conservation or restoration efforts particularly those that are designated for climate change mitigation (e.g. REDD+). Decisions taken to target these two wetlands for conservation and restoration efforts are therefore appropriate and their statuses need to persevere.

\section{b. Priority actions}

In the face of SLR, this research suggests that the C storage capacity of Sungai Buluh might be jeopardized by the effect of river flooding (Chapter 2.6). To preserve its noteworthy role in global $\mathrm{C}$ sequestration in the future, SLR mitigation action such as the construction of higher levee thus can be prioritized in the Sungai Buluh. On the other hand, SRL will likely favor SAL's capacity to accumulate $\mathrm{C}$ by enhancing $\mathrm{C}_{\text {org }}$ deposition through salinity-induced flocculation (Chapter 4.6.). However, as mangrove acts as the main $\mathrm{C}_{\text {org }}$ source in SAL, the lagoon's capacity to accumulate $\mathrm{C}$ would heavily depend on the existence of the surrounding mangrove forest. Mangrove forest in surrounding SAL is currently threatened by illegal logging and conversion (Setyoko and Rosyadi, 2009). Thus, in SAL's case, it is crucial to take immediate action to prevent further mangrove forest degradation. Better yet, to also minimize the barriers and provide adequate space for future landward migration. 


\section{c. Priority taxa}

Often, wetland restoration frameworks target the recovery of biodiversity (Meli et al., 2014). However, due to lack of resources and ecological deterioration severity, targeting full biodiversity recovery can give unrealistic expectation (Hobbs et al., 2011). In that case, prioritizing some alternative reasonable targets such as an enhanced C sequestration capacity is therefore suggested. Enhancing the sequestration capacity of the targeted ecosystem might be conducted by planting the keystone taxa for rapid $\mathrm{C}$ accumulation. In Sungai Buluh's case, for instance, Freycinetia, Myrtaceae, Calophyllum, Stemonuraceae, Ficus and Euphorbiaceae can be prioritized for peatland C management and conservation (Chapter 2.5.2).

\subsubsection{Conservation and sustainable use}

To supports the success of conservation efforts in coastal wetlands, the issues resulted from the tensions and conflicts between the local stakeholders and conservation practitioners need to be solved (Mulyana et al., 2010). This can be done by accommodating the needs of local people through the allocation of conservation area for sustainable use with some pre-set constrains that are settled to ensure the success of the conservation efforts (Mulyana et al., 2010). The limits of the acceptable natural resource utilization can then follow the past type and magnitude "resilience-friendly" human activities as blueprints. Taking example from the case of Sungai Buluh, grazing or cutand-carry and the collection of timber and NTFP thus can be allowed given that their impacts to the ecosystem were reversible (Chapter 3.6). 


\subsubsection{Restoration frameworks}

Restoration efforts can be very costly (Rey Benayas et al., 2009) while the available funding is often limited (Groves et al., 2002). Thus, to optimize the ecological benefit from the often limited resource, restoration efforts need to be effective and efficient (Rey Benayas et al., 2008; Graham et al., 2013). Developing an accurate restoration framework by appropriately selecting the approaches and allocating the resource can enhance the effectiveness and efficiency of restoration efforts (Holl, 2017).

Restoration option spreads from passive, which is cheaper, to active that is more expensive (Noss et al., 2009). Knowing whether the target ecosystem still have the requirements to passively recover can helps to decide whether the application of an expensive restoration technique is really necessary. Moreover, cost-efficient restoration technique will enable the allocation of resources for the aftercare monitoring and maintenance which is often disregarded (Graham et al., 2017).

Active restoration, which is commonly carried out by planting tree seedlings, is very expensive and often provides unsatisfying outcomes (Meli et al 2017). This is due to the selection of planted taxa that more of economic and conservation interest rather than of their regeneration abilities. The taxa with high regenerative power such as Gnetum, Calophyllum, Ficus and Sapotaceae from Sungai Buluh's case is therefore not only more appropriate to be selected for the regeneration of forest cover through tree planting, but also suitable to be used in lower cost techniques (Chapter 3.6.).

\subsubsection{Conservation and restoration policies}

The current peatland restoration frameworks in Indonesia, which mostly aims for full biodiversity recovery, are designated for 60 years following the concession license granted by the local government. Considering the 170 -years recovery time of Sungai 
Buluh, the 60-years restoration frameworks is undoubtedly insufficient to meet their targets. This suggests that the current restoration policy in Indonesia is not supportive enough. Legal regulation is supposed to support and help the restoration efforts, rather be an obstacle, to accomplish their goals (Aronson et al., 2011). The local policy therefore needs to be evaluated or reformulated more flexibly in accordance to the underlying intention of the restoration project.

More attention also needs to be given in regards to the conservation policy in Indonesia. Taking SAL as an example, although the area is conserved and protected under the Decree No. 6/2001 issued by local government, illegal logging and unauthorized conversion still often occur in the surrounding mangrove forests (Setyoko and Rosyadi, 2009). It appears that the implementation of the decree has been weak and ineffective due to (1) lack of resources, (2) poor communication between the government and local people, (3) unawareness from local people of the purpose and content of the decree, (4) unreliable law enforcement, and (5) overlap of authority amongst different government/non-government organizations (Setyoko and Rosyadi, 2009). As the existence of surrounding mangrove is crucial to maintain SAL's capacity to accumulate $\mathrm{C}$, a strengthened implementation of conservation policy is required and the identified problems need to be solved urgently.

\subsection{Future challenges}

Despite of the implications provided by this research to enhance the conservation, management and restoration efforts of the coastal wetlands particularly in Indonesia, there are still some challenges and further works identified that need to be solved and undertaken in the future to help ensuring the sustainability of the values and functions these important ecosystems. 


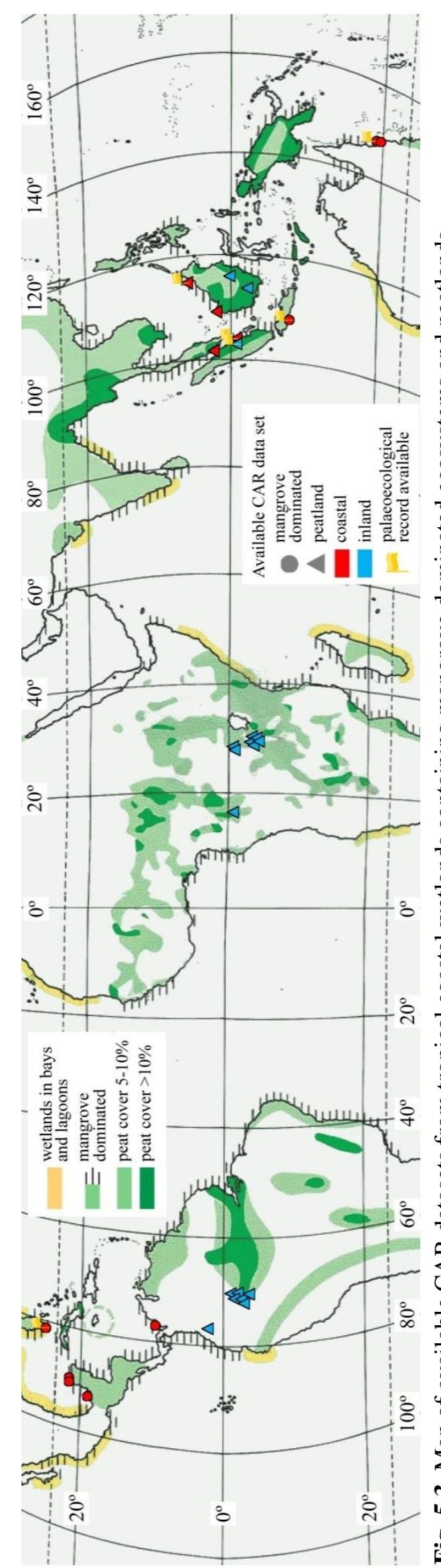

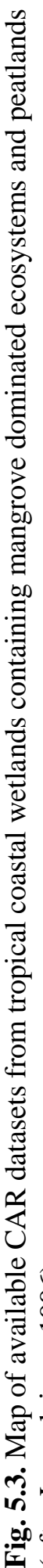

\subsubsection{Similar studies}

Coastal wetlands are currently of main interest in relation to global sea level rise and climate change mitigation for they have high $\mathrm{C}$ sequestration capacity (Grimsditch et al., 2012) with long-term CAR considered to best reflect the future trend (Breithaupt et al., 2014). Yet the available information regarding the long-term belowground $\mathrm{C}$ accumulation of global coastal wetlands remains surprisingly limited with lack representation of the different coastal ecosystems or geographical regions (Fig. 5.3). Particularly for mangrove dominated ecosystems, the available long-term $\mathrm{C}$ accumulation data comprise only around 100 years. More studies focusing on long-term C sequestration in coastal wetlands are therefore required to conduct.

The available palaeoecological information complementing the available long-term $\mathrm{C}$ dataset is also very scarce (Fig. 5.3). Such information is crucial to thoroughly 
understand the dynamics of $\mathrm{C}$ sequestration in coastal wetlands as well as the controlling factors. This is particularly important as the different ecosystems, as well as their $\mathrm{C}$ sequestration capacities, often respond differently to the same environmental factor (Webb et al., 2013; Hapsari et al., 2017). More palaeoecological studies that complement the available long-term $\mathrm{C}$ sequestration data therefore need to be carried out.

\subsubsection{Pollen and vegetation relationship}

The assemblages of pollen and spores in the core generally reflect the vegetation of the surrounding area at the time of their deposition (Bradley, 1999). However, there are still biases in the data due to the differences in pollen production, dispersibility and preservation. Unless the biases are fully addressed, the pollen data cannot be used quantitatively (Williams and Jackson, 2003).

Taking the case of Sungai Buluh peatland as an example, the degrees of acceptable timber harvesting in Sungai Buluh peatland cannot be defined using the available pollen data (Chapter 3.6.). The pollen-vegetation relationship in Sungai Buluh peatland needs to be previously determined in order to "transpose" the $30 \%$ reduction of pollen of forest trees into a coverage area. Unlike in Europe and North-South America where the relationships between pollen rain and vegetation cover are very well explored (e.g. Rull, 2001; Sugita, 2007; Dawson et al., 2016), the pollen-vegetation relationship in Southeast Asia especially Indonesia has never been studied. Thus, studies assessing the pollen-vegetation relationship are needed and encouraged in South East Asian regions, especially Indonesia with its vast coastal wetlands. 


\section{References}

Aronson, J., Brancalion, P.H.S., Durigan, G., Rodrigues, R.R., Engel, V.L., Tabarelli, M., Torezan, J.M.D., Gandolfi, S., de Melo, A.C.G., Kageyama, P.Y., Marques, M.C.M., Nave, A.G., Martins, S.V., Gandara, F.B., Reis, A., Barbosa, L.M., Scarano, F.R., 2011. What Role Should Government Regulation Play in Ecological Restoration? Ongoing Debate in São Paulo State, Brazil. Restoration Ecology 19, 690-695. doi:10.1111/j.1526-100X.2011.00815.x

Bradley, R.S., 1999. Paleoclimatology: Reconstructing Climates of the Quaternary. International Geophysics 68, 1-614. https://doi.org/10.1016/S0074-6142(99)80011-4

Breithaupt, J.L., Smoak, J.M., Smith III, T.J., Sanders, C.J., 2014. Temporal variability of carbon and nutrient burial, sediment accretion, and mass accumulation over the past century in a carbonate platform mangrove forest of the Florida Everglades. Journal of Geophysical Research: Biogeosciences 119, doi:10.1002/2014JG002715.

Dawson, A., Paciorek, C.J., McLachlan, J.S., Goring, S., Williams, W., Jackson, S.T., 2016. Quantifying pollen-vegetation relationships to reconstruct ancient forests using 19th-century forest composition and pollen data. Quaternary Science Reviews 137, 156-175. https://doi.org/10.1016/j.quascirev.2016.01.012

Graham, L.L.B., Giesen, W., Page, S.E., 2017. A common-sense approach to tropical peat swamp forest restoration in Southeast Asia. Restoration Ecology 25(2), 312321. doi:10.1111/rec. 12465

Graham, L.L.B., Turjaman, M., Page, S.E., 2013. Shorea balangeran and Dyera polyphylla (syn. Dyera lowii) as tropical peat swamp forest restoration transplant species: effects of mycorrhizae and level of disturbance. Wetlands Ecology and Management 21, 307-321. doi:10.1007/s11273-013-9302-x

Grimsditch, G., Alder, J., Nakamura, T., Kenchington, R., Tamelander, J., 2013. The blue carbon special edition - Introduction and overview. Ocean and Coastal Management 83, 1-4.

Groves, C.R., Jensen, D.B, Valutis, L.L, Redford, K.H., Shaffer, M.L., Scott, J.M, Baumgartner, J.V, Higgins, J.V., Beck, M.W., Anderson, M.G.,2002. Planning for Biodiversity Conservation: Putting Conservation Science into Practice. BioScience 52(6), 499-512.

Hagen, D., Kotiaho, J., Kareksela, S., Lindhagen, A., Isaksson, D., Päivinen, J., Svavardóttir, K., Tennokene, M., Hansen, K.T., 2016. Restoration priorities and strategies: Restoration to protect biodiversity and enhance Green Infrastructure: Nordic example of priorities and needs for strategic solutions. Nordic Council of Ministers. Copenhagen, Denmark.

Hapsari, KA., Biagioni, S., Jennerjahn, T., Reimer, P.M., Saad, A., Sabiham, S. \& Behling, H. (2017) Environmental dynamics and carbon accumulation rate of a tropical peatland in Central Sumatra, Indonesia. Quaternary Science Reviews 169, 173-187. doi:10.1016/j.quascirev.2017.05.026 
Hobbs, R.J., Hallett, L.M., Ehrlich, P.R., Mooney, H.A., 2011. Intervention Ecology: Applying Ecological Science in the Twenty-first Century. BioScience 61(6), 442450. https://doi.org/10.1525/bio.2011.61.6.6

Holl, K.D., 2017. Restoring tropical forests from the bottom up. Science 355, 455-456. doi:10.1126/science.aam5432

Meli, P., Holl, K.D., Rey Benayas, J.M., Jones, H.P., Jones, P.C., Montoya, D., Mateos, D.M., 2017. A global review of past land use, climate, and active vs. passive restoration effects on forest recovery. PLoS ONE 12(2), e0171368. doi:10.1371/journal.pone.0171368

Meli, P., Rey Benayas, J.M., Balvanera, P., Martínez Ramos, M., 2014. Restoration Enhances Wetland Biodiversity and Ecosystem Service Supply, but Results Are Context-Dependent: A Meta-Analysis. PLoS ONE 9(4), e93507. https://doi.org/10.1371/journal.pone.0093507

Mongillo, J.F., Zierdt-Warshaw, L., 2000. Encyclopedia of Environmental Science. Oryx Press. Phoenix, Arizona-United States.

Mulyana, A., Moeliono, M., Minnigh, P., Indriatmoko, Y., Limberg, G., Utomo, N.A., ... Hamzah, 2010. Establishing special use zones in national parks: can it break the conservation deadlock in Indonesia? Brief 1. Bogor, Indonesia: Center for International Forestry Research (CIFOR).

Noss, R., Nielsen, S., Vance-Boland, K., 2009. Prioritizing ecosystems, species and sites for restoration. In: Moilanen, A., Wilson, K.A., Possingham, H.P. (Eds.) Spatial Conservation Prioritisation: Quantitative Methods and Computational Tools Oxford University Press. Oxford, United Kingdom.

Rey Benayas, J.M., Bullock, J.M., Newton, A.C., 2008. Creating woodland islets to reconcile ecological restoration, conservation, and agricultural land use. Frontiers in Ecology and the Environment 6(6), 329-336, doi:10.1890/070057

Rey Benayas, J.M., Newton, A.C., Diaz, A., Bullock, J.M., 2009. Enhancement of Biodiversity and Ecosystem Services by Ecological Restoration: A Meta-Analysis. Science 325, 1121-1124. doi:10.1126/science. 1172460

Rull, V., 2001. A quantitative palynological record from the early Mioecene of Western Venezuela, with emphasis on mangroves. Palynology 25(1), 109-126. https://doi.org/10.2113/0250109

Sanders, C.J., Eyre1, B.D., Santos, I.R., Machado, W., Luiz-Silva, W., Smoak, J.M., Breithaupt, J.L., Ketterer, M.E., Sanders, L., Marotta, H., Silva-Filho, E., 2014. Elevated rates of organic carbon, nitrogen, and phosphorus accumulation in a highly impacted mangrove wetland. Geophysical Research Letter, 41, 2475-2480. doi:10.1002/2014GL059789.

Setyoko, P.I., Rosyadi, S., 2009. Problem implementasi kebijakan konservasi sumberdaya: kasus kawasan Segara Anakan Cilacap sebagai zone konservasi terbatas. Jurnal Ilmu Administrasi Negara 9(2), 93 - 102

Sugita, S., 2007. Theory of quantitative reconstruction of vegetation I: pollen from large sites REVEALS regional vegetation composition. The Holocene 17(2), 229-241. 
https://doi.org/10.1177/0959683607075837

Webb, E.L., Friess, D.A., Krauss, K.W., Cahoon, D.R., Guntenspergen, G.R., Phelps, J., 2003. A global standard for monitoring coastal wetland vulnerability to accelerated sea-level rise. Nature Climate Change 3, 458-465. doi:10.1038/nclimate1756

Williams, J.W., Jackson, S.T., 2003. Palynological and AVHRR observations of modern vegetational gradients in eastern North America. The Holocene 13(4), 485497.

Wüst, R.A.J., Bustin, R.M., Lavkulich, L.M., 2003. New classification systems for tropical organic-rich deposits based on studies of the Tasek Bera Basin, Malaysia. Catena 53, 133-163. doi:10.1016/S0341-8162(03)00022-5

Yulianto, E., Hirakawa, K., 2006. Vegetation and environmental change in the early Middle holocene at a tropical peat swamp forest, Central Kalimantan, Indonesia. Tropics 15, 65-73. 


\section{Appendix I}

\section{Available dataset on $\mathrm{C}$ accumulation rates of tropical coastal wetlands and tropical peatlands}


Appendix I

Available dataset on CAR of tropical coastal wetlands and peatlands

Appendix I.a. Available dataset on $\mathrm{C}$ accumulation rate of tropical coastal wetlands

\begin{tabular}{|c|c|c|c|c|c|c|c|}
\hline No. & \multicolumn{4}{|r|}{ Sites } & $\begin{array}{l}\text { Record length } \\
\text { (years) }\end{array}$ & $\begin{array}{c}\mathrm{C} \text { accumulation } \\
\text { rate } \\
\left(\mathrm{g} \mathrm{C} \mathrm{m}^{-2} \mathrm{yr}^{-1}\right)\end{array}$ & Reference \\
\hline 1 & \multirow{6}{*}{ 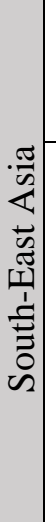 } & 矛 & \multirow{4}{*}{ 芑 } & $\begin{array}{l}\text { Mendaram, } \\
\text { Borneo }\end{array}$ & 2776 & 53 & Dommain et al., 2015 \\
\hline 2 & & \multirow{5}{*}{$\begin{array}{l}\frac{\pi}{\sqrt{0}} \\
\stackrel{0}{\tilde{0}} \\
\frac{0}{\Xi}\end{array}$} & & $\begin{array}{l}\text { Teluk Keramat, } \\
\text { Borneo }\end{array}$ & 4521 & 86 & \multirow{2}{*}{$\begin{array}{c}\text { Neuzil, 1997; } \\
\text { Dommain et al., } 2011\end{array}$} \\
\hline 3 & & & & \begin{tabular}{|l} 
Siak Kanan, \\
Sumatra
\end{tabular} & 5986 & 145 & \\
\hline 4 & & & & $\begin{array}{l}\text { Sungai Buluh, } \\
\text { Sumatra } \\
\end{array}$ & 13419 & 55 & Hapsari et al., 2017 \\
\hline \multirow{2}{*}{5} & & & \multirow{6}{*}{ 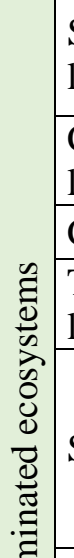 } & \multirow{2}{*}{$\begin{array}{l}\text { Segara Anakan } \\
\text { lagoon, Java }\end{array}$} & 400 & 126 & \multirow{2}{*}{ This study (Chapter 4) } \\
\hline & & & & & 100 & 153 & \\
\hline 6 & \multirow{3}{*}{\multicolumn{2}{|c|}{ : }} & & $\begin{array}{l}\text { Celestun } \\
\text { lagoon }\end{array}$ & 100 & 69 & \multirow{3}{*}{ Gonneea et al., 2004} \\
\hline 7 & & & & Chelem lagoon & 100 & 86 & \\
\hline 8 & & & & \begin{tabular}{|l|} 
Terminos \\
lagoon
\end{tabular} & 100 & 59 & \\
\hline 9 & \multirow[t]{2}{*}{ 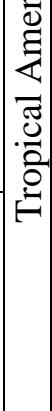 } & $\begin{array}{l}\frac{\pi}{0} \\
\frac{0}{\tilde{0}} \\
\frac{0}{0} \\
\end{array}$ & & Soledad lagoon & 100 & 367 & $\begin{array}{l}\text { Ruiz-Fernández et al., } \\
2011\end{array}$ \\
\hline 10 & & 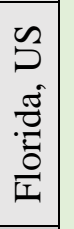 & \multirow[t]{3}{*}{ 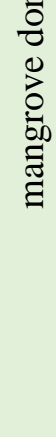 } & $\begin{array}{l}\text { Everglades } \\
\text { National Park }\end{array}$ & 100 & 147 & Smoak et al., 2013 \\
\hline 11 & \multirow{2}{*}{\multicolumn{2}{|c|}{ 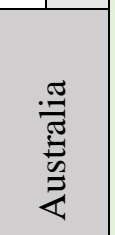 }} & & $\begin{array}{l}\text { Missionary } \\
\text { Bay }\end{array}$ & 100 & 197 & \multirow[b]{2}{*}{ Brunksill et al., 2002} \\
\hline 12 & & & & $\begin{array}{l}\text { Hinchinbrook } \\
\text { Channel }\end{array}$ & 100 & 57 & \\
\hline
\end{tabular}


Appendix I

Available dataset on CAR of tropical coastal wetlands and peatlands

Appendix I.b. Available dataset on $\mathrm{C}$ accumulation rate of tropical peatlands

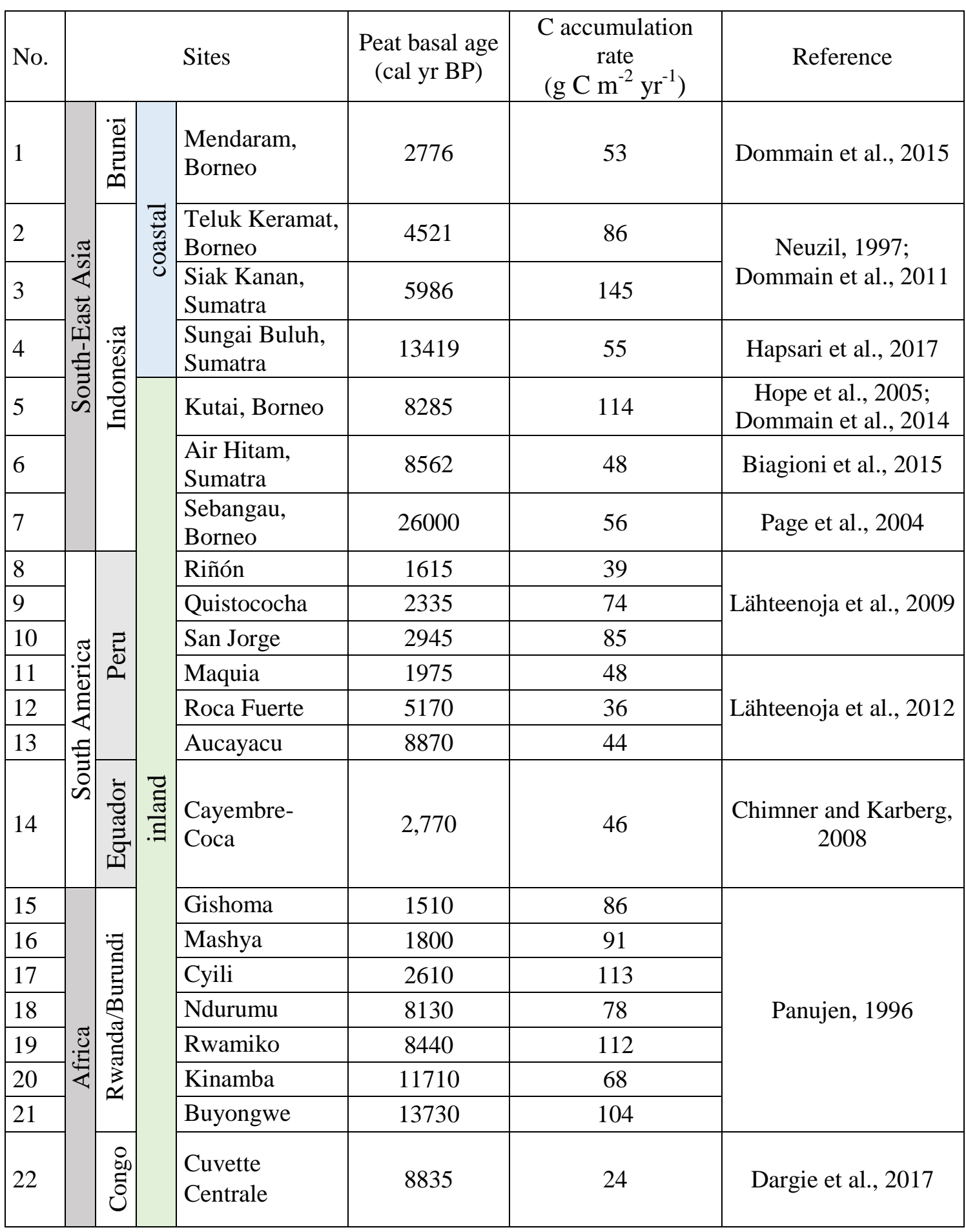




\section{Appendix II}

Complete pollen diagram of Sungai Buluh peatland 
Appendix II

Complete pollen diagram of SB peatland

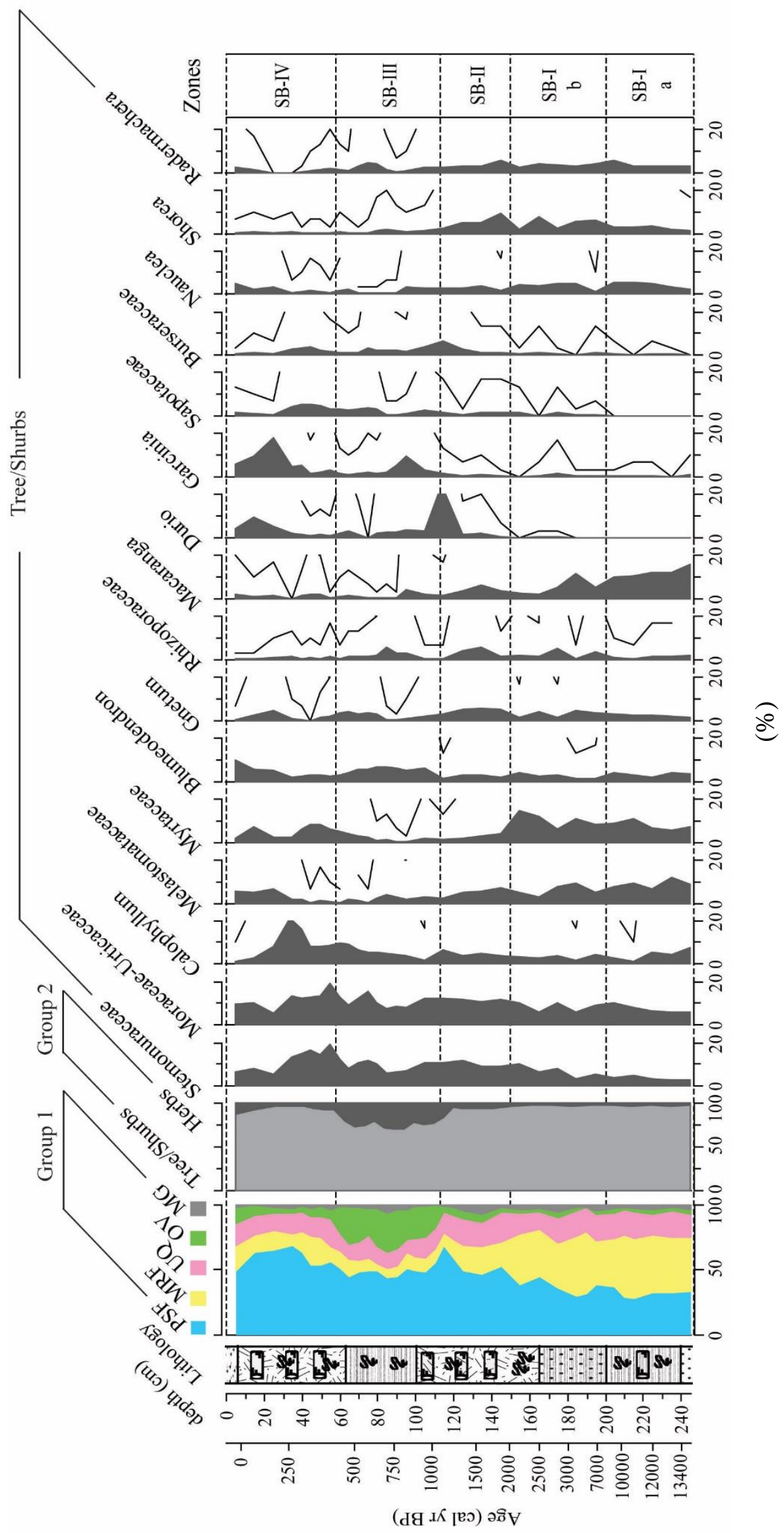




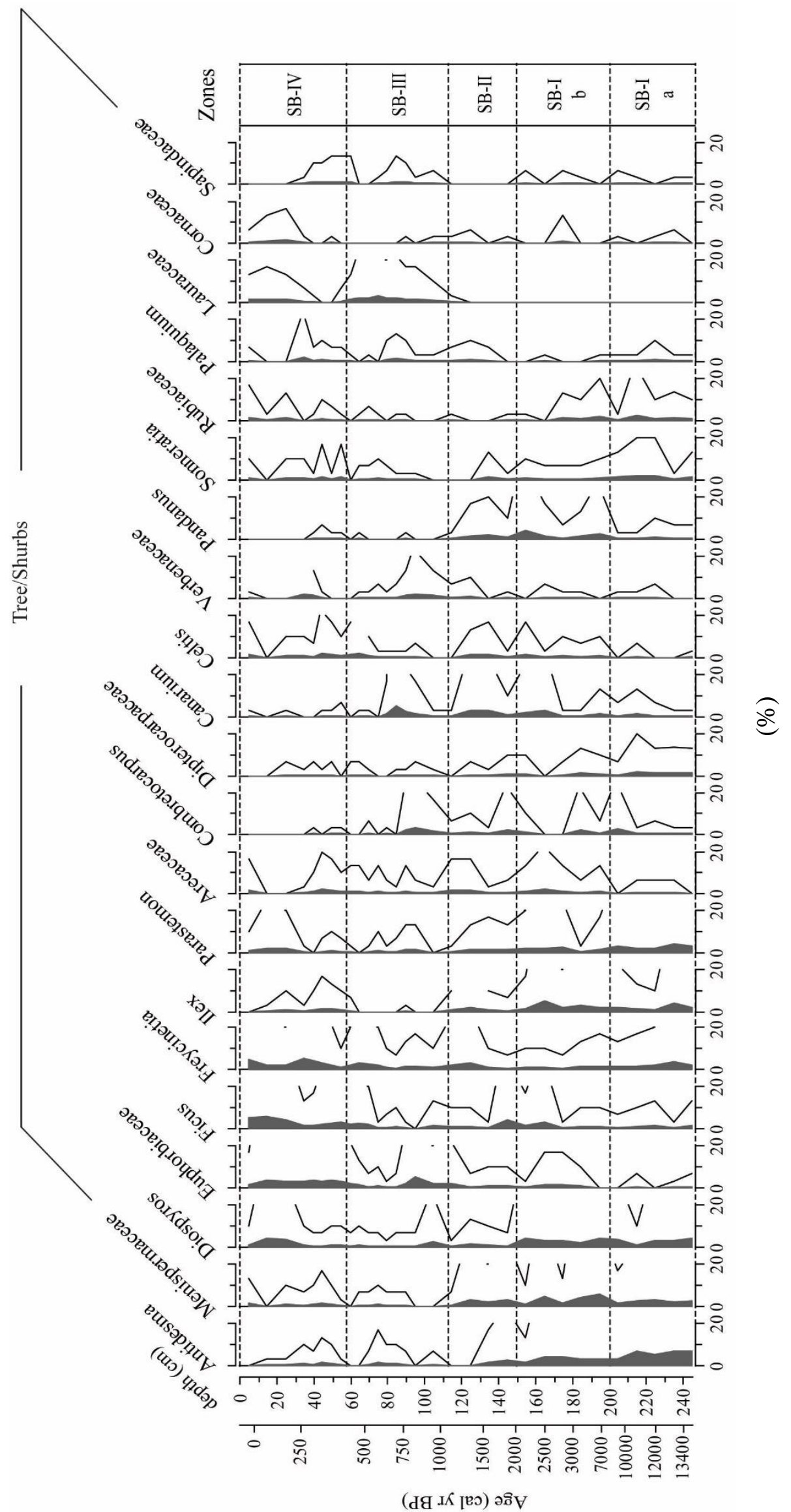




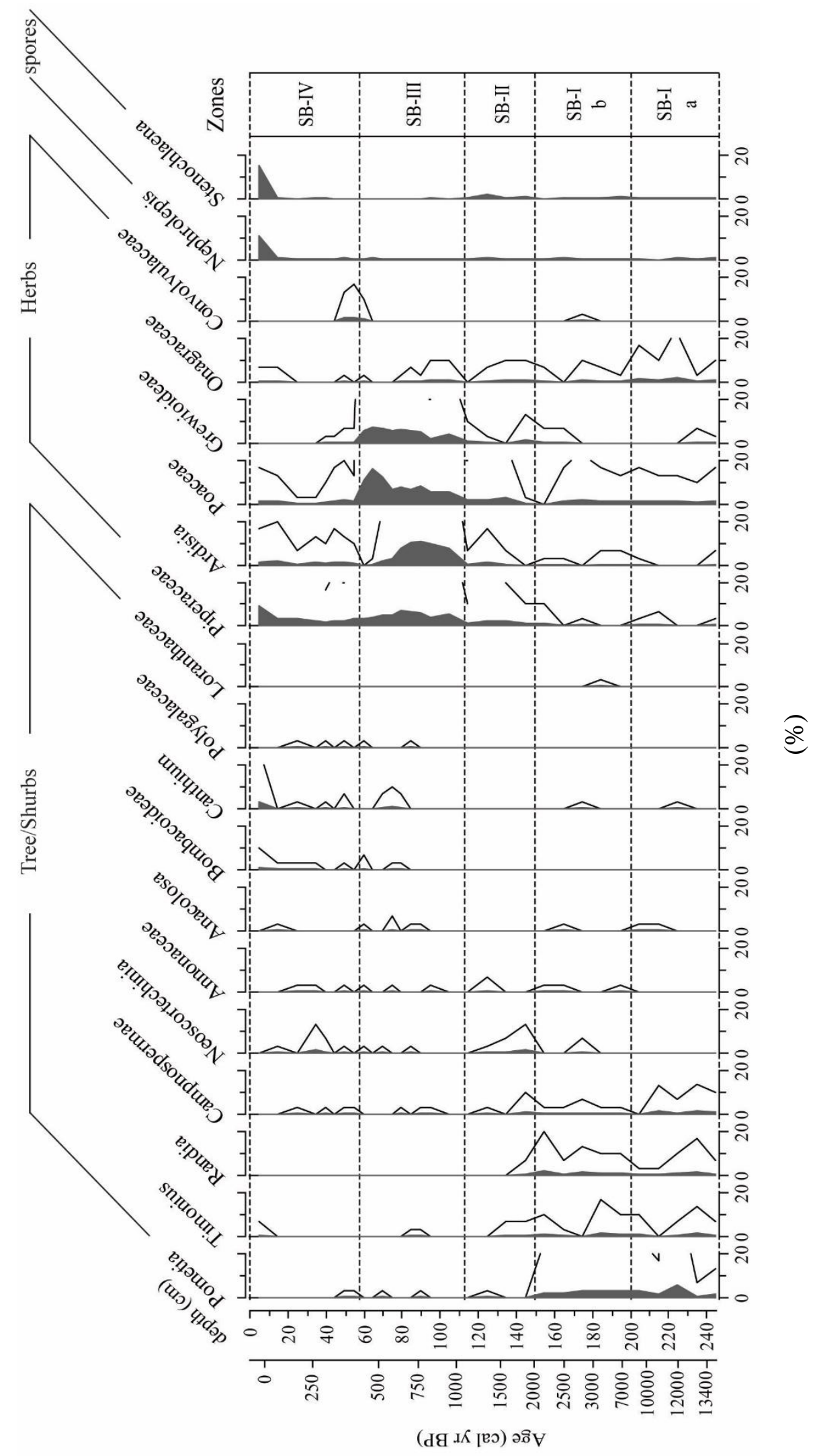




\section{Appendix III}

Complete pollen diagram of Segara Anakan lagoon 


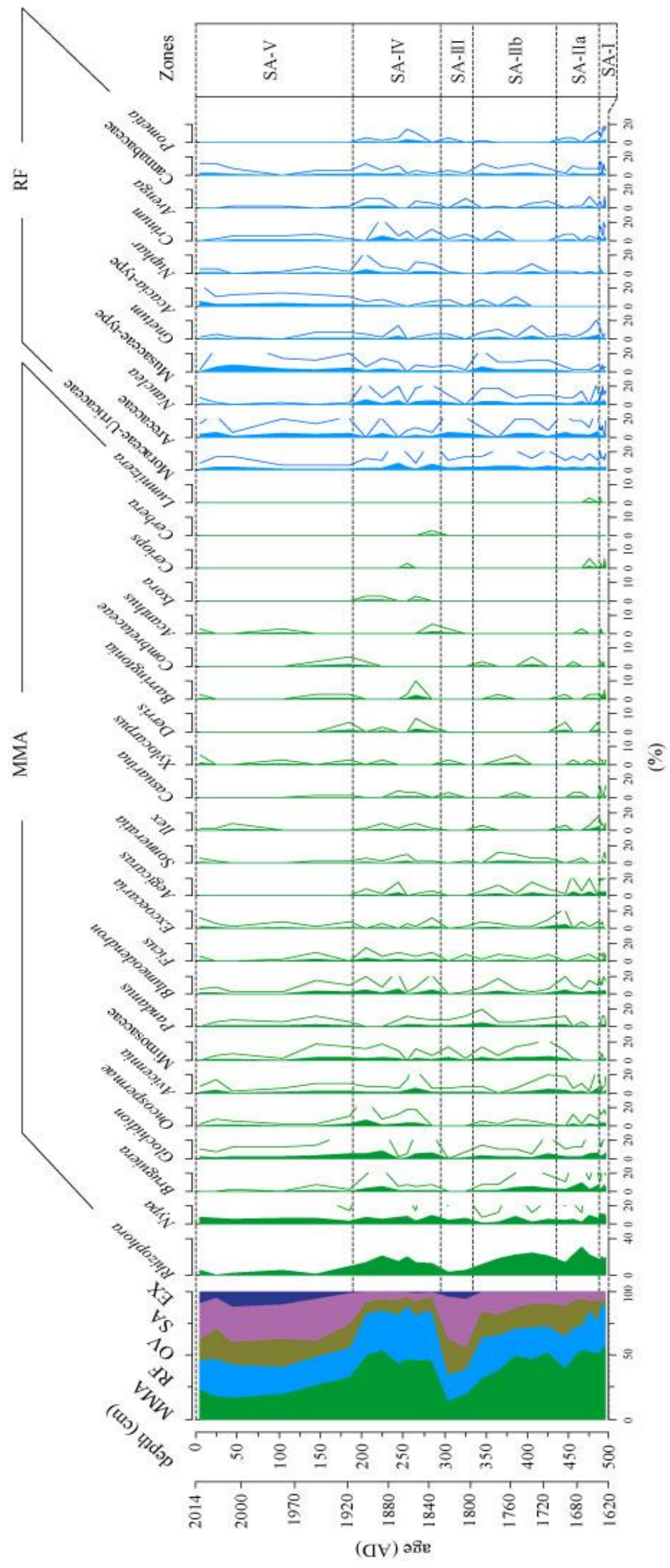




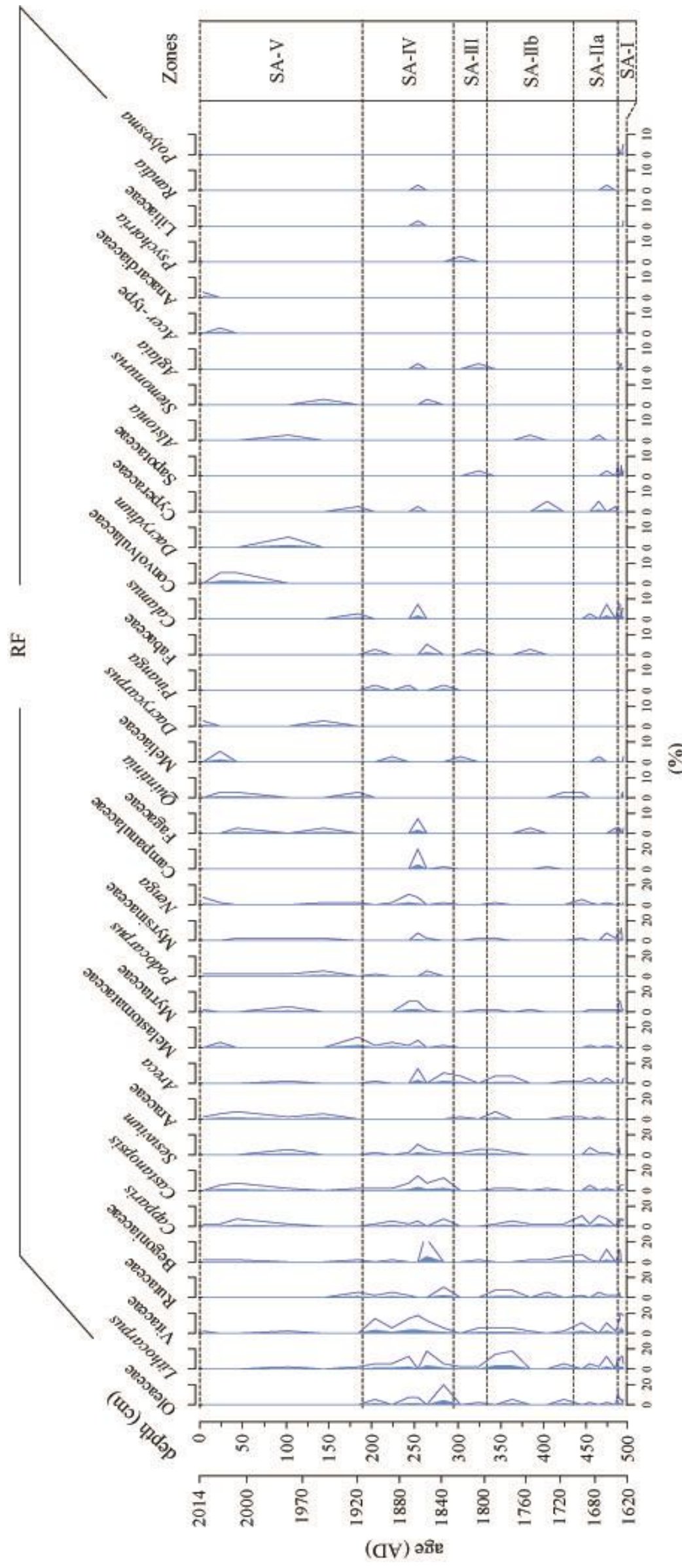




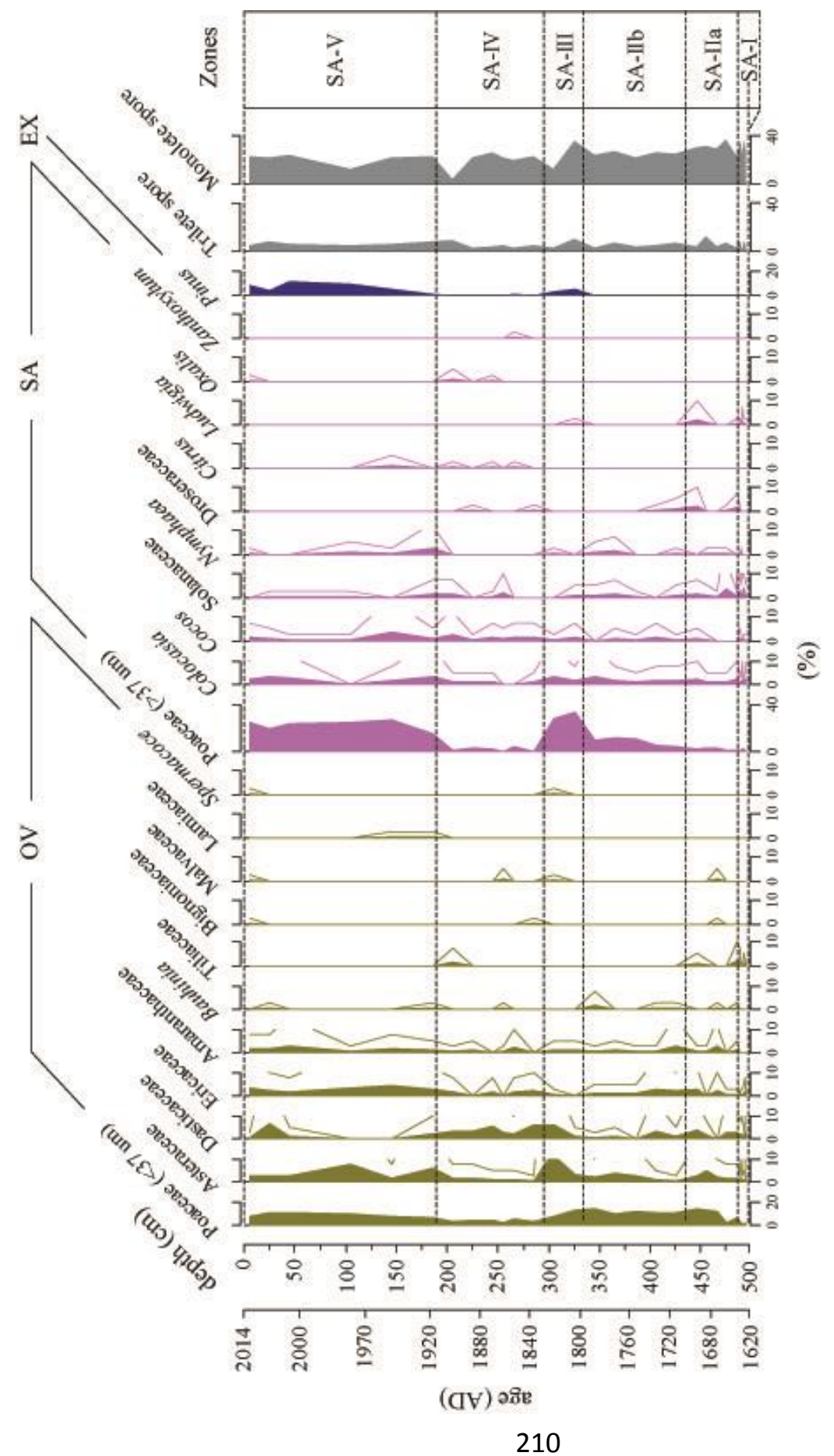




\section{Appendix IV}

List of identified pollen taxa 


\section{Pollen}

\begin{tabular}{|c|c|c|c|}
\hline Picture no. & Plant family & Pollen taxon & $\begin{array}{l}\text { Reference } \\
\text { site }\end{array}$ \\
\hline \multirow[t]{2}{*}{$\begin{array}{l}1 \\
2 \\
\end{array}$} & Acanthaceae & $\begin{array}{l}\text { Acanthus } \\
\text { Avicennia }\end{array}$ & $\begin{array}{l}\text { b) } \\
\text { b) }\end{array}$ \\
\hline & Aizoaceae & Sesuvium & b) \\
\hline \multirow[t]{6}{*}{3} & Amaranthaceae & & b) \\
\hline & Amaryllidoideae & Crinum & b) \\
\hline & Anacardiaceae & $\begin{array}{l}\text { Anacardiaceae type } \\
\text { Campnosperma }\end{array}$ & $\begin{array}{l}\text { b) } \\
\text { a) }\end{array}$ \\
\hline & Anisophylleaceae & Combretocarpus & a) \\
\hline & Annonaceae & & a) \\
\hline & Apocynaceae & $\begin{array}{l}\text { Alstonia } \\
\text { Cerbera }\end{array}$ & $\begin{array}{l}\text { b) } \\
\text { b) }\end{array}$ \\
\hline \multirow[t]{2}{*}{4} & Aquifoliaceae & Ilex & a) b) \\
\hline & Araceae & $\begin{array}{l}\text { Araceae type } \\
\text { Colocasia }\end{array}$ & $\begin{array}{l}\text { b) } \\
\text { b) }\end{array}$ \\
\hline $\begin{array}{l}6 \\
7 \\
8 \\
9\end{array}$ & Arecaceae & $\begin{array}{l}\text { Areca } \\
\text { Arecaceae type } \\
\text { Calamus } \\
\text { Cocos } \\
\text { Nenga } \\
\text { Nypa } \\
\text { Oncosperma } \\
\text { Pinanga } \\
\end{array}$ & $\begin{array}{l}\text { b) } \\
\text { a) b) } \\
\text { b) } \\
\text { b) } \\
\text { b) } \\
\text { b) } \\
\text { b) } \\
\text { b) } \\
\end{array}$ \\
\hline \multirow[t]{2}{*}{10} & Asteraceae & & b) \\
\hline & Begoniaceae & & b) \\
\hline 11 & Bignoniaceae & $\begin{array}{l}\text { Bignoniaceae type } \\
\text { Radermachera }\end{array}$ & $\begin{array}{l}\text { b) } \\
\text { a) }\end{array}$ \\
\hline \multirow[t]{2}{*}{12} & Burseraceae & $\begin{array}{l}\text { Canarium } \\
\text { Burseraeae type }\end{array}$ & a) \\
\hline & Campanulaceae & & b) \\
\hline 13 & Cannabaceae & $\begin{array}{l}\text { Cannabaceae type } \\
\text { Celtis }\end{array}$ & $\begin{array}{l}\text { b) } \\
\text { a) }\end{array}$ \\
\hline 14 & Capparaceae & Capparis & b) \\
\hline \multirow[t]{2}{*}{15} & Casuarinaceae & Casuarina & b) \\
\hline & Chrysobalanaceae & Parastemon & a) \\
\hline $\begin{array}{l}16 \\
17\end{array}$ & Clusiaceae & $\begin{array}{l}\text { Calophyllum } \\
\text { Garcinia }\end{array}$ & $\begin{array}{l}\text { a) } \\
\text { a) }\end{array}$ \\
\hline $\begin{array}{l}18 \\
19\end{array}$ & Combretaceae & $\begin{array}{l}\text { Combretaceae } \\
\text { Lumnitzera }\end{array}$ & $\begin{array}{c}\text { Ist here not } \\
\text { in a? } \\
\text { b) }\end{array}$ \\
\hline
\end{tabular}


List of identified pollen taxa

\begin{tabular}{|c|c|c|c|}
\hline \multirow[t]{3}{*}{20} & Cornaceae & & a) b) \\
\hline & Convolvulaceae & & a) b) \\
\hline & Cyperaceae & & b) \\
\hline 21 & Dasticaceae & & b) \\
\hline 22 & Dipterocarpaceae & $\begin{array}{l}\text { Dipterocarpaceae type } \\
\text { Shorea }\end{array}$ & $\begin{array}{l}\text { a) } \\
\text { a) }\end{array}$ \\
\hline \multirow[t]{2}{*}{23} & Droseraceae & & b) \\
\hline & Ebenaceae & Diospyros & a) \\
\hline 24 & Ericaceae & & b) \\
\hline 25 & Escalloniaceae & Polyosma & b) \\
\hline \multirow[t]{2}{*}{$\begin{array}{l}27 \\
28\end{array}$} & Euphorbiaceae & $\begin{array}{l}\text { Blumeodendron } \\
\text { Euphorbiaceae type } \\
\text { Excoecaria } \\
\text { Macaranga } \\
\text { Neoscortechinia }\end{array}$ & $\begin{array}{l}\text { a) b) } \\
\text { a) } \\
\text { b) } \\
\text { a) } \\
\text { a) }\end{array}$ \\
\hline & Fabaceae & & b) \\
\hline $\begin{array}{l}29 \\
30 \\
\end{array}$ & Fagaceae & $\begin{array}{l}\text { Castanopsis } \\
\text { Fagaceae-type } \\
\text { Lithocarpus }\end{array}$ & $\begin{array}{l}\text { b) } \\
\text { b) } \\
\text { b) }\end{array}$ \\
\hline \multirow[t]{2}{*}{31} & Gnetaceae & Gnetum & a) b) \\
\hline & Lamiaceae & & b) \\
\hline 32 & Lecythidaceae & Barringtonia & b) \\
\hline $\begin{array}{l}33 \\
34 \\
\end{array}$ & Leguminosae & $\begin{array}{l}\text { Acacia-type } \\
\text { Bauhinia } \\
\text { Derris }\end{array}$ & $\begin{array}{l}\text { b) } \\
\text { b) } \\
\text { b) }\end{array}$ \\
\hline & Liliaceae & & b) \\
\hline 35 & Loranthaceae & & a) \\
\hline $\begin{array}{l}36 \\
37 \\
38 \\
\end{array}$ & Lythraceae & $\begin{array}{l}\text { Sonneratia type } \\
\text { Sonneratia } \text { cf. alba } \\
\text { Sonneratia } \text { cf. apetala } \\
\text { Sonneratia } \text { cf. caseolaris } \\
\text { Sonneratia } \text { cf. ovata }\end{array}$ & $\begin{array}{l}\text { a) b) } \\
\text { b) } \\
\text { b) } \\
\text { b) } \\
\text { b) }\end{array}$ \\
\hline $\begin{array}{l}39 \\
40\end{array}$ & Malvaceae & $\begin{array}{l}\text { Bombacoideae } \\
\text { Durio } \\
\text { Grewioideae } \\
\text { Malvaceae type }\end{array}$ & $\begin{array}{l}\text { a) } \\
\text { a) } \\
\text { a) } \\
\text { b) }\end{array}$ \\
\hline 41 & Meliaceae & $\begin{array}{l}\text { Aglaia } \\
\text { Meliaceae type } \\
\text { Xylocarpus }\end{array}$ & $\begin{array}{l}\text { b) } \\
\text { b) } \\
\text { b) }\end{array}$ \\
\hline & Melastomataceae & & a) b) \\
\hline & Menispermaceae & & a) \\
\hline
\end{tabular}


List of identified pollen taxa

\begin{tabular}{|c|c|c|c|}
\hline & Mimosaceae & & b) \\
\hline \multirow[t]{3}{*}{$\begin{array}{l}42 \\
43\end{array}$} & Moraceae-Urticaceae & $\begin{array}{l}\text { Moraceae-Urticaceae type } \\
\text { Ficus }\end{array}$ & $\begin{array}{l}\text { a) b) } \\
\text { a) b) }\end{array}$ \\
\hline & Musaceae & & b) \\
\hline & Myrsinaceae & & b) \\
\hline 44 & Myrtaceae & & a) b) \\
\hline \multirow[t]{3}{*}{45} & Nymphaeaceae & $\begin{array}{l}\text { Nuphar } \\
\text { Nymphaea }\end{array}$ & $\begin{array}{l}\text { b) } \\
\text { b) }\end{array}$ \\
\hline & Olacaceae & Anacolosa & a) \\
\hline & Oleaceae & & b) \\
\hline \multirow[t]{2}{*}{46} & Onagraceae & $\begin{array}{l}\text { Onagraceae type } \\
\text { Ludwigia }\end{array}$ & $\begin{array}{l}\text { a) } \\
\text { b) }\end{array}$ \\
\hline & Oxalidaceae & Oxalis & b) \\
\hline \multirow[t]{2}{*}{47} & Pandanaceae & $\begin{array}{l}\text { Freycinetia } \\
\text { Pandanus }\end{array}$ & $\begin{array}{l}\text { a) } \\
\text { a) b) }\end{array}$ \\
\hline & Paracryphiaceae & Quintinia & b) \\
\hline 48 & Phyllanthacaeae & $\begin{array}{l}\text { Antidesma } \\
\text { Glochidion }\end{array}$ & $\begin{array}{l}\text { a) } \\
\text { b) }\end{array}$ \\
\hline 49 & Pinaceae & Pinus & b) \\
\hline 50 & Piperaceae & Piper & a) \\
\hline $\begin{array}{l}51 \\
52\end{array}$ & Poaceae & $\begin{array}{l}\text { wild grass }(<27 \mu \mathrm{m}) \\
\text { cultivated Poaceae }(>27 \mu \mathrm{m} \text {; } \\
\text { e.g. Oryza, Zea })\end{array}$ & $\begin{array}{l}\text { a) b) } \\
\text { b) }\end{array}$ \\
\hline \multirow[t]{2}{*}{$\begin{array}{l}53 \\
54 \\
\end{array}$} & Podocarpaceae & $\begin{array}{l}\text { Dacrycarpus } \\
\text { Dacrydium } \\
\text { Podocarpus } \\
\end{array}$ & $\begin{array}{l}\text { b) } \\
\text { b) } \\
\text { b) }\end{array}$ \\
\hline & Polygalaceae & & a) \\
\hline $\begin{array}{l}55 \\
56 \\
\end{array}$ & Primulaceae & $\begin{array}{l}\text { Aegiceras } \\
\text { Ardisia }\end{array}$ & $\begin{array}{l}\text { b) } \\
\text { a) }\end{array}$ \\
\hline $\begin{array}{l}57 \\
58 \\
59 \\
\end{array}$ & Rhizophoraceae & $\begin{array}{l}\text { Rhizophoraceae type } \\
\text { Bruguiera } \\
\text { Ceriops } \\
\text { Rhizophora } \\
\end{array}$ & $\begin{array}{l}\text { a) b) } \\
\text { b) } \\
\text { b) } \\
\text { b) }\end{array}$ \\
\hline $\begin{array}{l}60 \\
61 \\
62\end{array}$ & Rubiaceae & $\begin{array}{l}\text { Canthium } \\
\text { Ixora } \\
\text { Nauclea } \\
\text { Psychotria } \\
\text { Randia } \\
\text { Rubiaceae type } \\
\text { Spermacoce } \\
\text { Timonius } \\
\end{array}$ & $\begin{array}{l}\text { a) } \\
\text { b) } \\
\text { a) b) } \\
\text { b) } \\
\text { a) b) } \\
\text { a) } \\
\text { b) } \\
\text { a) }\end{array}$ \\
\hline 64 & Rutaceae & $\begin{array}{l}\text { Rutaceae type } \\
\text { Citrus } \\
\text { cf. Zanthoxylum } \\
\end{array}$ & $\begin{array}{l}\text { b) } \\
\text { b) } \\
\text { b) }\end{array}$ \\
\hline
\end{tabular}




\begin{tabular}{|c|l|l|c|}
\hline 65 & Sapindaceae & $\begin{array}{l}\text { Acer-type } \\
\text { Pometia } \\
\text { Sapindaceae type }\end{array}$ & $\begin{array}{c}\text { b) } \\
\text { a) b) } \\
\text { a) }\end{array}$ \\
\hline 66 & Sapotaceae & $\begin{array}{l}\text { Palaquium } \\
\text { Sapotaceae type }\end{array}$ & $\begin{array}{c}\text { a) } \\
\text { a) b) }\end{array}$ \\
\hline 67 & Solanaceae & & b) \\
\hline 68 & Tiliaceae & $\begin{array}{l}\text { Stemonuraceae type } \\
\text { Stemonurus }\end{array}$ & $\begin{array}{c}\text { a) } \\
\text { a) b) }\end{array}$ \\
\hline & Verbenaceae & & b) \\
\hline & Vitaceae & & a) \\
\hline
\end{tabular}

\section{Spores}

\begin{tabular}{|c|l|l|c|}
\hline Picture no. & \multicolumn{1}{|c|}{ Plant family } & \multicolumn{1}{|c|}{ Pollen taxon } & $\begin{array}{c}\text { Reference } \\
\text { site }\end{array}$ \\
\hline 69 & Blechnaceae & Stenochlaena & a) \\
\hline 70 & Davalliaceae & Davallia & a) b) \\
\hline 71 & Monolete spore & & a) b) \\
\hline & Nephrolepidaceae & Nephrolepis & a) \\
\hline 72 & Trilete spore & & a) b) \\
\hline
\end{tabular}

Reference site : a) Sungai Buluh peatland, Sumatra

b) Segara Anakan lagoon, Java 


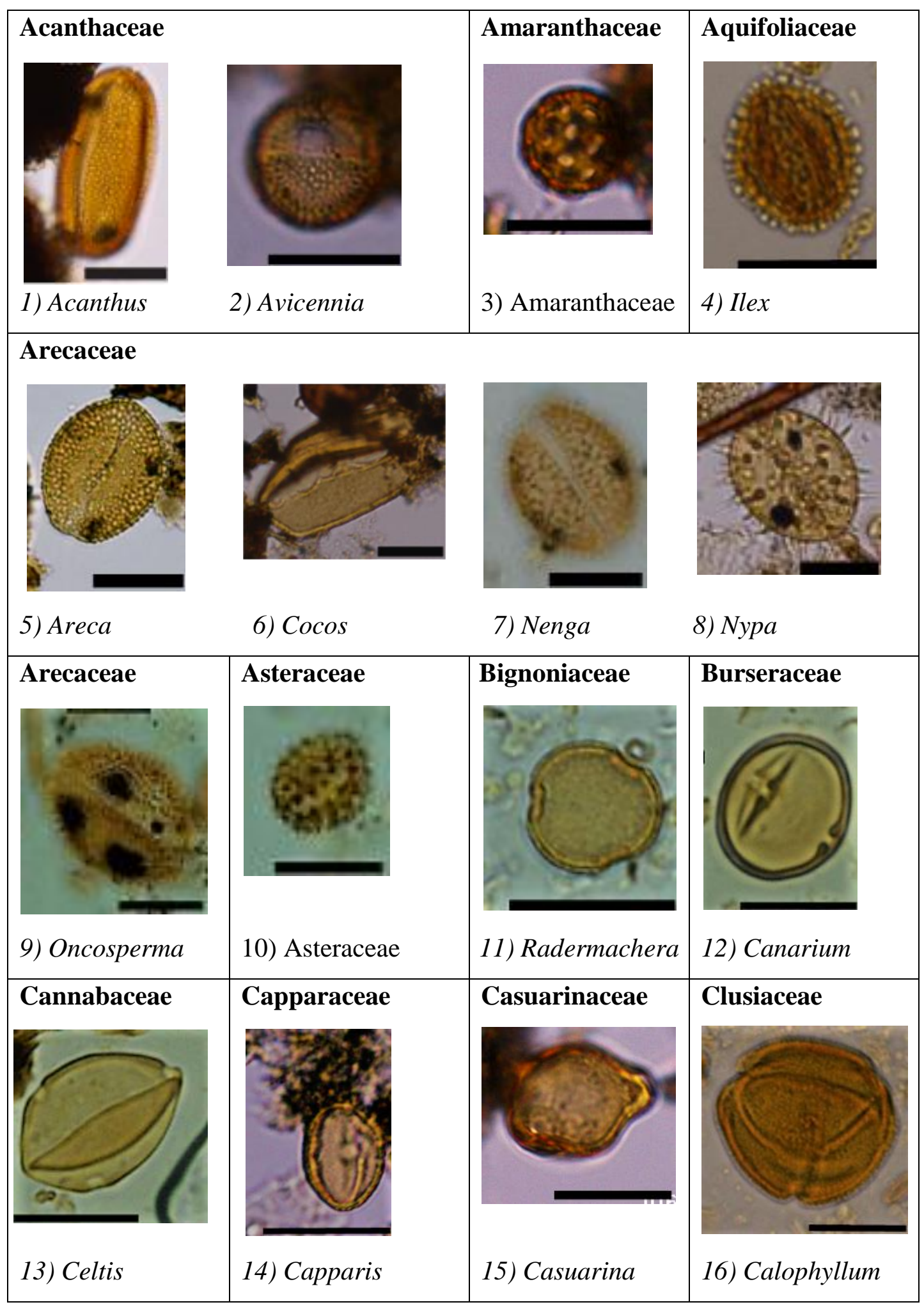




\begin{tabular}{|c|c|c|c|}
\hline Clusiaceae & Combretaceae & & Cornaceae \\
\hline 17) Garcinia & 18) Combretaceae & 19) Lumnitzera & 20) Cornaceae \\
\hline Dasticaceae & Dipterocarpaceae & Droceraceae & Ericaceae \\
\hline 21) Dasticaceae & 22) Shorea & 23) Droceraceae & 24) Ericaceae \\
\hline Escalloniaceae & Euphorbiaceae & & \\
\hline 26) Polyosma & 26) Blumeodendron & 27) Excoecaria & 28) Macaranga \\
\hline Fagaceae & & Gnetaceae & Lecythidaceae \\
\hline 29) Castanopsis & 30) Lithocarpus & 31) Gnetum & 32) Barringtonia \\
\hline
\end{tabular}




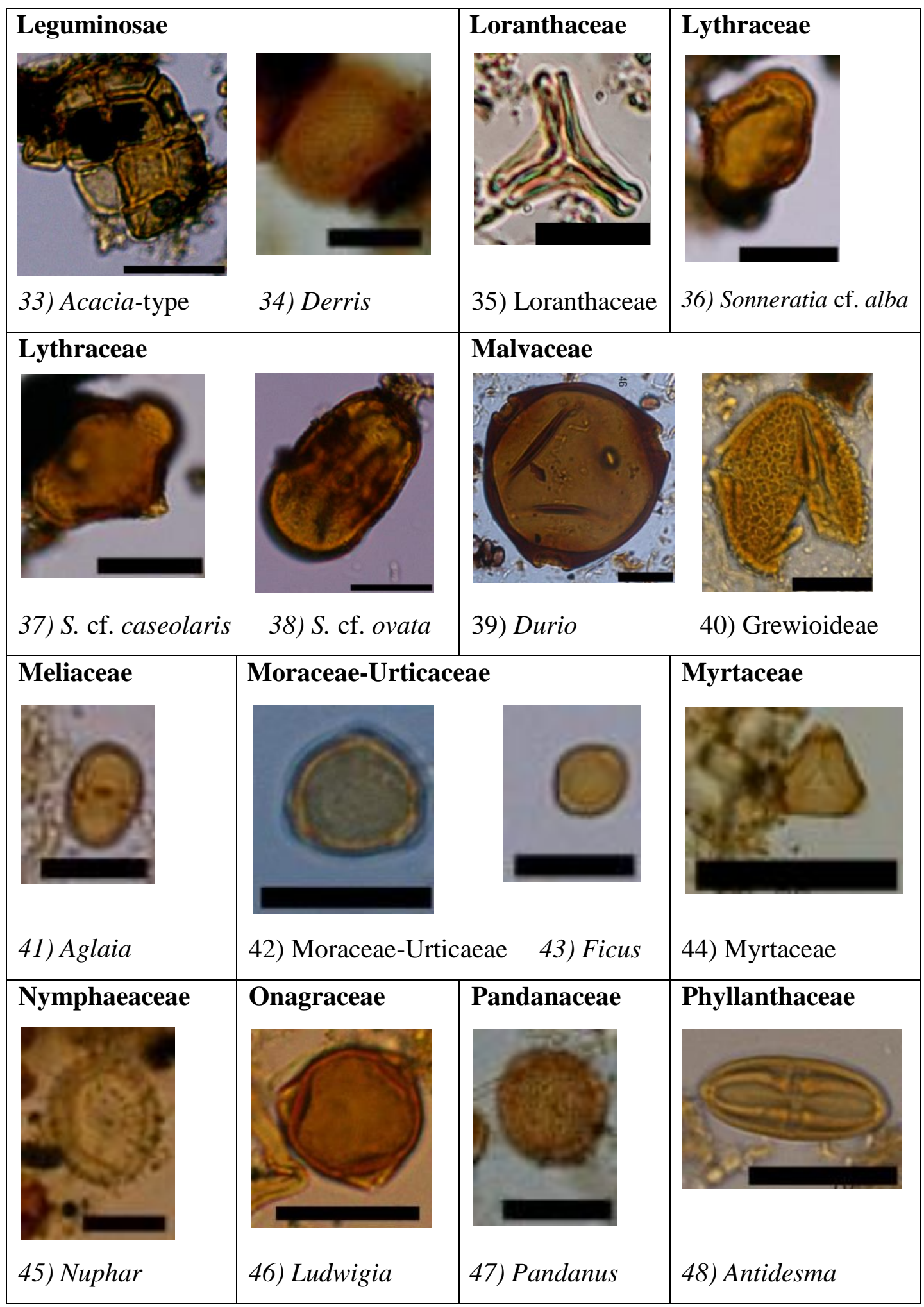




\begin{tabular}{|c|c|c|c|}
\hline Pinaceae & Piperaceae & Poaceae & \\
\hline 49) Pinus & 50) Piper & 51) wild grass & 52) cultivated Poaceae \\
\hline Podocarpaceae & & Primulaceae & \\
\hline 53) Dacrycarpus & 54) Podocarpus & 55) Aegiceras & 56) Ardisia \\
\hline Rhizophoraceae & & & Rubiaceae \\
\hline 57) Bruguiera & 58) Ceriops & 59) Rhizophora & 60) Ixora \\
\hline Rubiaceae & & & Rutaceae \\
\hline 61) Nauclea & 62) Randia & 63) Timonius & 64) Citrus \\
\hline
\end{tabular}


List of identified pollen taxa

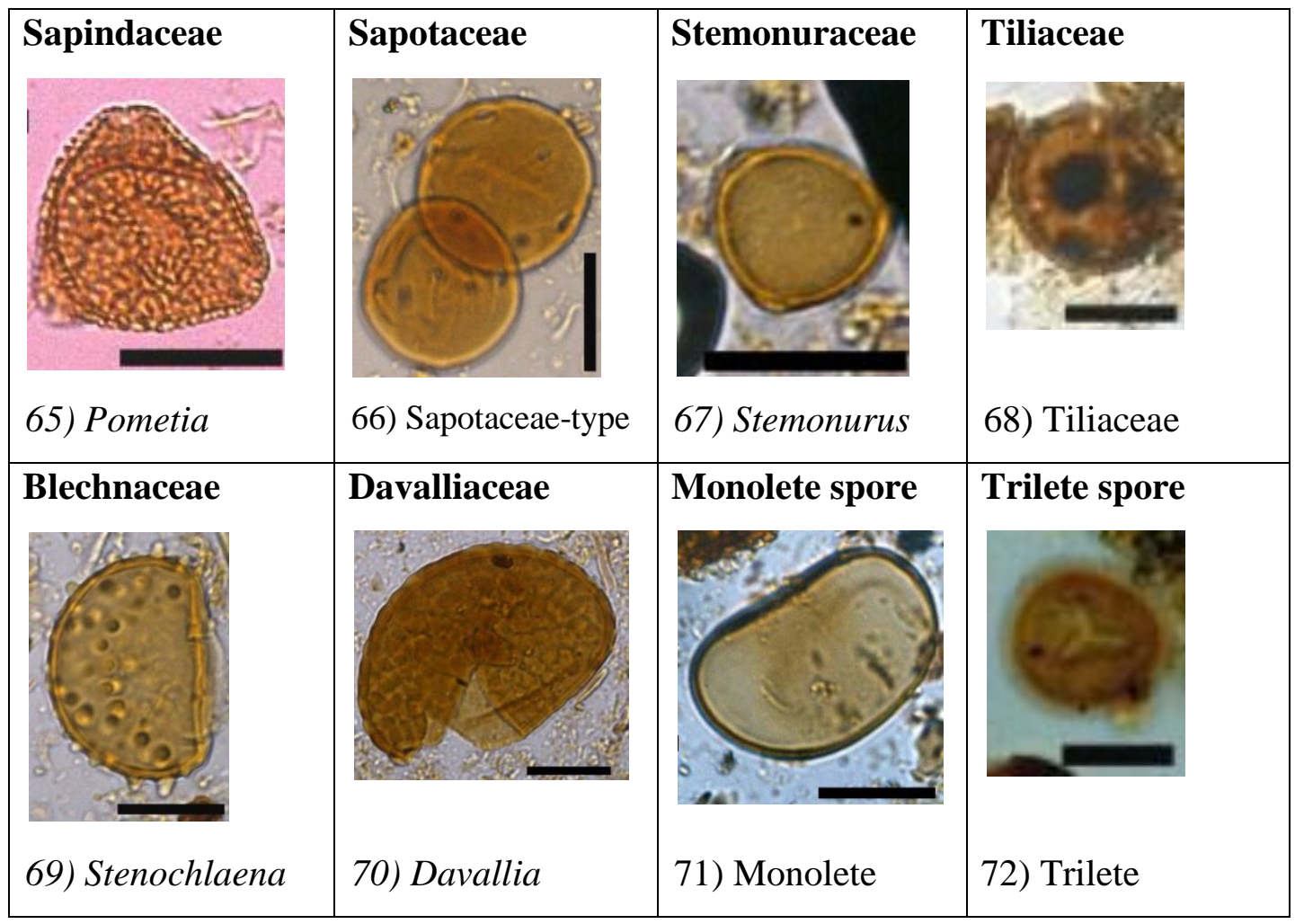

Each black bar represents $20 \mu \mathrm{m}$. 